NYPL RESEARCH LIBRARIES 


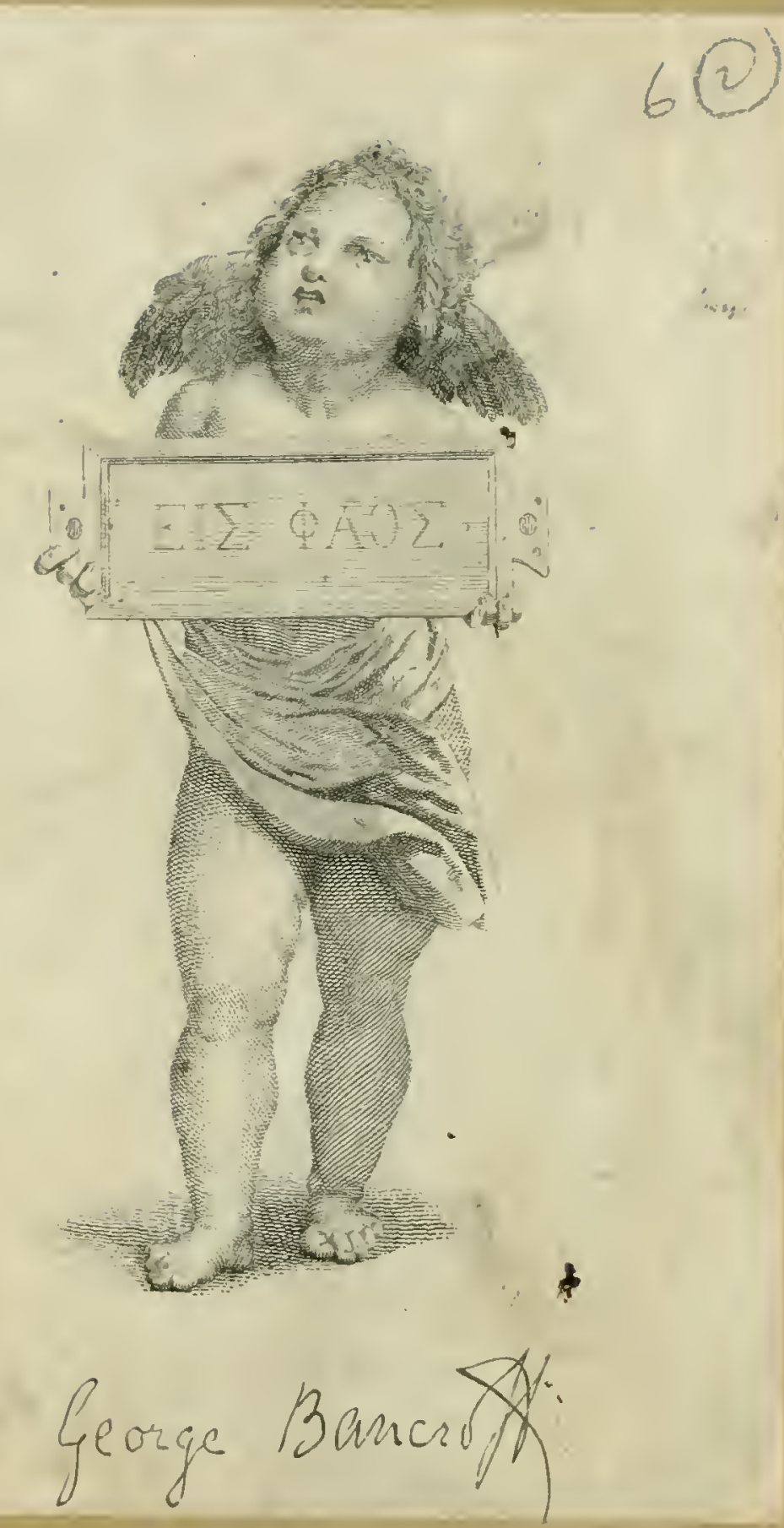


copy 2

$1-1 Q E$

Wh KLLOMS 




\title{
NATURAL' AND CIVIL
}

\author{
HIS T O R X
}

(2):

\section{$\forall \mathbb{R} \mathbb{R} \mathbb{N} \mathbb{N}$ :}

\section{BY SAMUEL WILLIAMS, LL. D: \\ Member of the Metrorolobical Society in Germang, oe trom Philosorhical Society in Philadelphia, and of the Academy or Arts and Sciences in Massachusett?.}

\section{IN TWO VOLUMES.}

\section{$:::::::::::$ \\ VOLUME I:} $:::::::::::$

THE SECOND EDITION, CORRECIFD AND MUCH ENLARGED.

\section{BURLINGTON, VT.}

\section{PRINTED RY SAMUEL MILI.S.}

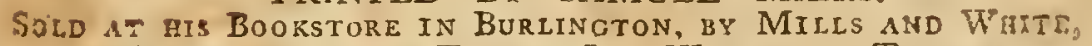
Middelebury, Isaian THOMas, Jun. Worcester, ThOMA\& AND ANDREws, Boston, THOMAS AND WHIPRE, AND

S. SAWYER anb CO. NeIVEURYPORT:' :, 


\section{DISTRICT OF VERMONT, to Tuit.}

BE it remembered, that on the twenty fifth day of Febre: ary, in the thirty third year of the Independence of the

c L. S. United States of America, Samuel Mills of Burlington in

faid District, hath deposited in this Offee, the title of a Book, the right where of he claims as proprietor, in the words following, to wit :

"The Natural and Civil History of Vernoat. By Samuel Williams, "LL. D. Member of the Meteorological Society in Germany, of the ac Philosophical Society in Philadelphia, and of the academy of arts or and Sciences in Massachusetts. In two Volumes. Volume $I$. The "second edition, corrected and much enlarged."

In conformity to the an of the Congress of the United States, enzitled " an act fur the encouragement of learning, by securing the copies of Maps, Charts and Books, to the authors and proprietors of such copies, during the times therein mentioned,"

CEPH AS SMITH, Jun.

Clerk of the Diftict of Vermont.

A true Copy of Record,

CEPHAS SMITH, Jun, Clerk.

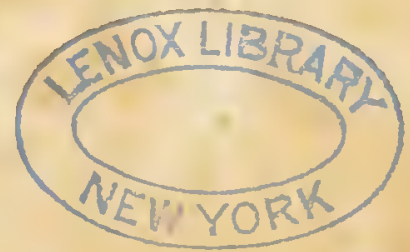


TO THE CITIZENS OF THE STATE ON VERMONT,

THE FOLLOWING OBSERVATIONS

ON THEIR

NATURAL AND CIVII

\section{HISTORY,}

ARE HUMBLY INSCRIBED;

AS A TESTIMONY OF RESPECT FOR THEIR

MANY VIRTUES,

AS AN ATTEMPT TO PROMOTE

A MORE PARTICULAR ACQUAINTANCE

WITH THEIR OWN AFFAIRS,

AND WITH THE MOST ARDENT WISHES FOR

THEIR FURTHER IMPROVEMENT

AND PROSPERITY,

BY THEIR OBEDIENT

AND HUMBLE

SERVANT,

THE AUTHOR

Rutland, July 16, 1794. 


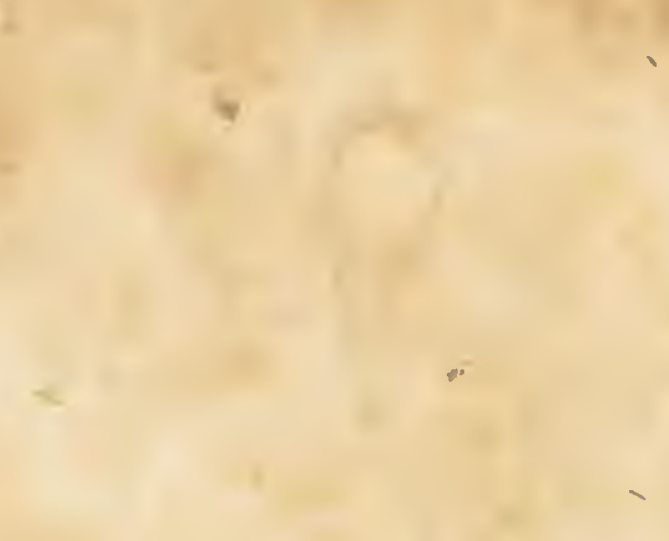




\section{PREFACE.}

THREE centuries have passed arvay since America was first discovered ly Colum. bus. From that time until now, the affairs of America have engaged the attention of historians and philosophers. The natural productions of this continent, have been one object of general inquiry. Among the Spanish writers, there are some good essays on the natural history of the southern parts of America. In Canada, some of the physicians and Jesuits were attentive to the natural productions of that part of the continent: and have left some valuable pieces on the natural history of New France. This kind of knowledge was not much attended to, by the first settlers of the British colonies; and we have but few of their ancient writings, in which it was contemplated at all. Obliged to depend upon transient and partial accounts, the best writer upon natural history, M. de Buffon, has fallen into many mistakes respecting the natural productions of $\mathrm{A}$ merica, which, more accurate ubservations would Thave corrected. The subject instead of being fully explored, is yet a treasure but little examined.

The Man of America was an object still more curious and important. But the age in which the first discoveries and settlements were made, was not enough enlighiened, to afford either accurate or impartial observations, on the manners, customs, langunge, abilities, or state of society, among the Indiaus. Prejudiced by their sordid 
manners, and enraged by their barbarities, the men of Europe never looked for any thing good in such men : And while interest and revenge joined to destroy that unhappy race, but few were able to consider their customs or rights with calmness, or dared to say any thing in their favor. It is not more than half a century, since this subject has been properly attended to by philosophers: And their conclusions have been of the most opposite and contrary kinds. Some have with greal zeal advanced, that the perfection of man was to be found in the savage state; while others have as warmly contended, that this was the lowest state of degradation and abase.. ment, to which the human race can possibly be reduced. Such opposite and contrary systems make it necessary to examine this part of the natural history of man, with great care and impartiality; that we may distinguish what was valuable in that stage of society, and what was disadvantageous and degrading.

$A_{N}$ object of still higher magnitude and importance, has been presented to our view by the American Revolution. The first settlers in the British colonies were left in a great measure by their sovereigns, to take care of themselves. The only situation which they could take, while they were clearing the woods and forming their settlements, was that of equality, industry, and ccunomy. In such a situation every thing tended to produce, and to establish the spirit of freedom. Their employments, customs, man. mers, and habits; their wants, dangers, and interests, were nearly the same; these, with every ather circumstance in their situation, operated. 


\section{PREFACE.}

with a steady and certain tendency, to preserve that equality and freedom, which nature had made. This spirit of freedom was in some degree checked by the customary interpositions of royal authority: But these were too irregular and contradictory, to become matters of venera: tion, to alter the natural feelings of men, or to change the natural course and tendency of things: And while the ministers of kings were looking into their laws and records, to decide what should be the rights of men in the colonies, na. ture was establishing a system of freedom in $A$. merica, which they could neither comprehend or discern. The American Revolution explained the business to the world, and served to confirm what nature and society had before produced.

HAVING assumed their rank among the na. tions of the earth, the states of America now prescnt to the world a new state of scciety; founded on principles, containing arrangements and producing effects, not visible in any nation before: The uncommon and increasing prosperity which has attended it, has ascertained its spirit and tendency: The people are distinguished by the spirit of inquiry, industry, economy, enterprize, and regularity: The government is dependent upon, but guides, and reverences the people: And the whole country is rapidly increasing in numbers, extent, wealth, and power. The highest perfection and felicity; which man is permitted to hope for in the present life, may rationally be expected in such a state of society: And it becomes of course the object of univer. sal inquiry and attention.

To represent the state of things in America 
in a proper light, particular accounts of each part of the federal union seem to be necessary; and would answer other valuable purposes. An able historian, the Reverend Dr. Belknap, has obli. ged the world with the history of New. Hampshire. The following treatise is designed to describe the operations of nature and society, in the adjacent state of Vermont. This is the youngest of the states, an inland country, and now rapiclly changing from a vast tract of uncultivated wilderness, to numerous and extensive settlements. Ii this stage of socicty, in. dustry and economy seem to produce the great. est effects, in the shortest periods of time.

THE manner in which the work has been ex. ccuted, I am apprehensive will require much candour in the rcader. In the variety of subjects which have come under contemplation, I cannot flatter myself, that I have beer free from crrors and mistakes: And the reason why several of the subjects are so imperfectly considered, was because I had not the ability or infor. mation to state them otherwise.

THE American war considered with respect to its causes, operations; or effects, presents to our view some of the most important events, which have taken place in modern times: But neither of these particulars can be comprehended in the history of any particular state. To give such an inperfect view of this subject as could be properly contained in the history of Vermont, did not appear eligible. No further accounts therefore of the war, are inserted, than what appeared necessary to explain the subject, which I had more particularly in view. 
THE controversies which took place between the states of Vermont, New York, and New Hanpshire, were of the most dangerous nature; and they were agitated for a while, with a vio. lence greatly unfavorable to the peace and safety of the whole union. Most of the wars which have taken, place among mankind, have been occasioned by disputes respecting territory and jurisdiction: And however just or proper it might be for any nation, to give up part of its territory and dominion to its neighbours, such a sacrifice was scarcely ever made without compulsion. and force. To have expected New York would voluntarily give up part of her territory, when the decisions of the king, and the law were in her favor, was to expect that which is never done by any sovereign or nation, while they have power to prevent it. To have expected the people of Vermont would voluntarily submit to a government, which set aside their titles to the lands which they had jurchased of the crown, and made valuable by their labours and sufferings, was to look for that, which no. penple ever ought to submit to, if it is in their power to avoid it. When the states of NewYork, New Hampshire, and Vermont, had en: gaged in a controversy of this kind, it was more agreealble to the course of human affairs to expect it would produce a civil war, than to look for so much wisclom and moderation among either of the contending parties, as to prevent it.

$I_{N}$ relating these controversies, I have felt a constant anxiety, lest I should misrepresent the proceedings of either of those states. I had not the interests or the passions which those parties vol. I. A 
produced, to guard against; nor am I appre: hensive that prejudice has misled me, in relating any of those matters. But it is not improbable that $\mathrm{I}$ have not had compleat information in some particulars, respecting those complicated controversies; and may have mistaken the views of parties, in some of their leading transactions. If this should be found to be the case, it will give me great pleasure to receive such further information, as shall enable me to correct any mistakes. Those who point out to us our errors, perform the same friendly office, as those who help us to new truths.

The most important of all our philosophical speculations, are those which relate to the histo. ry of man. In most of the productions of nature, the subject is fixed, and may always be found and viewed in the same situation. And hence a steady course of observation, serves to discover and ascertain the laws by which they are governed, and the situation they will assume in other periods of time. It is probable the ac. tions and affairs of men are subject to as regular and uniform laws, as other events : And that the same state of society will produce the same forms of government, the same manners, customs, habits, and pursuits, among different nations, in whatever part of the earth they may re. side. Monarchy, freedom, superstition, truth and all the general causes which actuate mankind, seem every where to bear the same aspect, to operate with the same kind of influence, and to produce similar effects; differing not in their nature and tendency, but only in the circum. stances and degrces, in which they influence dif. 
ferent nations. But nothing is stationary, nothing that depends upon the social state, is so unalterably fixed, but that it will change and vary with the degradation or improvement of the human race. And hence, while the nature of man remains unaltered, the state of society is per. petually changing, and the men of one age and country, in many respects appear different from those of another. And as men themselves are more or less improved, every thing that constitutes a part of the social state, will bear a different appearance among different nations, and in the same nation in different circumstances, and in different periods of time. To ascertain what there is thus peculiar and distinguishing in the state of society in the Federal Union, to explain the causes which have led to this state, to mark its effect upon human happiness, and to deduce improvement from the whole, are the most important objects which civil history can contemplate in America : And they are objects, every where more useful to men, than any refinements, distinctions, or discoveries, merely speculative.

I have wished to keep such objects in view, in considering the state of society in this part of the continent: But it is with diffidence that I submit the attempt to the view of the public. The disposition of America is to favor such at. tempts and publications, as are adapted to promote any valuable public purpose : But speculative and uscless essays cannot much engage the attention of a people, whose main object is the prosperity and improvement of their country. The public sentiment will be a just decision, among which of these, the following work ought to be placed. 


\title{
ADVERTISEMENT
}

\author{
TO THE
}

\section{SECOND EDITION.}

\section{0}

THE Booksellers have desired me to. prepare the History of Vermont for another edition. The favorable reception which the public gave to the work, has lead me to wish to make it more perfect; and my friends have suggested that it would be of use to inscrt a more particular account of the Wars, which have taken place in this part of the continent. From the earliest settlement of the English and French colonies, contests arose, which gave rise to a course of such events. 'The passage from the one country to the other, lay through lake Champlain. This circumstance rendered this part of the country the field of hostiic operations, and bloody campairns. I have endearored to collect an account of these transactions; but have not had all the adrantiges of authentic documents and public libraries, to make these researches so compleat as I wished. In making these collections, and some necessary additions to the natural and civil history of the State, the sizes of the papers increased so much beyond what I expected, that it was thought best to publish them in two volumes.

Is the narrations, the reacier will find a minuteness of dates, facts, and circumstances, not common in Furopean productions; and not very entertaining in itself. This method was 
adopted with choice, and by design. Persuaded that the American commonwealth is yet in the carly years of its infancy, and unable to compre. hend to what extent, magnitude, and dignity it may arise; the author of these sheets views the history of a particular state, rather as a collection. of facts, circumstances, and records, than as a compleat and finished historical production. The more important the United States shall become in the future periods of time, of the more importance it will be to be able to find a minute and au. thentic account of the facts, proceedings, and transactions, from whence the grand fabric arose. To collect and record such facts and proceedings, so far as they relate to this part of the country, is what I have attempted. It gave me pleasure to find that the first essay was not viewed in an unfavorable light by the people of Vermont; $*$ and I entertain the hope that what is now offered to the public, will meet with their approbation.

$$
\text { July 4, } 1807 .
$$

* Letter from the Speaker of the General Assembly, to the Author of the History of Vermont.

SrR,

$$
\text { W1 NDSOR, OCT. I2, } 1795 .
$$

THE Representatives of the People entertain a lively sense of jour polite attention, by presenting them your Naturaland Civil History. of Vermont; and of the service you have reildered your country, by adding to the republic of letters so valuable a book.

I am directed, Sir, by them to return you their thanks, with their sinecre wishes, that your labor in this work, may prove as bencficial to your. self, as it must be usefui to your fellow citizens.

I am, Sir, with grcat respect and esteem, Your most obedient servant.

The Rev. Dr. Samutr Wilians, L. L. D.

1.. R. MORRIS, Speake:. 



\section{CONTENTS.}

000000

\section{CHAPTER I.}

Situatron, Boundaries, Area, Soil, and Face of the Country.

CHAP'TER II.

Mountains....Their Direction, Altitude, Tops, Caverns, the origin of Springs and Rivers.

Page.

21

26

\section{CHAPTER III.}

Rivers and Lakes.... The Situation, Chan. nels, Intervales, Courses, Depths, and Effects of the Rivers. An account of Lake Champlain, and Memphremagog.

\section{CHAPTER IV.}

Climate....An account of the Temperature, Winds, Rain, Snow, and Weather. The change of Climate which has attended the cultivation of the Country.

\section{CHAPTER V.}

VEgETAPLEPR ODUCTIONS... Forest Trees, Esculent and Medicinal Vegetables. Remarks on the Magnitude, Number, Age, Evaporation, Emission of Air, Heat, and Effects of the Trees.

8!

\section{CHAPTER VI.}

Native Anima Ls...An account of the Quadrupeds; with observations on their Enumeration, Origin, Migration, Species, Masnitude, Disposition, and multiplying Power. The Birls, Fishes, Reptiles, and Insects. 


\section{CHAPTER VII.}

Original Inhabitants.... The Employ. Page: ments, Civil Government, System of War, Education, Manners, and Customs of the Indians; the Advantages, and Disadvantages of the Savage State.

\section{CHAPTER VIII.}

ORIGINAL INHABITANTS.... Observations on the origin of the Indians, their Antiquity, progress of Socuety; and tendency to Dissolution.

\section{CHAPTER IX.}

First Setrtements and Wars with THE INDIANS...D Discoveries and settlements in their country by the French. Origin and progress of $W^{\prime}$ ar betwean the Natives and the Europeans. Influence of the Priests. French Expeditions. Pro. ceedings of the Governor of New York. Destruction of Montreal by the Iroquoise: From the year 1535, to 1689.

CHAPTER X.

160 
Page.

reduce Canada. Proceedings at Osvegoo and Lake Ontario. Buildings'and settlement at Fort St. Frederick at Crozun Point. Capture of Fort Massachusetts. Proposed expedition agoinst Crown Point. Attempt upon the Fort at Charlestown.

\section{CHAPILR XI.}

WAR...... From the year 1750, to 1757 . Conferences at Paris. Measures of the French. Embassy and defeat of Washington. Views of the English and French colonies. Congress and plan of Union at Albany. Conncil of Generals and Governors at Alexandria. Expedition and defeat of Braddock. Success of Monckton and Winslow, in Nova Scotia. Proposed Expedition to Niagara. Proceedings of Baron Dieskau at Lake Champlain. Victory of Johnson at Lake George. Termination of the campaigns of 1755. Military arrangements of the British ministry in 1756. Capture of Oszuego by Montcalin. Inactivity of the Earl of Loudon. 339 CHAP'IER XII.

W A R....Progress and events of the War in the years 1757 and 1758. Loudon's preparations for the campaign. Montcalm's measures with the Indians. Designsupon the English. Patnam's account of Webb's proceedings. Conquest of Fort' William Henry. Savage massacre of the prisoners. Reflections on Montcalm's conduct. Result of the campaign in 1757. Change of the British conncils and ministry. vor. I. $\mathrm{B}$ 
Conquest of Louisbourg. Abercrombie's Page. attempt and defeat at Ticonderoga. Capture of fort Frontenac by Bradstreet. Of Fort Du Quesne by Forbes. Amherst assumes the command.

\section{CHAPTER XIIT.}

W AR....Progress and events of the War in the years 1759 and 1760. Plan of the campaign for 1759. Conquest of Quebec by general Wolfe. Capture of Ticonderoga and Crown Point by general Amherst. Expedition against the Indian village of St. Francois by major Rogers. Proceedings on Lake Champlain. Cap. ture of Niagara by general Johnson. Reflections on the campaign of 1759 . Measures of Vaudrieul at Montreal, in. 1760. Plan and proceedings of general. Amhorst. General Murray's defeat at Quebec, and arrival at Montreal. HaviIand's arrizal at the river St. Lawrence. Capitulation and surrender of Canada to seneral Amherst. Refiections on the origin of these Wars. Their ef,ects on. the morals, literature, population, settlement, and pulitical state of the colonics. Ais 


\section{APPENDIX.}

No. I.

An account of the variation of the Magnetic

Needle in the Eastern States.

No. II.

Observations on the change of climate in Europe and other places.

\section{No. III.}

An account of. Frogs dug out of the earth at Burlington.

\section{No. IV.}

Observations on the fascinating power of . Serpents.

\section{No. V.}

A dissertation on the colours of men, particularly on that of the Indians of America. 493

No. VI.

Garrangula's Speech. Aspecimen of Indian policy, eloquence, and manners.

\section{No. VII.}

Alomument of Lord Viscount How. in Westminster Abbey:

\section{No. VIII.}

Momument erected to the memory of General Wolf e, in Westminster Abbey.

Inscription on the tomb of the Marquis $\mathrm{D} \mathrm{E}$ Montcalm, at Queber. 
NATURAL AND CIVIL

\section{HISTORY OF VERMONT.}

\section{nanaran}

\section{CHAPTER I.}

Situation, Boundaries, Area, Soil, and Fase of the Country.

THE State of Vermont is situated between 42 degrees 44 minutes, and 45 degrees of north latitude; and between 1 degree 43 minutes, and 3 degrees 36 minutes of longitude, east from the meridian of Philadelphia. It is altogether an inland country; surrounded by the States of Newhampshire, Massachusetts, Newyork, and the Province of Canada. That part of the State of Vermont which is nearest to the sea coast, is at the distance of seventy or eighty miles, from any part of the ocean.

$\mathrm{O}_{\mathrm{N}}$ the south, Vermont is bounded by the state of Massachusetts. This line is forty one miles in length, and was a part of the divisional line between Massachusetts and Newhampshire. It was derived from the decision of a former King of Great Britain. On March 5, 1740, George the second, resolved, "That the northern boundary of the Province of Massachu. setts, be a similar curve line, pursuing the coursc of Merrimack river, at three miles distance, on the north side thereof, beginning at the Atlaritic 
occan, and ending at a point due north of $\mathrm{Pa}$ tucket fulis; and a straight line drawn thence due rest, until it meets with his Majesty's oth. ei poremments." The point three miles north of Patucket fais, was found to be in the town of Diacis. From that point, the surveyor, Richard Hazen, in the months of February and March, 1741, rain the divisional line between Irassachusetis and Nerhampshire. He was directed by Mr. Beicher, at that uime governor of both those provinces, to allow ten degrees for tine wcsterly rariation of the magnetic needle. The magnetic variation, at that time and place, was not so great, as the surreyor assum. ed : And when he arrived at Connecticut river, a distance of fifty five miles, instead of being in a west line, he had deviated to the north 2 minutes 57 seconds of latiude. This error in the direction of the line, occasions a loss of 59,873 acres to Newhampshire; and of 133,897 acres to Vemont.*

Tif eastern boundary of Vermont, is formed by the west bank of Connecticut river. This line, following the course of the rirer, is about two hundred miles; and is derived from the decree of George the third. On the 20th of July, 1764, his Majesty ordered and declared, "The western banks of the river Connecticut, from where it enter's the Prorince of Massachu. setts Buy, as fur north as the forty fifth degrec of northern latitude, to be the boundary line between the two Provinces of Newhampshire and Newyork."

'Tis north line of the State begins at the lat..

* Appendir No. I: 
itude of 45 degrees north, and runs upon that parallel, from Lake Champlain to Coinccticut river. This line is ninety miles and one quarter of a mile long, and divides this part of the United States from the Province of Canada. Much pains was taken by the Provinces of Newyork and Canada, to ascertain the latitude of 45 by astronomical observations. This was done by commissioners from both Provinces, in the month of September, 1767. At the place where the line crosses. Lake Champlain, they erected a monument of stone, which is yet standing. The line was ifterwards rum in the year 1772 by $\mathrm{I}$. Carden and I. Collins of Quebec, but with great error. By order of Governor Tichenor, in 1806, I cxamined the situation of this line in the castern part of the state. By astronomical observations I found the monument they had erected on the eastern bank of lake Memphremagog, was in the latitude of 4.4 degrees 53 minutes 46 seconds; and at Connecticut river, their monument was in the latitude of 44 degrees 47 minutes 59 seconds. Admitting their line to have been run in a straight course, this would imply an error of 8 degrees 52 minutes 19 seconds in the direction ; and occasions the loss to Vermont of 401973 and an half acres of land; erual to 17 44-100ths townships. The direction of Connecticut river is from the northeast, and on that account if the divisional line was continued on the parallel of 45 degrees till it intersected the river, one or two more townships of land would accrue to Vermont. 'This line ariseth from the proclamation of George the third, of 
October 7, 1763, determining the southern boundary of the province of Quebec ; and from the treaty of peace between Britain and the States of America, in 1783.

Beginning at the southwest corner of the town oi Pownal, the west line of Vermont runs northerly, along the western boundaries of the townships of Pownal, Bennington, Shaftsbury, Arlington, Sandgate, Rupert, Pawlet, Wells, and Poultney, as the said townships are norr held and possessed, to the river commonly called Poultney river; thence down the same, through the middle of the deepest channel thereof, to East Bay ; thence through the middle of the deepest channel of East Bay, and the waters thereof, to where the saine communicate with Lake Champlain; thence through the middle of the deepest channel of Lake Champlain, to the eastward of the islands called the Four Brothers, and to the westward of the Islands called the Grand Isle, and Long Isle, or the Two Heroes, and to the westward of the Isle la Mott, to the forty fifth degree of north latitude. This line is about one hundred and seventy miles in length ; and results from the declaration of the conmmissioners of Newyork, of October 7, 1790 ; and the concurring act of the General Assembly of the State of Vermont, passed October $28,1790$.

Computing by the latitudes, the length of the State from the southern to the northern bounda$\mathrm{ry}$, is one hundred and fifty seven miles and an half. The mean width from east to west is about sixty five miles. This will give 10,237 and an half square miles, or $6,552,000$ acres, as 
the superficial area contained within the boundaries of Vermont; but a considerable deduction must be made, to exclude the waters, and reduce it to the just quantity of land.

The land included within these limits, is of a very fertile nature, fitted for all the purposes and productions of agriculture. The soil is deep, and of a dark colour ; rich, moist, warm, and loamy. It bears corn and other kinds of grain, in large quantities, as soon as it is cleared of the wood, without any ploughing or preparation : And after the first crops, naturally turns to rich pasture or mowing.

The face of the country exhibits very different prospects. Adjoining to our rivers, we have the wide extensive plains, of a fine level country. At a small distance from them, the land rises into a collection and chain of high mountains, intersected with deep and long vallies. Descending from the mountains, the streams and rivers appear in every part of the country, and afford a plentiful supply of water. 


\section{CHAPTER II.}

Mountarns...-Their Direction, Altitude, Tops,

Caverns, the Origin of Springs and Rivers.

IN the formation of our mountains, nature has constructed her works on a large scalc ; and presents to our view objects; whose magnitude and situation, naturally engage our attention. 'Through the whole tract of country which lies between the west side of Connecticut river, and the cast sicle of Hudson's river, and Lake Champlain, there is one continued range of mountains. These mountains begin in the Province of Canada: From thence, they extend through the States of Verniont, Massa. chusetts, and Connecticut, and terminate within a few miles of the sea coast. Their general direction is from N. N. E. to S. S. W. and their extent is through a tract of country, not less than four hundred miles in length. 'They are one continued range or collection of mountains, appearing as if they were pilcd one upon another. They are generally from ten to fifteen miles in width, are much intersected with vallies, abound with springs, and streams of water, and are every where covered with woods. Their appcarance, is anong the most grand and majestic phenomena, which nature exhibits. From the perpetual verdure which they exhibit, they are called the Green Mountains; and with great propricty their name has been assigned to the Statc. 
The altitude of mountains, has been one of the curious inquiries, which the philosophers of this century have been solicitous to determine. The most common method of measuring their heights, has been by the Barometer. I do not know that in many cases, a better method could have been applied. The theory however of this, is not attended with certianty, or precision: And in its application, it has generally given very different altitudes, to the sime mountain. Gcometrical mensurations admit of greater certainty and simplicity, where they can be applied : But the difficulty and expence of making such mensurations, have prevented any great progress from being made, in this part of the natural history of the earth. In North America, the height of most of our mountains, remains yet to be deternined. In December, $1792, I$ attempted to ascertain the altisude of Kellington Peak, one of the highest of the green mountains, by a geometrical process ; and had the happiness to succed in the mensuration. The measures stood thus,

Height of 'Kellington Peak above the liect. plain at the State House in Rutland, by geometrical mensuration, _ - 2813 Height of the State House above the waters of Lake Champlain, cleduced fiom the mensuration of the falls of Oiter Creek, and a computation of other descents,

Descent of the water from that part of Lake Champlain where the current be- gins, to St. John's, a distance of nfty miles, estimated at 12 inches toamile, 
Falls betwecn St. John's and Chamble, estimated,

Descent of the water from the bason of

Chamble to Quebec, a distance of one hundred and eighty miles, estimated at twelve inches to a mile, - - 180. Admitting the waters of the river St. Law. rence at Quebec, to be of the same level as the sea, the altitude of Kellington Peak, by these measures and computations, is 3454 feet above the level of the ocean. The altitude at which a perpetual congelation takes place in this latitude ( 43 degrees 30 minutes) is about 8066 feet above the level of the sea. This is proba. bly four fifths of a mile higher than the tops of our highest mountains.* But although they. (3)

* Mount Blane in Savoy, is the highest mountain in Europe, and probably the highest in the otber hemisphere. In 1787 its altitude was found by M. de Saussure to be 15,673 English feet above the level of the sea. In the southern parts of America, M. Bouguer found the highest part of the Cordilleras, to be 20,590 feet in height ; this is the highest of any upon the globe. In Virginia, according to Mr. Jefferson, the mountains of the Blue ridge, and of these the Peaks of Otter, are thonght to be of the greatest height, measured from their base. "From data," saith he, "which may found a tolerable conjecture, we suppose the highest peak to be about 4000 feet perpendicular." (Notes on Virginia, Phila. Edit. p. I8.) The white mountains in the northeasterly part of Newhampshire, are generally estecmed to be the highest lands in Newengland. Their altitude has not been determined by geometrical mensuration, but there is one circumstance attending their phenomena, which may serve to denote tbeir altitude, with much probability. From the observations which have been made of their tops, it appears that the altitude of the highest of the white mountains, is below the point of perpetual congelation. On June 19, 1774, on the south side, in one of thic gullies, the snow was five feet deep. On Scptember 1, 1783, the top of the mountain was covered with ice and snow, newly formed. In 1784 , snow was seen on the south side of the largest mountain, until July $\mathrm{I} 2 \mathrm{th}$. In I 790, the snow lay until the month of August. In general, the mount:in begins to be covered with snow as carly as September; but it goes off again, and seldom becomes fixed until the end of October, or the beginning of November: But from that time, it remains until July. (Belknap's Hist. Newhampshire, 3.46,47.) From these obscrvations it is apparent, that the white mountains rise nearly to the line of perpetual congelation in that latitude, but do not fully come up to it. These mountains are in the latitude of 44 degrees 5 minutes north. The line of perpetual eongelation in that latitude, as deduced from the observations which have beex 


\section{HISTORY OF VERMONT.}

are far below the freezing point in summer; their phenomena and productions are very much affected by the degree of cold; to which they are constantly exposed.

THE tops of our mountains are generally composed of rocks, covered over with moss: The trees appear to be very aged, but they are of a small size ; and all of them are of the species called evergrcens ; pine, spruce, hemlock and fir ; intermixed with shrubs and bushes. The powers of vegetation regularly diminish, as we approach the summit of an ligh mountain ; the trees degerierate in their dimensions, and frequently terminate in a shrubbery of spruce and hemlock, two or three feet high; whose branches are so interwoven and knit together, as to prevent our passing between them. Trees thus diminished, with shrubs and vines bearing different berries, and a species of grass called winter grass, mixed with the moss of the rocks, are all the vegetable productions, which nature brings forth on the tops of our highest mountains.

$T_{H E}$ sides of our mountains are generally very irregular, and rough; and some of them appear to have large apertures, or openings among the rocks. Among these subterraneous passages, some caverns of a considerable extent have been found. One of these is at Clarendon, on the southeast side of a mountain, in the

made in Europe, is 7872 feet above the level of the sea. From the greater coldness of the American climate, the point of perpetual congelation in a similar American latitude, cannot exceed, but must ratlier fail something short of this. The altitude therefore of the white mountains, cannot be estimated as more than 7800 feet above the level of the ocean; and this is prabably the altitnde of the highest mountainsia: the eastern states. 
wesierly part of the town. The mouth of the cave is not more than two and an half feet in diameter. In its descent, the passage makes an angle with the horizon of 35 or 40 degrees; but continues of nearly the same diameter, through the whole length, which is thirty one feet and an half...-At that distance from the mouth, it opens into a spacious room ; twenty feet long, twelve feet and an half wide, and eighteen or twenty feet high. Every part of the floor, sides, and roof of this room, appear to be a solid rock, but very rough and uneven. The water is continually percolating through the top, and has formed stalactites of various forms; many of which are conical, and some have the appearance of massive columns...-At the north part of this room, there is another aperture of about forty inches diameter, very rough and uneven. This aperture is the beginning of another passage, through the internal parts of a solid rock : The direction of this passage is oblique, and full of stops or notches, and its length about twenty four feet. Descending through this aperture, another spacious room opens to vicw. The dimensions of this apart. ment are twenty feet in width, thirty in length, and twenty in height. In the spring of the year, the whole of this lower room is full of water; and at ali other seasons, water is to be found in the lower parts of it.-.-No animal has been found to reside in this cave, and it evidently appears to be the production of nature, untouched by the hand of man.-.-Another of these cavcrns is at Danby, and a third at Dorset. These are said to be more curious than this at Claren. 
don, but they have not been properly explored. There are others in different parts of the state: All of them are the genuine productions of nature; never altered by art, and never inhabited by any of the human race.

ONE of the most curious and important operations which nature carries on in the mountains, is the formation of springs and rivers. All our streams of water in Vermont, have their rise among the green mountains: From a number of these uniting, are formed all those brooks and rivers, which run in different directions through the various parts of the country : And in general, the origin of rivers is to be found in the mountains, or high lands. In what manner do the mountains serve to produce these effects? And whence is it, that the highest mountains attract, collect, become the reservoirs, the receptacles, or the source, of the largest and most constant collections of water? One part of this effect, seems to be derived from the constint ascent of the waters, from the bowels to the surface of the earth. 'That vrater is contained in large quantities in the bowels of the earth, is evident from the springs which are found in almost all declivities; and from those which every where supply wells, at the depth of twenty or thirty feet from the surface of the earth. That these waters are constantly ascending towards the surface of the earth, and going off into the atmosphere, is evident from the evaporation which is constantly taking place, and from the manner in which heat, or as it is generally expressed, a drought affects both the surface of the earth, and the springs, by raising and dissi- 
pating the water from both. If this ascent of the waters be obstructed by any strata of clay, rocks, or any other substance, through which they cannot pașs, they will collect in such quantities, as to form or find for themselves a channel, through which they may be discharged. The place of this discharge can only be on the side of a hill, or in some ground below the levcl of that place, where they are thus collected : And at such a place the waters would continue to issue out, as long as they continued to ascend, whatever might be the severity or duration of a drought. In some such way, it appears probable to me, that some of the springs are formed in the mountains, by waters which are asccnding towards the surface of the earth ; but which, instead of going off at the top, have their discharge in small quantities, at the sides of the mountains. Any strata of clay, rocks, or of any other matter, which would retain the water when it descends in rain or dew, and produce a spring from their descent, would also prevent the ascending water from passing thro' them, and might produce a spring from their ascent. This ascent of the waters from the bowels to the surface of the carth, is a constant, powerful, and unceasing operation of nature : And secms to be the only cause, which is ade.quate to the formation of those springs, which are peremial. Such springs could scarcely be formed, or preserved, by the waters which descend in rain, because they are so little affected in the severest droughts : In these seasons, instead of being replenished by rain, the earth to the deptly of many feet, is much exhausted of 
its water by heat. And no rain can ever fall upon the surface of the earth, which was not first carricd off from it, by evaporation.

Movn TAIns serve also to form small streams and rivulets, by preventing the evaporation of water from their surfaces. The vapours out of which the clouds and rains are formed, are all of them first raised from the surface of the earth. When the evaporation is in an open field, exposed to the sun and wind, the exhalations are soon carried off into the atmosphere, and the surface of the earth is left dry. When the evaroration is trom lands covered over with thick trees and bushes, the influence of the sun and winds are much prevented; and the waters stagnate upon the surface of the earth, and render it wet and miry, in the form of swamps, and confined waters. When the evaporation is from the sides and tops of mountains, covered. with vegetubles, the waters are but slowly carried off by the heat and wind; nor can they stagnate, but will be gradually and constantly descending down the sides of the mountains, in natural or artificial channels: And in this way, the mountains will also be constantly producing small streams or rivulets.

A similar effect will also be produced by the condensation and collection of the vapours in the atmosphere, occasioned by the height and coldness of the mountains. When the weather is fair and clear, and the atmosphere serene and pleasant in the vallies, the tops of the mountains are often obscured, and covered with a thick fog or cloud. In the cool mornings of the spring and fall, the vapours form a thick fog on 
the sides and tops of the mountains, which do not dissolve and disappear, until the sun has risen several degrees above the horizon, and the heat is considerably increased. In damp and rainy weather, the largest part of the clouds seem to collect, and dissolve upon the mountains. In winter the snows fall sooner, lie deep$\mathrm{er}$, and continuc longer on the mountains, than on any other part of the country. These phenomena denote a greater, and a more constant collection of vapours and clouds by the mountains, than takes place any where else; and it scems to be occasioned by the greater degree of cold, which prevails in those elevated situations. The highest parts of our mountains generally abound with rocks, and are covered with large quantities of thick green moss; so extensive, compact, and thick, as to reach from one rcck to another, and of so firm a contexture as to bear the weight of a man, without being broken. These immense beds of moss retain the moisture supplied by the clouds and rain : And while part of it runs down the sides of the mountains, part will be detained by the spungy surface, to penetrate and sink into the earth. On this account, and for want of a more rapid evaporation, several of our mountains are constantly wet on their tops, and have marshy spots, which are frequented by the aquatic birds. The roads over these mountains are fiequently very wet and miry, when the valleys below are diry. When the waters thus supplied by the clouds and rain, meet with any strata winch prevent their descent, they collect in such quantities as to form a channel, and issue out 
at the sides of the mountain in the form of springs and rivulets. All those springs, which are intermitting, seem to be thus formed by the rains, or descending waters: And the more constant and regular the rains are, the more permanent and steady will these springs be : Such kinds of intermitting springs are to be found in great numbers, on the sides of all high mountains. They never fail to run while the rains continue in their usual quantities; but when the rains cease, and a severe drought comes on, these springs are always found to fail.

In each of these ways, the mountains supply water for the springs and streams, out of which, the rivers are formed: And they are such as can never fail, while the present cconomy of nature shall subsist. But as the country becomes cultivated, some of the smaller streams must decrease; and it is not improbable that when the woods shall be cut down, some of the. lesser springs will wholiy disappear.

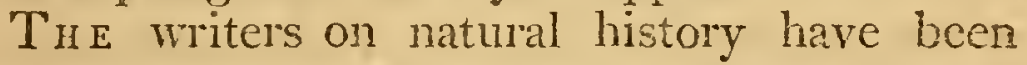
much divided in their opinions respecting the origin of springs and rivers. M. De La Hire contends that the water from which the rivers are supplied, must be derived from the sea, and raised through the pores of the earth : 'That no: other source would be sufficient to produce. those immense streams, that constantly appear in the form of brooks and rivers ; or that could supply the vast quantities that are cmployed in. vegetation, or discharged into the atmospliere. by evaporation. Hist. de l'Acad. 1713. p. 56. Dr. Hailey, on the other hand, has said much to show that the vapors which are exhaled from 
the sea, and driven upon the lands by the winds; and return in the form of rains, are more thais sufficient to supply the earth with all the water that it needs; and to form the fountains, springs, and rivers, which are perpetually discharging themselves into the ocean. Phil. Trans. Vol. 2. p. 128.

Borm these theories agree in deriving the water originally from the sea; nor does there seem much difficulty in admitting the principle of either: The former seems most naturally to account for those perennial springs, which never fail when the rains have ceased for months; and the latter serves to explain the cause of those, which are temporary, or intermitting:

Is the plains, hills, and mountains in this part of the continent, there is scarcely a place in which water may not be found at the depth. of thirty or forty feet from the surface of the earth; nor does there appear to be any more difficulty to have a well with permanent water, in the one than in the other of these situations. It must therefore be admitted as a well established fact, that the earth at that depth is well saturrated with water; nor does it fail, nor is the temperature of the earth at that depth much affected, in the hottest, or in the dryest season that we ever have. It may be presumed therefore that the effect of the solar heat, and the eraporation produced by it, does not extend. much below that depth; and that every where below, the earth is saturrated with water by the attraction or affinity that takes place betweeni the particles of the one and those of the other. IT is customary with the farmers in the 
New England states to avail themselves of this process of nature, and to form a perennial spring for their own convenience. The method of proceeding is this, on the side of a hill they dig a well, till they come to a sufficient quantity of water, generally from eighteen to forty feet below the surface. A passage is then dug from the botiom of the well to the side of the hill, that the water may find a regular discharge through the artificial channel, when it is received and retained in troughs or other receptacles for the use of thcir cattle. In this way artificial springs are often formed, which do not fail in our dryest summers, but become perennial, and are in every respect as permanent and useful as those which are formed by nature. From whence is the water clerived that supplies these artificial perennial springs? Not certainly from rains and shower's; which are casual, accidental, and variable; but from waters which are always in the earth at that depth, and lie too far beneath the surface to be much affected by rain or drought.

IF in this way we are able to form artificial perennial springs, is it to be much doubted but that nature does the same in a much more extensive and perfect manner? And would not this be always the effect, when the water in our hills and mountains can find or force for itself a passage, at the side or bottom of the declivity ? The phenomena seem to denote such operations and effects. In all our mountains perennial springs are found issuing at their sides or bottoms. In our most extensive and sandy plains perennial springs are often found at the bottom E. 
of their declivities. These springs continue, when the whole plain for many miles round is so parched and burnt up with drought, that ve. getation almost ceases. Could these springs be supplied with water derived from rain, when it has ceased for months; or has not been enough to preserve the vegetables from pcrishing? From what other source then could they be supplied, but from the water which is permanently and plentifully in the bowels of the earth, and is not dissipated or wasted by evaporation or heat? 


\section{CHAPTER III.}

Rivers AND IAKes...-The Situation, Chaxinels, Intervales, Courses, Depths, and Effects of the Rivers. An account of Lake Cham. plain, and Memphremagog.

ALL the streams and rivers of Vermont, have their origin among the green mountains. About thirty five of them have an easterly direction, and fall into Connecticut river. About twenty five run westerly, and discharge themselves into Lake Champlain: Two or three, running in the same direction, fall into $\mathrm{Hud}$. son's river. In the northeasterly parts of the state, there are four or five streams which have a northerly direction, and run into the lake Memphremagog; from thence, through the river St. Francis, they are emptied into the riv. er St. Lawrence.

THE most considerable streams on the west side of the green mountains, are Otter creek, Onion river, the river Lamoille, and Michiscoui.... Otter creek rises in Bromley; runs northerly about ninety miles, and falls into Lake Champlain at Ferrisburgh; and in its course receives about fifteen smaller streams. There are large falls in this river at Rutland, Pittsford; Middlebury, and Vergennes. Between these falls, the current is very slow, the water is deep, and it is navigable for the largest boats. Vessels of any burden may come up to the falls at Vergennes, five miles from its mouth. The head of this river in Bromley is not more 
than thirty feet from the head of Batton Kill, which runs in a contrary direction, and falls into Hudson's river.

ONION river, was formerly called the French river, and by the Indians, Winooski. It rises in Cabot, about fourteen miles to the west of Connecticut river, and thirty miles to the east of the heights of the green mountains. A small southerly branch rises in Washington and Corinth, not more than ten miles from Connecticut river. From this southerly branch, Onion river runs northwesterly, about seventy five miles, and cmpties itsclf into Lake Champlain, between Burlington and Colchester. This river receives fourteen smaller streams, and is navigable for small vessels, five miles from its mouth. It has several falls, between which it is navigable for boats. At one of these falls in Waterbury, the channel of the river becomes. very narrow, and passes between a high ledge. of rocks on each side. A huge unshapely rock; in some ancient time, hath fallen from one of these ledges, in such a manner, that the whole river now runs under it. The rock forms a kind of natural bridge, but one that can never be of any use ; as neither the shape of the rock, or the situation of the adjacent banks, will cver admit of a road either to, or over the rock. About six miles from its mouth, between Burlington and Colchester, the channel of this riv$\mathrm{er}$ is formed by a solid rock. The channel through the rock, by estimation, is fiftecn rods in length, fifty feet wide, and seventy feet deep. Every appearance seems to denote that this channel was formed by the water, which in this 
place could not have had any other passage... Onion river is one of the finest streams in Vermont. It runs through a most fertile country, the produce of which for several miles on each side of the river, is brought down to the Lake at Burlington. It was along this river, that the Indians formerly travelled from Canada, when they made their attacks upon the frontier settlements on Connecticut river.

The river Lamoille proceeds from a pond in Glover. Its general course is westerly : After running about seventy five miles, and receiving fourteen lesser streams, it falls into Lake Champlain at Colchester, five miles north of the mouth of Onion river ; and is of the same magnitude as that. The river Lamoille is a fine, smooth, and pleasant stream; and runs through a rich, level, fertile, country. The height of the land in the northeast part of the state, seems to be about Greenborough. About six miles to the southwest of the origin of the river Lamoille, is Scotland pond: From this proceeds Black river, which, for five or six miles runs in a direction opposite to, and nearly parallel, with that of the river Lamoille, and discharges itself into the lake Memphremagog.

Michiscour is the Indian name of the most northerly river in the state. It has its source in Belvidere, and runs nearly northeast until it has crossed the north line of Vermont : After running to some distance in Canada, it turns west, and then southerly, and then reenters the state in Richford ; and falls into Lake Champlain at Michiscoui bay, in Highgate. This river is navigable for the largest boats to the 
falls at Swanton, seven miles from its moutl. Michiscoui, Lamoille, and Onion river, are nearly of the same magnitude.

$\mathrm{O}_{\mathrm{N}}$ the east side of the green mountains, the rivers are not so large as those on the west, but they are more numerous. The largest of them are Wantastitquek or West river, White river, and Poousoomsuck. Wantastitquek has its main source in Bromley, about three miles southeast from the head of Otter creek. Its course is to the southeast; it receives seven or eight smaller streams; and after running about thirty seven miles, falls into Connecticut river at Brattleborough. At its mouth this river is about fifteen rods wide, and ten or twelve feet decp.

Try north branch of White river, rises in Kingston. The south branch has is source in Philadelphia. From Kingston, the general course of this river is southerly; its length a. bout fifty miles; it receives six or seven lesser streams; and falls into Connecticut river at Hartford. White river abounds with falls and rapids; at its mouth it is about eighteen rods in width, but not more than ter feet in depth.

Poousoomsucr, rises from: a pond in Westmore. Its course is southerly; it is made up of ten lesser streams; and after running about forty five miles, it joins Connecticut river in Barnet. It is there twelve rods wide, and eight feet deep.

Connectucut river, into which these streams fall, forms the eastern boundary of the state. The original Indian name, which it still 
bears, signifies the long river.** This river has its source in a ridge of mountains, which extend northeasterly to the gulph of St. Lawrence. "The head of its northwestern branch, is about twenty five miles beyond the latitude of forty live degrees; and so far it has been surveyed. When it first enters the state, it is about ten rods wide; and in the course of sixty miles increases in its width to twenty four rods. Its course between Vermont and Newhampshire, a distance of two hundrerl miles, is southwesterly; from thence to its mouth, the course is more. southerly. After running about four hundred miles through the country, and receiving a great number of other streams and rivers, it discharges itself into the ocean at Scabrook... With respect to its length, utility, and bearity; this is one of the finest vivers ir the eastern states. In the months of April or May, it overflows its banks; and for a length of three hundred miles, forms and fertilizes a vast tract of rich meadow. Vessels of eighty or one hindred tons, go up this river as far as Hartford in Connecticut, fifty miles from its mouth. It is navigable for boats, three hundred miles further, except the falls which the states of Vermont, Massachusetts, and Connecticut, are now making navigable by locks. While it increases the richness, and serves to transport the produce, by its perpetual majestic movement through an

* The names which the original inhabitants assigned to our moun. tains, plains, and valleys, are mostly lost. Many of our rivers, bays, and falls of water, are yet known by their ancient Indian names. On account of their originality, antiquity, signification, singularity, and sound, these names ought to be carefully preserved. In every respece they are far preferable to the unmeaning application, and constant repetition of ap improper Englisb name. 
immense tract of country, it is always adding beauty and grandeur to the prospect.

To this account of our rivers, some observations may be added respecting their operations and effects...-Their first operation scems to have been, to form themselves a channel. The highest waters descend along the mountains, until they meet with some obstacle to obstruct their motion. Whatever this obstacle may be, it operates as a dam, and serves to collect the waters into a small pond or lake. Two causes are constantly raising the waters, in such collections : The earth is perpetually brought down by the waters, to the bottom of such ponds: and the water is constantly rising by its own accumulation. When it is raised above the banks, the waters find their passage in the lowest part, and begin to form a channel there; and a channel thius formed, will constantly be made more and more deep, by the perpetual running of the water. A similar operation must take place through the whole course of the river, from its first rise and source, to its final discharge into the waters of the ocean. Their channels must at first have been formed by their waters ; which, constantly accumulating, and struggling for a passage, approach, or dis.. charge themselves into the nearest situation they cotild take to the centre of the earth.

IN this descent and passage to the ocean, all the large rivers in this part of America, have also formed large tracts of intervale lands. By intervales we mean those low lands, which are adjacent to the rivers, and are frequently overfowed by them in the spring and fall, or whenev. 
er the waters are raised to their greatest height. These intervales are level, and extensive plains; of the same altitude as the banks of the river; in width they often reach from a quarter of a mile, to a mile and an half, sometimes on one, and sometimes on both sides of the river. There are frequently two strata of the intervales, the one four or five feet higher than the other; the highest of which is not overflowed, but when the waters are raised to an uncommon height; but they are level, and extensive like the other. Both of them have many indications, that they were formed by the waters of the rivcrs. The soil is always of that rich mud and slime, which is brought down by the rivers in the spring. In digging into these lands, various appearances of decaying vegetables are frequently found. The strata formed at particular years, are easily distinguished ; and the original and new made soil are so different, as to be readily known. The limbs and trunks of large and sound trees, are often found at various depths; sometimes so low as forty feet below the surface. The small islands in these intervales, are of a different soil, and less rich ; and are evidently the tops of small hills, which have not been covered by the inundations of the rivers. These long and level surfaces are peculi. ar to the banks of rivers, and consist of the same rich manure which is yet annually brought down, and deposited by the waters. The cause; by which they are now annually increased, could not fail to have produced such effects, in the course of a long series of years.

IN these intervales there are several places, Fi 
Where another curious phenomenon occurs. The rivers have changed their courses, their anciont chamels are left dry, and they have formed new oncs. In the nicultivated parte of the country, where the operations of nature have not bien atend ur changul, the traveller finds many places where the rivers formerly rolled, which are now dry, and at a considerable distance, sometimes a mile or n:ore from the present beds of those rivers. In some of these ancient chancls, the waters nust have run for a long number of ages; as they kave worn the surface of the stones as smooth as those, which are to be found on the sea shores. In some pilices the former channels are left dry, abound. ing with sniooth siones and rocks: In others, the channcls are converted into fonds, or overguwn with buslies or trees. Appearances of this kiid are common in all the mountainous parts of the country; and something of the same kind, is constantly taking place in most of our rivers. In all large streams, the channel is more or less afiected every year: Strips of land, one or tro rods in width, and of some miles in lergth, are often carried of in the spring; and additions are made to the banks in other places. The lands thus form d, in some places, in the course of a few years amount to several acres, and are of an uncommon richness and fertility; but they are always attended with an equal joss in some other part of the river.

THE depth of the cliane's which our rivers have formed, depends upon a variety of circumstances: The nature of the soil, the declivity of the river, the situation of the adjacent banks, 
the quantity of water, \&sc. Their channels have been formed two ways, by the wearing awn of the ground in some places, and by forming or raising the intervale lands in others; but most generally the channels of our rivers have been formed in both these ways. In large streams passing through the intervales which they huve formed, and moring with a gentle force, the dcpth of the channels appear to have a similarity, or at least a resemblance. The depth of the channels in such siluations, in sundry places in Connecticut river, Ottercreek and Onion river is forty or fifty feet beiow tinat of the adjacent banks. But the alteration in the depih of these channels, is so gradual and slow, that it has scarcely been perceptible, since the frrst setieement of the country by the English.

IT is not only in the channeis and intervales, which the rivers have formed, that their effects are to be seen; but their operations are aiso visible, upon the stones and rocks. The stones which have been constantly washed by the streams are always found to be smooth and even; and the rocks in many places, are not only become smooth and slippery, but they are much worn away by the constant iunning of the water. There is another phenomenon extremely curious, derived from this cause ; in several rivers, there are holes or carities, wrought into the solid body of large rocks, by the descent, or circular motion of the water. At Rockingham, there is a remarkable fall in Connecticut river, where the water passes over a bar of solid rock ; and which it must have been constantly passing over, ever since the river 
began to flow. In the rocks at these falls, there are several cavities, which appear to have been formed by the circular motion of small stones, constantly kept in action by the force of the de. scending waters. Some of these cavities are two or three feet in diameter, and from two to four feet in depth.; and probably they are yet increasing. Such phenomena are not uncommon wherever there are decp falls in our rivers. But the most singular appearances of this nature which I have crer seen, are at Cavendish, upon Black river, near the house of Salmon Dutton. Here, the channel of the river has been worn down, one hundred feet; And rocks of very large dimensions, have been undermined, and thrown down, one upon another. Holes are wrought into the rocks, of various dimensions, and forms : Some of them are cylindrical, from one to eight feet in diamcter, and from one to fifteen feet in depth: Others are of a spherical form, from six to twenty fect diameter, worn almost perfectly smooth, into the solid body of a rock.

How long a period naturc has been employcd in carrying on these operations, we can scarcely hope to determine. All the circumstances relating to the channels of rivers, and the intervales which they have formed, are such as denote periods of time very remote, and of the highest antiquity. It can scarcely be supfrosed that in the formation of the intcrvales, the anmual increase has amounted to the tenth part of an inch. At present, the freshets in the spring and fall, and throughout the year, do not ainnually deposit the one half of this quantity of 
earth, upon the intervales. At no place in this state, is there any appearance that the surfice of the intervales has been raised an inch, in the period of ten years. But admitting such an increase, where the depth of the intervales are fifty feet, the period necessary to produce such an effect, would be six thousand years. 'But in all such kinds of computation, the data which we assume, are not marked with sufficient certainty or precision, to leave us satisfied with the conclusion, 'The effects of the rivers" upon the solid rocks, seem to be more slow, regular and uniform. There are situations in this, and in every part of America, where the water has been constantly flowing over a solid body of rock, ever since the channels of the rivers were first formed. If we knew from observation, how much such rocks were worn away in one century, by the waters, we could form a pretty just conclusion how long the waters have been running in those places. If the philosophers of the present age will make accurate observations of the altitude and situations of such rocks, and put their observations upon record in the transactions of their philosophical societies, they will enable posterity to solve a problem, which we can hardly expect to determine in our day.

WHILE the one half of our rivers pass off into the ocean to the south, through Connecticut river, the other half'find their way to the ocean, at the northeast, through Lake Champlain and the river St. Lawrence...-Lake Champlain is the largest collection of waters in this part of the United States. Reckoning its length from Fairhaven to St. John's, a course nearly 
north, it will amount to about one hund ed and fift miles. Its width is from one to eighteen miles, being very different in different, places; the mean width may be estimated at five miles. This will give one thousand square miles, or six hundred and forty thousand acres, as the area of its surface. Its depth is sufficient for the navigation of the largest vessels. It contains several islands; one of them, the Grand Isle, is twenty four miles long, and from two to four miles wide.

THE waters which form this lake, are col. lected from a large tract of country. All the strean:s, which arise in more than one half of Vermont, fow into it. There are several, which also fall into its eastern side, from the province of Canada. It is probable the rivers which flow into the west side, are as large, numerous, and extensive, as those on the east. The waters therefore, from which Lake Cham. plain is formed, seem to be collected fiom a tract of country, of a larger extent, than the whole state of Vermont.

THER $\mathrm{E}$ are many marks and indications that the surfuce of this lake, was formerly thirty or forty feet higher than it is now. The rocks in several places appear to be marked, and stained, with the former surface of the lake, many feet higher, than it has bcen, from its first discovery by Sir Samuel Champlain, in 1608. Fossil sliclls, the limbs and bodies of trees, are frequently found at the depth of fifteen or twenty feet in the carth; this is the case not only along the shores, but in the low lands at the distance of two or three miles from them. The 


\section{HISTORY OF VERMONT.}

soil in many places near the shore, is evidently of the same factitious kind, as the intervales formed by the rivers. These, and other circumstances, have left no doubt in the minds of the inhabitants along the lake shore, that the waters of it were formerly much higher, and spread to a much greater extent, than they now are.

THE operations of nature with respect to the lake, must have been the same that they were in relation to the rivers. When the waters dis: charged by the streams, amounted to such a collection, as to rise above the shores of the lake, they would overfow at the lowest part. There, the channel would begin; and being formed, it would become more and more deep, in the same manner as the channel of a river. The channel which this lake found, and formed, was to the northrard; into the river St. Lawrence; and through that into the ocean. When this channel, by the constant running of the water, was worin down thirty or forty feet, the surface of the lake would naturally subside the same space.

A $\mathrm{T}$ present there is but little alteration in the height of the waters, through the year. They generally rise from about the twentieth of April until the twentieth of June. Their rise is com. moniy from four to six feet, the greatest variation is not more than eight feet. The lake is early frozen round the shores, but it is not commonly wholly shut up with the ice, until the middle of January.* Between the sixth and the

- When the ice is become of its greategt density and firmness, large and extensive cracks or openings will suddenty take place. These cracks 
fifteenth of April, the ice generally goes off ; and it is not uncommon for many square miles of it, to disappear in one day.

THE north line of Vermont passes over the south part of the lake Memphremagog. This lake is about forty miles in length, and two or three miles wide. It lies chiefly in the Province of 'Canada, and has a northerly direction. The river St. Francis forms a communication between the lake Memphremagog, and the river St. Lawrence. Round this lake, there is a rich soil, and a fine level country.

in the ice, generally run in an oblique direction, from one Cape to anoth. er, and often to the distance of ten or fifteen miles. Sometimes the ice will separate on each side, to the distance of five or six feet; at other times it will lap over, or more commonly he thrown up in ridges four or five fcet high; and it is often broken into pieces of two or three feet diameter, all round the edges. Thisse openings often prove dangerous to the traveller. They seem to be produced, by the occasional rise and fall of the waters, in the lake; which as they cannot remove, must operate to elevatc and depress, and thus to bend and break, the extensive and solid body of ice, which must have assumed the spherical form, whicli the waters bad when they werefidst frozcn. 


\section{CHAPTER IV.}

Climate. An account of the Temperature, Winds, Rain, Snow and Weather. The change of Climate which has attended the Cultivation of the Country.

THE temperature of any particular place, depends chiefly upon the latitude, the cultivation of the country, the elevation of the place above the adjacent lands, and its proxim. ity to the ocean. The latitude of Vermont is between 42 degrees 4.4 minutes, and 45 degrees north. Much the largest part of the state has never been cultivated. A large part of the land, is a range of mountains, much higher than the adjacent parts of the country: And the state is from eighty to one hundred and sixty miles from the ocean.

THE most common method of determining: the mean degree of heat which prevails in any part of the earth, is by thermometrical observations. In the years $1789,90,91$, I made a course of meteorological observations at Rutland, about the latitude of 43 degrees, $36 \mathrm{~min}$ utes. The greatest height of Farenheit's thermometer during that period, was 93 and a. half degrees, on July 13, 1791. The least height was 27 below 0, on December 19, 1790. 'These may be esteemed as near the extremes of heat and cold, in this climate. The mean heat, deduced from the whole number of observations, was 43 and a half degres.

Tн в temperature of the climate may also be 
determined by observations of the heat which prevails in deep wells and springs. The heat of the atmosphere, is derived from the heat, which rakes place at the surface of the earth. In passing through the atmosphere, the solar rays do not communicate any heat to the particles of air. The rays must first fall upon the earth, be stopped, and collected, before they produce their effect : And no greater heat can ever be communicated to the atmosphere, than was first communicated to the surface of the earth. Hence we find the temperature of those wells and springs, which are so far bencath the surface of the earth, as not to be much affected by the heat in summer, or by the cold in winter, is the same as the mean temperature of that climate; or the mean heat of the atmosphere; in that place. The temperature of the water in the deep wells in this place, is exactly the same as the mean heat of the atmosphere. I have. repeatedly cxamined the temperature of the water in a well near the State House, by estimation forty five feet in depth, and I have always found the heat to be 4.3 and a half degrees, without any variation in summer or winter.*

* On a Journey from the University at Newhaven in Connecticut, to Burlington upon Onion river, I made the following observations upon the temperatu re of the wells; which may serve to show in what manner the beat decre afes, as we advance towards the north, in a country but little cuitivated.

Place.

Newbaven, Middletown Hartford,

Stockbridge,

Pittsfield,

Tinmouth,

Rutland

Hurlington,
Prcsident's well, Goodwin's Inn, Bull's Inn, Judge Ed wards's, Strong's Inn, Judge Mattock's Spring, Buell's Inn, Keyes' Inn,

\begin{tabular}{|c|c|}
\hline Deotil by ce- & \\
\hline $\begin{array}{l}\text { Weptiu by es- } \\
\text { timation. }\end{array}$ & $\begin{array}{l}\text { ture. } \\
\text { turetas }\end{array}$ \\
\hline $\begin{array}{l}30 \text { Feet. } \\
27\end{array}$ & $\begin{array}{l}49^{\circ} 1-2 \\
50^{\circ}\end{array}$ \\
\hline 40 & $49 \mathrm{I}-=$ \\
\hline 25 & 50 \\
\hline 40 & $\begin{array}{l}47 I-2 \\
44\end{array}$ \\
\hline $\begin{array}{l}45 \\
25\end{array}$ & $431-2$ \\
\hline
\end{tabular}


ANOTHER view of the climate may be taken from the common operations of nature, the vegetable and animal productions. The times when the trees and plants put forth their buds, leaves, flowers and fruit, or when the different seeds are planted, spring up, are in blossom, produce their fruit, and are gathered in ; when the birds of passage, or other migratory animals, make their approach or departure. Observations upon such phenomena, are among the best observations we can ever have, to ascertain the relative temperatures of different climates. Rẹferring those which relate to the migration of animals, to the description of the birds, one or two small tables will serve to give us a view of the times, when different vegetables produce their fruit, in this part of the continent.

$$
\text { 'TABLE I. }
$$

A view of the Climate, taken from the state of

Vegetation in the'Trees and Shrubs.

Trees and Shrubs.

Elder,

Gooseberry,

Curint,

Raspberry,

Suawbersy,

Wild Cherry,

wild Plumb,

Apple Tree,

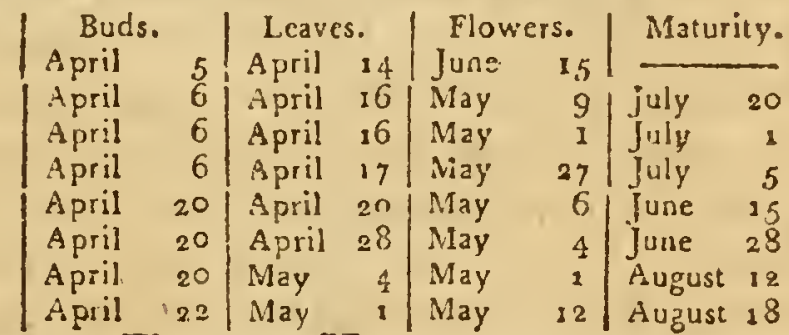

IABLE II.

$A$ views of the Climate, taken from the fruts of the Field.

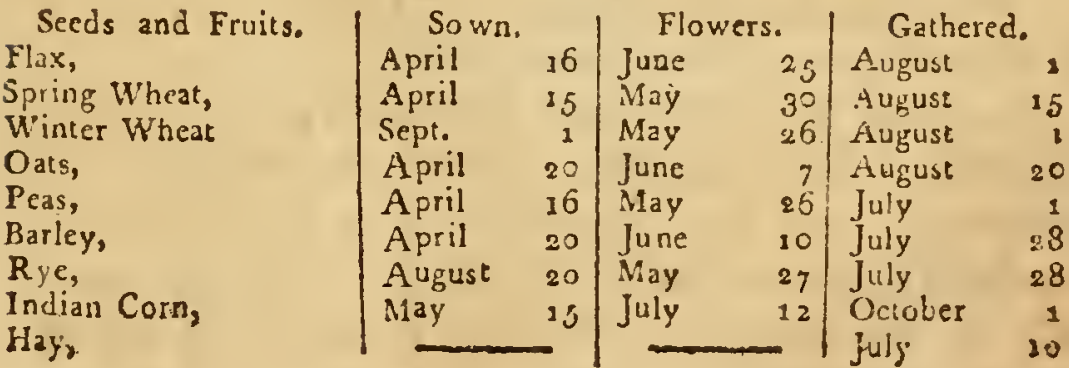


Tre frosts, commonly cease about the be. ginning of June, and come on again between the first and the middle of September. When they first come, they appear not on the hills, or lighest parts of the trces, but in the low and wet lands, and on the lowest parts of the trees. When a fog lics along the low lands adjoining. to a river, when the winds are high, and when the lands are but partly or newly cleared, the frosts are retarded or prevented; and clo not appear so soon, or so great, as in clear, low, and wet places. These circumstances seem to explain the reason why the frosts are first seen not on the high, but on the low lands. The ders and vapours are the most dense and abundant, in those places; much more so than they are at higher altitudes, or upon the hills. The first effects of the frost are not sufficient to freeze the leaves of the trees, or other regetables. The cold at first avails only to effect the congelation of the dew and rapour; as these are chicfly to be found in the low and moist lands, and not higlier than the lowest limbs of the trecs, these are the places where the first effects of the frosts appear. A high wind serres to prevent these effects, by carrying of the dew and vapours; and a fog detains the heat in amazing quantities, and prevents its flowing off from the surface of the eartil, either so rapidiy, or in such quantities, as to occasion a frost.

In those places where the earth is not covered with snow, the frost penetrates sevcral fect below the surface. In the winter of 1789 there was but little snow at Rutland; and the sur. face of the earth was frozen almost the wholc 
winter. On March the 19th the ground was frozen to the depth of three feet and eight inches. The ice in the lakes and stagnant waters, is generally frozen in the course of the winter, about thirty inches thick ; in the rivers and streams it is about twenty four ; and commonly goes off the last week in March.

THE severest cold of our winters never kills any of our young trees, and seldom freezes any of our young cattle, although they are not housed during the winter. Nor is the cold so affecting to the human body, as the extremes, and sudden changes from heat to cold, on the sea coasts. From the time that the winter first sets in, until it breaks up, we have generally a settled steady cold; for the most part without any thaw, and with but a few days in which the snow melts at all. During this period we become accustomed to the weather, and every thing in our feeling, and clothing is adapted to a steady and severe cold. Such a steady,'equal temperature, is far more comfortable than those great and sudden changes which take place, where the extremes of heat and cold are frequently succeeding each other.

TII E temperature of the American climate is so different in different parts of the same state, and often in the same latitude, that it cannot be well understood, but by viewing it in its variations through the different parts of the northern continent. The following table is designed to. exhibit such a comparative view. 


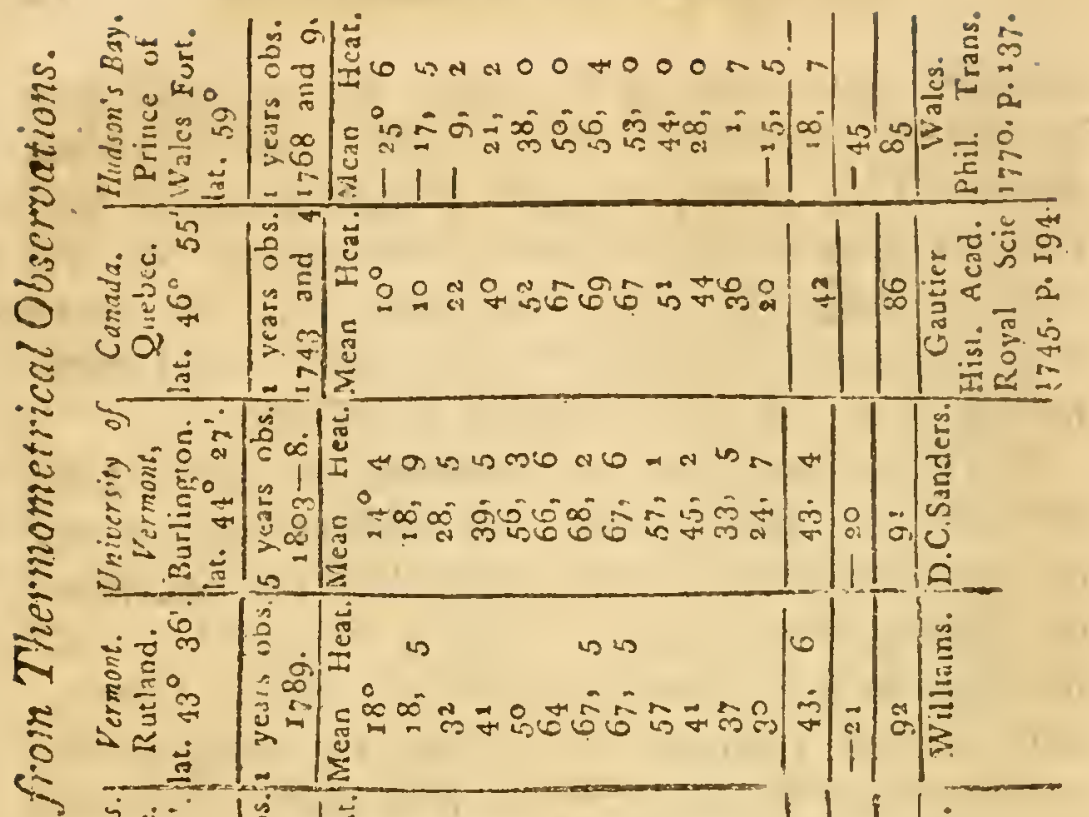

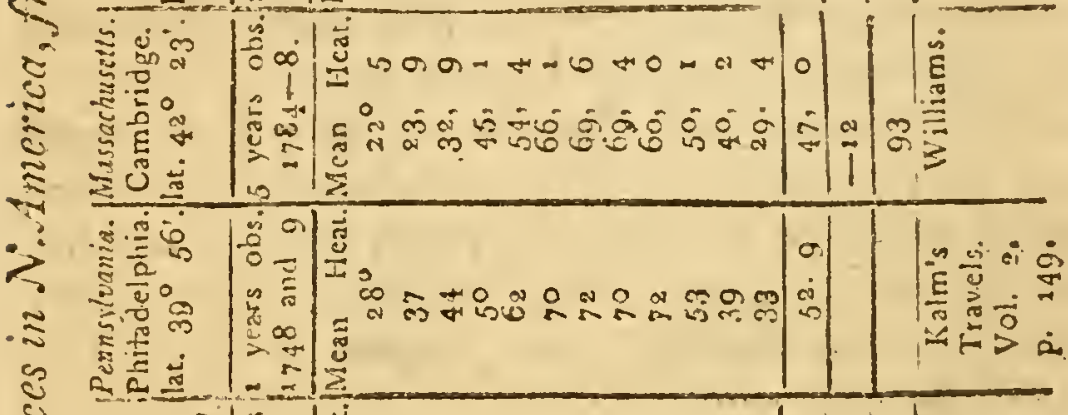

$\stackrel{2}{2}$

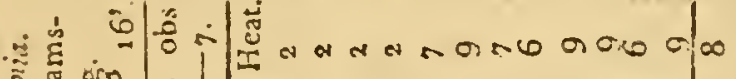

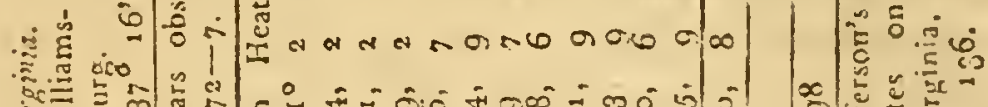

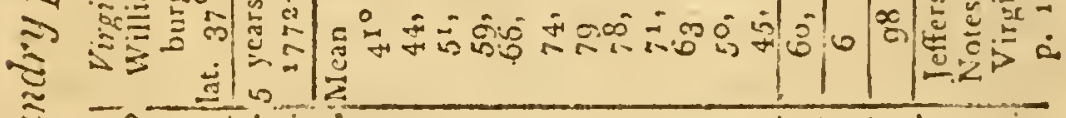

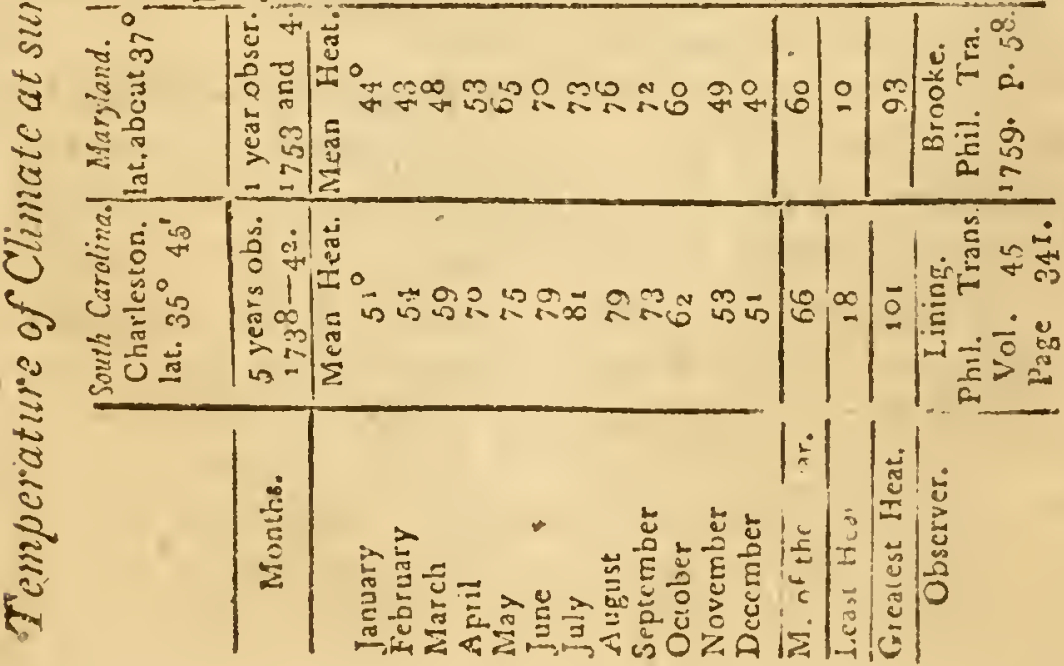


THE. winds in North America receive their sreneral direction from the situation of the sea coasts, mountains, and rivers. These are very much from the southwest to northeast. The most prevalent of our winds, are either parallel with, or perpendicular to this course; or rather, they are from the northeast, east, southwest and northwest. More than one half of the winds which blow during the year, are from that quarter which lies between the southwest and northwest. The west and northwest winds are dry, cooling and elastic. These winds always begin at the sea coast. Those from the south and soutwest are more warm, moist and relaxing. The easterly winds seldom extend so far from the sea coast as Vermont. They not only lose their distressing chill and dampress, as they advance into the country, but they seldom reach so far as Connecticut river ; and they are unknown on the west side of the green mountains. The winds seem to observe something like a regular course, during the day. At sunrise there generally seems to be a calm; about seven or eight o'clock, the wind begins to rise; which at nine or ten becones a fresh breeze; and increases until one or two o'clock : From about three or four, the wind decreases until eight or nine in the evening; when it again becomes calm, and continues thus through the night. This general routine seems to be ob. served more generally in the latter part of winter, and in the spring, than at other times of the year. But there are times in those seasons_of the year, when the wind rages without much intermission for two or three days together. 
A general table of their directions at different places upon the continent, will give the best views of their comparative courses. 


\section{HISTORY OF VERMONT.}

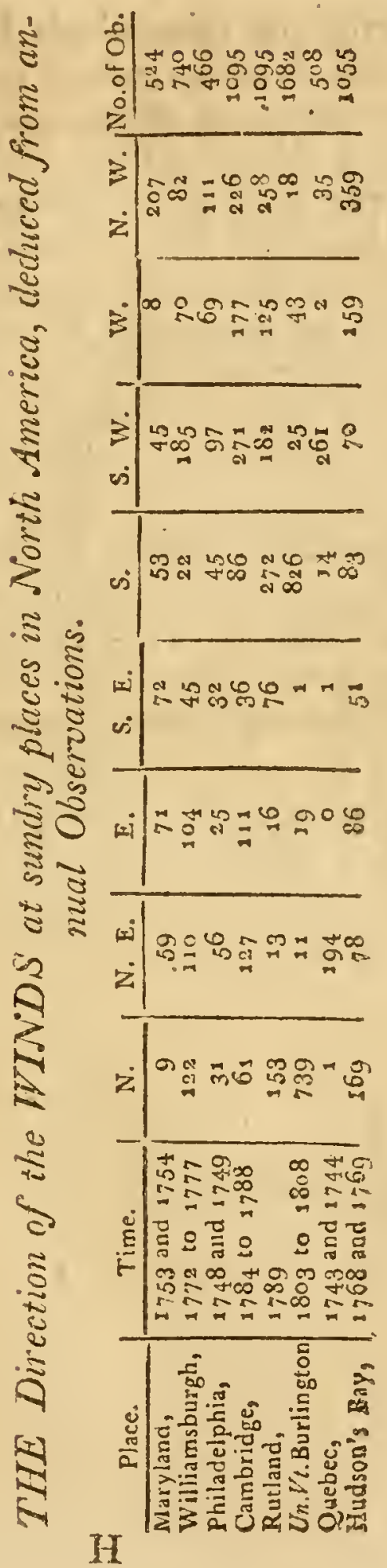


'THE quantity' of rain which falls at those places in North America where meteorological observations lave been made, has been found to be more than double to that which generally falls in the same latitude in Europe. We cannot well account for this, without supposing that the immense forests of America, supply a larger quantity of water for the formation of clouds, than the more cultivated countries of Europe. Many parts of America do however, suffer severely by drought: this is very seldom the case in Vermont. The lands are naturally moist, the mountains supply water for regular rains, and the heat of the sun is not so intense as suddenly to disperse the vapours, dry up the waters, or parch the land. These kinds of observations will be reduced to the smallest compass, and give the most complete comparative riew, by exhibiting them in the form of a gene. ral table. 


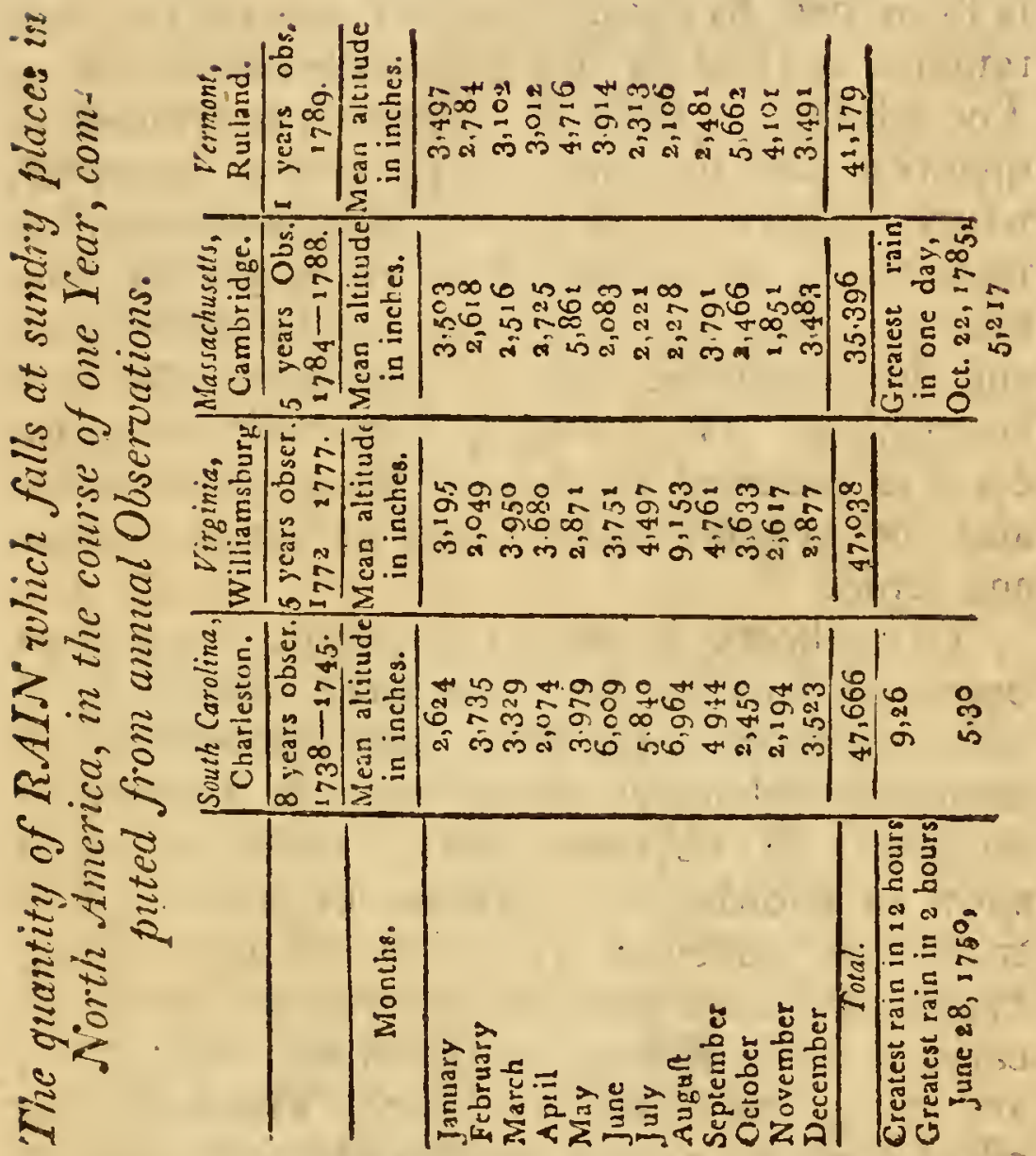


DURING three months in the year, this part of America is covered with snow. On the mountains the snow is generally from two and an half to four and an half feet deep; and does not go off until after the midclie of April. In the lower grounds, the snow for the most part, is from one, to two and an haif feet deep ; and remains until about the twentieth of March.... The advantage clerived to the earth from the quantity and duration of the snow, is every where apparent. As soon as it is melted on the mountains, the earth appears to be greatly fertilized: the spring comes on immediately ; and the vegetables of every kind are green and flourishing: With a very littie cultivation, the earth is prepared for the reception of the seed; and the regetation becomes extrenely quick and rapid.

THE effects being so apparent, a general opinion seems to have taken place, that the snow communicates to the earth some nitrous salts or enriching substance which tends to increase its fertility. In February 1791, I melted as much snow as afforded six gallons of water. The snow was collected as it was falling: Being evaporated there remained eleven grains of calcarious earth, five grains of an oily substance, and two grains of saline matter. The fertilizing effect of snow, cannot therefore be derived from any nitrous salts, which it receives or contains when it is falling through the atmosphere. Suspecting it might acquire some saline mixtures by laying on the earth, January S0, 17 s2, in an open field covered with grass, I collected 2.S much of the snow which lay next to the earth, 
as produced six gallons of water. This snow spread over an area of sixteen square feet, and had lain upon the ground fifty nine days. Upon evaporating the water there was not more saline matter, or calcarious earth, than in the former experiment; but a much larger quantity of oily substance. The oil was of a dark brown colour not inflammable, and weighed four pennyweights and nine grains, troy weight. From the former experiment, it appears that the biggest part of this oily matter accrued to the snow after it had fallen upon the earth: And to this oily substance, is probably to be imputed that dirty or sooty appearance, which the snow is generally observed to have, after it has begun to thaw. If the snow which I removed contained the same quantity of oil as that which I examined, a considerable nutriment might be preserved to the earth from this cause. The depth of the snow was thirty inches: The depth of that quantity which I collected to melt, as nearly as I could determine, was three inches. This will give two ounces, three pennyweights and cighteen grains, as the quantity of mucilaginous matter, which would have descended upon sixteen square feet of the carth, from the quantity of snow that was then upon the ground.

WHILE the snow thus prevents all waste from the surface of the earth, it performs another and more important office, that of preserving its internal heat. The internal parts of the earth through the territory of Vermont, are heated to about the forty fourth degree of Farenheit's thermometer. When the heat of the atmosphere is greater than this, a part of that 
heat will flow into the earth, and thus the heat of the earth will be increased. When the heat of the atmosphere is less than forty four degrees, the heat will flow out of the earth into the atmosphere, and in this way the internal parts of the earth will be losing their heat, or becoming colder. This is the case during the winter months; or rather, from the niddle of October, to the beginning of April. Hence the surface of the earth when exposed to the atmosphere, becomes frozen to a greater or less depth, according to the degree and duration of the cold. The snow tends very much to prevent this. By covering over the surface of the ground a considerable depth, the snow by its nature and colour, prevents the internal heat of the earth from flowing into the colder atmosphere, and the atmospliere from coming into centact with the earth. In this way while the earth is corcred with a deep snow, its heat is preserved, and the surface, in the coldest weather, is kept warm. 'To ascertain to what degree the heat of the carth was affected, by the quantity of snow that lay upon it, on January 14, 1791 (an extreme cold rinter) I (ug through the frozen surface in a plain open field, where the snow had been driven away by the wind, and found the grcund was frozen to the depth of three feet and five inches. In the woods, where the snow was three feet cleep, I found on the same day the heat of the earth, six inches below the surface, was thirty nine degrces. The surface of the earth had been frozen to this depth, before it was covered with snow. The frost was not only extracted, but the surface of the earth 
was heated seven degrees above the freezing point, in consequence of the snow with which it was covered.

'Tins will help us to account for the beneficial effects, which are derived from the snow, in all cold climates. Different degrees of heat are necessary, for the preservation and growth of different regetables. None of them will grow when they are frozen; and most of them will perish when the cold at their roots is very severe. A thick covering of snow prevents these effects. The earth is kept open, and the roots of the vegetables are preserved comparatively warm. The snow is continually melting at the surface of the earth : It moistens, and enriches the soil ; keeps off the frost and wind, and prevents all cvaporation from the surface of the earth. The earth thus prepared by heat and moisture, and a collection of all its effuvia, is in a fit state for that sudden and rapid veget. ation, which takes place in ail cold climates, immediately upon the melting of the snow.

Tне weather is generally fair in the winter; and often, with an hazy atmosphere. The snows are frequent, but they generally come in small quantities, and are over in one or two hours : They are not attended with high winds, or heavy storms; but they come from all points of the compass, except the east ; very frequently from the west, and northwest. Hail is not uncommon in the winter, but rain is not frequent. About the middle of March the spring commences. The winds and weather are then very unsettled until the beginning of April. In April and May the weather becomes mild and 
pleasant, attended with frequent showers. In the summer months the weather is generally fair, clear and settled. The winds are mostly from the south, and southwest; the heat in the middle of the day is often very uncomfortable, but the nights are almost ever cool and pleasant. From the beginning of September, until the middle of October, we have commonly the most agrecable season, with moderate westerly winds, and a clear sky. The latter part of October and November, are generally cold, wet and uncomfortable; attended with frequent rains, some snow and high winds.

THUNDER and lightning are common in the months of May, June, July and August; but seldom in the other months. The Aurora Borealis is the most common in the months of March, September and October; but it is not unusual at other times of the year. Heavy and long storms of snow, or rain, are scarcely ever known : But sudden and violent whirlwinds or hurricanes sometimes arisc, and do much damage in the fall; but we seldom receive any injury from the hail. Annual courses of meteorological observations properly reduced, will afford the most complete information of the weather, and meteors, in the diferent parts of North America. 


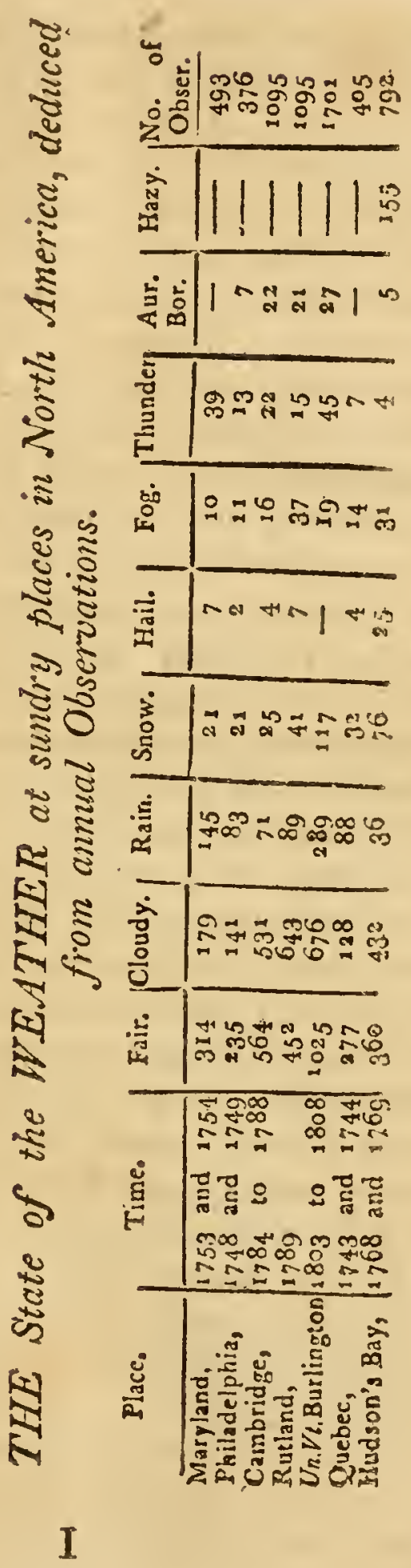


THE above accounts are designed to exhibit a just view of our climate. But instead of remaining fixed and settled, the climate is perpetually changing and altering, in all its circumstances and affections: And this change instead of being so slow and gradual, as to be a maiter of doubt, is so rapid and constant, that it is the subject of common observation and $\mathrm{ex}$ perience. It has been observed in - every part of the United States; but is most of all sensible and apparent in a new country, which is suddenly changing from a state of rast uncultivated wilderness, to that of numerous settlements, and extensive improvements. When the settlers move into a new township, their first business is to cut down the trees, clear up the lands, and sow them with grain. "The earth is no sooner laid open to the influcnce of the sun and winds, than the effects of cultivation begin to appear. 'The surface of the earth becomes more zuarm and dry. As the settlements increase, these effects become more general and extensive : the cold decreases, the earth and air become more warm; and the whole temperature of the climate, becomes more equal, uniform and moderate. At the same time the lands and roads become more dry and hard: the stagnant waters disappcar, small streams and rivulets clry up, and the redundant waters are carried off. The number and quantity of the snows decrease; the winds receive new directions, and the weather and seasons become much altered. These changes every where attend the cultivation of the country; and have formed a remarkable change of climate in those states, which have been long settled. 
In this cliange of climate, the first effect which is generally observed, is an alteration in the temperature. The cold of the winters de. crease; the rivers are not frozen so soon, so thick, or so long, as they formerly were ; and the effects of extreme cold, in every respect, appear to be diminished. A remarkable change of this kind, has been observed in all the settled parts of North America. The bays and rivers in New England, are not frozen so hard, or so long, as they were at the first settlement of the country.* At the first settlement of Philadelphia, the river Delaware was commonly covered with ice, about the middle of Norember, old style. $\dagger$ It is not now commonly covered with ice, until the first week in January. Similar observations have been madle with regard to the ice in Hudson's river.f The baron Lahontan gave this account of the river St. Lawrence, at Quebec, in 1690: "I put to sea the twentieth of November, new style, the like of which was never seen in that place before. The ice had covered the river on the thirteenth and fourteenth of November, but was carricd off by a sudden thaw." $\|$ The river is not frozen over now until the latter end of December, or the beginning of January. The ancient people at Quebec, in 1749, informed Mr. Kalm, that the winters in Canada were formerly much colder, than they were then.ई Similar observations have been made in almost every part of North

* New England's Prospect, by W. Wrood ; written in $16,33, p \cdot 40$

+ Kalm's Travels, Vol. i. p. 4 To.

+ Smith's History of Newyork.

i) Voyages to North America, p. I6j.

Kalm's Travelo, Vul. II, p. 382. 
America, where settlements and cultivation have taken place.

AL ThOU G H the general effect has been every where apparent, it is not an easy thing to ascertain the degree, to which the temperature has changed, in any particular place. When our ancestors first came into America, thermometers were not invented: And they have not left us any accurate meteorological remarks or observations, from which we can determine the exact degree of cold, which prevailed in their times. Upon looking over the most ancient writers of New England, the only account I have found, which will afford any distinct information upon this subject, is the following passage ; referring to years previous to 1633. "The extremity of this cold weather lasteth but for two months, or ten weels, beginning in December, and breaking up the tenth day of ficbruary (21st new stile) which hath become a passage very remarkable, that for ten or a dozen years, the weather hath held himself to his clay, unlocking his icy bays and rivers, which are never frozen again the same year, except there be some small frost until the middle of March." The winter is less severe now in several respects : The extremity of the cold weather does not come on so soon by several weeks; the bays at Boston, instcad of being annually cover. ed with ice, are but scldom frozen to this degree; and they do nat continue in this state a longer time than eight or ten days. In the year 1782, the harbour between Bosion and Charlestown was frozen to such a degree, that Y Wood's Prospect, D. A. 
horses and sleighs passed over the ice, for five or six days. This was the beginning of such an effect, as that which is mentioned in the ancient account. The ice became fixed and permanent on February second; and continued in this state until February 10th. During that time I found the lowest degree of Farenheit's thermometer to be -9 clegrees; the greatest degree was 28 degrees: and the mean heat was 13 degrees. It may be presumed therefore, that the freezing of the bays of which Wood speaks, could not have taken place, or continued, in a less degree of cold than this. This will give us 13 degrees of Farenheit's thermometer, as the mean heat which took place during eight or ten weeks of the winter, so far back as the year 1630. By the meteorological observations which I made in the University at Cambridge for seven years, from 1780 to 1788 , I found the mean heat in the month of December was 29 degrees 4 tenths; in January it was 22 degrees 5 tenths; and in February it was 23 degrees 9 tenths. These numbers express the present temperature of the winter at Boston. If this computation be admitted, the change of temperature in the winter, at Boston, from the year 1630 to the year 1788 , must have been from ten to twelve degrees.

A permanent alteration in the temperature of the climate or atmosphere, supposes an alteration equally great and permanent, in the heat of the earth. Whether the heat of the earth is thus affected by cultivation, and what will be its effects, $I$ endearoured to ascertain in the following manner. On the 2sd of May, 1789, I sunk 
a thermometer to the depth of ten inches below the surface of the earth. Upon repeated trials the quicksilver stood at fifty degrees: this mas in a level open field, used for pasture or grazing, and fully exposed to the sun. The same experiment was then made in the woods, where the surface of the earth was covered with trees, and never had been cultivated. To ascertain the gradual increase of heat at each place, the observations were often repeated. The result was as follows.

Time. Heat in the'Heat in thelDifference.

\begin{tabular}{|c|c|c|c|}
\hline & Pasture. & Woods. & \\
\hline \multirow{2}{*}{ May } & $50^{\circ}$ & $46^{\circ}$ & $6^{\circ}$ \\
\hline & 57 & 48 & 9 \\
\hline \multirow[t]{2}{*}{ June } & 64 & 51 & 13 \\
\hline & 62 & 51 & 11 \\
\hline \multirow[t]{2}{*}{ July } & 62 & 51 & 11 \\
\hline & $651-2$ & $\begin{array}{llll}5 & 1 & 1\end{array}$ & 10 \\
\hline \multirow[t]{2}{*}{ August } & 68 & 58 & 10 \\
\hline & $591-2$ & 55 & $41-2$ \\
\hline \multirow{3}{*}{$\begin{array}{l}\text { September } \\
\text { October }\end{array}$} & $591-2$ & 55 & $41-2$ \\
\hline & $591-2$ & 55 & 4.1-2 \\
\hline & 49 & 4.9 & 0 \\
\hline \multirow[t]{2}{*}{ November } & 4.3 & 4.3 & 0 \\
\hline & $431-2$ & $431-2$ & 0 \\
\hline
\end{tabular}

THE effect of cuitivation with regard to the heat of the earth, so far as it can be collected from these experiments, appears to be this: Fxposing the land to the full force of the solar rays in this latitude, will produce an heat at the rlepth of ten inches below the surface, ten or cleren degrees greater than that which prevails in the uncuitivated parts of the country; and 
this effect continues while the solar rays are sufficient to increase the heat of the earth. This additional heat in the earth, will be sufficient to produce the same alteration in the temperature of the air ; for whatever degree of heat prevails in the earth, nearly the same will be communicated to the lower parts of the at. mosphere. 'Thus the earth and the air, in the cultivated parts of the country, are heated in consequence of their cultivation, ten or eleven degrees more, than they wcre in their uncultivated state: It should seem from these observations that the effect, or the degree of heat produced by cultivation, is the same with the change of climate, that has taken place in the eastern part of Massachusetts.

AN отнER remarkable effect which makes part of the change of climate, and always attends the cultivation of the country, is an alteration in the moisture or wetness of the earth. As the surface of the earth bccomes more warm, it becomes more dry and hard, and the stagnant waters disappear. Alterations of this kind, have been common and great, in all the ancient settlements in the United States. Many of the small streams and brooks are dried up : Mills, which at the first settlement of the country; were plentifully supplied with water from small rivers, have ceased to be useful. Miry places, and large swamps, are become among the richest of our arable lands. In the new settlements the change is effected in two or three years : Fields of com and wheat are attended with the most rapid vegetation, and the greatest increase, in lands, where the waters five or six years ago, 
were stagiiant, and in such quantities as to be spread over the largest part of the ground. One of the first effects of culcivation is the dispersion of thesc. waters, and a change in the soil, from the appearance of a swamp, to that of a dry and fertile ficld.

THERE are two ways in which cultivation operates, to produce this effect. By the cut. ting down of the trees, the dispersion of a rast quantity of fluid, emitted by their evaporation, is prevented ; and by laring the lands open to the influence of the sun and winds, the evaporation of the stagnant waters is greatly promoted. The effect of the first, from experiments whicls will be related when the vegetable productions are considered, may be estimated at three thousand and eight hundred gallons of water thrown off from the trees on one acrc, in the space of twelve hours, in hot weather. 'To ascertain the effect which might arise from the latter, on June 27 th, 1789, a fair, calm and hot day, I placed a china saucer on the ground in the woods, where it rias covcred from the solar rays by the trees, the leaves of which at the height of tcn or twelve feet, were very thick. Another saucer in all respects similar to this, was placed on the ground in an open field adjoining, where it was fully exposed to the wind and sun. I poured into each of them equal quantities of water ; at the end of three hours the evaporation from the latter, was to that from the former, as six eight tenths to one. 'With regard then to the moisture or wetness of the country, it appears that settlement and cultivation will be sufficient to prevent the discharge 
of three thousand and eight hundred gallons of water, over one acre of land, in 12 hours, during the hot weather; and at the same time to effect the dispersion of 6 times and 8 tenths as much water from the surface of the earth, as would have been dispersed in its uncultivated state. If we may judge upon a matter which cannot be reduced to exact calculation, it should seem that the cause was here equal to the effect.

A change in the climate hath also been manifest in the apparent decrease of the snow, in all the ancient cultivated parts of the United States. Whether there has been any alteration in the annual quantity of rain in any part of America, we cannot determine, for want of meteorologic.. al observations; but a great decrease of snow has been observed in all the ancient settlements. At the first settlement of New England, the earth was generally covered with snow for more than three months in the year. It began to fall in large quantities by the first of December, and seldom went off until some time in March. This is yet the case in the inland and mountainous parts of the country. The snow covers them for three months, and is scarcely ever carried off by a thaw until the spring comes on. In those parts of the country which have been long setiled and cultivated, the snows have been declining for many years. They are neither so frequent, deep, or of so long continuance, as they were formerly : And they are yet declinıng very fast in their number, quantity, and duration. This event is derived from the change of temperature, which has taken place in the at. mosphere; and probably will keep pace exactly $\mathrm{K}$ 
with it. There has also been an apparent alteration in the direction of the winds. The prevalency and extent of the westerly winds, secm to be abating: Or rather the easterly winds are certainly increasing in their frequency and extent. These winds are now very frequent in the spring, in all that part of the country, which lies within sixty or serenty miles of the sea coast. Hall a century ago, the easterly winds seldom reached firither than thirty or forty miles from the sea shore. They have now advanced as far as the mountains, which are generally eighty or an hundred miles from the occan. As the comtry becomes setiled and cleared, they are found to advance more and more, into the internal parts of the country. It can hardly be doubted, but that this event is owing to the increasing cultivation of the country. As the woods are cut down, the earth and atmosphere become more heated than the ocean : The direction of the winus will of course be from the sea, towards the land. As the country becomes more setited and cleared, it is probuble these winds will continue to advance further torards the west.

THi same causes which producc a change in the heat of the earth, in its wetness, in the snow and winds, will produce as great a change in the weather and seasons. While the state of a country remains unaltered, the general course and appearance of nature will be the same, from one age to another. Surmer and winter, spring and fall, the productions of the earth, the state, of the air and weather, will be subject to but little annual altcration or change. But when 
the whole face and state of a country are chang. ing, the weather and seasons will also change with them. This is an event that has already taken place in the most ancient and cultivated parts of America: Whon oureancestors first came into New England, the scasons and weather were uniform and regular. The winter set in about the beginning of December, old style, and continued until the miclde of February. During that time the weather was generally fair, and cold, and without much change. 'Towards the end of February the winter generally broke up. When the spring came on, it came on at once; without repeated and sudden changes from heat to cold, and from cold to heat. The summer was extremely hot and sultry, for a month or six weeks; but it was of a short duration. The autumn commenced about the beginning of September ; and the harvest of all linds was gathered by the end of that month. A very different state of things now takes place, in all that part of New England, which has been long settled. The seasons are much changed, and the weather is become more variable and uncertain. The winter is intermixed with great and sudden thaws, and is become much shorter. The changes of weather and temperature, are great and common in the spring; and at that season there is generally an unfortunate fluctuation between heat and cold, greatly unfavorable to vegetrion, and the fruits of the earth. The summers are become more moderate in respect to the cxtreme heat of a few weeks ; but they are of a much longer duration, The autumn conmences, and ends, 
much later than formerly : the harvest is not finished until the first week of November ; and the severity of winter does not commonly take place, until the latter end of December. But the whole course of the weather is become more uncertain, variable and fluctuating than it was in the uncultivated state of the country.

It is in these particulars, the change that has taken place in the heat of the earth, in its wetness, in the snow, winds, weather and seasons, that the change of cliniate in North America has principally appeared. That this change of climate is much connecied with, and greatly accelerated by the cultivation of the country, cannot be doubted. But whether this cause is stificient to account for all the phenomena, which have attended the change of climate in the various parts of the earth, seems to be uncotain.** 


\section{CHAPTER V.}

Vegetable Productions.... Forest Trees, Esculent and Medicinal Vegetables. Remarlss on the Magnitude, Number, Age, Evaporation, Emission of Air, Heat, and Effect of the Trees.

WHEN the Europeans first took possession of North America, it was one continued forest, the greatest upon the earth. The country was every where covered with woods, not planted by the hand of man; but derived from, and ancient as the powers of nature. The great variety of plants and flowers, the immense numbers, climensions, and kinds of trees, which spread over the hills, valleys and mountains, presented to the eye, a most magnificent and boundless prospect. This is still the case with the uncultivated parts of the country.

Much the largest part of Vermont is yet in the state, in which nature placed it. Uncultivated by the hand of man, it presents to our view a vast tract of woods, abounding with trees, plants, and flowers, almost infinite in number, and of the most various species and kinds. It would be the employment of many years, to form a complete catalogue of them. I shall not attempt to cnumerate any, but those which are the most common and useful.

\section{FOREST TREES.}

THE Trees which are the most large and com: mon are the

White Pine. Pinus Strobus. 
Yellow Pine. Pinus Pinea.

Pitch Pine. Pinus Treda.

Larch.s Pinus Larix.

Hemlock. Pinus Abies.

$\left.\begin{array}{l}\text { White Spruce. } \\ \text { Black Spruce. }\end{array}\right\}$ Pinus Canadensis.

Fir. Pimus Balsamea.

White Maple. Acer Negundo.

Red Maple. Acer Rubrum.

Black Maple. Acer Saccharinum.

White Beech.

Red Beech. $\}$ Fagus Syluatica.

White Ash. Fraxinus Excelsior.

Black Ash. Fraximus Americana.

White Birch. Bictula Alba.

Black Birch. Betula Nigra.

Red or Yellow Birch. Betute Lenta.

Alder. Betula Alnus.

White EIm.

Red Elm. $\}$

Ulmus Americaici.

Black Oak: Qucreus Nigra.

White Oak. Quercus Alba.

Pied Oak. Quercus Rubra.

Chesnut Oak. Quercus Prinus.

White Hiccory, or Walnut, Juglans Aiva.

Shagbark. Juglans Alba, cortice squamoso.

Butternut. Jugrlans Alba, cortice cathartico.

Chesnut. Fagus Castaner.

Buttonirood. Plantamus Occidentalis.

Basswood, or lime tree. Tilia Anicricana.

Iornbeam. Carpinus Beiulus.

Wild Cherry, several species.

Sassafras. Laurus Sassafras.

White Cedar. Thuja Uccidentalis.

Red Cedar. Juniperns Virginiana 
White Poplar, or Aspen. Populus Tremula. Black Poplar, or Balsam. Populus Nigra. Red Willow. Sulix.

White Willow. Salix Alba.

Hackmatack.

\section{FSCULENT.}

THE following are small Trees, Shrubs or Vines, valuable on account of their salubrious and pleasant Fruit.

$\left.\begin{array}{l}\text { Red Plumb. } \\ \text { Yellow Plumb. } \\ \text { Thorn Plumb. }\end{array}\right\}$ Prunus Sylvestris.

Thorn Plumb.

Black Cherry.

Red Cherry.

Choke Chorry.

Cerasus Syluestris.

Juniper. Juniperus Sabina.

Hazlenut. Corylus. Avellanc.

Black Currant. Ribes Nigrum.

Wild Gooseberry. Ribes Glosularia.

Whortleberry.

Bilberry.

Bluebeiry

Chokeberry,

Partridgcberry.

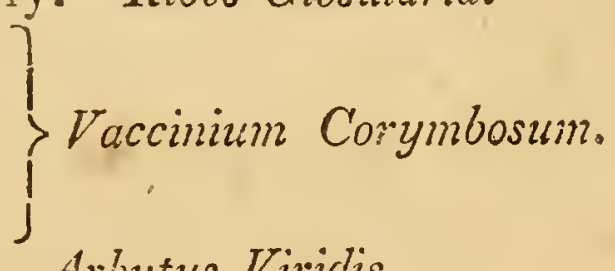

Pigeonberry. Cissus.

Barberry. Berberis Vulgaris.

Mulberry. Morus Nigra.

Black Grape. Vitis Labrusca.

Fox Grape. Vitis Vulpina.

Black Raspberry. Rubus Idaus.

Red Raspberry. Rubus Canadensis.

Upright Blackberry. Rubus Fruticosus.

Running Blackberry. Rubus Moluccanus.

Brambleberry. Riubus Occidcntalis. 
$\left.\begin{array}{l}\text { Cranberry. } \\ \text { Bush Cranberry. }\end{array}\right\}$ Vaccinium oxycoccos.

Strawberry. Fragaria Vesca.

Dewberry. Rubus Cissius.

Cloudberry. Rubus Chamemorus.

THESE fruits are in great abundance in the uncultivated parts of the country; but they secm to arrive to their highest perfection of numbers, magnitude and richness, in the new fields and plantations. "There are other vegetables which are also esculent, and valuable, chiefly on account of their roots or seeds. Among these are the

Artichoke. Helianthus Tuberosus.

Ground nut. Glicine Apios.

Long Potatoe.
Red Potatoe. Convoluulas Batatas.

Wild Leek.

Wild Onion.

Wild Oat. Zizania Aquatica.

Wild Pea.

Wild Hop. Humuhus Lupulus.

Indian Cucumber. Medeola.

\section{MEDICINAL.}

Many of the vegetables which are indigenous to this part of America, are applied to Medicinal jurposes. Of this nuture are the

Bitter Sweet. Solanum.

Angelica. Angelice Sylvestris.

Black Elder. Sumburus Nigra.

Red Elder. Fibuinum Opuilus.

Sarsaparilla. Aralia.

Pettymorrel. Aralia Nigra. 


\section{HISTORY OF VERMONT. 85}

Solomon's Seal. Convallaria.

Maiden Hair. Adianthus Pedatus.

Arsmart. Polygonum Sagittatum.

Wild Rose. Kosa Sylvestris.

Golden Thread. Nigella.

Mallow. Malva Rotundifolia.

Marshmallow. Althea.

Lobelia, several species.

Senna. Cassia Ligustrina.

Clivers. Gallium Spurium.

Blue Flag. Iris.

Siveet Flag. Acorius.

Skunk Cabbage. Arim Americanims

Garget. Phytolacca Decandra.

Blood Root. Sanguinaria.

Pond Lily. Nymphera.

Elecampane. Inuia.

Black Snake Root. Actea Racemosa.

Seneca Snake Root. Polygala Senega.

Pleurisy Root. Asclepias Decumbens:

Liquorish Koot.

Dragon Root. Arum.

Ginseng. Panax Trifolium.

Ginseng was formerly esteemed a plant in digenous only to China and Tartary. In 1720, it was discovered by the Jesuit Lafitan, in the forests of Canada ; and in 1750 , it was found in the western parts of New England. It grows in great plenty and periection, in Vermont; The root has many virtues; but we do not find then to be so extraordinary, as the Chinese have represented. It was a valuable article in the commerce of Canada in the year 1752, and large quantities were purchased in this state but VOL.I. 
a few ycars agro; an injudicious method of collecting, curing and packing it, has greatly injured its reputation; this, with the large quantities in which it was exported, have nearly destroyed the salc.

I'o this account of mecicinal plants, it may sot be improper to subjoin those, which in their natural stute, are found to operate as foisons; the most of which, by proper preparations, become valuable medicines. Of these we have the

Thorn Apple. Datura Siramonium.

Henbune. Hyoseyumlis Niger.

Nightshade. Solanmm sivinm.

Ivy. Iedera Helix.

Creeping Ivy. Rhus Particans.

Swamp Sumach. Rhus Toxicodendium.

Baneberry. Actaa Spicaí.

White Hellebore. Veratrum Album.

$I_{N}$, adclition to these, there is a great variety of plants and fowers, the names and rirtues of which, are unknown. Some of our vegetables deserve a particular description, on account of their uncommon properties: Thus, the Bay-bery (myrica cerifera) is distinguished by a fine perfume, and a delicate green wax. The Prickly Ash is valuable for its ancommon aromatic properties. The Witch Hazel (hamamelis) is endowed with the singular property of putting forth its blossoms, after the fiost has destroyed its leaves. The Indian Hemp (asclepins) may be wrought into a fine, and strong thread. The Silk Grass another species of the asclefias, contains a fine soft down, which may be carded and spun into an excollent wickyarn. The ber- 
ries of the common Sumach (rhus) are used to great advantage in medicinal applications, and in several kinds of dyes. It would be a very useful, but a laborious employment, for the botanists to give to the world an enumeration, and scientific ciescription of our indigenous vegetables. The Flora Americana, would be the most valuable addition, that could be made to the works of the celebrated Limeus: But it cannot be completed without the united assistance of wealth, genius, time and labour.

To this imperfect catalogue of our vegetables, I shall add some remarks on the magnitude, number, age, evaporation, emission of air, heat, and effect of the trees.

M $\Lambda$ GNITUDE. The magnitude to which a tree will arrive, depends upon the nature of the tree, and of the soil. The following are the dimensions of such trees as are esteemed large ones of their kind, in this part of America. They do not denote the greatest, which nature has produced of their particular species, $*$ but the greatest of those which are to be found in most of our towns.

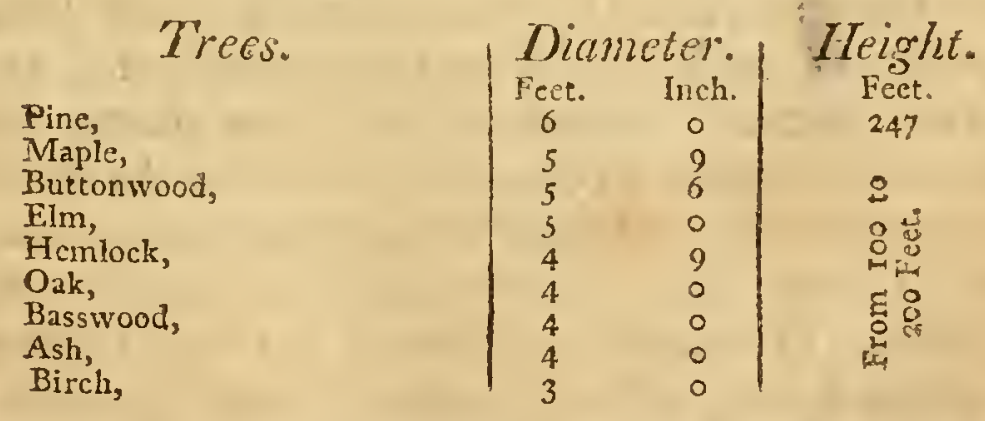

* A white Pine was cut at Dunstable in Newhampshi"e, in I736́, tae iameter of which was seven feet, eight inches.

Douglass' Summary, Vol. II. p. $55^{\circ}$ 
NuMBER. The number or thickness of the trees, seems to depend chiefiy on the richness of the soil. In some parts of the country they are so thick, that it is with difficulty we cin ride among them. In other places, they have resolv. ed themselves into trees of large dimensions, which are generally at the distance of eight or ten fect from each other. On one acre, the number of the trees, is commonly from one hundred and fifty to six hundred and fifty ; varying in their number, according to the richness of the soil, and the dimensions the trees have attained. Estimating a cord to be four feet in height, and width, and eight feet in length, the quantity of wood which is generally found on one acre, is from fifty to two hundred corcls; where the large pines abound, the cuantity of wood is much larger than what is here stated; but these trees are never measured as cord wood, but always applied to other purposes.

AGE. There is a circumstance attending the growth of trees, which serves to denote their age, with great accuracy. The body of a tree does not increase by an universal expansion of all its internal parts, but by additional coats of new wood: And these are formed cvery ycar, by the sap which runs between the bark, and the old wood. When a tree is cut down, this process of nature becomes apparent in the num. ber of parallel circles, or concentric rings, which spread from the $c \in$ ntre to the circumference of the tree. In many observations made by oth-. ers, and by myself, upon trees whose ages were known, the number of these circles was found to agree cractly with the age of the tree. By 
this methor of computation, I have found the pine to be the most aged tree of 012 forest, several of which were between three hundied and fifty and four hundred years of agge. The largest trees of other species, arc: generally between two and three hundred years. I am since informcd by James Whelpley, Esq. of Hubbardton that this is not correct; that he has made many observations of this kind, and has always found the Oak to be the most aged tree of the forest. By their rings or circles some of these trees appeared to him to be more than cne thousand years of age; and that some of the pines were of more than 600 years growth. In the more advanced periods of vegetable life, this method of computation often fails: The decays of nature generally begin in the central, which are the most aged parts. From them, the mortification gradually extends to others; and thus, the internal parts of the tree, die in the same order in which they were produced; the progress of death, regularly and steadily following the same order and course, which had been observed in the progress of life. In this state of a tree, no computation can be made of its age: But it seems most probable, that the time of its natural incrcase and decrease, are nearly the same; and that the natural period of vegetable life, is double to that, which the tree has attained, when it first begins to decay at the heart.

Evaporation. Besides the growth, there are other processes carried on by nature in vegetables, of which we have no suspicion, until their effects become apparent. This is the case 
with the craporation which takes place from the woods, during the summer montins. Erery tree, plant and regetable, is then pouring into the atmosphere, an amazing quantity of Huid. On the 12th of june, 1789, I put the end of one of the limbs of a sninll maple tree, into a bottle containing about one pint. That part of the limb which was within the bottle, contained two lcaves, and one or two buds. The mouth of the bottle was stopped with beeswax, that no vapour might cscape. In five or six minutes, the inside of the bottle was clouded, with a very fine vapour ; and in about half an hour, smail drops began to collcet on the sides, and rum dorm to the bottom. At the end of six hours, I weished the vater which had been collected in the bottle during that time, and found it amounted to sixtcen grains, troy weight. The tree on which this experiment was made, was eight inches and an hal in cliameter, and thirty feet in height. To makc an estimate of the quantity of water, thrown off from this tree into the atmosphere, in a giver portion of time, I endearoured to ascertain the number of leares which it contained. With this view (after I had made some other experinents) I had the tree cut down; and was at the pains to count the leares, which it contained : the whole number amounted to twenty one thousand one hundred and ninety two: Admitting the evaporation to be the same from the other leaves of the tree, as it was from those on which the experiment was made, the quantity of water thrown off from this tree in the space of trrelve hours, would be three hundred and thirty nine thou. 
sand and seventy two grains. Upon examining. the number and dimensions of the trees, which covered the ground where I made the experiment, I think it would be a moderate computation, to estimate them as equal both in magnitude and extent, on every square rod, to four such trees as that which I had examined. This will give six hundred and forty such trees, for the quantity of rood contained on one acre. This estimation is less than the quantity of wood, which is generally found upon one acie of land in this part of America. "The weight of one pint of water, is one pound avoirclupoise, or seven thousand grains, troy weight; and eight such pints make one gallon. Making the calculation upon these principles, it will be found that from one acre of land thus covered with trees, three thousand eight hundred and seventy five gallons of water are thrown off and dispersed in the atmosphere, in the space of twelve hours.

TH Is computation, will not appear extravagant to those, who have seen the great quantity of juice, which naturally flows out of some of our trees, when they are tapped in the spring. A man much employed in making maple sugar, found that for twenty one days together, one of the maple trees which he tended, discharged seven gallons and an half each day. A large birch which was tapped in the spring, ran at the rate of five gallons an hour, when first tapped; eight or nine days after, it was found to run at the rate of about two gallons and an half per hour; and at the end of fifteen days, the discharge continued in nearly the same quantity. 
The sap continucd to ruin four or five weeks, and from the remarks which were made, it was the opinion of the observer, that it must have yielded as much as sixty barrels.

The consequence of this waste of the juices was the death of the tree, the ensuing summer. I have this account from the Hon. Paul Brigham, Eso. These accounts serve to show, what a quantity of fluid, is naturally contained in some of our trees; and from a source so plentiful, a copious cvaporation might naturally be expected.

Enission of Air. Another curious operation, which nature cairies on in vegetables, of the highest use, but wholly invisible to us, is the emission of a large quantity of air. The tress, vegetables and flowers, while they are discharging a large quantity of water into the at. mosphere, are, at the same time emitting or throwing off a much larger quantity of air. On the 15 th of June, 1789 , I put the same part of the maple tree into a bottle, as I had done in the experiment of Jume 12th. The botile, with the limb of the maple thus enclosed, was then filled up with water ; and immersed in a large drinking glass, which had been filled before: In this situation the bottle was inverted, and fixed so as to have its mouth about three inches under the surface of the water, in the drinking glass. In fiftecn minutes, air bubbles began to appear around the leaves of the maple; and soon after to ascend to the upper part of the bottle, and collect into large bubbles; which; as they increased, resolved themselves into one: At the end of six hours, I found the quantity of water which had been forced out of the bottle; 
by the air which was collected in it, amounted to sixty one grains. The quantity of air therefore, estimated by its bulk, which was emitted from the limb of the tree, was to the quantity of water thrown off from the same limb, as six ty one to sixteen. Making the calculation in the same manner as before, this will give fouro teen thousand seven hundred and seventy four gallons, as the quantity of air, thrown off in twelve hours, from one acre of land, thus cov. ered with trees. The purity and salubrity of this air is as remarkable as the quantity of it. It has been found that an animal will live five Times as long in this kind of air, as in common air of the best quality. The purity of the atmosphere, is constantly impaired by the respira. tion of animals, by combustion, the putrefaction. of bodies, and by various other causes. In such ways, the air over large and populous cities, is so greatly and constantly corrupted, that it would soon become unwholesome and noxious to the inhabitants, if it was not removed, or purified. Nature has made abundant provision/for this purpose, in the immense quantities of air, which new countries supply. The trees and vegeta. bles perpetually produce it, in large quantities, and in the purest state; and the winds carry it from one country to another, where it is n.ost wanted.

Heat. The principle by which these operations are carried on, and which seems to have the greatest effect in vegetation, is heat. Different vegetables require different degrees of heat, or different climates, to give them their greatest degree of increase, and perfection.

roL. I. 
All of them cease to grow, when their roots are in a state of congelation. As soon as the warmth of the spring comes on, the sap begins to ascend in their trunks, and branches : A fermentation takes place in all their juices, and the vegetation becomes more or less rapid, as the heat of the season advances. In Vermont, about the tenth of May, the Maple, which is one of the most numerous and forward trees of the forest, begins to put forth its leaves. In one or two days after, the whole body of the woods, appear of a beatitiful light green ; and are constantly growing of a darker colour, for ten or fifteen days, when the darkest shades become fixed. During this period, the juices of the trees appear to be in a state of high fermentation, their internal heat increases, and the effects of their vegetation appear in an infinite variety of buds, leaves and howers. To ascertain the degrees of heat, in different trees, at different times of the year, and to mark their effects on the leaves, and fruits, the following experiments iwere made. With an auger, of one inch di. ameter, I bored an hole twelve inches long, into the body of the tree : In this hole, I enclosed a thermometer of Farenheit's scale, stopping the orifice with a cork, until the quicksilver had acquireal the degree of heat, which prevailed in the internal part of the tree. 'The result of these experiments, is set down in the following table. 


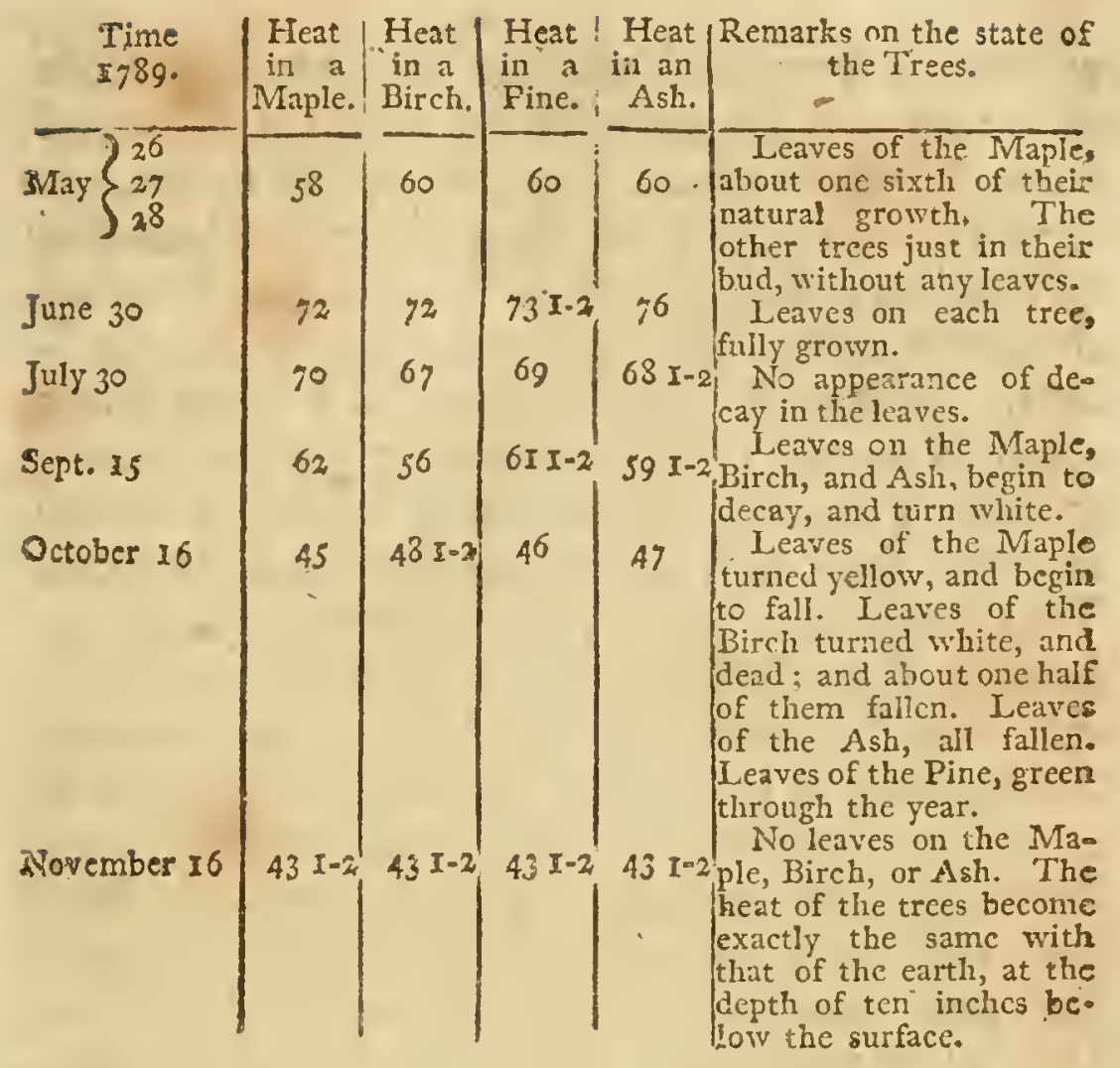

From these observations it should secm, that the temperature or heat of trees, is not the same as that of the earth, or atmosphere; but is a heat, peculiar to this class of bodies. It is probably the same, in all trees of the same kind, in similar circumstances and situations. The degree and variations of it, seem to depend on the fermentation of the juices, and the state of vegetation. It is not improbable the heat of the same kind of trees, may be different, in different latitudes: Whether this is the case or not, can be known only, by observations, made in different countries. This heat which prevails in trees, seems to be the great principle or agent, by which the two fluids of water and air, are 
separated from one another, and emitted from the trees. The quantity of water evaporated from the trees on one acre, in twelve hours, we. have found to be three thousand eight hundred and seventy five gallons: That of air, fourteen thousand seven hundred and seventy four gal. lons. Before the evaporation, both these fluids seem to have existed together in a fixed state; making a common mass, every where dispersed through the body, limbs, and leares of the trees. When the heat of the internal parts of the trees, became from fifty eight to sixty degrees of Farenheit's thermometer, the budis were formed, the leaves put forth, and the one fluid, scems to have been separated, or formed into the two fluids, of water and air. It seems probable from this, that both these fluids had the same origin, that heat was the principle, or cause by which they were separated; and that about fifty eight, is the degree of heat, which is necessary to begin the separation of the air from the water.

EFFET. The effect of this perpetual vegezation, growth, and decay of vegetables, is an cxtreme richness and fertility of soil. Neither destroyed or removed by the hand of man, the vegetable productions of the uncultivated parts of America, return to the earth by decay and death, and corrupt on the surface from which they grew. It is not only from the earth, but from the air and water, that trees and plants derive their nourishment, and increase: And where no waste has been occasioned by man or other animals, it is not impossible that the vegetables. may return more to the earth, than they have taken from it; and instead of serving to im. 
poverish, operate to render it more rich and fer. tile. Thus does the soil, in the uncultivated parts of the country, from age to age derive increase, richness and fertility, from the life, growth, death and corruption of her vegetables. This effect has been so great in America, that when our lands are first cleared of the wood, we always find a black, soft, rich soil, of five or six inches depth; wholly formed of decayed or rotten leaves, plants, and trees. The extreme richness of this factitious soil, produces a luxuriancy of vegetation, and an abundance of increase in the first crops, which exceeds any thing that can afterwards be procured, by all the improvements of agriculture.

Powers of Vegetable Life. The power with which nature acts in the productions of vegetable life, in this part of America, may be deduced from such circumstances as have been mentioned: From the immense extent of cur forests ; from the magnitude, number, and variety of our trees, and plants; from their rapid increase, and duration ; and from the total want of sandy cleserts, and barren places. These and other circumstances, denote an energy, a power in the vegetable life, which nature has never ex. cceded in the same climate, in any other part of the globe. 


\section{CHAPTER VI.}

Native Animals. An account of the Quadrupeds; with Ousercutions on their Enumeration, Origin, Migration, Species, Magnitudes Disposition, and multiplying Power. The Birds, Fishes, Reptiles and Insects.

THE uncultivated state of America was favcurable to the productions of animal life. A soil naturally rich and fertile, and powers of ve. getation extremcly vigorous, produced those immense forests, which spread over the continent. In these, a great variety and number of animals had their residence. Fed by the hand and productions of nature, unmolested but by a few and unarmed men, the productions of animal life every where appeared, in the rarious forms of quadrupeds, bircls, fishes, and insects ; and their increase and multiplication, became quick and rapid.

\section{QUADRUPEDS.}

OF that species of animals which are known by the name of quadrupeds, America contains nearly one half : Of these about thirty six, are found in Vermont. Our forests afford shelter and nourishment for the moose, bear, wolf, deer, fox, wild cat, racoon, porcupine, woodchuck, skunk, martin, hare, rabbit, weasel, ermine, squirrel, mole, and mouse. In our rivers, ponds, and lakes, the bearer, muskrat, minks and otter, are to be found in large numbers. 
'THE largest animal which is known in Ver-' mont is the Moose. It seems to be of the same species as the Elk; and in its general form, it resembles the horse. His head is large, the neck short; with a thick, short, and upright mane, the cyes are small, the ears are a foot long, very broad, and thick; under the throat, there is a fleshy protuberance; the nostrils are large; the upper lip square, and hangs over the lower. His horns are palmated, and when fully grown are about four or five feet from the herd to the extremity : There are several shoots or branches to each horn, which generally extend about six feet in width from each other. The horns weigh from thirty to fifty pounds, and are shed every year. The hoofs of the Moose are cloven; his gait, is a long shambling trot; his course, very swift, and straight. Wrhen he runs, the ratling of his hoofs, is heard at a considerable distance; in miry places, his hoofs are spread several inches from one another; and it is with the greatest ease, that he leaps over the highest of our fences. The Moose is generally of a grey, light brown, or mouse colour. The food of this animal is grass, shrubs, the boughs and bark of trees, especially the beech, which they seem to prefer above all others, and a species of maple which is called moose wood. In sum: mer, they keep pretty much in families. In the winter, they herd together to the number of twenty or thirty, in a company: They prefer the coldest places; and when the snow is deep, they form a kind of yard, consisting of several acres, in which they constantly trample down the snow, that they may more easily range 
round their yard; and when they cannot come at the grass, they live on the twigs and bark of the trees. Their defence is chiefly with their fore feet, with which they strike with great force. The female is less than the male, and generally without horns. The rutting season is in autumn: 'The female generally brings forth two at a birth, in the month of April, which follow the dam a whole year. One of these animals in Vermont, was found by measure, to be seven feet high. The largest, are estimated by the hunters, to weigh thirteen or fourteen hundred pounds.

THE BEAR is frequently to be met with in this part of America, and is always of a black colour. It is not an animal of the most fierce, and carnivorous disposition. There have been instances, in which children have been devoured by the bear; but it is only when it is much ir. ritated, or suffering with hunger, that it makes any attack upon the human race. At other times, it will destroy swine and young cattle. but has not been known to make any attack up. on men; but always aims to avoid their pursuit. The food of this animal is corn, sweet apples, acorns, and nuts. In the end of autumn, the bear is generally very fat, and chooses for the place of his retreat the hollow of a rotten tree, or some natural den, or cavern in the earth. In such a situation he uses no exercise, appears to be asleep, loses but little by respiration, and is always found without any provision ; and it is not until the warmth of the spring returns, that he leaves his retreat, or goes abroad in quest of food. This animal is valuable for its flesh, 
grease, and skin. The female generally bears two cubs a year. The bear arrives to a great magnitude in this part of the continent. The largest, of which the hunters give us any certain information, weighed four hundred and fifty six pounds.

$\mathrm{O}_{N} \dot{\mathrm{E}}$ of the most common and noxicus of all our animals, is the Worf. In the form of his body, the wolf much resembles the dog. He has a long head, a pointed nose, sharp and erect ears, a short and thick neck, with sharp and strong teeth. His eyes generally appear sparkling; and there is a mildness; and a fierceness in his looks. 'The colour of the wolf in Vermont, is a dirty grey ; with some tinges of yellow about his ears, and legs. This animal is extremely fierce, sanguinary, and carnivorous. When a number of them associate, it is not for peace, but for war and destruction. The animal at which they most of all aim, is the sheep. When they can find a flock of these, they seem to delight in slaughter; tearing their flesh, and sucking their blood, after they are fully satisfied with the fat of their tender parts. They attack the deer, foxes, rabbits, and are enemies to all other animals; and their attacks are generally attended with the most horrid howlings. They generally flee before the face of the hunter; but when they have once tasted of human flesh, they become more fierce, and daring, and seem to be inflamed with greater fury. In such a state, there have been instances in Vermont, in which the wolves have ventured to make their attacks upon men; but they generally retire upon their approach. They are not often to be seen in the VOL. I. is 
day, but in the night venture into our yaros, and barns. These animals are yet in great numbers, in this state; they destroy many of our sheep, in the night; and find a safe retreat in our woods, and mountains; but are gradual. ly decreasing, as our settlements increase, and extend. The wolf is a very prolific animal. The female is in season in the winter, but the male and female never pair. The time of ges. tation, is about three months and an half; and the young whelps are found from the begining of May, until the month of July. The hunters have sometimes found in their dens, a male, a female, and a litter of nine young whelps. One of the largest wolves in Vermont, weighed nine. ty two pounds. There is nothing valuable in these animals but their skins, which afford a warm and durable fur.

THE DEER is one of our most common and valuable animals. In the spring he sheds his hair, and appears of a light red; this colour gradually groivs darker until autumn, when it becomes a pale, or cinerous brown; and re. mains thus through the winter. His horns are slender, round, projecting forwards, and bent into a curve; with branches or shoots on the interior side. These branches do not commence, until the deer is three years old; from which period, a new one rises every ycar; and by this circumstance, the hunters compute their age. These lorns are cast every spring; the new ones, in the course of a year, will grow two feet in length, and reigh from two to four pounds. The amorous season with these ani. mals, is in the month of September. From 
September to March, the bucks and does herd together; early in the spring they separate, and the does secrete themselves in order to bring forth their young; which generally happens in the month of April. The female generally bears two, and sometimes three, at a birth. The fawns are red, most beautifully spotted with winite. They are easily tamed, and become as gentle and domestic as a calf. The deer is an animal of great mildness, and activity. They are alvays in motion; and leap over our highest fences, with the greatest ease. The largest of which I have a particular account, weighed three huidred and eight pounds. The deer are numerous in Vermont; and on account of their flesh and skin, are of much value. The rein. deer is not to be found in this part of the continent. But there seems to be another species of the American deer, distinguished chiefly by its horns, and often by its colcur. The horns of this deer are never extensive, broad, and branched, like those of the common deer : But they are round, thick, but littlc curved, and not more than ten or twelve inches in length. This spe. cies is generally larger than the other: Several of them have large white spots, and some have been killed which were wholly white

THE FOX abounds much in this part of $A$. merica. The form, disposition, and habits of this animal, are every where known. We have four kinds of foxes in Vermont.

The Red Fox bears upon a yellowish, or rather a straw colour. This is esteemed the common forr, and is the most fiequently to be found. At its full growth in the fall; this animal weighs twenty pounds. 
Tн $\mathrm{E}$ Grey Fox resembles the other in form, and magnitude, and appears to differ from it only in colour, which is of a beautiful silver grey.

The Cross Fox resembles the other in form, and magnitude; but has a black streak, passing transversely from shoulder to shoulder; with another along the back, to the tail. The other parts of this animal are of a red, or more gener. ally of a grey colour.

The Black Fox is the largest, and most valuable of all. The fur of this fox is the most fine, soft, and rich, of any. One of the largest of the black fores, was found to wcigh twenty three pounds.

The Fox is a very voracious animal; de; vouring all kinds of poultry, birds, and animals, which they can overcome. Flesh, fruit, honey, and every part of the farmer's dairy are devour: ed by him with great avidity. This animal is very prolific. The female is in season every year, in the vinter; and gencrally produces in the month of April ; the litter is generally from three to six.

Tine Catamount, secms to be the same animal, which the ancients called Lynx, and which is known in Sibcria, by the name of Ounce. In the form of its body it much re. sembles the common cat, but is of a much lar: ger size. It is generally of a yellow grey colour, bordering upon a red or sandy; and is larger than our largest dogs. This seems to be the most fierce and ravenous of any animal, which we have in Vermont. Some years ago, one of these animals was killed at Bennington. It took a large galf out of a pen, where the fence 


\section{HISTORF OF VERMONT. 103}

was four feet high, and carried it of upon its back. With this load, it ascended a ledge of rocks, where one of the leaps, was fifteen feet in height. Two hunters found the cat upon an high tree. Discharging his musket, one of them wounded it in the leg. It descended with the gracatest agility, and fury ; did not attack the men, but seized their dog by one of his ribs, broke it of in the middle, and instantly: leaped up the tree again with astonishing swift. ness, and dexterity. The other hunter shot him through the head, but his fury did not cease, but with the last remains of life. These animals have been often seen in Vermont; but they never were very numerous, or easily to be taken. Of their fecundity, I have no particular information. On account of their fierceness, activity, and carnivorous disposition, the hunters esteem them the most dangerous of any of our animals. The weight of one of them, was estimated by the hunter, at one hundred pounds. The length of his body was about six feet, that of the tail, three; the circumference of the body was two feet and an half, and the legs were about thirteen inches long.

WHAT is called the WILD CAT, is an animal, in most respects similar to our common cats; but different in its disposition, and dimensions. It is much larger, stronger, and fiercer, than any of our domestic cats; and seems to be of the same disposition, and colour, as the wolf. One of the largest of them was found by the hunter, to weigh fifty seven pounds:

The Black C $A$ T does not appear to be dis: tinguished from the former, in any other respect. 
than its colour. It is allogether black, and sel. dom grovis to so large a size, as the former. It seems to be of a distinct spccies; is as fierce and ravenous as the other kind. These animals are frequently found in the woods; very wild, extremely ficrce in combat, of great activity and strength; but never can be tamed, or made to associate with our common cats. They are valuable only on account of their furs. The black cat was called by the Indians, the $I$ Vooltaneeg: The largest of which I have any account, weighed trenty three pounds.

ANOTHER animal which does not greatly dif. fer in appearance from a wild cat, has been calied the blvorine. The body of this animal is about two feet and an half in length. It has a short tail, and is of the same colour as the wolf. This animal is of a very fierce, and carnivorous disposition. Concealing himself among the rocks and bushes, or taking a station upon the limb of a tree, he watches for the approach of prey. If the deer, or the moose comes within his reach, he darts upon their backs, fastens up. on their neck, and with great dexterity opens their jugular vein with his tecth. This animal is scarce, and not to be found but in the nor. thern, and most uncultivated parts of the state. I have no account of its fecundity, magnitude, or other particulars.

The Racoon, in its shape or general form, resembles the fox, but has a larger body, with thicker and shorter legs. The fect have five long and slender toes, armed with sharp claws. "The males have gencrally a large whitish stripe, and the females a smaller one, which runs across 
the forehead. The tail is long, and round, with annular stripes' in it. This animal dwells in the retired part of the woods, runs up the trees with great agility, and ventures to the extremes of the boughs. Its fur is thick, long; and soft; and of a dark grey colour. The weight of one of the largest in Vermont, was thirty two pounds. It is often found in hollow trees, and its flesh is excellent food.

The Porcupine, or Hedgehog, is not un. common in Vermont. What is singular and most distinguishing in this animal, are the quills with which he is armed. These quills are about four inches in length; and of the size of the quills of a pigeon. When the porcupine is attacked by an enemy, he places his head be. tween his fore feet, and erects these quills all around, in the form of an hemisphere. He has no porver to eject them from his body, or dart them against his enemy, as has been frequently said. But they are so loosely inserted in his flesh, and of such a particular construction, that they are easily extracted, and like a barbed dart stick fast, and work themsclves into the flesh of any animal that touches their extremities; nor can they be easily withdrawn, without tearing the flesh, but by incision. On this account they prove extremely dangerous to the dog, or to any other animal that makes an attack upon the porcupine. The colour of this animal, is grey : His motion is extremely slow. The fe. male produces her young every year; the time of gestation is about forty clays, and she gener. aliy brings forth three or four at a birth. One of the largest of these animals, weighed sizteer 
pounds : The fiesh is said to be agrecable, and wholesome ment.

Asother animal, which we frequently find in the ficlds, is the WOODCHUCR. This animal is about sixteen inches in lengtl ; its body is large, and round; its legs are short; and its fore feet are broad, and fitted for the purposse of burroving into the earth. 'The colour of the woodchuck is brown, his fat is extreme, the flesh is wholesome and palatable food, his fur is not very valuable. This animal resicles in a hole which he digs in the ground, and feeds up. on grass, corn, beans, and other regetables. 'The female generally produces four or five at a birth. One of the fattest which I have seen, weighed eleven pounds: I believe this was one of the largest size.

THE SKUNK is one of the most extraordinary animals, of which we have any account. It secms to be of the same species with the polecat, but is of a less size, and difiers from it in several respects. Its hair is long, and shining, of a clouded or dirty white, intermixed with spots of black. Its tail is long, and bushy, like that of the fox. It lives chichy in the woods, and hedges, but often burrows under barns and out houses. When undisturbed, this animal is without any ill scent, or disagreeable effuvia. Their natural cracuations are not more nauseous, than those of other animals. Whole nests of them will lie under the floor of a barn, and so long as they are undisturbed, no disagreeable odour will be perceived during the whole winter. Their flesh, when it is properly dressed, is sweet and nourishing. When pursued or attacked, 
the skunk discovers its extraordinary powers, by a singular and most effectual method of de. fence. It emits a fluid of the most nauseous and intolerable scent, that has ever been known. So odious, subtle, and penetrating, is this ill scented matter, that there is no animal which can long endure it, or will venture to approach the skunk, when he is throwing it out. It infects the air to the distance of half a mile all around : And no method has been found, to extract the scent out of any object, on which the odious fluid has been thrown. 'Time and air, after a long period, affords the only complete remedy. By accurate dissection lately made by Dr. Mitchell, it has been found that this ill scented fluid, is entirely distinct from the urine. It is contained in two bags, situated in the posterior parts of the body ; and surrounded by the circular muscles in such a manner, that by their constriction, the fluid is forced out with great velocity and force. The urinary organs are totally distinct from these bags.* The female produces a litter every year; and they generally amount to five or six in number. One of these animals weighed seven pounds and an half, but whether it was one of the largest size, I cannot determine.

The Martin is an animal, peculiar to cold climates. It is found in large numbers in Vermont, but chiefly in the most retired, and thick. est parts of the woods. Its colour is a dark brown, with tinges of yellow; sometimes the colour approaches to a black: The fur is fine,

* American Museum, Vol. V. p. $48 \%$

YOL. I.

O 
soft, and much esteemed. This animal is fiom eighteen to twenty inches in length. A large one was found to weigh five pounds and one quarter of a pound. The female produces from three to six young ones, at a litter. The martin and sable denote the same animal in Vermont.

TIE HARE is about eighteen inches in length: It is always of in white colour, and has a fine, and beautiful fur: Its fesh is a very nourishing, and delicious food. This animal is very prolific. The time of gestation is about thirty days: "The female bears three or four at a birth, and has several litters in the course of a year. A large hare weighs eight pounds. The hunters find large numbers of these animals, in this part of the country.

'THE RABEIT is something less than the hare, but in greater numbers. His colour, both in summer and winter, is a light grey, or dirty white. The length of the rabbit, is about sixteen or seventeen inches; one of the largest of them, weighed seren pounds. The rabbit is more prolific than the hare. The female bcars sooner, and has from four to eight, at a litter. These animals are readily found, in every part of the stinte.

The Weased has the form and appearance, of a squirrel; but is more slim, and active. His eyes have an uncommon sprightliness; his look is keen, and piercing; and his motions are so quick, and various, that the cye can scarcely follow them. This animal is of a red or brown colour, and has a white belly. Its fur is very fine, and soft. His fool is corn, nuts, eggs, 
and all kinds of small animals. The reascl is often found in hollow trees, and he frequently enters into houses, barns, and other buildings, in search of grain, chickens, mice, and young animals. In Vermont, the weasel is about twelve inches in length; very narrow and slim, and weighs about twelve ounces. The female bears three, four, or five, at a birth ; but they do not appear to be very numerous.

The Ermine is the most beautiful quadruped, which is seen in our woods. In its form, dimensions, activity, and fecundity, it resembles the weasel, but is rather larger ; one of them weighed fourteen ounces. Its colour is a bcautiful white: 'The tail is tipped with a beautiful black. Some of these animals have a stripe of dark brown, or mouse colour, extending along the back, from the head to the tail ; the other parts being perfectly white. This little, brisk, sprightly and beautiful animal, has the most fine and delicate fur, that can be imagined; and the animal itself is one of the greatest beautics of nature.

Of the SCutrRel we have four or five species ; grey, black, red, striped, and fying.

THE Grey Squirrel is the largest, and most common. "This squirrel is about thirteen or fourteen inches in length, with a large bushy tail, as long as the body. It is of a beautiful silver grey colour, and has a fine soft fur. Its nest is in the crotch, or hollow of a tree; its food, corn, acorns, and nuts. It lays up a store of these provisions against winter, in the hollow of old trees. The female bears her young in the spring, and has generally three or four at a 
birth. The largest of these grey. squirrels, when they are fully fatted in the fall, weigh three pounds and an half.

'Tн E Black Squirrel resembles the former in every respect, but its colour, and size. It is wholly black, without any change in its colour, at any time of the year. Its size is something less than that of the grey squirrel: the largest I have known, weighed but two pounds and an half.

Tin E Red Squirrel does not appear to differ from the black, in any other particular, but the colour.

Tne Striped Squirrel is smaller than either of the other. The largest of these does not weigh more than nine or ten ounces. This squirrel digs a hole in the ground, for the place of his residence. He provides a store of nuts, acorns, and corn, against winter. These are carefully deposited in his nest; and he resides in the earth cluring the severity of the season.

Tin Flying Squirrel is the inost curious, and beautiful of all; and of the same size as the striped onc: This squirrel has a kind of wings, $b_{j}$ which he will pass from one tree to another, at the distance of thirty or forty fect. None of our animals have a more fine or delicate fur, than this little squirrel. He feeds on the burls, and seeds of regetabics; and generally has his nest in decared, and rotten trces.

The Mole, Shrew Mouse, Ground Mouse, and Frem Mouse, are to be found in this part of America : they are so small, and well known, that they do not require a particular description. The hunters inform me, that 


\section{HISTORY OH VERMONT. 113}

there are several kinds of mice to be found in the woods, which have not been described. The grey rat, the black rat, and the water rat, have now become common; though but a few years since, they were not to be found in any part of the state.

The quadrupeds which have been described, are to be found only upon the land. There are others of an amphibious nature, which live upon the land, or in the water ; these are to be found in the rivers, ponds, and lakes.

$\mathrm{ONE}_{\mathrm{NE}}$ of the most sagacious and useful of these, is the BEAVER. On account of his natural constitution and instincts, his social nature, the works he performs, and the uses to which he is applied, the beaver is the most extraordinary of all our animals, and descrves a more particular description.

$\mathrm{T}$ н $\mathrm{E}$ American bcaver is between three and four fect in length, and weighs from forty to sixty pounds. His head is like that of a rat, inclined to the earth; his back rises in an arch between his head and tail. His teeth are long, broad, strong, and sharp. Four of these, two in the upper, and two in the under jaw, are called incisors. These teeth project one or two inches beyond the jaw, and are sharp, and curvcd, like a carpenter's gouge. In his fore feet the toes are separate, as if designed to answerthe purposes of fingers and hands: His hind feet are accommodated with webs, suited to the purpose of swimming. His tail is a foot long, an inch thick, and five or six inches broad: It is corcred with scales, and with a skin similar to that of fish. 
In no animal dees the social instinst and habit appear more stronor or universal, than in the beirer. Theresocrer a number of these animals are found, they inmediately associate, and combine in society, to pursue their common business, and welfare. Frery thing is done, by the united counsels, and labours, of the whole communitr. "lheir societies are generally collected together, in the months of Junc and July; and ther numbers when thus collected, frequently amount to two or three hundred; all of which, immediately engage in a joint efort, to promote the common business and safety of the whole society; apparcnty acting wnder a common inclination, and direction. When the benuer is found in a solitary statc, he appears to be a tinid, inactive, and stupid anmal. Instead of attempting any impotant enterprize, he contents himself with diging a hole in the earin for safety and concenincht. His genius scems to be depressed, his spirits broken, and crcry thing enterprizing is lost in an attention to personal safety; but he nerer locses his natiral instinct to find or form a pond. When combined in sceiety, his disposition, and poryers assune their natural divection, and are exerted to the highest advantage : Frery thing is then undertaken, which the beaver is capabie of perioming.

The society of bearers seems to be resulated and governed, aliogether by natural disprusition,

* A young beaver was tamed in the southem part of this stare. He became quiet, inoffensive, and withnut any disposition lo depar: But was most of all pleased, when he was at work, forming a kam, in a small sticam near the house. 
and lavss. Their socicty, in all its pursuits and operations, appears to be a society of peace and nututul affection; guicled by one principle, and under the same direction. No contention, disagrreement, contrary interests, or pursuits, are ever seen among them; but perfect harmony and agreement, prevails through their whole dominions. The principle of this union and regulation, is not the superior strenghe, art, or activity of any individual : Nothing has the. appearance, among them, of the authority, or inintence of a chief, or leader. Their association and management, has the aspect of a pure and perfect democracy; founded on the principle of perfect equality, and the strongest mutual attachment. This principle seems to be suficient to preserve the most perfect harmony, and to regulate all the proceedings of their largest societies.

WHEN these animals are collected together, their first attention is to the public business and affairs of the society, to which they belong. The beavers are amphibious animals, and must spend one part of their time in the water, and another upon the land. In conformity to this daw of their natures, their first employment is to find a situation, convenient for both these purposes. With this view a lake, a pond, or a running stream of water, is chosen for the scene of their habitation, and friture operations. If it be a lake, or a pond that is selected, the water is always of such depth, that the beavers may have-sufficient room to swim under the ice; and one, of which they can have an entire, and undisturbed possession. If a stream of water is 
chosen, it is always such a stream, as will forns a pond, that shall be every way convenient for their purpose. And such is their foresight and comprehension of these circumstances, that they never form an erroneous judgment, or fix upon a situation that will not answer their designs and convenience. Thein-next-business, is to construct a dam. This is always chosen in the most convenient part of the stream; and the form of it, is either direct, circular, or with angies, as the situation and circumstances of the fiater and land, require: And so well chosen is both the place, and the form of these dams, that no engineer could give them a better situation and form, either for convenience, strength, or duration. The materials of which the dams are constructed, are wood, and earth. If there be a tree on the side of the river, which would naturaly fall across the strean, several of the beavers set themselves with great diligence, to cut it down with their teeth. Trees to the bigness of twenty inches diameter, are thus thrown across a stream. They next, giaw of the bran. ches from the trunk, that the tree may assume a lerel position. Others, at the same time, are cutting down smaller trees, and saplings, from one to ten inches diameter. These are clit in. to equal and convenient lengths. Some of the beavers drag these pieces of wood to the side of the river, and others swim with them to the place, where the dam is to be built. As many as can find room, are engaged in sinking one end of these stakes; and as many more in raising, fixing, and securing the other end. While many of the beavers are thus labouring upon 
the wood, others are equally engaged in carry. ing on the earthern part of the work. The earth is brought in their mouths, formed into a kind of mortar with their feet and tails, and spread over the vacancies between the stakes: Saplings, and the small branches of trees, are twisted and worked up with the mud and slime; intil all the vacancies are filled up; and no crevice is left in any part of the work, for the water to find a passage through. The magnitude and extent of the dams, which the beavers thus construct, is much larger than we should imagine was possible to be effected, by such labourers, or instruments. At the bottom, the dam is from six to twelve feet thick; at the top, it is generally two or three feet in width. In that part of the dam, which is opposed to the current, the stakes are placed obliquely: but on that side where the water is to fall, the stakes are placed in a perpendicular direction ; and the dam assumes the same form, and position, as the stakes. The extent of these works, is from fifty to an hundred feet in length ; and always of such an height, as to effecr' the pur. poses they have in view. The ponds which are formied by these dams, are of all dimensions: from four or five; to five or six hundred acres. They are generally spread over lands abounding with trees; and bushes, of the softest wood: Maple, birch, alder; poplar; willow, \& $\mathrm{c}_{\text {. The }}$ better to preserve their dams, the beavers al. ways leave sluices, or passages near the middle, for the redundant waters to pass off. These sluices are generally about eighteen inches in width, and depth ; and as many in number, as the waters of the stream generally require.

พOL. I. P. 
WHE is the public works are completed, thicir domestic concerms and rifuirs next enguge their attention. 'The dam is 110 sooncr completed, than the beavers separate into small bedies, to build calbins, or houses for themselves. These houses are buit upon pis:s, aloug the borckers of the pond. 'They are of an oval form, rescmbing the construction of an harcock ; and they vary in their dimensions, fiom four to ten feet in diameter, according to the number of families they are designed to accommodate. They ate always of two stories, generaily of three, and sometimes they contain four. Their walls aie frem two to thise fect in thickness, at the botton; and are formed of the same matcrials as their dans. "They rise perpendicularly a few fect, then assume a curved form, and terninate in a dome or vault, which answers the pur. pose of a roof. These edlifices are buitt with much solidity, and neatness: On the inward side, they are smooth, but rough on the outsicic; always inperictrabic to the rain, and of sullicient strength to resist the most impetuous winds. The lower story is about two feet high : the sccond story has a floor of sticks, covered with mud : the thind story is divided from the second, in the same manner, and terminated by the roof raised in the form of an arch. Whrough each foor, there is a communication; and the upper floor is always above the level of the water, when it is raised to its greatest height. Fach of these huts have tro cloors; one, on the land side, to enable them to go out and procure provisions by land; another ander the water, and below where it freezes, to 


\section{HISTORY OF VERMONT. IIS}

preserve their communication with the pond. If this, at any time begins to be covered. with ice, the ice is immediately broken, that the communication may not be cut off with the air.

In these huts, the families of the beavers have their residence. 'The smallest of their cabins, contain one family, consisting generally of five or six beavers; and the largest of the. buildings will contain from twenty to thirty. No socicty of animals, can ever appear better regulated, or more happy, than the family of beavers. The male and the female, always pair. Their selection is not a matter of chance, or accident; but appears to be derived from taste, and mutual affection. In September, the happy couple lay up their store of provisions, for winter. This consists of bark, the tender twigs of trees, and various kinds of soft wood. When their provisions are prepared, the season of love and repose commences: And during the winter they remain in their cabins, enjoying the fruits of their labours, and partaking in the sweets of domestic happiness. Towards the end of winter, the females bring forth their young, to the number of three or four. Soon after, the male retires to giather fish, and vegetables, as the spring opens; but the mother remains at home, to nurse, and rear up the off. spring, until they are able to follow their dams. The malc occasionally returns, but not to tarry, until the fall of the year. But if any injury is done to their public works, the whole society are soon collected, and join all their forces to repair the injury, which affects their commonwealth. 
NotHING can exceed the peace and regularity, which prevails in the families, and through the whole commonwealth of these animals. No discord or contention ever appears in any of their families. Every beaver knows his own apartment, and store house; and there is no pilfering or robbing from one another. The male and the female are mutually attached to, never prove unfriendly, or desert one another. Their provisions are collected, and expended, without any dissention. Each knows its orin family, business, and property; and they are never seen to injure, oppose, or interfere with one another, The same order and tranquility prevail, through the commonwealth. Different societies of beavers, never make war upon one another, or upon any other animals. When they are attacked by their enemies, they instant. ly plunge into the water, to escape their pursuit: And when they cannot escape, they fall an easy sacrifice.

In the arts necessary for their safety, the beavers rise to great eninence. The situation, direction, form, solidity, beauty, and durability. of their dams, are equal to any thing of the kind, which has ever been performed by man. They always form a right judgment, which way the tree will fall : And when it is nearly cut down, they appoint one of their number, to give no. tice by a stroke of his tail, when it begins to fall. " 'Vith their tails, they measure the lengths of their dams, of the stakes they are to use, of a breach that is made in their works, and of the length of the timber that is necessary to repair it. When an enemy approaches their domin. 
ions, the beaver which makes the discovery, by striking on the water with his tail, gives notice to the whole village of the approaching danger; and all of them instantly plunge into the water. And when the hunters are passing through their country, some of their number appear to be centinels, to give notice of their approach.

$T_{H E}$ colour of the beaver is different, accor ding to the different climates, which they inhabit. In the most northern parts, they are generally black; in Vermont they are brown; and their colour becomes lighter as we approach towards the south. Their fur is of two sorts; all over their bodies. That which is longest, is generally about an inch long, but on the back. it sometimes extends to two inches, gradually shortening towards the head, and tail. This part is coarse, and of little use. The other part of the fur consists of a very fine and thick down, about three quarters of an inch long, so soft that it feels like silk, and is that, which is used in manufactories. Castor, of so much use in medicine, is produced from the body of the beaver. It is contained in four bags, in the lower belly.

TH E largest of these animals; of which I have any certain information, weighed sixty three pounds and an half: But it is only in a situation remote from, and undisturbed by the frequent appearances of men, that they attain their greatest magnitude, or their highest perfection of society. The beaver has deserted all the southern parts of Vermont, and is now to be found only in the most northern, and uncultiva. ted parts of the state. 
The Muskrat scems to be a smaller lind of bcarer, resembling it in every thing but its tail. This is also an amphibious animal, and forms a cabin of sticks and mud, in some stagnant water ; but is less fearful of the approaches of men, and affords a very strorig musk. These animals are to be found, in very considerable numbers, in our creeks, and lakes; but are much less numerous, than they were formerly. The mustrat, in this part of America, is about fiftcen inches in length; the greatest magnitude I have known is five pounds and three quarters of a pound. A litter of these muskrats, will fiequently amount to four, five, and sometimes six.

ANOTHER of Our amphibious animals, is the MIN E. It always resides in the neighborhood of rivers, ponds, or lakes ; and provides a place of residence, by burrowing into the earth. The mink is about trenty inches in length; his legs are short, his colour brown, and his fur is nore valuable than that of the muskrat. One of the largest which I have known, weighed four pounds and one quarter of a pound. The female produces two or three, at a birth.

Tif $\mathrm{OTT}_{\mathrm{T} \text { T }}$ is a voracious animal, of great activity and ficrceness. When it is fully grown, it is five or six feet iong; with sharp and strong tecth; short legs, and membranes in all his fect ; and fitted either for running or swimming: The otter cxplores the rivers and ponds in scarch of fish, frogs, water rats, and other smail aninals: And when these are not to be had, lie ves on the boughs and bark of young, or puatic trees. He has generally been ranked 


\section{HISTORY OF VERMONT.}

among the amphibious animals, which can live either in the air, or water; but he is not pro. perly an amphibious animal, for lic cannot lire without respiration, any more than the land animals. The female is in heat in the winter, and bears her young in the month of March; the litter generally consists of threc or four. The fierceness and strength of the old otters, is such, that the dog can seldom overcome them: And when they cannot escape, they will attack the hunter with great rage. The colour of this animal is black, and its fur is much esteemed. The otter formerly abounded very much in our creeks, and rivers ; and especially in those, which cmpty themselves into Lake Champlain : On this account, one of them still bears the name of Ottercieck; but the animal is now become scarce. The largest otter, of which I have a particular account, weighed twenty nine pounds and an half.

To this account of the quadrupeds of Vermont, I shall subjoin some reffections on the general state of these animals in America.

The entmeration very imperfect. Our ac. counts of the quadrupeds in this, and in every part of America, must be viewed as greatly imperfect. The descendants of Europe have settled along the sea coasts, and they have penetrated to the lakes, and most of the navigable rivers. But the internal parts of S. America, are but littleknown: Andall that immense tract of country in N. America, which lies to the north, and to the west of the lakes, is wholly unexplored. It is not to be cloubted, but these extensive re. gions, abound with quadrupeds: Of what spe 


\section{NATURAL AND CIVIL}

cies, and how numerous, we cannot so mucli as conjecture. When the cointry shall be fully explored, and then able naturalists shall have visited and examined the internal parts, the his. tory of the animals of America, may be brought to some perfection; but it is far from it, at present. All tife animals which have been enu. merated, are only those which are frequently found, in a small part of the continent. That an animal of great and uncommon magnitude, has existed in North America, and in Siberia, is certain from the bones of the animal which yet remain: On the bonks of the Ohio, and in many places further north, tusks, grinders, and skeletons, of an enomous size, are to be found in great numbers. Some of them lie upon the surface of the ground, and others are five or six feet below it. Some of the tusks are near seven feet long, one foot and nine inches at the base, and one foot near the point; the cavity at the base, nineteen inches deep. From the size and thickness of these bones, it is certain that they could not belong to the elephant; but denote an animal five or six times as large, and of the carnivorcus kind. We have the testimony of the Indians that such an animal still exists in the western parts of America. And it would be contrary to the whole economy of nature, to suppose that any species of her animals, is become extinct. "This animal must formerly have been numerous; at those places, where their bones are found in such numbers. The prolability is, as the mcans of subsistence were de. stroyed, they removed further to the westward. But until those parts of America shall be ex- 


\section{HISTORY OF VERMONT. 123}

Wlorech, little information is to be expected conEerning this animal of the most enormous bulk: And we may as well call it the Mummoth, as by any other naine; or the Pseudo Elephant, as it has been named by Dr. Hunter. From this, and from many other considerations, it appears that the enumeration of the American quadrupeds, is extremely imperfect.

ORIGIN. The animals which are spiead over the face of the earth, are fitted by nature, for the climate and country; where they reside. No animal, or regetable, has a constitution a. dapted to every-country: And there are none, but what are suited to some particular part of the earth, where they will arrive to their greatest perfection. A camel is peculiarly fitted, for the burning sands of Arabia: And the reindeer will flourish the best in Lapland, Hudson's Bay, and those northern countries, where the cold is the most intense. The origin therefore of different quadrupeds, is to be sought in those climates, that appear to be the best adapted to their growth and multiplication. There are animals in the torrid zone in America, which are never found in any other part of the earth. This is the case with the Tapyr of Brasil, the Puina and Jugiar, the Lama and Paci. These animals have never wanderec into any other part of the globe: They are therefore to be esteemed indigenous, or natural to the hot climates of America. The same is the case with the animals of the torrid zone in Asia, and Africa. The elephant; and rhinoceros, are productions of Asia. The deserts of Zaara and Biledulgerid in Africa, may be termed the native country of voL. I. 
lions, tygers, and panthers. No part of the climate of America is so intensely hot, or sandy, ats to render it the proper country for the pro. duction or increase of animals, so fierce and noxious. These quadrupeds of hot climates, have never wandered from the one country, to whe other : Not because they could not find a jassage, but because they must have passed through a climate, the cold of which, being such as they could not endure, was an effectual bar to their passage. There are other quadrupods which are common to America, to the north of Asia, and to Europe. Of this kind are the bufialo, white bear, carabou, black bear, eik, moose, red deér, fallow deer, wolf, roe, gilution, lynx, wild cat, beaver, badger, red fox, grey fox, black fox, otcex, monax, vison, porcupine, rartin, water rat, rreasel, ermine, flying squirrel, mole, and mouse. If we add the unknown animal, which we have called the mam. moth, the number of those quadrupeds which are common to both hemispheres, will amount to thirty. All of them, are the quadrupeds of cold countrics; fitted by nature to that climate, through which the passage must have been, from the one count:y to the other. The original situation therefore of these quadrupeds, must have been a cold conntry. But whether they passed from the northcastern parts of Asia, into America; or whether they issued from the northwest parts of America, into Asia; we have no way to determine. The probability is equal, upon cither supposition. All that we can determine is, that they were originally the quadrujeds of a cold climate. 


\section{HISTORY OF VERMONT.}

Migration. Animals of every kind when oppressed by hunger, harassed by their enemies, or when they can find a more comfortable situation, will migrate from one country to another. Their migration when chosen and voluntary, is always with a view to better accommodations; to a situation more favourable for food, growth, and multiplication. Directed by the hand of nature, thcir natural progress is not to a worse, but to a better situation. They do not leave their own comntry, to settle in one less suited to their subsistence, and increase; but to acquire greater advantages; an increase of food, numbers, and vigour. Whether the migration of quadrupeds then was from Asia, or from America, there can be no doubt, but that they found in the country to which they repaired, a climate, soil, and means of subsistence, equally favourable to them, as those which they left. Had there been any very great difference in the provisions, and accommodations of nature, in either country, the quadrupeds that could easily migrate, would not have remained, for any considerable time, common to them both. Nothing therefore can be less probable, or more contrary to the laws, tendencies, and operations of nature, than the European idea first introduced by $M$. Buffon, that the quadrupeds of Europe migrated into a country in A. merica, where every thing was adapted by nature, to their diminution, degradation, and decrease. Had not the northern parts of Asia, and America, been well suited to the subsistence, vigour, and increase of these quadrupeds, there would not have been any voluntary migration, 
from the one to the other; nor would these animals have remained, for so long a time, com. mon to them both.

SPECIES. How far nature has procecied in the production of quadrupeds, we have not as yet, sufficient information to determine. There may be many species, yet unknown, in those parts of the earth which have not been explorcd : Nor is the cinumeration complete, in those countries which are known. The most that has been done in this branch of natural history, is to be found in the celcbrated work of IM. Buffon. As the result of his inquiries and in. formation, this able philosopher concludes that the whole number of quadruped:, which are epread orer the face of the earth, will form abont two hundred different species or kinds. \%ै Of these, one hundrcd are found in America, and about seventy five are peculiar to it. If the power, the force, or the vigour of animatcil nimiture, is to be estimated by the species of quadrupeds, which difierent countries contain, the conclusion will be, that nature has acted with the greatest rigour and energy in America. In the difterent climates in Amcrira, nature has produced seventy fire species of quadrupeds : the number of those which are peculiar to the other parts of the globe are one bundred. The dimensions of America, compared with the dimensions of Asia, Africa, and Europe, by the computation of the modern 8 cographers, are as one handred and forty one to twe hundred and forty nine.t The ratio of one

* Vol. IX. 4T.

+ Guthric's Gcography, \&. 25. 
hindred and forty one to two hundred and forty nine is the sainie as seventy five to one liundred and thirty two. And so many species should be found, in the other parts of the globe, to preserve an cquality : But this is thirty two more, than nature has produced. In respect then to the different species of quadrupeds, if we are to judge by any enumeration which has yet been made, the greatest force and vigour of nature is found in America.*

Magnitude. The magnitude which anyanimal will attain, seems to depend much upon its original constitution, the climate, and proper nourishment. In the original constitution of eacl animal, the Creator seems to have established certain laws, respecting its form, gencration, expansion, and support. 'The proper magritude of the animal, is therefore assigned by nature, to each species: In this way, the original limits are fixed; above, or below which, no individual of that species shall rise, or fall. Within these limits, those variations may take place, which we mean to express, when we call the animal great, or small. But no circumstance will reverse the laws of nature, enable the different species of animals to exchange their proper form, and magnitude; to debase the ox into a mole, or to exalt the mole to the size of the $0 x$. Nature has also fitted each quadruped for the climate, in which it was originally placed; and in that climate only, will it

THE enumeration of quadrupeds seems to belto imperfert to 2ford any accurate calculations of this kind. According to M. Buffon's satest conclusions, in his Eponues de la Nature, there are :hree hundred species of quadrufeds. America accoriing to the 4 bbe Clavigero, coseirirs about one half cî these. 
attain its proper perfection. The lion would lose its fierceness, and perish, if it was removed to Lapland ; and the reindeer would diminish, and die, if it was carried to the sandy deserts of Africa. In those climates only, to which nature has adapted cach animal, will it attain its greatest magnitude, and most perfect form. The animal, to which nature has thus assigned its proper constitution, and climate, must be preserved and supported by proper food, or nourishment. A deficiency here, will bring on lcanness, impotency, a diminution of size, and a gradual waste and consumption of the whole species. But when the climate, and the food, are both suited to the natural constitution of the animal, their joint influence will produce the greatest size or magnitude, that species will admit.

By comparing the magnitudes of such quad. rupeds in Europe, and in America, as are common to both, and cierive their support from the hand of nature, we shall of consequence have another comparative view of the vigour and force, to which animated nature arrives, in eacd country. Several of those quadrupeds, whose weight has been ascertained in Vermont, $\mathbf{M}$. Buffon has given us the weight of in Europe. Phey are these,

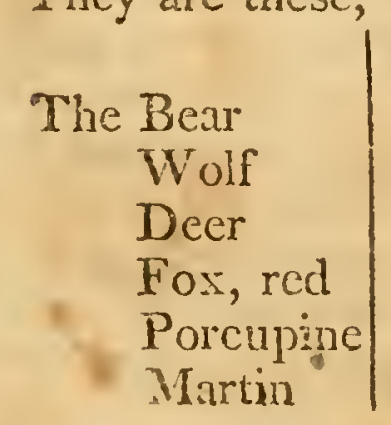

Weight in Europe.

$\begin{array}{rr}\text { Ib. } & \mathrm{cz} \\ 153 & 7 \\ 69 & 8 \\ 288 & 8 \\ 13 & 5 \\ 2 & 2 \\ 1 & 9\end{array}$
Weight in Vermont.
1b. ox. 456 92 308 20 16 54 


\section{HISTORY OF VERMONT. 13L}

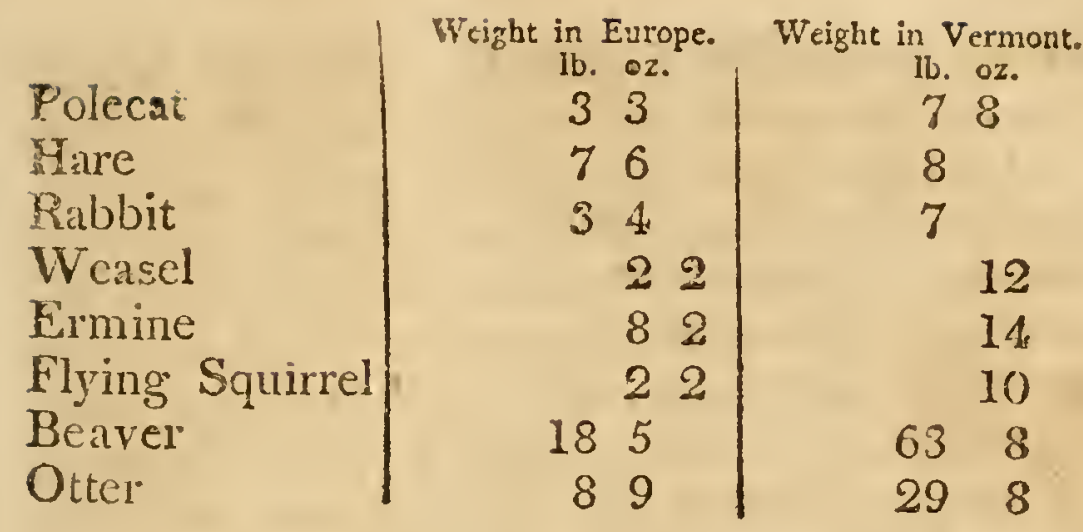

From this comparison it appears, that every one of these animals, is larger in America, than it is in Europe. The inference is clear, and decisive: It is in America, and not in Europe. that these quadrtipeds of a cold climate, attain their greatest magnitude, and highest perfection.

If the comparison should be made, between the quadrupeds of the torrid zone, the reverse will be found to be the case. The elephant, the rhinoceros of Asia, are much larger than the quadrupeds of Peru and Brasil. The truth is, America is the most favourable to the productions, and growth, of the quadrupeds of cold climates: Asia is the most favourable to the productions, and growth of the quadrupeds of a hot climate. But the greatest of all animals, the Mammoth, was not an animal of the torrid, but of the temperate zone; and was the pro. duction of both countries, of Asia, and of A. merica.

Temper and Disposition. Most animals have a particular disposition and character assigned to them by nature, indelibly fixed, and which distinguishes the whole species. Thus some are naturally ferce, sanguinary, and car: 
nivorous; while others are mild, temperate, and gentle: And all of them, are not a little infuenced, by the climate they inhabit. In the hottest climate, and in the burning sands of Africa, the most ravcnous, and the fiercest animals abound: The lion, the tyger, and the panther, are there; in their greatest size, their largest numbers, and most extreme fierceness: In such places, the vegetables also contain their strongest qualities; the drugs, perfumes, and poisons, are the most active, subtle, and powerful. In America every thing in her vegetables; fruits, and animals, is more mild and temperate. The quadrupeds that most abound, are the la. ma, paco, bufalo, elk, deer, for, beaver, hares, rabbits, and squirrels ; animals, marked vith a mildness, and gentleness of character. Those that are the most fierce, the bear, the wolf, the wild cat, the otter, the congar, or tapyr, are sel. dom known to make their attacks upon men, unless they are impelled to it by extreme hunger, provocation, or self defence. It was not therefore with the most ficree and ravenous animals, that America abounded: Her quadrupecls were of a more mild, and temperate disposition. To these, her climale gives the greatest size, the highest perfection, and the largest increase.

Increase and Multiplying Powero The increase and multiplying porrer of animals, is derived partly from nature, and partly from situation, and other circumstances. Nature has made those animals which are the most large, fierce, and noxious, the least apt to multiply. 'The smaller and more useful any quadruped is, the more rapid is its increase. All of 
them bring forth their young; at that season of the year, when nature has made the most suitable and anple provision, for their food and support. And then they multiply with the greatest rapidity; when they are the least molested by man. But whatever be their multiplying power, it would require a long period of time, before they would arrive at that increase of numbers, in which their progress would be checkcd, by the want of food. They would naturally spread over the whole continent; be. fore they arrived to such a state. This they had done in every part of America, when it was first discorered by the Europeans : Every part of the continent, fitted for their nourishment and growth, abounded with them. How far nature may proceed this way, of what is the greatest number of quadrupeds, that the uncultivated state of any country will support, we have no observations to determine. But it seems probable, that the maximinn had already taken place; that America contained her full number of quadrupeds. No observations or phenomena; denote that there has been any in. crease of these animals; in the uncultivated parts of the continent, since its first discovery ; or that they erer were more thick and nunerous, in any other part of the globe. How long a period nature required to advance to this state in America, "we have no data to determine. But if we may judge of the energy' with whick she acts, from the effects of her multiplying power, the conclusion will be, that in no country has she displayed gireater powers of fecundi. ty than in America. These circumstancs,

$$
\text { VOI. I, } \mathrm{R}
$$


denote an high antiquity, in the origin of the American quadrupeds; and a great fertility in that climate and country, in which they have attained their greatest numbers, their greatest magnitude, and their greatest fecundity.

\section{B I P D S.}

THE Birds which abound in every part of Anerica, make a curious and beautiful part of her natural history. Catesby has given an elegant description of the birds of Carolina. Belknap has furnished a good catalogue of those of Newhampshire. Most of the birds which have been mentioncd by these authors are to be found in all the northern states. As we approach further towards the north, a great number and variety of water fow are to be found, in the lakes, rivers, and harbours, which have never been described, or classed.

Is Vermont we have most of the birds, which are known in the inland parts, and lakes of the northern climates. Some of them seem to be fitted by nature, to endure all the sererity of our climate, and are to be seen in the coldest weather of our winters. Of this kind, are The Crow. Corvus Cornix:

Hawk, forked tail. Falco Furcatus.

Owl. Strix Asio.

Blue Jay. Corvus Cristatus.

Snowbird. Emberiza Hyemalis.

Partridge. Perclix Sylvestris.

Woodpecker, red headed. Picus Capite toto rubr.

THERE are several other birds, the robbin, blackbird, lark, snipe, bluebird, \&c. which are 


\section{HISTORY OF VERMONT. 135}

seen as soon as the snow goes off, in the spring. They are not seen in the winter, but they are found late in the fall. From their late and ear. ly appearance, it is not improbable that some of them may tarry here through the winter.

THOSE which are esteemed birds of passage, with the usual times of their appearance, and departure, are

Timeofap- Departure pearance.

The Snowbird. Emberiza hyemalis Nov. 20. ipril r. Wild goose. Anas canadensis. March is Nov. 230 Wild Pigeon. Columba migratoriamarch 20. Ooct. I0. House Swallow. Hirundo cauda acculeata Barn Swallow. Hirundo Rustica. Ground Swallow. Hirundo Riparia. Black Martin. Hirundo Perpurea,

The SN ow в I D D is a beautiful, active, sprightly, little animal. They are generally of a grey colour, and less than a sparrow. Flocks of them appear, as soon as the snow begins to fall in any considerable quantity; and generally a day or two before. 'They perch on the spires of vegetables above the snow, on the bushes, and trees; and collect on the spots of bare ground. In the most severe storms of snow, these birds appear to be the most active and lively. They feed on the seeds of vegretables, and are extremely fat and delicious; but they are too small to be molested on this account. They seem to be of different colours, black, white, and grey; but they all disappear as soon as the snow goes off.

The Wild Goose, from the beginning of April, to the middle of Norember, reside 
chichy in the more northern, and northeasterly parts of America. In those parts they produce their young, and are to be found in the rivers and hirbours, in immense numbers. In November they come in large flocks from the north, and northeast, and pass off to the southwest. In March and April, they return from the southwest in a contruy direction, and go back to their summer habitation. These focks ficquently consist of fify or sixty' : They fly at a great height, and appcar to observe great regularity in their passage. They somctimes follow one another in a straight line, but are more seneraily dratn up in the form of a redgre; and appear to beled by one of the strongest, and most active. While the kecp together, they seen to understand their course perfectiy well ; but if by any means their order is broken, and the flock dispersed, several of them rander out of their course, appear to be perplexed, descend to the earth, and are often kilded or taken. When tamed, they will join with a lock of domestic geese; but at the usual times of migration, are rery apt to join any flock, which approaches near to them, in their passage.

IN the $W_{\text {ind }}$ Picrox, the muitiplying power of nature acts with geat force and vigour. The male and fomalc aurays pair : they sit alternately upon the esgs, and grencrally hatch but two at a time; but this is repeated several times in a scason, The accounts which are giren of the number of pigeons in the uncultirated parts of the country will appear almost incredible to those who have never seen their 


\section{HISTORY OF VERMONT. $13 \overrightarrow{\mathrm{z}}$}

nests. The surveyer, Richard fiazen, who ran the line which divides Massachusetts from Vermont, in 174.1, gave this account of the appearances, which he met with to the westward of Connecticut river. "For three miles together the pigeons' nests were so thick, that five hundred might ivive been told on the beech-trees at onc time; and could they have been counted on the hemlocks, as well, I doubt not but five thousand at one turn round." * The remarks of the first settlers of Vermont, fully confirm this account. The following relation was given me, by one of the carliest settlers at Cendon: "the number of pigeons was immense. Twen. ty five nests were frequently to be found on one tree. The carth was covered with these beech trees, and with hemlocks, thus load. ed with the nests of pigeons. For an hundred acres together, the ground was covered with their dung, to the depth of two inches. Their noisc in the evening was extremely troublesome, and so great that the traveller could not get any sleep, where their nests were thick. About an hour after sunrise, they rose in such numbers as to darken the air. When the young pigeons were grown to a considerable bigness, before they could readily fly, it was common for the settlers to cut down the trees, and gather a horse load in a ferw minutes." This account may appear improbable to those who have not observed the fecundity of nature. But it falls much short of what has been observed in the state of Ohio. The following is from Harris's

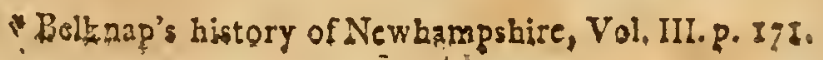


account of that state p. $179,180$.

"The vast "flights of pigeons in this country seem incred"ible. But there is a large forest in Water"ford, containing several hundred acres, which "las been killed in consequence of their light"ing upon it cluring the autumn of 1801 . "Such numbers lorged upon the trees thrat "they broke off large limbs; and the ground be"low is corered, and in some places a foot "thick, with thei" dung, which has not only " silled all the undergrowth, but all the trees "are dead as if they had becn girdled."

The above, he adds is confirmed by a letter from the Rev. Mr. Story, dated Alarictia, June 3, 1803. "I have risited two pigeon-roosts, " and have heard of a third. "Those I have seen " are astonishing. One is supposed to cover " one thousand acres; the other is still larger. "The destruction of tinber and biush on such " large tracts of iand by these small animals is "almost incredible. How many millions of " then must have asscmbled to effect it ! cspe" cially as it was done in the course of a ferr "weeks." The settiement of the country has since set bounds to this luxuriancy of animal life ; diminished the number of these birds, and drove them further to the northward.

WE have four species of SWALLOWS in this part of America. 1. The house swallow. This may be readily distinguished from the rest, by the greater forkedness of its tail. It has also a red spot upon its forehead; and under its chin. This species build their nests in chimneys. Their nests are made of small sticks, cemented together, with a kind of gum, and 
mud ; they are covered or arched over the tops, and the aperture is on one side. These swallows appear the earliest of any, in the spring : And a few days before their departure in the fall, they associate on the tops of buildings, dry trees, and bushes, as if about to depart in companies. 2. The barn sivallow. The size of this, is rather less than that of the other ; and the tail is not. forked so much. These swallows build their nests in barns and out houses; and they are formed of grass straw, and feathers. Their eggs are speckled, of a dark brown and white. It is called the barn swallow from the place in which it generally builds its nest. 3 . The ground swallow. This is the smallest of the whole species. These swallows form a hole in sandy banks, and on the sicies of rivers, of eighteen or twenty fou incles in length. Their nests are made at the extremity of these holes, of straw and feathers, laid together in a loose and careless manner. Their eggrs are perfectly white. The holes in which they are laid, are designed only for their nests: None of the swallows ever remain in them, during the winter. 4. The black martin. This is the largest of all our swal'iows. They build their' nests under the eaves of houses, in the secret or retired places of out houses, and old buildings. Their nests are made of straw and feathers. 'They arrive the latest, and disappear the soones, of any of the swallows, which visit us.

TuE usual times of the appearance and disappearance of these birds, serve to mark the tem. perature of the climate, with as much precision, 2s any of the phenomena of nature. But they, 
do not seem to be properly birds of passage. At Danty in this state, the inhabitants report, that some of them were taken out of a pond in that town, some years ago. A man was em. ployed in the winter, to procure the roots of the pond lily, for medicinal purposes. A.rnong the mud and roots which he threw out, several swallows were found inclosed in the mud ; alive, but in a torpid state. The account is not doubted among the inhabitants; but I have not the testimony of any persons who saw these swallows. It has been doubted by some able naturalists, whether it is possible for the swallow to live in such a situation. I saw an instance, which puts the possibility of the fact beyond all room for doubt. About the year 1760, two men were digging in the salt marsh at Cambridge, io Massachusetts: On the bank of Charles' river about two feet below the sur. face of the ground, they dug up a swallow, wholly surrounded and covered with mud. The swallow was in a torpid state, but being: held in their hands, it revived in about half an hour. The place where this swallow was dug up, was every day corered with the salt water; which at every high tide, was four or five feet deep. The time when this swallow was found, was the latter part of the month of February: but the men assured ine, they had never found any other swallows in such a situation. The species called the house or chimney suallow; has been found during the winter, in hallow erees. At Middlebury in this state, there was a large hollow elm, called by the people in the vicinity the swallow tree. From a man who, 
for several years, lived within twenty rods of it, I procured this information : He always thought the swallows tarried in the tree through the winter, and avoided cutting it down, on that account. About the first of May, the swallows came out of it, in large numbers, about the middle of the day; and soon returned. As the weather grew warmer, they came out in the morning with a loud noise, or roar, and were soon dispersed : About half an hour before sun down, they returned in millions, circulating two or three times round the tree, and then descending like a stream, into a hole about sixty feet from the ground. It was customary for persons in the vicinity, to visit this tree, to observe the motions of these birds : And when any persons disturbed their operations, by striking violently against the tree, with their axes, the swallows would rush out in millions, and with a great noise. In November, 1791, the top of this tree, was blown down, twenty feet below where the swallows entered. There has been no appearance of the swallows since. Upon cutting down the remainder, an immense quantity of excrements, quills and feathers were found; but no appearanice or relicks of any nests.

Another of these swallow trees, was at Bridport. The man who lived nearest to it, gave this account: The swallows were first observed to come out of the tree, in the spring ; about the time, that the leaves first began to appear on the trees. From that season, they came out in the morning, about half an hour af- 
ter sunrise: They rushed out like a stream, as big as the hole in the tree would admit, and as. cended in a perpendicular line, until they were above the height of the adjacent trees; then as. sumed a circular notion, performing their rev. olutions two or three times, but always in a lar. ger circle, and then dispersed in erery direction. A little before sundown, thcy returned in immense numbers, forming sererial circular motions, and then clescended like a stream into the hole, from whence they came out in the morning. About the middle of September, they were seen cntering the tree, for the last time. These birds were ail of the species called the house or chimney swallow. The tree was a large hollow elm, the hole at which they entered was about forty feet above the ground, and about nine inches diameter. The swallows made their first appearance in the spring, and their last appearance in the fall, in the vicinity of this tree; and the neighboring: inhabitants had no doubt, but thit the swallors continued in it during the winter. A few years ago, a hole was cuit at the bottom of the tree : From that time, the swallows have been gradually forsaking the tree, and have now almost deserted it. The following account from Nathan Rumscy, Esq. of Frbburdton is more circumstantial and conclusive. "Sometime in the month of March, A. D. 1786, when the snow was deep on the ground, I was making sugar in the town of Hubbariton, with the assistance of some boys. The boys informed me that they had cliscovered a large number of birds flying out from a tree. I went myself to 
the tree, and found that the birds were swallows of the chimney kind. The tree was an elm of a large size, and hollow fifty or sixty feet from the ground. Remaining for several days in the vicinity $I$ observed the swallows in the fore part of the day going out, and in the latter part of the day going in at the same place. I chopped a hole in the treef from whence I could see through it to the place where they went out, and found that they cxtended from fifty or sixty feet in height near down to the ground; and appeared to be sticking to the tree as thick as they could be placed, and that the sides of the cavity were every where lined with them; a considerable part of them seemed to lie in a torpid state."

From these accounts I am led to believe that the house swallow, in this part of America, generally resides during the winter, in the hollow. of trees ; and that the ground swallows, find security in the mud, at the bottom of lakes, rivers, and ponds.

Of the SingING Binds, the following are the most distinguished, either by the variety of their notes, or by the melody of their sound: The Robin. Thurdus Migratorious.

Skylark. Alauda Alpestris.

Thrush. 'Turdus Rufrus.

Thrasher, or Mockbird. Turcius Polyglottos, Boblincoln. Emberiza Oryzivora.

Yellowbird. Fringilla Aurea.

Blucbird. Motacilla Cocrulï.

Wren: Motacilla Regulizis.

Red winged Blackbird. Turdus Niger Alis Sw: perne Rubentibus. 
Catbird. Muscicapa Vertice Nigro.

Golden Robin, or Goldfinch. Oriolus Aureus. Springbird. Fringilla, Hangbird. Oriolus Icterus.

'T'ne only natudal music, is that of birdse In the uncultivated state, and parts of the country, this delightful sound is not to be heard. Either disgusted with so gloomy a scene, or disliking the food in the uncultivated lands, the musical birds do not deign to dwell in such places; or to put forth their melody to the rocks, and to the trees. But no sooner has -man discharged his duty, cut down the trees, and opened the fields to the enlivening influence of the air and the sun, than the birds of harmony repair to the spot, and give it new charms by the animating accents of their music. From break of day till about nine o'clock, the lovely harmony is heard from every quarter. About that time of day, the music ceases. The musicians retire to other employments; and there is no further concert, until next morning. This is one of the most delightful scenes, which nature affords : But like most of our delicate pleasures, it is not to be enjoyed, but in the cultivated state.

A great variety of birds generally resort to the ponds, rivers, and lakes ; which on that account, are commonly distinguished by the name of Water Fowul. Among these aquatic birds, the most common are

The Goose, three species. Anser Canadensis. Duck, eight or ten. Anas

Teal, two. Anas.

Heron, two. Ardea. 
Gull, two. Larus.

Shelldrake, three. Mergins.

Crane. Ardea Canadensis.

Stork. Ardea Ciconia.

Loon. Colymbus Inmer.

Waterhen. Alea Artica.

There are many other birds, which do not fall under either of the above descriptions. Of this kind, the following are the most common and numerous.

The Eagle, two species. Falco.

Hawk, four. Falco.

Owl, three. Strix.

Woodpecker, seven or eight. Picus.

Kingbird. Lanius Tyranmus.

Crow Blackbird. Gracula Quiscula.

Cuckow. Cuculus Americanus.

Kingfisher. Alcedo Alcyon.

Woodcock. Scolopax Rustica.

Woodsnipe. Scolopax Fedoa.

Quail. Perdix Minor.

Curlew, two. Scolopax -

Plover, four. Charadrins.

Wild Turkey. Maleagris Gallopavo.

Turtle Dove. Columba Carolinensis.

Whip poor Will. Caprimulgus Europens, $\boldsymbol{B}$.

Nighthawk. Caprimulgus Americanus.

Hedgebird. Muscicapa Canadensis.

Crossbill. Loxia Curvirostra.

Hummingbird. Trochilus Colubris.

IN addition to these, there is a mamillary biped, the Bat (vespertilio mucimus :) And a great varicty and number of small birds, which have never been enumerated, described, or classed. We meet with them every day in the fields, but 
they are not distinguished by any proper names.

IT is worthy of remark that in the birds of America, nature proceeds from her most minute and curious, to the most sublime and magnificent productions. The Hummingbird is the least of all birds. The Condor, a bird of South America, in bulk, strength, and courage, is the greatest. Both of these are peculiar to America. 'The gradation from the Icast to the greatest, through all the intermediate steps and degrces, is nicely and beautifully filled up with ar. infinite variety of others.

\section{F IS I E S.}

OF the great variety of fish, which nature has produced in the vaters of America, but a small part are found in the internal parts of the continent. The largest collection of waters which we have in Vermont, are the lakes Cham. plain, Memphremagog, Connecticut river, with the ponds and streams connected with them. In these waters we hare

The Sturgeon. Acipenser Simrio. Silmon. Salmo.

Salmon trout. Salmo Salar.

Bass. Perca Occlata.

Pickerel, or Pile. Esar Lucius.

Shad. Clupea.Alosa.

Alewife. Chupea.

Eel. Murcena Anguilla.

Trout. Tracta.

Red Perch. Perca Fluriatalis.

T'hite Perch. Perca Lucioperca.

Pout. Silums Felis. 
Shiner. Perca Nobilis.

Chub. Perca Philadeiphica.

- Bream. Perca Chrysoptera.

Bret. Clupea IIInima.

Menow.

Sucker.

Dace.

Migration is not peculiar to the birds: Severail kinds of fishes, have as regular periods of approach, and departure, as the birds of passag.e. This is the case with the salmon. In the spring, about the 25th of April, these fish begin to pass up Connecticut river, and proceed to the highest branches. About the same time, or a little later, they are found in Lake Champlain, and the large streams which fall into it. Jo strong is this instinct of migration in the salmon, that in passing up the rivers, they force their passage over cataracts of several feet in height, and in opposition to the most rapid currents. They are sometimes seen to make six or seven attempts, before they can succeed to ascend the falls. Then they are thus going up in the spring, they are round and fat, of an excellent taste, and flarour. From the first week in May, to the second week in June, they are taken in great numbers. When they arrive at the upper parts of the rivers, they deposit their spawn, and remain there during the summer season; but become very lean, and faccid. Towards the latter end of September, they rc. turn to the occan; but so much crnaciated, that they are not tairen, or used for food. Some of these salmon in the spring, will weigh thirty fire or forty pounds. They migrats only to 
cold waters. None of them are ever found to the south, or west, of Connecticut river. Those that go further to the northward, and pass up the river St. Lawrence, are generally more large and rich, than those which come from the south. ward.

The Salmon Trout, in its form, dimensions, and appearance, very much resembles the salmon; but the meat is of a finer grain, and of a more delicate taste, and flavour. This trout is found in Lake Champlain, and in the rivers and ponds, which are connected with it. These fish are taken with the hook and line, like the cod and haddock. Trouts from seven to ten pounds are common. In a pond at Leicester in this state, some have been taken which weighed tweinty five pounds: Others much larger have been seen leaping olit of the water, which the fisherman supposed would weigh from thirty five to forty pounds.

THE Pike or Pickerel abounds much in Lake Champlain. It is there called by the name of Muschilongoe, and grows to a great size. They are easily taken with a spear, and some of them have weighed forty pounds, and were six feet in length.

$\mathrm{OF}_{\mathrm{F}}$ the small fish, which reside in the brooks and small streams, the most numerous and use. ful, are the trout, perch, and sucker. The trout, in its colour, form, and taste, resembles the salmon trout, but is of much smaller dimensions. The largest of them, will not weigh more than trro pounds and an laalf, or three pounds. This fish is found in all the streams, which have their origin in the mountains; and 
generally very near their sources, in the high lands. The perch and the sucker are also very numerous, and useful, and of nearly the same dimensions. The most uncommon instance, which I have ever seen, of the multiplying power of nature, was in the increase of these fish. At 'Tinmouth, is a brook about twenty or thirty feet wide, and two or thrce deep; in which the trout and sucker were to be found of the common size, and number. . A dam was built across this stream, for the purpose of supplying water for a sawmill. This dam formed a pond, which covered by estimation, about a thousand acres, where the trees were thick, and the soil had never been cultivated. In two or three ycars, the fish were multiplied to an incredible number. They were become so numerous, that at the upper end of the pond, where the brook fell into it, in the spring the fish are seen running one over another; embarrassed with their own numbers, and unable to escape from any attempt that is made to take them. They are taken by the hands, at pleasure; and the swine catch them without dificulty. With a net, the fishermen often take a bushel at a draught, and repeat their labour with the same success. Carts are loaded with them, in as short a time, as the people could gather them up, when thrown upon the banks; and it is customary to seil them in the fishing season, for a shilling by the bushel. While they have thus increased in numbers, they are become more than clouble to their former size. This extreme increase does not seem to be derived from any other cause, than that of collecting the waters VOL。I。 
in such a quantity, as to form the pond; andi thus increase the mcans of subsistence, by carrying the water over a large tract of rich, and uncultivated land. Events of a similar nature generally take place, when an artificial pond is made in any part of the country, not before cul. tivated ; and probably from the same cause.*

In the production of fish, nature seems to have been extremely prolific, in every part of America. Their species, their multipiying power, and the age at which they become pros lific, are beyond our knowledge, and computation. The broolis, rivers, ponds, and lakes, are cvery where, stored with them. The sea coasts are one continucd range of fishing banks, covered with cod, haddock, and other animals of the ocean. The whale is gencrally esteemed the greatest animal, which nature has produced in the water : In the seas of America, this is to be found in its greatest perfection of magnitude and numbers.

Fossix shells are frequently found at some distance from the banks of our lakes, rivers, brooks, and meadors. Some have been found on the sides, or rather in the gullies of the mountains. Such productions require a collec. tion of water for their formation. Naturalists have proposed many theories and speculations,

* THE number of fish in the rivers of South America, is fuily equal to any thing that takes place, in the northern parts of the continent. "In the Maragnon," says P. Acugna, "Fish are so plentiful, that, without any art, they may take them with thcir hands."

"IN the Orinoco," says P. Gumilla, "besides an infinite variety of other fish, tortoises or turtle abound in such numbers, that 1 cannot find words to express it. 1 doubt not but that such as read my account will accuse me of cxaggeration: But I can affirm, that it is as dificult to count them, as to count the sands on the banls of that river." Hist. del. Orenoque, ii. c. $22, p \cdot 59$. M. de la Condamine confirms their accounto 


\section{HISTORY OF VERMONT. 151}

to account for the collection of water in such places, where there are now no appcarances of the kind.

IN their descent from the mountains, the brooks and rivers must every where have formed themselves into lakes, ponds, and small collections of water: And it was not until after long periods of time, that they could form for themselves channels of such depth, as to dis. charge the waters which had been thus collected. Some of these ponds nere formed on the sides of the mountains, and others overflowed what are now called the meadows; and many of their ancient phenomena yet remain. 'The waters have long since formed the channels, by which they are now discharged into the ocean. In such places, fossil shells are yet found: they are the productions of former times, when those places were covered by the waters descending from the mountains; then collected into quantities for want of natural channels, now drawn off by the depth of the channels which the waters have formed, and constantly render: ed more and more deep.

\section{REPTILES AND INSECTS.}

THA'T class of animals, which are distinguished by the names of reptiles, and insects, are numerous in every part of America. They abound the most, and are of the largest size, in the hottest parts of the continent. In a climate so cold as that of Vermont, they are comparatively of but a few species, and small in their size; but they exist in rreat numbers. The following are our 


\section{AMPHIBIOUS REPTILES。}

The Turte, two species. Testudo.

Toad. Rana.

Frog, five. Rana.

Lizard. Lacerta punctata-

Swift. Lacerta fusciata.

THERE are several accounis in natural history, of toads being found in the hearts of trees, and in solid recis, wholly inclosed, and shut up from the air, and all appearuace of food; and being taken alive, out of such situations. In the Memoirs of the Academy of Sriences, there. is an account that in the year 1731, a toad was found in the heart of an old oak near Nante, without any visible entrance to its habitation. From the size of the tree, it was concluded, that the toad must have been confined in that situation, at leasi eighty or an liundred years.* We have several instances in Vermont, cqually, extraordinary. At Windsor, a town joining to Connecticut river, in Septenber, 1790 , a living frog was diug up at the depth of nine feet, from the surface of the earth. Stephen Jacobs, Esq. from whom I have this account, informs me, that the place where this frog was found, was about half a mile from the river, on the intervale lands, which are amnually orerflowed by its waters. At Castleton, in the year 1779 , the inhabitants were engaged in building a fort, near the centre of the town. Digging into the earth five or six feet below the surface, they found many frogs, apparently inactive, and supposed to be dead. Eeing ex-

- Smellie's Philosophy of Natural History, p. I22. 
posed to the air, animation soon appeared, and they were found to be alive, and healthy. I have this account from General Clarke, and a Mr. Moulton, who were present when these frogs were dug up. Upon viewing the spot, it did not appear to me, that it had ever been orcrfowed with watcr, but it abounded with springs. A more remarkable instance was at Burlington, upon Onion river. In the year 1788, Samuel Lane, Esq. was digging a well near his house. At the depth of twenty five or thirty feet, from the stiiface of the earth, the liabourers threw out with their shorels, something which they suspected to be groundnuts, or stones covered with earth. Upon cxamining these appentunces, they were found to be frogs; to which, the earth crery where adhered. The examination was then made of the earth, in the well, whore they rore digging. A large number of frogs were found covered with the earth, and so numerous, that several of them were eut in pieces by the spades of the workmen. Being exposed to the air, they soon became active; but unable to endure the direct rays of the sun, the most of them perished. This account is rom Mr. Lane, and Mr. Lawrence, one of the rorkmen, who were both present when the frogs were dug up. From the depth of earth, with which these trogs were covered, it camnot be doubted but that they must have been covered over in the earth, for many ages, or rather centuries. The timber on the adjacent land had grown very large; a pine tree not far from the well, was more than twelve feet in circumference. The appearances denote that 
the place from whence these frogs were taken, was once the bottom of a channel or lake, formed by the waters of Onion river. In digging the same well, at the depth of forty one feet and an half from the surface, the workmen found the body of a tree eighteen or twenty inches in diameter; partly rotten, but the biggest part sound. The probability is, that both the tree, and the frogs were once at the bottom of the chamel of a river, or lake ; that the waters of Onion river, constantly bringing down large quantities of earth, gradually raised the botton : that by the constant increase of earth and water, the water was forced over its bounds, and formed for itself a new channel or passage, in its descent into Lake Champlain. How vigorous and permanent must the principle of life be, in this animal! Frogs placed in a situation, in which they are perpetually supplied with moisture, and all waste and perspiration from the body prevented, preserve the powers of life from age to age ! Centuries may have passed since they began to live, in such a situation; and had that situation continued, nothing appears, but that they would have lived for many centuries yet to come! 单

\section{SERPEN'TS.}

The Rattle Snake. Crotalus horrictus. Black Snake. Coluber constrictor.

Green Snake. Coluber saurita. Striped Snake.' Anguis cryx. Water Adder. Coluber fasciatus,

* Appendir Nóo. 11. 
THESE are all the species of this kind of anumals, of which I have any account; and these are but seldom to be met with in $\mathrm{Ver}$. mont.

THER is a curious phenomenon respecting two of these species, which seems to deserve further inquiries. The farmers, and other persons who frequently meet with the rattle snake; and with the black snake, seem universally to believe that each of these animals; have a power of fascination ; or as it is commonly expressed, of charming birds, and other small animals. The account which is generally given, is this : the snake lies stretched out his full length, in some open place; his head raised eight or ten inches from the ground; his colours glow with their greatest brightness; his eyes play with an uncommon brilliancy, and fire; and are steadily fixed on the enchanted animal. During this scene, the bird appears to be in the greatest distress; is constantly putting forth the most mournful accents; at the same time, is performing a number of irregular circular motions: and at the end of each, approaches nearer to the snake: this scene continues, and is incessantly repeated, until the bird, without any power to escape, comes within the reach of the voracious jaws of the serpent, when it is instantly seized: But if the snake is attacked, or so disturbed during the operation, that his attention is turned another way, the charm is broken; and the bird recovering his liberty, immediately flies off. I have never myself seen any thing like this fascinating scene; but I have had accounts exact. ly similar from more than a dozen persons, 
whose intersity I cannot in the smallest degree call in question. 'There is room, however, for mistakes in such kind of observations; and in most of them, the snake was disturber, before the scene was finished. That there is something curious in these appearances, cannot be doubted. But whether these snakes have such powers, or by what causes such erents are produced, seens to require more accurate observations, and a more philosophical investigation.*

\section{INSECTS.}

THE insects are too minute, and numerous, to be particularly described. The most conmon are the bectle, grasshopper, cricket, butterfly, firefy, blackfly, moth, flea, ant, musqueto, spider, hornet, wasp, bumble bee, honey bee, various kinds of bugs, and several species of worms. Of these the musqueto is the most troublesome. The weavil, the Hessian fly, and the locust, are not known in this part of the continent.

Of the bee, therc is a species which is gen. erally called rith us, the bumble bee. This is indigenous to the country, and much larger than the common bee. It forms a nest upon the ground ; and produces a species of honey, in transparency, beauty, and sweetness, fully equal to that of the lioney bee; but much less in quantity. Whethe: the honey bee is a native of the country, seems to be viewed by some as uncertain. I do not find much reason to doubt, but that it was in America, before the Europe.

4 Appezdix No. IV. 


\section{HISTORY OF VERMONT. $15 \%$}

ans made their first settlements in the country. From the pictures and tribute rolls of the Mexicans, it appears that the honey bee was known, and that honey was one part of the annual tribute which was paid to their emperors before the arrival of the Spaniards. Clavigero, in his history of Mexico, confirms these accounts ; and mentions six kinds of bees which make honey; two of which have stings, and one in all respects agrees with the honey bee of Europe. A species of the honey bee, but without stings, was found in Chiapa, and Yucatan. The same according to Margrave, was found in Brasil. In 1540, among the provisions of the natives of Florida, "a pot full of honie of bees," was found by Soto. From these accounts, it is not to be doubted, but that the honey bee was indigenous, and had spread over the empire of Mexico. To the east, it had advanced as far as Florida ; And to the south, to Yucatan, nd the country of Brasil. To an immense' ntry, then, the honey bee $r$ 'idigenous, : :ommon. There was no cause 1 the nature, he animal, or of the climate, to ? vent their spreading to the northward. They live in the hollow trees in the woods of Veri nt, from year to year ; and are always found of their full dimensions, vigorous, and plentifully supplied with honey ; and they bear the cold of our winters, much better in the hollow of a large tree, than in any of our artificial bee hives. They live and abound in Russia, where the climate is much more severe, than it is in this part of America: They would therefore naturally extend, and spread along the country, where they could find the means of

VOL. I. 
subsistence, and a climate not unsuited to theit support. It has always been found far beyond the English settlements. From our earliest acquaintance with Lake Champlain, it was to be found in the open lands, along those shores, at the distance of an hundred miles from the English or French settlements; and long befure those settlements had begun to atterd to the cultivation of this animal: And from the first settlement of New England, hunting for their nests has been a favourite and profitable amusement. But as the chicf food of the bee is from the blossoms and flowers of plants, it does not multiply so fast in the uncultivated parts of the country, as where the improvements of agriculture and gardening, are constantly producing a greater variety, and number of vegetables.

To the tribes of reptiles and insects, we have affixed the idea of something, unpleasant, diminutive; or odious. The designs, the wisdom, and the power of the Creator, are not to be estimated by such feelings, fears, and prejudices. The reptile, the insect, the fish, the bird, and the quadruped, one as much as the other, denote wisdom, power, and design, in the author of nature: And they are alike evidences, and instances, of the power of animated nature, in the different parts of the earth. We may therefore as justly and clearly decluce the energy and force of animated nature in any country, from the number and magnitude of the insects, as from the species and dimensions of any other animals. The European philosophers have dwelt with wonder and astonishment, on the numbers and size of these animals in America. 
The facts are justly stated, in several of their accounts; and they ought to have concluded from them, that the soil was uncommonly rich, fertile, and luxuriant. Anxious to find marks of degradation in America, they have almost universally advanced a contrary conclusion : that this prolific power of nature, denoted an uncommon corruption, and degradation of climate. No conclusion was cver further from the truth, or more remote from probability. It is only a rich soil, and a temperate climate, which can produce what they call a rank vegetation, or numerous reptiles and insects, of the largest size.

Fom this imperfect view of our quadrupeds, birds, fishes, and insects, instead of finding nature but weak and feeble in America, as M. de Buffon has supposed; $*$ her animals appear to be marked with an energy, and a magnitude, superior to what is found in Europe; and equalled only, by the magnificent and vigorous productions of Asia.

* "La nature vivante est heaucoup moins agissante beaucoug moins forte." Hist. Nat. xviii. I22. cdit, Paris, 1764 . 


\section{CHAPTER VII.}

Original Inhabitants. The Employments, Civil Government, System of War, Education, Manners, and Customs of the Indians; the Advantages, and Disadvantages of the Savage State.

IN the formation of the mountains, rivers, vegetables, and animals, the poirers of nature appear to rise in a steady and beautiful progress. This progress seems to be completed in the production of a rational, moral, and accountable animal. This animal is MAN : And he evidently appears in every part of the globe, to be at the head of all the productions of nature : But the mein of different colintries and nations, appear to be very different from one another.

THE original inhabitants of this country were the Indians: These were the only species or sind of men, that had spread over America. It will be more difficult to give a just account of the man of America, than to describe its vegetables, and animals. The latter are subject to stated, and invariable laws; they pass through but few changes and variations, and are always to be found in that state, in which nature placed them. Man is subject to a great variety of al. teration, and improvement. In his rudest and most simple state, he appears but little superior to the brute; in his highest improvement and polish of manners, he appears at an infinite re. move from the bare animal; and in all the 
stages of his progress from the one state to the other, he passes through an endless variety of situations and circumstances, which are constantly giving a new appearance to his capacity, powers, passions, manners, and pursuits. The natural history of man is therefore the most difficult, but it is also the most useful and important subject we can contemplate. In examining the history of the Indian of America, we shall find man in the most simple, rude, and unimproved state, in which he has ever been placed, or viewed.*

Appearance and Countenanace. The appearance of the Indians was different from any, under which man had ever been viewed before. 'The colour of their skin is of a reddish brown, nearly resembling the colour of copper, but rather darker. Their faces are broad, the nose appears flattish, their eyes black, small, and very active. The hair of their heads is always black, coarse, long, and perfectly straight ; and they generally appear without any beard. The men are taller than the Europeans, but rarely corpulent; and their bodies appear to be firm, strong, and well proportioned. Their features are regular and well adjusted, but their countenance discovers something wild, fierce, and sullen. None of them are seen crooked, mutilated, or deformed; defective in any of their senses, or deficient in any of their bodily organs ; but straight, well built, and robust. In the ap-

* THE following account relates chiefly to the Indians in the northérn parts of America. I have received much assistance from the wri tings of Dr. Robertson, and other authors. But the authonities on which the accounts are founded, are chiefly the relations of those persons who have lived among tbe Indians, and been intiniately acquainted with thern. 
pearance, aspect, and countenance of the Indians, there is an uncommon uniformity, and resemblance. It is the same in all climates, and in all the tribes of America. It does not vary with heat, cold, situation, employment, or other circumstances; but the Indian countenance has the same combination of features, and peculiarity of aspect, in every part of America.

Girployinent, and Method of Procuring Subistence. The food proper for man, is to be found in every part of the earth. But the means and the method of procuring it, are different among different nations, and in different stages of society. The savages of North America had discovered the properties and effects of those seeds, berries, and roots, which the earth spontaneously produces; and one part of their food was derived from this source. Fishing was another method which they used to procure subsistence. The great plenty and variety of fish, with which the rivers of Ameriea abounded, rendered this kind of provision asy to be procured, and of great use. The Indian had acquired much skill and address, in his method of catching the fish; and he was accustomed to dry, and smoke them, in order to preserve them. The falls of rivers were the places, to which they most resorted for this purpose : And most of these falls were the places, where some of their tribes or small companies resided: And they were generally distinguished by some particular Indian name. A more general and effectual method of supports was hunting. "The fruits which the earth spontaneously produced, were but few, and of short 
continuance. A few tribes only could be accommodated, by the vicinity and convenience of a river: But game was every where to be found. The bear, the deer, the beaver, the fox, and other animals, were in great numbers, and in cvery part of the northern continent. From these, the Indian derived his most sure, and plentiful support. But this method of procuring food, required great efforts of invention, and activity. The strength, the fierceness, and the swiftness of the wild animals, the feebleness of the weapons, the bow, arrow; and club, with which the savage attacked them, joined to make the business of the hunter laborious and dificult ; and called forth all the active powers of the-savage. And here, he appeared to the greatest advantage; fertile in invention, sagacious in distinguishing and observing; nice and accurate in tracing the animal; inderatigable, and persevering in the pursuit. An employment which thus gave exertion to all the invention, courage, force, and vigor of the man, naturally became the most honourable employment: And the most dexterous hunter became the most distinguished savage of the tribe. To these methods of procuring food, were added some feeble attempts in agriculture. Indian corn, beans, pompions, and squashes, were the only plants they cultivated. The culture of these was wholly in the hands of the women. Without the use and knowledge of any of the domestic animals, altogether destitute of the proper instruments of husbandry, their efforts were weak and languid; and the supplies they derived this way, were but small. 
THESE were all the methods of procuring food, with which the Indians were acquainted. They afforded them but a scanty and precarious support. When the game was plenty, and the hunter successful, they had an abundance of food. When the season of the year was unfavourable, and their success but small, they were reduced to scarcity and want. Their sufferings this way, were sometimes extremely severe. And there was no year, in which they were not subject to these extremes, of great plenty, and severe famine.

THE appetite of the Indian conformed to this state of things. In the seasons of plenty, the savage indulged himself to great excess : In the time of famine, the Indian bore his hunger with astonishing patience, and firmness. So accus. tomed was he to this irregular method of living, that excess and famine were cqually familiar to him ; and his constitution and health remained firm and vigorous, under the extremes of both.

From this situation and employment of the Indian, all the remilations, customs, advantages, and disadvantages of the savage state, were derived.

Societr. When any considerabie number of the human race subsist near each other, they will always combine in some form of society. Mutual wants, dangers, dependencics, interests, and benefits, operating with the appetite man has for society, will not fail to produce this effect. The situation and employment of the Indians, determined what the nature and extent of this society must be, among them. The chief source of subsistence among them, was 
Junting. On this account, a large territcry became necessary for the support of a small num. ber of people. Like the game on which they subsist, they must bc dispersed over a large tract of country, or they cannot procure food. In this stage of society, the extent of it is derived from its situation. Its territory must be large, the number of people will be small, and all hostile tribes must be kept at such a distance, as not to encroach upon the territory or the game. This was the state, in which the savages were found. Divided into a number of tribes, small in the number of people, large in the extent of territory, and generally unfriendly and hostile to each other.

Nature of tileir Civil Governaent. From this state of society, arose a species and form of government peculiar to the Indians. The design and object of government among the savages, was not the property, security, or conduct of the individual; but the property and safety of the tribe. The idea of property is suggested by nature ; and was clear, distinct, and just, in the mind of the rudest India. The fish in the river, and the game in the forest, were not the product of his care or labour; and he had no idea that they belonged to him, more than to any other individual. But when they were acquired by his personal exertion, no other savage doubted but that they were become his particular and exclusive property. The river, or the forest, from which they were taken, were not personal but public property : they belonged to the tribe. No individual claimed a right to them, in preference to, or yol. $\mathrm{I}$. 
cxclusive of others. These were the properi of the tribe, belonging equally to ails, and io which all had a right to repair in quest of subsistence, and hadan equal and common privis gro When the Indian bui!ded his house, or plinned his corn, no one had a right to molesit him; the house and the corn became his. Whes he relinquished his possession, any other of the tribe had a right to take possession, and pursue the same employment that he had done. The fruits of their orn labour and inclustry, ras al. ways the property of the individual: The river, the forest, the hunting ground, the land or the territory, was the property of the tribe. 'The former was of so simple a nature, so well anderstood, and so universally agreed to, that few controversies could ever arise about it; common custom and consent was sufficient to adjust and regulate every thing of this nature. The latter contained all the property, the means of subsistence, and that on which the whole tribe depended for their existence. This was the great object and aim of their government; to protect and defenet that, on which the whole tribe subsisted. In such a state of society, the injuries that would be done to individuals rould not be many in their number, or of ten of such a kind, as to endanger the cxistence or sovereignty of the tribe. The right of redressing them, was therefore left in private hands. This has always been the case, in the infancy of society and government. If injuries were done, if blood was shed, it belonged to the friends and family of the injured person to seek redress. If the chiefs interposed, it was only by way of 


\section{HISTORY OF VERMONT. 167}

eounsel and advice. The friends of the injured person might accept of their advice, or of the reparation ofiered by the aggressor, or they might reject it : If it was accepted, all was settlesi in a quiet and friendly manner : If rejected, nothing remained but to pursue the aggressor with a revenge and rage, that aimed at nothing Jess than lestruction and death.

'Tin form and manner of the Indian government, was the most simple that can be contrived, or inagined. There was no king, nobility. loris, or house of representatives, among them. The whole tribe assembled together in their pub ic councils. Destitute of writings, records, ard history, to preserve the memory of their public transactions ; their most aged men becarne the depositories, of what had been gathered from experience, observation, and a knowledge of their former transactions. It is by them that the debates and consultations are chiefly carried on. Their councils are slow, solemn, and de. liberate. Every circumstance that they can foresee, is taken into consideration. The probable advantages and disadvantages of every measure, are examined and weighed. All the prospects of success and disappointment, are revolved in their debates; and nothing is omit. ted, which occurs to their views or expectations. The whole business is a scene of consultation, and advice. And the advice has no other force or authority, than what is derived from its supposed wisdom, fitress, and propriety.

' $\Gamma_{\mathrm{H}} \mathrm{E}$ strength and pozver of the govermment, is placed wholly in the public sentiment. The chief has no authority to enforce his counsels. 


\section{¿58 NATURAL AND CIVIL}

or compel to his measures. He is fed and clothed like the rest of the tribe. His house and furniture are the same as those of others. There is no appearance, or mark of distinction: No ccremony, or form of incluction into office : No ensigns or tokens of superiority, or power. In every external circumstance, the chicfs are upon a level with the rest of the trive: And that only which gires weight and authority to their advice, is the public opinion of their superior wistom and experience. "Their laws stand on the same foundation. There was no written law, record, or rule of conduct. No public p.ocedient, established courts, forms or modes of procecding. "The causes and occasions of contention were so fcri, that they did not much afiect the tribe. And when the chiefs interposed in the concerns of individuals, it ras not to compel, but only to counsel and adrise them. The public opinion pointed out what was right, fit, and proper to be cstcemed laws and rules of conduct. "These rules or latrs derived from nature, were seldom wrong, obscure, or inconsistent; but generaliy plain, clear, and useful. Their penalies and punishments riere derived from the same source. Loss of char. acter, and reputation, disgrace, exclusion from the tribe, and death, were the punishments to which offenders were exposed, according to the nature und aggravation of their crimes. These punishments were not described, and assigned to a particular crime by a written law: but they rested upon the public opinion of the tribe, and derived great force and power from it. An offender who had been greatly and deeply guilty, 


\section{HISTGRY OF VERMONT.}

Sfed from the tribe, as the only way to safety, peace, and rest.

"IIERE was a fitness and propriety in this govermment, or rather, it was fully adequate to its end and design, and to the situation and state of the savage. A modern statesman would smile at this idea of Indian government : And because he could find no written constitutior, or bill of rights, no mutual checks, and balances, accountability and responsibility, pronounce it weak, foolish, and contemptible. But it was evidently derived from tile dictates of nature, and well adapted to the state and situation of the savage. The idea of property was so plain and clear, and the objects to which it related were so few and simple, that there was no necd of a code of laws to describe and define it. The rights of the individual, his freedom and liberty, were so strongly felt, and so universally acknowledged, that no person dared to invade then. The crimes of the vicious received a just and a full punishment, in the disgrace, contempt, and danger, they brought upon the guilty. The individual had all the security, in the public sentiment, custom; and habit, that government can any where afford him. All that was to be defended was the territory; the interest, the independence, and sovereignty of the tribe; and every part of the government was adapted and designed to form, to animate, and to inflame, a national spirit of vigour and independence.

AGREEABLY to its nature and design, the tendency and effect of the savage government, was equality, freedom, and independence, among 
all the members of the tribe. In respect to rights and privileges, the savage knew no supesior. Of abasement, humiliation, dependence, on servitude, he had no idca. Depending on Lis own exertions for food and raiment, he had never looked to another for assistance, promofion, or wealth. When the interest of the tribe wis in question, or in danger, the wisdom and experience of years was consulted, to advise and determine: And their counsels became matters of great respect. But constraint, compulsion, and force, was the object of the highest detestasion and horror. Every measure of the government tended to confirm and increase the spirit of freedom, cquality, and independence, and to render it strong, fierce, and permancnt, through the whole tribe.

Strstem of Mar a Mong the Indans. The civil regulations of the savages were all designed to qualify and prepare them for war. Among the causes that lead to this, an opposition of interests, was the most common and powerful. No people ever had more clear, or more just ideas of their own rights and property, than the Indians. They not only understool their orn personal rights, but they were perfectly well acquainted with the rights and property, that were vested in the tribe. Each tribe claincd the soil in their own domains. This right was viewed as complete, perfect, and exclusive: Such as entitled them to the full and entire possession ; and to oppose by forcc and violence, all encroachments upon the soil, or game, in any part of their territories. The founds of these territories were extensive, and 
inl defined. Real or supposed encroachments and injuries, were constantly taking place. Hence arose innumerabie subjects of dispute and controversy, which easily inflamed the fierceness of the savage temper, and brought on mutual injuries, reproaches, hostilities, and war. In this state, most of the Indian tribes were found. Interest had become a source of discord, among the neighbouring tribes. From this cause, arose most of their inveterate and perpetual rars.

'THE manner in which the Indians carry on thcir vars, is very different from that of civili. zed nations. To defend themselves against an enemy, they have no other fortifcation but an irregular kind of fortress, which they call a castle or fort. It consisted of a square without, bastions, surrounded with pallasadoes. This was erected where the most considerable number of the tribe resided, and was designed as an asylum for their old men, their women, and children, while the rest of the tribe were gone out to war. The weapons of the Indian wcre a club made of hurd wood, a bow and arrow. Thus armed, the Indian takes with him a small bag of corn, and is completely equipped for a campaign. When he takes the field, it is with such a number of warriors as the tribe can supply. During their march, they are dispersed in straggling companies, that they may better supply themselves by hunting. When they approach near to the enemies' frontiers; their troops are more collected: All is then caution, stratagem, secrecy, and ambuscade. Thcir employment as hunters has taught them great 
address and vigilance, in following and surpri. sing the game. Their mode of war is the sarue, as that of hunting. With great ingenuity, they will find and follow the track of their enemies: With a surprising patience and per. severance, they will wait for the moment, when they find him the least able to defend himself. and when they can find an enemy unprepared, they make their attack with great fury, and with pretty sure success. In their battles they always endearour to secure themselves behind the trees or rocks, and never meet their cnemy in the open ficld, or upon equal terms, if they can avoid it. The metliod of the Europeans, of deciding a battle in the open field, they re. gard as extreme folly and want of prudence. Their established maxims are to obtain a superiority in situation, numbers, concealment, or some other circumstance before the battle: In this way, to preserve the lives of their own par. ty, and destroy their enemies, with as litile loss as possible to themselves. A victory obtained with the loss of many of their own party, is a matter of grief and disgrace, rather than of exultation : And it is no honour to fall in the field of battle, but riewed rather as an evidence of want of wisdom, discernment, and circumspection. When the attack is to be made, nothing can exceed the courage and impetuosity of the savage. The onset begins with a general outcry, terminating in a universal yell. Of all the sounds that discord has produced, the Indian warwhoop is the most awful and horrid. It is designed and adapted to increase the ardor of those who make the attack, and to carry terror 
and horror into the feelings of those, on whom the attack is made. "The Indians immediately come forward, and begin the scene of outrage and death. All is then a scene of fury, impetu. osity, and vengeance. So great is the rage of the savage, that he has no regard to discipline, subordination, and order. Revenge, takes an entire possession of his soul : Forgetful of all order, regardless of discipline and danger, he aims only to butcher and destroy. If the Indians remain masters of the field, they always strip and scalp the dead. Leaving the bodies of their enemies, naked, unburied, and often man. gled, they carry off the plunder and scalps; and make a very swift and sudden retreat. Upon their approach to their own tribe, a herald is sent forward to announce the event : the tribe is collected, and the conquerors make their entry with their ensigns of triumph : the scalps stretched upon a bow, and elevated upon a pole, are carried before them, as the tokens of their valour and success, and monuments of the ven. geance they have inflicted upon the enemies of their country.

TH E prisoners which they have taken, make an important part of their triumph. The savages are anxious to take as many of these as possible. During their march, they are generally treated with a degree of humanity and kindness; but the greatest care is taken to prevent their escape. When they arrive at the place of their destination, the old men, women, and children of the Indian tribe, form themselves into two lines, through which the prisoners must run the gantlet to the village. If the prisoner is young, voL. ?. X 
active, and a good runner, he makes his way through the lines without receiving much inju. $5 y$. It he is weak, old, and infirm, he receives much damage by the blows, stripes, and bruises, he receives. When this scene is finished, the prisoners are conducted to the village, treated with apparent good humour, and fed as well as the Indians' fare admits.

To the villuge thus assembled, the head warrior of the party relates every particular of the expedition. When he mentions their losses, a bitter grief and sorrow appears in the whole as sembly. When he pronounces the names of the dead, their wives, relations, and friends, put forth the most bitter shrieks, and cries. But no one asks any question, or interrupts the speaker with any inquiry. The last ceremony is to proclaim the victory. Every individual forgets his own loss and misfortune, and joins in the triumph of his nation. Their tears cease, and with one of the most unaccountable transitions in human nature, they pass at once from the bitterness of sorrow to all the extravagance of joy. The whole concludes with a savage feast, songs, and dance.

THE fate of the prisoners is next to be decided. The elders and chicfs assemble and de. liberate concerning their destiny. The women and children are disposed of, according to the pleasure of their captors; but they are seldom or never put to torture, or death. Of the men some are appointed to supply the places of such Indians as have fallen in battle. These are delivered to their friends and relations, and if they are received by them, they have no suf- 


\section{HISTORY OF VERMONT.}

ferings to fear : they are adopted into the fami. $l y$, and succeed to all the privileges of the deceased; and are esteemed as friends, brothers, and near relations. But if they are not received and admittcd into the family, or if they are destined to be put to death, a most distressing and horrid scene ensues.

A stake is fixed firmly in the ground. At the distance of eight or ten fcet, dry wood, leuves, and faggots, are placed in a circle round the stake: And the whole village is collected, to bear their part in the tragedy, which is to cnsue. The prisoner is led to the stake, and tied to it by his hands, in such a manner that he inay move freely round it. Fire is set to the wood, that as it runs round the circle, the unhappy victim may be forced to run the same way. As the sufferings of the prisoner begin to become severe, the acclamations of the spec. tators begin. The men, women, and children, strive to exceed each other, in finding out new and keener methods of torment. Sorne apply red hot irons, others stab and cut with their knives, others mangle and tear off the flesh, others again bite off the nails and joints, or twist and tear the sinews. Every species and degree of cruelty, that savage rancour and revenge can invent and apply, is tried upon the wretched sufferer. But great care is taken that the vital parts may not be so injured, as to bring the torments of the victim to a speedy end. In this horrid situation, the sufferer is undaunted and intrepid. He reviles and insults his tormentors. He accuses them of cowarcice, meanness, and want of spirit ; as ignorant, unskitful, and des. 
titute of ingenuity and invention in the art of tormenting. Not a groan, a sigh, a tear, or a sorrowful look, is suffered to escape him. 'To insult his tormentors, to display undaunted and unalterable fortitude in this dreadful situation is the most noble of all the triumphs of the warrior. With an unaltered countenance, and with the decisive tone of dignity and superior importance, the hero proceeds with great calm. ness to sing the song of his death-" Intrepid and brave, I feel no pain, and I fear no torture. I have slain, I have conquered, $l$ have burnt mine enemies; and my countrymen will avenge my blood. Ye are a nation of dogs, of cowards, and women. Ye know not how to conquer, to suffer, or to torturc. Prolong and increase my torments, that ye may learn from my example how to suffer and behave like men!" With such unconquerable magnanimity and fortitude, the sufferer perseveres under every method of torment and torture. Wearied with cruelty, and tired with tormenting a man whose fortitude they cannot move, one of the chiefs in a rage concludes the scene, by knocking the prisoner on the head, or stabbing him to the heart.

THESE scenes however were not common. They seem to have been kind of honours, reserved for the warriors; and were the trials of their courage and fortitude. And nothing was esteemed more base and ignominious, than to shrink from them, or to shew any sense of fear or pain under then.

WIIEN the prisoners were adopted into the tribe of the conquerors, nothing could exceed 
the kindness and affection, with which they were treated. All distinction of tribes was forgotten ; they held the same rank as the deceased person, whose place they filled; and were treated with al! the tenderness due to the husband, the brother, the child, or friend. And it was generally the case, that the savages avoided abuse and cruelty to the women and children, that fell into their hands.

THE Indian method of carrying on a war, was so contrary to the maxims and customs of all civilized nations, that sone of the European writers, judging from their own customs, have concluded it was founded on cowardice, and arose from an ignoble and timid spirit, afraid to meet its opposers on equal ground, and depending wholly on craft, and not at all on courage and firmness of mind. No conclusion was ev. er further "from the truth. When placed in a critical and dangerous situation, no people ever discovered more valour, firmness, and intrepidity. When subdued, an Indian was never known to ask for his life. When compelled to suffer, the Indian bore it with a steadiness, a fortitude, and a magnanimity, unknown to all other nations; and of which, there are no examples in the history of war. His method of war did not arise from a sense and fear of danger ; he vas well acquainted, and always in the midst of this ; but it arose from his situation and employment, and was perfectly well adapted to it. From his situation and employment as an hunter, he acquired the art of ambuscade and surprise; and the method with which he could best succeed in taking his game, he found to be 
the most successful to ensnare and overcome his encmy. The situation and state of the country, overspread with thick forests, lead to the same method. The situation of the tribe, scattered and dispersed in the woods, suggested the same idea. "The method of fighting could not be in the open fields, but among the trees. And he wisely placed the point of honour, in the public good; where the prospeet and the probability of his success lay. Had the honour of the Indian warrior been placed, in courting fame and victory in the open field, the whole tribe would have been destroyed by the effusion of blood that must have succeeded. His max. ims therefore were bettcr' "en, and they were such as every circumsiance in his situation and employment naturally led him to: Not in an useless ostentation of daring courage and boldness, but in the public utility and advantage. So far as an enterprize depended on secrecy, subtlety, surprize, and impetuosity, the Indian method of war seems to have been fully equal to the European. The Spaniards, the French, the English, and the States of America, have had many and painful proofs of their address and prowess in this method. But when a fort was erected, or a small fortification to be carried, the Indian method of war wholly failed. Neither their arms, their arts, of their customs, were of any avail here. Wholly unacquainted with the art of fortification, they could neither erect, or take a fort of ainy strength. When the Europeans had once got possession of any part of their country, and erected a small fortification in their territories, they held it by a 
sure possession. The savages were wholly unable to dispossess them by their method of war, and nothing was left for them but to retreat further into the forests. In this way the Eng. lish, and French were making constant advan. ces into their country ; and their art of war afforded them no sufficient means, either to prevent or to redress it. But when the Europeans followed them into the woods, where their strength and art might be employed to advantage, the Indians generally surprised and defeated their armies, with great havoc and slaughter.

Education. The subsistence and safety of the tribe depended so much upon the hunter, and warrior, that these became of course the most necessary, useful, and honourable professions. When in pursuit of food, the young men put themselves under the direction of the most noted and successful hunter. Going forth to war, they followed the most renomed and successful warrior. Eminence in these profes. sions was the surest way to subsistence, to distinction, to honour, and renown. This was the basis, and formed the whole business of education, among the savages. To train up the youth to address and dexterity in hunting; to make him patient, firm, persevering, in hardship and suffering ; inveterate, fierce, and intrepid in destroying his enemies; was the chief aim and design of the parent. Every thing that had no comnexion with this, was neglected and despised. The arts of acquiring knowledge, gorerning the passions, refining the manners, and cultivating improvements, were unknown and undesired by the savage. He never corrected 
or restrained his child, taught him to moderate his appetites and passions, to submit to parent. al, or any other authority : On the contrary he was trained up to take care of himself, to gratify every inclination and appetite, and to look for food and honour in his own exertions, inde. pendence, and superiority. The parent wished and aimed to form his son to hardship and dan. ger, to bear fatigue, famine, and torture, to ensnare and take the game, and to carry destruc. tion and vengeance upon his enemies. To this plan of education, the whole aim and conduct, the instruction, the manners, and the example of the parent, was directed : the only aim and design, was to make the youth an able and accomplished hunter, and warrior. Neither the views of the parent, or the wishes and aims of the child, ever rose any higher, or extended any further than this.

NEXT to the civil and military regulations, the CUS Toms andMANNERs of the Indians clain our attention. The customs and manners of a nation, always constitute a distinguishing part of the national character; and as they vary with the progress of society, they serve to. ascertain, and mark the different stages of it. 'In several respects, the manners and customs of the Indians were different from those of other people, and are marked with a singularity peculiar to the savage state.

Gravity of Appearance. A gravity of appearance and countenance alwajs engages our attention, when we are in the company of the Indians. Placed in a situation of constant difficulty and danger, de nding altogether upon 


\section{HISTORY OF VERMONT. I81}

himself, and having ever before him pursuits; which to him are of the highest importance, the savage becomes extremely grave and serious. Every thing in his appearance and behaviour, is marked with this gravity of aspect. His behaviour to those around him, is decent and modest. His words are few and significant, and generally upon some matter of business ; scarcely ever for merriment or diversion. So great is their habit of gravity, seriousness, and silence, that it rather bears the appearance of melancholy and sadness.

Treatment of Women. A promíscuous intercourse between the sexes, scarcely ever took place among the' human race. The relation of husband and wife, has been every where understood, adopted, and acknowledged; and this was universally the case among all the tribes of the American Indians. Where the difficulty of procuring subsistence was not easily to be removed, the man had generally but one wife. Where the means of subsistence were in great plenty, and easily to be attained, the savage had often a plurality of wives. But in general, the Indian family consisted of one man and woman, and their children. This un. ion generally subsisted during the lives of the parties; but if it became a matter of choice to separate, the marriage union was dissolved, ard no calise or ceremony was necessary, but choice and consent. It is not until the refinements of society have taken place, that women acquire the rank, consequence, and importance, to which they are so justly entitled. To despise, to degrade, and to abuse them, has been the

vo.t. x. 
practice of every nation while it remained in the savage state. Without tenderness, without delicacy, without refinement, the heart of the savage does not look for pleasure in the beauty, chastity, and modesty; in the tenderness, delicacy, and affection; or in the attachment, conversation, and refined manners of the female; but in the labours and menial services she is able to perform. In this stage of society, mar. riage is not a tender attachment, or a union of refined and delicate affections between the sex. es; but altogether an animal inclination, the bare instinct of nature. Placing all excellency in strength and courage, the male views the fe. male as every way inferior to himself; not fitted for honourable employments, but destined to inferior purposes and services. Of consequence, the condition of women in the savage state becomes degraded, mortifying, and sub. ject to servitude. The savage assigns to his wife the care of the children, the business of labouring in the field, and all the services of domestic care and difficulty. Among the Indians, this degradation of the female was carried to its greatest extreme. Every thing most valuable in food, dress, and ornament, was re. served for the man : the most laborious, fatiguing, and disagreeable services, were assigned to the women. Doomed to incessant toil and slavery, the women perform their perpetual tasks without pity, without compassion, without praise, and without the gratitude of their husbands. To this degraded, unhappy state, were the women reduced anong all the Indian. tribes: 
Dress. The same pursuit that supplied the Indian with food, provided also his clothing. This was made of the skins and furs of the ani. mals they took in hunting : these served the purposes of covering, and modesty, none of the northern Indians ever appearing naked. In those nations where opulence and luxury pre. vail, dress becomes a complicated, a profitable, and a curious art: And beauty acquires new force and power, from ornament and fashion. Hence it becomes a most lucrative business in polished societies, to invent and supply the modes, fashions, materials, and ornaments for dress. The savage was not without his taste for ornament, and fashion. His hair was dres. sed in many, and in very singular forms. His nose and ears had pieces of gold, shells, or shining stones, affixed to them. His face and skin were painted, with different colours and figures. And much time was spent to give his countenance the aspect he aimed at. The de. sign of his dress and ornameit was not gallantry to recommend himself to the female, but rather war; to appear the object of dignity, mar jesty, and fear. And what was extremely sin. gular, all the finery and decoration of dress, was reserved for the man. The share that fell to the iroman, was only that which remained, when her husband was completely decked. When he was about to jein the council of his nation, or was going forth to war, he was most of all solicitous to appear in his richest ornaments, and finest decorations. A custom prevailed among the Indians, of rubbing and anointing their bodies with grease, oil, and different kinds 
of gums. These were often mixed with differ ent colours, and formed a very durable paint, or kind of varnish. This may properly be estimated as a part of the Indian dress. And it was well adapted to defend the body, against the extreme moisture and cold of the forest and lake, to protect them against the numerous tribes of insects to which they were exposed, and to check the profuse perspiration to which they were subject, at different times and places.

IDLENESS. When engaged in hunting and war, the savage appears acive, enterprising, and indefatigable. But when these farorite occupations are ended, an universal inactivity, and indolence, take place. The time of the Indian is spent in eating, sleeping; and sitting still. When he applies to any kind of labour, it is with little activity, and with a great aversion. They will spend whole years in making a pipe, forming a canoe, or building a hut. The labours of agriculture, are wholly assigned to the women : Inactive and slothful, the man cannot be roused up to any kind of labour and fatigue. Ilis time is of no value to him : Every thing but hunting and war, is esteemed below his dignity and attention. And of all employments, the lowest and most base, in his view, is digging, toiling, and labouring in the earth. The most indolent, slothful, and contemptible, in civilized nations, have the same idea of honor and industry; that labour, especially agriculture; is beneath their dignity and honor.

Dirtiness. Cleanliness seems to be inseperably connected with industry, and some degrree of refinement. Destitute of both, the sav: 
ages of North America were sunk into the lorrest estate of fith and dirtiness. Nothing can exceed the nastiness that appears in their food, in their cabins, and in their garments. The vessels in which they cook and eat their victuals, are never washed. The dirt and grease in their huts, are never removed or swept away. Their garments are never changed or washed, until they wear to rags, and waste away. No idea of cleanliness seems to have entered into their minds. This seems to be one of the customs, common to all savages : Inactive and lazy, they are all extremely filthy and dirty.

Gaming. Gaming is an amusement, to which indolence and want of employment naturally lead. Above the occupations of labcur, and without a taste for usefis employments, many in civilized life seek a relief in gaming, for the pains of indolence; and for a method, to move and agitate a languid mind. Moved by the same cause and motive, the savage also falls to gaming, as the most favorite amusement; indolent and lifeless in all the exertions of labour, he becomes deeply engaged, impetuous, and noisy in play. Every thing he possesses, is staked at these diversions; and he looses his peace, his senses, and all that he is worth. But these amusements do not issue in contention and quarrels: Though carried on with a frantic eagerness, they are generally managed, and terminate in good humor and peace.

SoNGs. Averse to all abstruse meditations, the Indians are much delighted with songs. To an European ear, their songs do not afford much entertainment; nor can such discern har- 
mony, melody or any variety in their tunes: However this may be, the savages are always delighted with music. Their songs are of a grave and serious turn. They never relate to the concerns of gallantry and love, but to their most serious employments. They have songs for war, songs for victory and songs for death. Each of them is designed to excite and call forth thesen. timents, feelings, and passions, that such occa. sions require; and they have a great influence on their feclings, and actions. Amidst the severest sufferings of death, this is the resort of the savage; and when burring at the stake, the last conso. lation, is to sing the song of triumph and death.

DAsCING. Dancing has been one of the favorite amusements of all nations. In civilized societies this amusement is designed to pro. mote a refinement of manners; and serves to excite the sensibility, and delicacy, which attaches and refines the sexes. Dancing is also the favorite employmert of the savage, in every part of the globe. It calls forth his active pow. ers, which, when unemployed, languish and de. cay for want of exercise. And in no employment, does he become more animated, vigorous, 'and eager. Instead of being an amusement, an affair of gallantry, love, or refinement, dancing, among the savages, is a ceremony of great im. portance and seriousness. With this ceremony war is declared, an embassador is received, and peace is concluded. It is by a dance, that $\mathrm{ev}$ ely important transaction in public or private life, is celebrated. Their dances are generally carried on by the men, and it is but seldom that the women are permitted to join in them, 
All the steps, figures, and motions of the dance, are expressive; and significant of the business or transaction, it is designed to denote. If war is to be proclaimed, the dance is expressive of the resentment and rage they bear to their enemies, and of the hostile manner, in which they mean to treat them. If a party are going forth against their enemies, the dance of war is to be performed. In this, the transactions of the whole campaign are to be expressed. The warriors are represented as departing from their country, entering that of the enemy, surprising and conquering their foes, seiziag prisoners, scalping the dead, and returning in triumph to the applause of their country. The performers appear to be agitated with all the natural pas. sions and feelings, that take place in any of these scenes. The caution, the secrecy, the fwerceness and cruelty of the warriors, is represented in a natural and animated manner. The whole is designed to excite those passions and feelings in the warrior, which it is designed to represent. And so quick, exact, and dreadful, is the representation, that the uninformed spec. tator is struck with horror, and looks to see the ground covered with mangled limbs, and slaughtered bodies. If peace is made, this is also celebrated by a dance. The ambassadors and the warriors smoke in the same pipe, and join together in the same dance. The dance is adapted to signify that the hatchet is buried, that the blood is all washed away, and that the ghosts of the slain are appeased, and at rest; and that both nations are now to live, in all the friendship and familiarity of brotherhood. 
Thus instead of baing barely an amusement and diversion, dancing among the Indians, is a very in portant and significant ceremony ; designedto represent some important transaction, and to ingrive those feclings and passions, which it

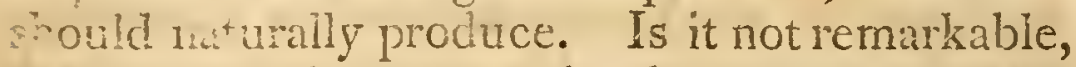
ati amorg the savages in the first stage of socicty. dancing should be adapted to public and renowi purposes; that all the steps, figures, and motions of it, should be arts of imitation; 6. Wat among cirilized nations, all the steps z. acions should be without design, insignificant and without any meaning ate all ?

BuARD. The customs and methods of dif. fere it nutions, have been various and different; rcspesting their beards. Some have carefully prescrved them as the tokens of manhood, gravi. ty. and mujesty. Others have curled, twisted, and braided them, to give the appearance of elegance and beauty: Others have entirely cut them off, as an uscless encumbrance; and to acquire greater softness, mildness, and amiable. ness of appearance. These different customs and fashions, do not appear to be derived from any permanent cause, or instinct founded in nature; but to be matters of fancy, superstition, convenience, or vanity. In this respect the Indians had a custom different frem those of other nations. $I t$ is their universal and constant practice, to pluck them out by the roots; and to destroy, as far as possible, the appearance of any beard at all. Every man has an instrument made for this purpose : It consists of a wire, twisted round a stick, in such a manner as to draw the hair out of the fesh, and extract the 
root. The Indian carries such an instrument with him: And it makes a regular and constant part, of what he esteems his dress, to extract and destroy his beard. So fond are they of this custom, that whenever the Indian can obtain a looking-glass, his first business is to examine his face, and with this kind of tweezer, pluck out all the hairs he can discover. They generally recommend this custom to their captives, as what would increase their beauty, and destroy. their hairy appearance, which the savage greatly dislikes.

Some philosophers have supposed, that the beardless countenance of the Indian, is derived not from custom, but from nature: That the Indian is without any beard, or hair on any part of his body, except the eyebrows and head: That this arises from a defect in the powers and vigour of nature; and is an evidence of weakness, impotency, and want of manhood.* The fact and the conclusion, are both mistakes. Nature is the same in the Indian, as it is in the European : And on whatever part of the body it has assigned hair to the one, it has given it to the other. I am assured of this from those who have slain, stripped, and buried their warriors : I have the same information from those, who have been their captives; and who have seen all the members of an Indian family, dressed and undressed, and in all situations. The same is asserted by those, who have lived among the civilized tribes, and been called to perform offees of humanity, to the Indians of each sex.

* Buffon, Kaims, Robestron, \&c.

VOL. In

Z 
"The beardless countenance of the Indian then, is not to be ranked among the curious and ex. traordinary phenomena of nature, bit is to be placed among the customs peculiar to the Indian tribes.

DrunisenNess. Diuntenness is one of those rices, which preval among; a rucle and uncultivated people. The savages of North America, are universally addicted to it. Before they were acquininted with the Europeans, they had discovered a composition, or liquor, of an incbriating nature, made out of maize or Indian corn. But the difficulty of procuring a large quantity of this liquor, prevented any general intemperance, or excess.

No sooner had they tasted of the spirituous liguors brought by the Europeans, than they contracted a now appetite, which they were wholly unable to govern. The Europeans found it the most lucrative branch of the fndian trade, to gratify this inclination. With an avidity of desire altogether uncontroulable, the Indians fell into the snare. The first object of inquiry with them, was, whether the tracler had brought. any brandy or rum ; and no considerations could restrain them in the use of it. "The old and the young, the sachem, the warrior, and the women, whenerer they can obtain strong liquors, indulge themselves without moderation, and without decency, until universal drunkenness takes place. All the tribes whether placed in a temperate, or in a severe climate, appear to be inder the dominion, and unable to govern this appetite. An effect so universal and similar; must have as general \& universal a cause. The cause 
will be found to have a deep and a strong foundation, in their manner, custom, and habit of living. Their constant method of living, was on raw or boiled meat, and fresh water. This did not satisfy the desires of nature; and naturally produced an appetite for every thing, which was astringent, stimulating, and infammitory. When they met with ardent spirit, they found that, which is the most highly gratifying to such an appetite. The hardships and sufferings to which the Indian was exposed, their want of comfortable refreshments and support, and the extremes of heat, cold, and moisture, to which they were subject, were constantly adding new force, to an appetite already excessive. Few of the white people, who have been reduced to such a situation for a few months, have been able to preserve their tem. perance. The Indian proved wholly inadequate to the trial. Unaccustomed to lay any restraint on his appetites and passions, and unable to bear but a small quantity of the liquor, to which he had been unused, he is overcome upon the first trial. His appetite, the more inflamed by irregular enjoyment, becomes more keen and raging, until extreme excess puts it out of his power to indulge himself any longer. Nothing but a total change of the whole method of his living, will enable him to preserve that temperance and regularity, which to a person surrounded with all the comforts of life, is an easy and a common attainment.

CRUELTY. There are no passions in the human mind, which operate with so much force and frerceness, as those of anger and revenge. The 
customs and maxims of polished societies, with all the aid of their laws and religion, have not as yet been able to give a due regulation or restraint to these passions. In many cases, an offended individual camnot be made to believe, but what it is right and best for him, to be the judge and the avenger of his own injuries; and that it is the mark of meanness, to leave it to the laws of society, to make a proper retaliation for the wrongs he has received. Higher attainments must yet be made in the state of so. ciety, before an adequate restraint and regulation will be found for these passions. In the breast of a savage, they rage without any controul: Instead of being taught any restraint, the young savage is taught in early life, to gratify and induige them. The whole force of educa. tion, example, custom, habit and manner of living, operate with a decisive influence, to give them new force and vigour. By the govern. ment of the tribe, the revenge of injuries is left in the hands of every individual ; and to be patient and moderate, is the highest mark of meamness and want of spirit. To give further force to the spirit of vengeance, all the maxims and customs of war, have placed the point of honour, in rendering the spirit of revenge, im. placable, unabating, and such as never can be satisfied, subdued or lost. Aided by all these motives and considerations, anger and revenge, become fierce, brutal, horrid, bloody, and impla. cable passions, in the breast of the savage: More like the destructive rage of a beast of prey, than like a passion in the heart of a human. being, The effect, is a barbarous and unre. 


\section{HISTORY OF VERMONT. 193}

Ienting cruelty : Far from pitying, sparing, or forgiving, the savage aims at the ruin, destruction, and utter extermination of his enemies. Hence the method of carrying on his war, was to destroy men, women, and children. To plunder and burn their towns, and villages: To torture and torment their prisoners: And to sweep off whole tribes, with an universal and undistinguished carnage. This seems to have been the wish and aim of every tribe, when they engaged in war. A barbarous, unrelenting cruelty, distinguished and marked all their steps.

THE cruelty of the Indian seems to have arisen from the passions of anger and revenge. It is not to be denied but that there are other passions, which have carried civilized nations, to the same dreadful extremes in cruelty. Avarice led the Spaniards to perpetrate more enormous crimes and cruelty upon the Indians, than the Indians were ever capable of returning. The scene of promiscuous calamity, destruction, murder, and butchery, which the Spaniards carried through all parts of South America, in the number, design, degree, duration, variety, and enormity of its cruelties, far cxceeded any thing that was ever perpetrated by the Indians. If we are to believe the declarations of 'a celebrated modern Statesman, * the avarice of a com. pany of merchants, has murdered millions and millions of mankind, by starving them to death in Bengal. The spirit of superstition and bigotry, is equally cruel and unrelenting. The 
murders of the inquisition subsisted for centuries: they were sunctioned by law, and are not yet done away. Imprisonment, confiscation, and death in its most awful forms, were the punishments which bigots, whenever they had power, never failed to inflict with great pleasure, upon those who were wise and virtuous enough to oppose them. The massacre on St. Bartholomew's day, in 1572, was one of the most barbarous and horrid of all human transactions. In the midst of the most polite city in Europe, the king, "princes, nobility, and priests, turned monsters, assassins, and butchers; and murciered thirty thousand of their fellow men, on account of their religion. Their rage was attended with circumstances of inhuman cruelty and babarity, far excceding the fierce and bloody passions of the sarages of $\mathrm{A}$. merica. Our own countrymen ought not to forget, that revenge has also transported them into a conduct, equally inhuman and barbarous as that of the Indians. At the conclusion of the Indian war, in 1576, the government tried several of their captives, by the English laws: Some were condcrned, and executed upon the gallows; and others were sent to consume their days, in the slavery of the VVest India Islands: A punishment, to them more severe than death. Is the cruelty and barbarity of the Indian, man appears in a situation but little remored from the brutal ferocity of the beast of prey. But when avarice, bigotry, and revenge, pro. duce the sane infemal spirit among civilized nations, cruelty appears with a more diabolical aspect; not like the rage of wild beasts, but 


\section{HISTORY OF TERMONT.}

like the fury and vengeance of a combination of apostate spirits. The prosress of knowledge, humanity, and refinement, will afford the only effectual remedy for this evil.

SucH were the regulations, customs, and manners of the Indians, the original men of America. They have been vicwed by philoso. phers, in the most opposite and contrary lights. Some have supposed that the Indians were in the infancy of existence, that the whole contincnt of America was but lately raised out of the sea, and that her inhabitants ivere in a state of degradation, unworthy to be compared with the men of the more ancient and improved hemisphere.* On the contrary, others have contended that in the rudest and most simple state, man attains an independence, a dignity, and a nobleness of mind, which is never found, but is always lost, amidst the refinements of polished societies : that the highest dignity and nobleness of man, is derived solely from nature, and is always debased and corrupted by polish, refinement, and the arts. $t$ To view this subject in its proper light, it will be necessary to compare the savage with the civilized state, and to mark the various Advantages and Disadvantages of it.

The Savage State favourabie to the Health, Activity, and Vigour of the BODY. Among the advantages that were con. nected with the savage state, it may justly be esteemed one, and a matter of much importance, that it was favourable to the vigour, activity, 
and health of the body. It is by exertion and exercise, that the body acquires its most improved state of activity, firmess, vigour, and health. Accustomed to range the forests in quest of game, the Indian acquired an habit and activity in travelling, that exceeded that of any other people. In the expedition, swiftness and perseverance of his course, he much exceeds the European. No people bear hardship, sufiering, and fatigue so well: The extremities of heat and cold, of hunger and thirst, of bad weather, and of bad accommoda. tions, are perfectiy familiar to the Indian: And he bears them with a much less effect upon his constitution, than the men who have been used to better accommodations. Jnaccustomed to the steady and regular employments of agriculture, his body does not acquire the strength that the Europeanshave. And when the exertion, is anex. ertion of strength, and steady labour, the white man is found to be the strongest. Those only of the Indians, who have been educated and trained up to steady and hard work, are equal to the white men in bodily strength. In running the race, and in bearing hardship, the Indian exceeds; but in strength of body, and bearing hard and stead labour, he is generally unequal to the European.

In respect to health, the savage state seems fully equal to the cirilized. Used to all the variations of the weather and climate, he suffered but little from such changes. The diseases to which the Indians were subject, were chiefly those which arose from exercise, hardships, and fatigues. Fevers, the asthma, and paralytic 
disorders, made the capital articles in the histo. ry of the Indian diseases. But that numerous and fearful train of maladies, which arise from luxury, sloth, intemperance, and want of exercise, were unnamed, and unknown among the Indian tribes. In their villages there seemed to be a greater number of decayed and aged persons, than are generally to be found among an equal number of white people. But as they had not the art of numbers and computation, no exact accounts could be procured of their age. This article rests therefore rather upon appearance, and indication derived from decrepit and shrivelled bodies, than from any proper and authentic accounts of the years and longevi. ty to which they attain. All appearances howerer seem to indicate, that activity, vigour, health, and age, were to be found to great advantage in the savage state.

Favourabie to Firmess and FortiTUDE OF MIND. The situation and employment that promoted the vigour and health of the body, tended to produce independence, firmness, and fortitude in the mind. Inured to suffering, hardship, and danger, the mind of the savage was formed to an habitual firmness and courage. His mind became composed and collecied in critical and dangerous situations : And he suffered but little from apprchensions of fear. The spirit of freedom and independence was cultivated and confirmed by every circumstance attending his education, cmployment, and reputation. Neither corrected nor checked in his early years, retarded or stopped in any pursuit, he knew of no controul or restraint....

$$
\text { YOL. I. A } 2
$$


Master of his own actions, and never wishing to moderate his passions, the spirit of frecdom and independence tonk the entire possession of his soul. Mured by and perpetually conscious of this indepondient spirit, he acted in circumstances of distress and danger, with amazing force and magnanimity of mind. But that which the savage esteemed his greatest glory and highest elignity, was his fortitude and bravery. To beir hardship, to endure stifing, in be unmored in the midst cf toment, and to rise supcrior to any thing that could be laid upon him; this, was the highest honour, and the moblest attainment of the warrion. And in this, it is not to be denied, that the human mind attained-in the savage state, a fortitude and a magnanimity that it does not attain, amidst the refinements, custons, and maxims of polished nations.

Amazed at the firmness and fortitude, which the savage displays in the most dreadful of all situations, severai philosophers have aimed to discover some apathy, some natural defect, or want of sensibility in his frame, which qualified him to bear pain with less feeling, and with more fortitude, than other men. There is no such defect in his constitution. His magnanimity arises from a sense and princiv!e chinnour. This is the first principle he is taught; the sole object of his education, profession, and pursuit. Amidst the rudeness and hardinood of the savage state, this principle acts with morc. force and vigour upon the human mind, than it ever acquires amidst the refirements and softness of a more polished state of society. 
Refinement, and the arts, soften and relax the mind; philosophy debilitates the body, while it aims to correct all rudeness and excess in the mind, and to give it a just habit and tone of thinking and acting: But in the rudeness of the savage state, every thing concurs to give an unaltered firmness to the body, and to the mind; the principle of honour has nothing to oppose or relax it: Ard it will be in the most hardy body and mind, that nature and honour will act with the greatest force and vigour. The principles of religion only, have ever produecd a similar phenomenon. The heroic spirit of the martyr, undaunted and triumphant in the torture, and in the flame, has alone exceeded or equalled the fortitude and magnanimity of the man of nature.

Favourable to Poittical talents, AND VIRTUEs. The savage state was also friendly to some of the political talents and virtues. The love of his country, derived from nature, cherished by education, ambition, precept, and example, became a very powerfui principle in the breast of a savage. His affecticns were confined to the limits of his own tribe, and his views never extended any further. His glory terminated in the services he could reader to it: And the greatest of all attainments was to expand the national fame, reputation, and conquests. Wo this he became attached by birth, education, and interest; by ambition, honour, and a thirst for glory, Every passion that glowed in the breast of the savage, served to increase and add strength to the love of his country. No motives of ambition, gain, re. 
venge, or policy, ever lead him to betray its interests or conncils, to desert to the eneny, or to prove a traitor to the country and tribe, that gave him birh. Whis principle connected together the members of the saric tribe: It scems to have taken the deepest root, to have acted with the greatest force, and to have been the least corrupted, in the savage state.

Wris the interests of their conintry were to be considered, much fruclence and wiscom were displayed in their counciis. The chiefs and elders consulted with great delibcration, serious. ness, and calmness; and rithout any appear. ance of provocation, rescntincui, or impatience at contradiction and opposition. Every propo. sal was considered; the probuble efiects and consequences, advantages and disadrantages, were examined and weighed. No heat, anger, ill nature, or renections upon one another, but perfeet calmness prevailed: And that conclusion was embraced, which appeared to be most beneficial to the tribe. Those of the Europe. ans who have attended these councils of the savages, have compared them to the accounts, historians have given us, of the prececdings of the senates in the ancicnt republics, $*$ rhey bore the appearance of solcmnity, swavity, and deliberation. In these councils, imtegrity and public virutue was always preserved. Ylic ob. jects they had to determine, were not of a trivial or insignificant nature : they were those, which involve all that is the most clear, valuable, and important to man, in any stage of socicty : The.

* Charlevoixuii. 26. Smith's Hist. Ncwyorig, P. 53 . Pail. Edit. 


\section{HISTORY OF VERMONT. 201}

preservation and protection of their property ; the safety and the lives of their wives, children, and fathers; the existence, the independence, and the freedom of their country. The councils of civilized nations may be employed upon objects of a much greater extent; but they never can contemplate objects of more importance, of greater value, or of a higher nature. In attending to them the mind of the savage became composed, sedate, grave, and scrious. He had no private interest to corrupt him ; no broken fortune to be repaired; nothing to be expected from the misfortunes of his country; from lucrative jobs, posts of honour and profit; fiom the management of the public wealth; or from the weakness, prejudice, and favourite passions of a prince. No emoluments or advantages could accrue to him, but those of the public good. In such a situation, corruption would not enter into the councils of the savages. There was nothing to be gained by intrigue, dissinulation, or knavery. All the advantages that could arise to individuals, must arise from the general good of the tribe. And where there was nothing to be gained by corruption, there was nothing left for their counsellors, but to display their grcatest wisdom, integrity, and public rirtue.

The nature of their government and councils was also favourable to eloquence, and the art of public speaking: This seems to have been the only art, in which the Indian rose to any eminence. Unable to remember an irregular unconnected discourse, the Indian was extremely fond of regularity and method. When he spoke, 
his speceh was short and laconic ; and the meaning was conveyed in bold and strong metaphors. When they return an answer, they repeat the whole that has beein said to them, and reduce it into a strict and regular order. Their words are but few; the language strong; and figurative; the figures expressive, vigorous, and bold; thcir manner, grave and animating; the tone, determined and decisive; and the sentiment they mean to convey, so clearly expressed, that they are never misunderstood. An historian who was present at sevial of their conferences with the English, gives this account of the appearance and manners of their orators, "Their speakers deliver thenselves with surprising force, and great propriety of gesture. 'The fierceness of their countenances, the flowing blanket, elerated tone, naked arm, and erect stature, with a half circle of auclitors seated on the grround, and in the open air, camnot but impress upon the mind, a lively idea of the ancient orators of Greece and Rome."* Some of their speeches in manliness of sentinent, in the force of expression, and in the elegance of the arrangement, have been fully cqual to the productions of the Grecian, Roman, or British eloquence. And in no case does language acquire such force and rigour, as when it is the dictate of the passions and feelings of nature, in her rude and uncultivated state.

It was by the combination of these virtues and abilities, that the savage rose to public honours, employment, and distinction. The brar- 


\section{HISTORY OF VERMON'T. ZOB}

est and the wisest became the leader, and the sachem. No other arts could secure the public esteem and favour, but superior abilities and exploits. The ancients generally numbered good fortune, among the most necessary qualifications of their heroes. The Indians adopted this idea in its full force, and extent. ' Without distinguished bravery and success, the private man was never promoted at all : If he proved an unfortunate and unsuccessful lcader, he soon lost all his infuence and reputation.

In these maxims and customs of the savage state, there were constant and powerful motives, to the exertion of all their political talents and virtues: And there was much less intrigue and corruption in those public proceedings, which related to their own tribe, than there generally is in the transactions of civilized societies.

Favourable to the ExERCISE OF SOME VIRTUZs. Several of the vices that prevail among polished nations, were seldom to be found among the Indians ; and there were some virtues, to the exercise of which, the savage state was not unfriendly. The hospitality which the ancients celebrated so much, was of great importance and use in the early stages of society. When the stranger and traveller could find no accommodation or protection, but in the kindness of those on whom he called for relief, hospitality became a virtue of the highest use and excellency : the business and convenience of life, could not have been easily carried on without it. As society became improved, the stranger found in the protection of laws, and in the use of money, that relief, which he before de- 
rived from the hospitality of the age. In pol. ished nations, the necessity and the existence of this virtue, have in a great measure ceased. Among the savages it prevailed to an high degree, and acted with its full force. The Europeans every where found the most friendly and cordial reception, when they first came among the savages; and from their hospitality, they derived all the assistance the sa vages could afford them. It was not until disputes and differences had taken place, that the Indians became unfriendly. Even now, an unarmed defenceless stranger, that repairs to them for re. lief and protection, is sure to find safety and assistance in their hospitality. The friendship of the Indian, is always a rery strong and vigorous affection. Ilis passions unsubdued, undisciplined, and ungorerned, always act with great force and vigour : rintever be the object of them, the passion itself is always impernous and strong. No bounds are set to his resentment and revenge, when injured; and no length of time, will obliterate the memory of a favour. The same impetuosity and perseverance, with which he pursues his enemy, is emplored to assist and preserve his friend. In this respect, the Indian attachments have fully equalled any thing that is to be found, in the history of man. Several of their best concerted expeclitions have failed, through the anxiety of an indiviclual to preserve a friend from the common vengeance and destruction.

TRAINED up to the most refined cumning and dissimulation in war, the Indian carries nothing of this into the aftilis of commerce; 


\section{HISTORY OF VERMONT. $20 \%$}

but is fair, open; and honest in his trade. He was accustomed to no falsehood or deception; in the management of his barter. And he was astonished at the deceit, knavery, and fraud of the European traders. He had no bolts or locks to guard against stealing, nor did he ever conceive his property was in any danger of being stolen, by any of his tribe. All that train of infamous and unmanly vices, which arise from avarice, were almost unknown to the sav: age state. Lying and falsehood were viewed with horror; and detestation. When they found these vices common among some of the Europeans, the Indians viewed them as a corrupt and odious race; in whose truth, justice, and declarations; no faith could be placed. They had no name for adultery, or rape. Quarrellings. contention, and discord, with their numerous ill effecis, were but little known among the members of the same tribe.

ThEIR morality, confined to a few objects; adnitted of fewer vices than the civilized state. Where no wants are known but those of nature; and the way to supply those wants is the same and open to all; the individuals of the same society, will live in a friendly and cordial manner together; without many grounds of strife, and without much temptation to injure each other. In the language of the Indians, this is denominated a state of brotherhood: In this state, the moral sense will join its influence with the social affections, to prevent injuries, evils, and vices; and to restrain the members of the tribe, from violating the rules of morality. As such a state does not admit of many of the virtues of VOI. I.

B 2 
civilized nations, it is also in a great measure free, from many of their most dangerous vices.

IN such respects, the savage state seems to have had advantages peculiar to itself; and to have produced effects, which are not to be ex: pected among civilized nations. But before we decide on its operation and tendency, it will be necessary to examine the disadvantages, to which it is subject ; with their influence, and effect on society.

The Savage state unfavorable to ali Inteliectual Improvements. As. one disadvantage of the savage state, it has constantly proved unfavourable to all intellectual improvements and exertions. Occupied solely with hunting and war, the savage had no idea or wish for any intellectual attainment, which was not immediately connected with his favourite professions. Neither his reason, nor his invention, appear to have been much exercised upon any object, not suggested by his necessities. Taking the game, and subduing his enemy, did not depend on the knowledge of letters. The transactions of his ancestors, were not of much importance to him : He had no code of laws, no evidences of property, or any public transactions to be rccorded. With these arts, of so much importance to civilized nations, but of little consequence to the Indians, they were wholly unacquainted; and had not made any advance towards the discovery of letters. The only thing which they appeared anxious to record, was the exploits of their warriors. When a party of these had met with uncommon success, it was often the case that they made some 
very rough figures or inscriptions upon the trees, to represent the direction of their march, the number of enemies which they had slain, and taken captive.* These kind of inscriptions were sometimes made upon the rocks; but they were not confined to the affairs of war. At West river in this state, near its entrance into Connecticut river, several of these inscriptions yet remain. They are irregularly placed, and rudely scratched upon a rock, and but little sunk below its surface. Four of them seem designed to represent the wild duck, and the fifth was probably designed for a fox or wolf. At Bellow's falls in Rockingham there are several figures of a superior work. They amount to ten or twelve in number, and are wrought into the surface of the rock. These inscriptions represent a number of heads; some of men, some of women, some of children, and some of other animals. The outlines of these figures are aukward and ill executed, but they are sunk into the rock at least one third of an incl in depth. How long they have been there, or what transactions they were intended to repre sent, no tradition gives us any account; but their rudeness and awkwardness denote that the formers of them were at a great remove from the knowledge of any alphabet. The art of numbering and computation, is an elementary and essential art in every nation where business is transacted, or any considerable intercourse and commerce is carried on. But the savage had nothing to number, that was of much im- 
portance to him. He had no treasures to count; no property, the value of which, was to be computed; nor any varicty of objects, the number and value of which, must be expressed by fig: ures. Arithmetic would therefore have been an useless art to the Indian; and he had not made any attempt to attain it. They could count as far as ten or twenty ; all beyond this, was compared to the number of the trees, or: the hair on their heads. The only objects, on which the Indian haç employed his reason, were those of external sense ; such as are material or corporal, the idea of which is received by the senses. They had no name for any of the sciences, or for abstract and universal ideas. Time, space, duration, substance, and all those terms, which are used to represent abstract and universal ideas, appear to have been unknown ; and probably never were the objects of their inquiry, contemplation, or thought.

THE ideas of religion, were extremely weak and obscure in the savage. Our Maker. has not left us to a course of metaphysical reasoning upon the connexion between cause and cffect, to come to the knowiedge of his existence. Long before men become capable of such excrcises of the reasoning powers, they believe in the existence of a Deitry. A sense of his being, seems to be inscribed upan the human mind. And probably no tribe has ever been found, that had not the idea of some superior powerful being. Whether this was the object of fear, or of love, or however it was represented, the idea of a superior being seems to have been common and general among all nations. It takes place 
in the mind, before we are capable of reasoning about cause and effect: And it seems to be derived from a revelation, which the Deity hath made of himself to man. In the constitution of the human mind, in its feelings, passions and motions, a sense of the Deity seems to be in. terwoven, instamped, and inscribed. And this revelation becomes more clear, plain, aud intelligible, according to the manner and degree in which it is improved, Among the Indians, it appeared in its weakest and most obscure state. They denominated the Deity, the Great Spirit, the Great Man above; and seemed to have some general, but very obscure ideas of his government, providenee, universal power, and dominion.

THE immortality of the soul, was every where admitted among the Indian tribes. The sentiment itself results from our fears, hopes, and feelings. Man is scarcely ever degraded and sunk so low, but that he hopes and believes that death will not prove the extinction of his being. This sentiment prevailed in every part of Arnerica. The Indians so firmly believed it, that it was their general custom to bury with the dead, their bows, their arrows, their spears, and some venison, that they might not be wholly unprepared to begin their course with advantage, in another state. There might be a few exceptions, but the general sentiment was nearly the same in every part of the continent.

Bur both these sentiments, the existence of a God, and the immortality of the soul, were nothing more in the savage, than the dictate and voice of nature. They were not the object of 
his inquiry, discourse, reasoning, or contempla. tion. The Inciians had made no improvements, no cultivation of the gifts of nature and providence ; and they had very little influence on any part of his conduct. 'They had not produced any domestic, or public devotion; any form, rite, or mode of worship; or any system of manners and customs, favourable to national virtue and religion. Without a priest, without a temple, sacrifice, or altar, the Indian was sunk under the thickest glcom of ignorance, superstition, and stupidity.

His reason, never employed on any intellectual attainment or exertion, he remained in á state of nature; wholly unacquainted with every thing derived from the exercise, improvement, and cultivation of the powers of the mind. Neither his reason, or his desires, ever moved or tended towards any such improvements : And so long as hunting should have continued to be the mode of his subsistence, so long it is probable, he would have remained at a distance from every intellectual attainment.

Admits of but Feiv Virtues. It was another disadvantage of the savage state, that it did not admit of but few virtues. The moral sense, or conscience, makes part of our natural constitution; and is as essential to man, as his appetites and passions, as his countenance and form. When this is not corrupted or perverted, its dictates are clear and right, and do not tend to mislead us : And its dictates are never more clear and certain, than when they are the genuine and simple voice of nature. There were fewer temptations and there were fewer vices in 
the savage state, to corrupt and pervert the moral sense, than there are in a polished state of society : But there were also fewer motives, occasions, and opportunitics for virtue. Reverence and respect to the Deity, had little place or effect on the uncultivated mind of the savage. There was nothing in his situation to produce those offices of kindness, and tenderness, which soften the heart, and swecten the intercourse of life, in the civilized state. The sullen pride of independence, was the strongest passion in the heart of the Indian; and it left but little room for tender and generous affections to others. Depending solely upon himself, the heart of the savage contracts an insensibility, an hardness, a roughness, very unfavorable to social connexions. Expecting no offices of kindness from others, he was very little employed in relieving the distresses, supplying the wants, or gratifying the desires of others. In a heart thus contracted, but few virtues will reside. The natural affections will remain, and may become strong and vigorous: But the divine, social, and human virtues, find an unfriendly soil; become few in their number, and weak in their operation.

No Attainment in the Arts. Those arts, which are the most necessary and useful to men in the civil state, were almost wholly unknown among the savages. To provide a covcring to defend the body against heat, cold, and moisture, is one of the first arts that man must have attended to. The Indian had gone no further in this primary and essential art, than to apply the skins and furs of animals to this pur- 
pose. The art of spinning, knitting, and weav: ing, were wholly unknown to the northern Indians. They had no other materials to cover and clothe their bodies, than what were derived from hunting. Architecture of some kind and form, must unavoidably engage the attention of men, in every climate and country. The attainments of the Indians in this art, were the lowest that can be conceived. Their buildings were nothing more than a few temporary and wretehed huts, put together without order, strength, or convenience: Some crotched stakes were thrust into the ground : these were connected by poles, laid from the one to the other; and the whole was covered with the bark, limbs, and leaves of the trees. An aperture was leit at the top, for the conveyance of smoke; and the fire was kindled in the middle. This was called a cabin or wigwam, and was without windows, doors, or any division of apartments. This was the highest elegance and convenience, the house of the Indian had attained.

The progress of the arts, depends very much on the instruments and tools, with which the artificers are furnished. Most of these among civilized nations are derived from the application, and use of the metals; particularly that of iron. From this metal is formed almost every instrument, that is employed in peace or in war. Civilized nations have availed themselves of the discovery and use of this metal, in every kind of art that they pursue. The Indian was in no capacity to arrive to such an improvement. Copper, silver, and gold, have been found in their perfect state, in the rocks, mountains, and 
ivers; and were the metals, which were first known and used. But nature never completes the formation of iron. It must pass through two or three tedious operations by fire, before it appears in its perfect and useful form. With the former metals, the Indians in some parts of America, were well acquainted: But of the nature and use of iron, all of them were wholly ignorant. Destitute of this capital advantage, all their tools and instruments to an European, would have been wholly useless. Their axe was made of a sharpened stone. Their knife was formed out of a shell, or bone. Every oth. er instrument was equally impotent, and ill contrived. The arms they had contrived for de. fence or attack, were equally feeble and awkward : A club made of hard wood, a stake hardened in the fire, a lance armed with a flint or a bone, a bow and an arrow, constituted the whole artillery of an Indian war. Of domestic utensils and household furniture, they had nothing that deserved the name. A bed, a chair, a table, 2 pot, a kettle, or an oven, were wholly unknown. Their bread was baked on the coals. Their meat was broiled in the same manner. Their greatest art in cookery, was their method of boiling their food. A picce of wood, or a stone, with extreme labour, was formed into a hollow, and filled with watcr; and this water was made to boil, by throwing into it stones heated red hot.

THE greatest performance of the Indian genius, was the construction of his canoe. With infinite labour, they sometimes hollowed out a tree, and gave it a form adapted to the purpose

- 0 L. I.

C 2 
of navigation. In a canoe thus formed, four or five Indians wonld pass a river, a large lake, or a dangerous rapid, with much safety, and dexterity. Another kind of canoe, was formed out of the bark of the elm, or birch. This was the work of but a few days, and was extremely light and convenient. It was of sufficient di. mensions, to carry four or five Indians ; and so light, that one of them could easily carry it on his back. The dexterity of his management, the swiftness of his royage, and the safety with which the Indians pass the falls, rapids, and waves in this kind of boat, has appeared surprising to those persons, who were best acquainted with the arts of navigation. And it seems to have been the highest attainment, to which the genius or invention of the Indian, had ever arisen.

In the application and use of particular ve. getable, animal, and mineral substances, the Indians seem to have had some information, which ought to have been more attended to, and better ascertained. They certainly knew of some substances, which gave the most vivid and permanent colours; and of others which contained the most subtle, active, and powerful poisons. In several cases of poisons, wounds, and some other disorders, the Indians had the knowledge of very valuable medicines : And they derived support, refreshment, and medicine, from several plants and vegetables, in which the English had not discovered any such virtues or qualities. The knowledge of such facts, was the result of such observations, as experience ngaturally produced. But as the Indian never 
attempted to improve any information which he had, and knew of no method to preserve it but tradition, he made small advances in this kind of knowledge ; and it was rather a matter of secrecy, than of investigation. Nor was there any thing in his situation, or employment, adapted to call forth the latent powers of his mind, and to produce the spirit of inquiry and improvement.

Very Unfavourable to Population. A clisadvantage still more unfavourable attended the savage state, it tended much to retard population. From the earliest histories of Virginia, it has been computed that the number of In. dians in that part of the continent, did not amount to more than one for every square mile.** I do not find any account, which will lead us to estimate the number of Indians in New England, at a higher ratio than this. In those parts of the United States where the farms are well managed, a farm of one hundred acres will well support a family of ten persons. This amounts to sixty four persons, on one square mile. The Indian population then, compared to what has already taken place in those parts of the United States, which are well settled and cultivated, was in no higher a proportion than one to sixty four. A difference so unfavourable to the production of life, denotes some essential defect in the savage state.

Population depends upon a variety of cir. cumstances, all of which are never found to concur, in favour of any people. In the state 
and situation of the Indians, there were ferver circumstances favourable to population, than in any other state of society. In the constitution, form, and vigour of his body, nature was bountiful to the Indian. In the dimensions and size of his body, in the proportion and perfection of all his limbs, members, and organs, he rather exceeded than fell short of the European. All that have been acquainted with the savages, have been struck with this circumstance. In no race of men, has the human body appeared to be better formed, more nicely adjusted, or to be more perfectly proportioned in all its mem. bers and parts. No deficiency therefore arose from any impotency, or want of rigour, in any of the powers of nature.

But whatever may be the original poriers of nature, they are weakened and impaired without proper food, and nourisment: And it is only, where suitable and nutritive food is to be obtained in regular and sufficient quantities, that animals will become the most prolific. In this respect, the situation and state of the savage, was greatly unfavourable to increase and popu lation. Destitute of any certain or regular food and nourishment, the Indians suffered severely this way. At one period, all was gluttony and excess; at another, famine and hunger became extreme and distressing. The heaviest part of this distress fell upon the women, who were the least able to bear it: And at no time did they enjoy that regular and steady supply of food. which naturc required. In the male, this tended to impail the animal passion : In the female, it tended not only to weaken it: but to rencter it 
grreatly dangerous to indulgुe it. Its effects were still worse upon the pregnant; and often destroyed the increase and fruit of nature, before. the birth.

THE manner in which the Indians procured their food, was equally unfavourable to population, as the uncertainty and irregularity of it. Destitute of a fixed scttlement and abode, the savage spent the hunting season in wandering through the forests in quest of game, and generally carried his family with him. Their women must climb the mountains, wade through the rivers, force their way in the thickets of the forest, sleep upon the wet ground in the open air, and carry their children with them ; and amidst all these fatigues and distresses, were often without food for several days, and always without comfortable refreshment. Instead of being in any degree prolific, the white women. would have all perished in such a situation. The wonder is, not why population should have been so small, but how it should subsist at all, in such a situation. If the constitution of the. savage had not been uncommonly strong and vigorous, not only the animal passion, but all the powers of nature would have ceased and become extinct, by such continued scenes of fatigue and distress.

THE constancy and perpetuity of their wars, had also a fatal infuence on population. The. irruption of an enemy desolated their cultivated lands, disturbed them in their hunting exertions, and destroyed all the little stock of provi. sions they had saved. The women and chisdren had no place of refuge, but to conceal 
themselves in the woods, and mountains; where many of them must perish for want of food, and all of them must be in a suffering and dis. tressed condition. In the whole catalogue of human woes, it is not possible to conceive of any state more distressing, than that of a pregnant woman, in a situation so horrid and awful. Many of them lived, and brought forth the fruit of hature, amidst this complication of miseries. But the preservation of the mother and child approached nearer to the nature of a miracle, than to what is esteemed the effect of the established and regular laws of nature, in the civiliz. ed state. While their wars had this fatal tendency to prevent the increase, they operated with a force equally fatal, to destroy and sweep of those that were the most vigorous and active. Revenge, destruction, the utter extermination of an enemy, was the object aimed at in an Indian war: And while it was carried on, it operated and raged with a fatal and a certain tendency, to efrect its design, aim, and end.

Other causes might be found, in the cus. toms, manners, and maxims of the savages, which were also unfavourable to increase and multiplication; but it is not necessary to enumerate every particular, that would apply to this subject. The eircumstances which have been mentioned, are sufficient to account for all that has been uncommon, in the defect of Indian population. That these circumstances, do in fact contain the causes, which rendered the population so small among the savages, is confrmed from this additional evidence. Wher. ever the Indians have been placed in a situation 
favourable to increase, they have become equal. ly prolific as the descendants of Europe. Seve. ral of the traders among the Indian tribes, have married with their women: When the Indian women have been thus provided with comfortable food, raiment, and places of abode, and relieved from the fatigues and distresses of the savage state, they have raised up as large and numerous families, as are found in the houses of the white people. And among themselves, when a tribe was situated on the bank of a river abounding with fish, or in a spot where the game was plenty, and they remained undisturbed by their enemies; their numbers soon increased, their women became more valued and esteemed, and population assumed a greater force and vigour.

In some parts of America, the Indians had advanced beyond the savage state, and acquired some of the arts and conveniences of the civil state. In such places, the same increase of numbers took place among them, that is seen among other nations. The intercourse between the sexes approached nearer to delicacy and refinement. Greater attention was paid to the women. The men became sensible, how much their happiness might be promoted, by the attachment and tenderness of the female. In the empires of Peru and Mexico, the Indians had made considerable adrances to such a state: And their population had become vigorous and rapid. Their numbers resenbled the appearance of things in Europe; and their cities abounded with inhabitants. Sixty thousand fomilies, were said by Cortez, to be contained 
in the city of Mexico, when he led his band of ruffians against it. From these effects we may determine with certainty, that the defect in the Indian population, was not derived from any weakness, inpotency, degradation, or defect of snttire; but arose from a situation, in which every circumstance was unfriendly to increase, and multiplication.

From the beardless countenance, and inattention of the Indian to the female, some philo. sophers of great cminence and abilities, have formed the most extravagant systems and theories. One has asserted that the Indian of $\mathrm{A}$ merica has an inferior constitution to the European ; that he is weak, and deficient in the organs of generation; without arduur, and impotent with the female; and destitute of natural affections to his wife and children.* Another is positive that he is not descended from the common parents of the whites, but is a distinct, separate, and inferior ordcr of men to them; of a different original, and species. $\uparrow$ And it seems to be generally asserted and believed, by the historians who have quoted these accounts, that the man of America was of less force, energy, and vigour, than the man of Europe; and laboured under some physical defect, or degradation.

THE clearest proof, and the most unexceptionable evidence, ought to have been produced, before a philosopher admitted as facts, things so repugnant to the general principles and laws of naturc. Had this been attempted, it would

M. de Buffon, xviii. 146 .

Kaims' Sketche Hist. of Man, Vol. I. Sketch I. Vol, III, Sketch 12: 
have corrected the error; for the facts are all in opposition, to what has been so often assert: ed, and quoted. No such animal was ever seen in America, as the Indian M. de Buffon described in Paris. If the facts liad been true, the conclusions which have been drawn from them, would have been wholly uncertain. 'The want of a beard would have been no proof, that the Indians were incapable of population : And the want of that excessive licentious ardour; with which the negro and the libertine glows, is in no degree unfriendly to population. Every passion carried to excess; tends to weaken and enervate the whole animal frame. In obedience to that temperance, purity, and regularity, which nature enjoins and requires; are we to look for the effects, which nature designs. But the ardour produced by luxury, intemperance, and excess, weakens its own powers, defeats its end, and destroys its purpose : Instead of proving favourable to population, it tends to weakness, impotency, and the loss of manhood. Is it not surprising, that philosophers who had seen the debilitating and degrading effects, which luxury, intemperance, and excess, are constantly producing in the populous cities of Europe; should view the unnatural ardour they create, in any other; than an unfavourable light? Or suspect the Indian was inferior by nature to the Euro: pean, because he did not appear to be governed by that unnatural ardour, which never fails to debilitate all the powers of nature: And which often ends, in the most emaciated and degraded state, to which man can be reduced ? Happily for himself, the Indian was without this unnatui

VOL. I.

D 2 
ral ardour. Had it been added to the other unfortunate circumstances attending his situation, it would have gone far to have destroyed the whole race.

Averse to aIe Imeproverents. The most fatal circumstance of all, was, the savage statc was extremely averse and opposed to all improvements. It is with a benevolent design, that nature reconciles and conciliates the mind of man, to that state in which it is placed. At the same time, it has made us capable of coninual advance and progression, to greater improvements and perfection. So attached was the savage to the former, that he had no wish or desire of the latter. Content and satisfied with his own state, he had no wish, hope, or conception, that it could be changed for a better. Accustomed to the most perfect freedom and independence, he beheld with detestation, the inequality of rank, and the subordination establisher among the Europeans. Free from all care, and without foresight, he was amazed at the anxiety, the care, and perpetual irrdustry of the white people: And could not conceive why they should be thus perpetually adding hard labour, to the other calamities of life. The constant scenes of hurry, care, and business, in which they were employed, werc objects averse to all their feelings and wishes: And what they viewed as the most degraded condition, to which man could be reduced, was the business of agriculture, digging and labouring in the earth. The weapons of the Europeans appeared useful to them, and these they were at much pains to acquire. But most of their arts, customs, and 
manners, were greatly disagrecable to men, accustomed only to the business of luunting and fighting. Men thus satisfied with their own condition, and averse to that of others, could not be brought, but with great difficulty, to ad. mit the improvements of the civilized life; or to give up that independence, which they esteemed the highest distinction, and the greatest glory of man.

THE appetite for the hunter's state, is one of the most general and powerful, that prevails in any period of society. Men never quit this state, until it becomes inadequate to their sub. sistence and support. It is in hunting and in fishing, not in agriculture and the arts, that the indolent and wealthy in the most polished nations, find their favourite amusement and exercise. The children of the white people, when carried among the savages in early life, have often contracted such an attachment to that state, that they could not be persuaded to return, and reside among their friends. But nothing can reconcile the children of the Indians, to the customs, manners, and methods of living among the Europeans : However caressed and indulged, they droop and languish, until they return to the freedom and wildness of the forest.

Nor was there any thing in the savage state, that could refine or improve itself. While the game continued, the same method of living would have remained : And this would naturally have continued all the disadvantages, and habits of the savage state. The same method of support, would have perpetuated the same manners, maxims, and customs. Nothing 
would have led a people in such a situation, to any improvements, until necessity should have introduced agriculture ; and forced them to be: come husbandmen, instead of remaining hun: ters.

Sucr were the disadvantages attending the savage state. They appear to have been in: separably connected with it : And of such a nature, as to prevent the improvement, progress, or increase of society. We need not hesitate to pronounce, that these disadvantages far exceeded any advantages that could attend it; and operated with a certain and fatal tendency, to continue man in a state of infancy, weakness, and the greatest imperfection. The freedom to which it led, was its greatest blessing; but the independence of which the savage was so fond, was never designed for man: And it is only in the improvements of civil society, that the human race can find the greatest increase of their num: bers, knowledge, safety, and happiness. 


\section{CHAPTER VIII.}

Original Inhabitants. Observations on the Origin of the Indians, their Antiquity, Progress of Sosiety, and Tendency to Dissolution.

THE Man of America differed in so many respects from the men of other countries, that it has been made a question among some of the modern philosophers, whether he was originally derived from the same parents as the white men ; or ought to be considered as a different race, from the men of other countries. No inquiries have the appearance of greater difficulties than those, which relate to the origin, and anitiquity of the American Indians. Without attempting to resolve all the questions that have been proposed upon these subjects, it may be of use to collect some of the facts that seem to relate to them, and to note the conclusions to which they lead.

ORIGIN. In whatever manner this part of the earth was peopled, the Indian or the Red Mian, seems to have been the most ancient, or the original man of America. This race were by far the most numerous; and they had spread over the whole continent, from about the fiftieth degree of north latitude to the southern extremi. ty of Cape Horn. This wast extent of country, including all the variety of climates, was settled with the red men : And these men, every where appeared to be the same race, or kind of people. In every part of the continent, the Indians were 
marked with a similarity of colour, features, and every circumstance of external appearance. Pedro de Cieca de Lcon, who was one of the conquerors of Peru, and had travelled through many provinces of America, gives this account of the inhabitants: "The people, men and women, although there is such a multitude of tribes or nations as to be almost innumerable, and such diversity of climates, appear nevertheJess like the children of one father and mother." Ulloa, an able philosopher, and an accurate observer, visited and observed many of the Indian tribes and nations, of South America : He observed also the Indians at Cape Breton, in North America ; and saith of the latter, that they were the same people with the Indians of Peru, resembling them in complexion, in manners, and in customs; the only visible difierence, being; that the Indians at Cape Breton, were of a larger stature than those at Peru. "If we have seen one Amcrican," saith he, "we may be said to have scen them all, their colour and make are so nearly the same." $\uparrow$ And it is worthy of remark, that no nation or people upon the earth, ever have spread over so large a tract of country, as these red men of America.

WERE these men the same people with the inhabitants of the other parts of the glube? Or did they radically differ fron the men of all other countries? 1. They were of the same complexion, with the most ancient mion in Asia. From authentic clocuments, we are ablic to trace the existence, and national transactions of the

* Erbertson's Hist. America, Vol. Il, p gfz. note dj.

+ Ulica, kotic. Amerienus, 308. 
Hindoos, to an higher antiquity, than we can find with certainty in any other nation. These were the Indians, or red men of Asia. And the Indians of both continents, are marked with the same peculiarity of colour. "The distinguishing colour of the Indian, is red, or rather a reddish brown ; resembling, but more dark than a copper colour. From this similarity of complexion, it is natural to conjecture, that the Indian of Asia and of America belonged to the same family. 2. The features and countenance of the American Indians, very much resembie those of another of the nations of Asia, the Tar. tars. The Tartars join upon India, are spread orer the northern parts of Asia, and extend to the eastern coasts of the Pacific occan. Of thcir appearance and countenance, geographers give us this account: "They are in general strong made, stout men : 'Their faces broad, their noses fattish, their eyes small and black, but very quick." * The Indians of America are thus described, by those who had lived long among them: "The limbs are well turned, the body of just proportion, the countenance broad, their nose flat, their eyes black, small, but capable of discerning objects at a great distance." $†$ If these descriptions had been taken from the same individual, there could not have been a greater agreement, in every circumstance of aspect and countenance.

3. Some information respecting the descent of nations, may also be derived from their customs. Those customs and manners which arise

- Guthrie's Geog. p. 660.

+ Uhoa's and Pinte's aecount. Roberteon's F⿸广stst. Amer. I, 460. 
from the wants, desires, and inclinations, pecisliar to situation and employment, will be the same in the same state of society. A hunter ini Asia, and a hunter in America, will have nearIy the same character, the same occupations, pursuits, and manners. But those customs which do not arise from situation, or from any natural want or desire, may be termed arbitrairy: And the probability is, that two nations would not agree in these, unless they were derived from the one to the other. Several of these arbitrary customs, were common to the men of Asia and America.

$\mathrm{O}_{\mathrm{NE}}$ of these customs, was that of extracting their beards with the rcots. The Tartars and the Americans, had both adopted this practice. Both of them appeared either wholly without a beard, or only with a few scattered hairs : And both of them miade it their practice to extract or pluck them out with the roots. Something of the same kind is practised by the Chinese. The Tartar and the American had both contracted the same wandering or roving disposition, contrary to the customs and dispositions of most nations ; who seldom have any disposition to desert their connexions and country, until they are compelled to it by necessity or force. They had both adopted the same method of war; wasting, destroying, and burning a counitry. The custom of scalping the dead, was one of the barbarous habits the Scythians practised. They cut a circle round the necks of those which they had slain, stripped off the skin, and carried ${ }^{*}$ it with them in triumph. In their marches, the Kamtschatkans never went 


\section{HISTORY OF VERMONT.}

abreast, but followed one another in the form of the Indian file. 'The Tongusi, the most numerous ntion resident in Siberia, use canoes mide of birch bark, distended over ribs of wood, and nicely served together. In these customs they are exactly imitated by the Indians of $\mathrm{A}$. merica. In burying the dead, many of the $A$. merican nations pace the corps at full length, others place it in a sitting posture, and lay by it the most valuable clothing, provision, and arms. The Tartars did the same; and both people ayreed in covering the whole with earth, so as to form a tumulus or barrow. The method, in which both people treated their near. est friends and relations, was still more extra. ordinary and uncommon. When their fathers and nearest friends were become extremely old and infirm, on were seized with a distemper deemed incurable, it was the custom of the Tartars to make a small hut for the patient, near some river, and to supply it with a small quan. tity of provisions: Removing the sufferer to such a situation, they left him to end his days, without visiting or affording him any further relief. 'The rudest tribes of the Americans, in several parts of the continent, had the same custom ; and sometimes they made use of force to extinguish the remains of life, in their diseased and aged friends. Both people adopted this custom, opposite to the practice of all other nations: And they both viewed it in the same. light, not as an act of cruclty, or of any disres. pect; but as a deed of duty, and mercy : And they both assigned the same reason for it: "They were kindly relieving their friends from VOE. I. E 2 


\section{NATURAL AND CIVIL}

the increasing and unavoidable miseries of life ; and they were assisting them in their journey to the other country." "Nor is it to be doubted but that they assigned the true reason and mo. tive, upon which they acted; for no people were ever known to pay a greater reverence to the aged, or were more cntulusiastic in the venera. tion they paid to the tombs and nemories of their ancestors.

SuC E customs are not derived from any nate ural appetite, or from any thing peculiar to the state of the hunter, or the savage; but must be decmed extraordinary, uncominon, and arbitra. ry. Being fond only among the men of Asia and America, the presimption is, that they were derived from the one to the other; or that the latter had taken then from the former.

4. In the empire of Peru, there were several appearances of Chinese customs and manners. The appearance, the dress, and the superior knowledge, of Manco Capac and Mama Ocollo; the knowledge of agriculiure and the arts, in which the one instructed the men : the knowl. edge of spinning, knitting; weaving, and making garments of cotton, which the other diffused among the women; the high estimation which the children of the sun assigned to agriculture. above all other arts and professions; their custom of tilling a field with their own hands; the ceremony with which the Inca began the business in the spring; the festivals which attended it; the unlimited authority of the emperor, with the patriarchal aspect of the government; the benevolent tendency of their laws, and wars; and their public regulations respecting roads, 
bridges, canals, industry, provision for the poor and aged, and the responsibility of parents for the conduct of their children; all, or most of these articles, bore a greater resemblance to Chinese maxims, manners, and customs, than could have been acquired in America, during the life of one man and woman, from their orin observations and reasonings. They were advances towards a state of civilization, that no. thing in the degraded state of the Pcruvians, could have sugrested, or produced, but in a long period of time.

IVI CH pains has been taken by many learned and ingenious men, to compare the languages of the Americans, with those of other nations. But while these inquirics have been carried on with great assiduity, the most ancicnt language which prevailed in the east, the Sanskreet, "the parent of almost every dialect from the Persian gulf to the Cinina seas," "** was itself wholly unknown: And no information has been derived from these inquiries.

We must reison then from such circumstanees as we can find: And if a judgment can be formed from a similarity of complexion, fea. tures, and customs, we shail be led to conclude that the men of America were the same people with the men of Asia; but that their descent, was not from any particular one, but from several nations on the eastern continent.

No difficulty could ever have attended such emigrations. The continents of Asia and A. merica approach so near to each other, that the

* Preface to the Grammar of the Benga? Language, p. 3. The Era: sandation fom the bansk reet langurge was publighed in 1785. 
Inhabitants are frequently passing from the one to the other. The discovcries of the Russians, and the greater discoveries of the most celebra. ted modern navigator, Captain Cook, have made it certain that if the two continents are seferdted at all, it is only by a strait, not more than eighteen miles in width. At no time within the period of history, was the navigation of the rudest tribes unequal to the passage of such a strait. And probably there never has been any difficulty, in passing from the one continent to the other.

IT is not improbable that the red men of Asia, might find a passage into America alto. gether by navigation. "It has been long known that the Asiatic nation called the Malayans, possessed in former times, much the largest part of the trade of the Indies; and that their ships freguented, not only all the coasts of Asia, but even those of Atrica, and particularly the large island of Madagascar. It has been more lately discovered, that the same nation had extunded their voyages and migrations from Mudagascar, to the Marquesas, and Easter Island; that is nearly from the east side of Africa, until we approach the west coast of America. This space includes almost one haif of the circumference of the globe. Thro' this immense space the Mallyans had spread, made settlements, and founded colonies in the islands at all the inter mediate stages, at an immonse distance from the parent continent. The royages of Captain Cook have afforded the proof of these listorical facts: And they have been ascertained not only by a similarity of 
manners and customs, but by the affinity of language, and a collection of similar words, made from all the widely diffused islands and countries visited by this celebrated navigutor."

A PEOPLE who had thus spread over ono half of the globe, from the coast of Africa to. wards America, and who had settled all the isl. ands that lay between them, could scarcely have avoided arriving upon the western coist of America, and leaving some of her people there. Several of the islands that were settled, were near the American coast; and it must have been much easier to have discovered the continent along the western coast of Anicrica, than to have found so many small and scattered islands. It is therefore highly probable, that the same people who spread over the islands in the Pacific ocean, should at times arrive also on the western shores of the continent. In both these ways might people from different nations in Asia, find a passage into America, and at very different periods of time.

The Indians however, were not the only men which appeared in America. Another race or kind of men were settled in the northern pists of the continent. These have been calied $E_{s}$. quimaux. In their colour, dimensions, festures, and customs, they differed much from the red men. They were of a fullow or brownish com. plexion: Their size about four feet in height : their faces long and wrinkled; their noses thick and compressed; their eyes small and sunk; their cheeks much raised; their eyebrows and eyelids thick; with sniall Icgs wisct hands. This nation had spread over the most northera 
parts of America. They are found in Green. land, on the coast of Labradore, in Hudson's bay, and in ail the coasts and islands on the west side of America, opposite to Kamtschatka. Their migrations had extended to Norton's sound, Onolashka, and prince William's sound; one thousand five hundred leagues from their stations, in Greenland and Labradore. The sameness of the people in these different piaces, has been ascertained by their manners, customs, features, and complexion; but more decidedly by such an affinity and similarity of languagge, as leaves no room for doubt. It will be eisy to determine from whence this nation of the Esquimars proceeded. Every thing in the appearance of this people, denotes them to be the same with the Laplanders, the Zemblans, the Samojeds, and the Tartars in the east.... Like them they are a nation of dwaris; largest towards the south, but decreasing towards the north. They have all the same fallow complex. ion, deformed fectures, ugly appearance, and singular customs. Whether the inhabitants, could pass from the northern parts of Europe into America by land is as yet unknown. But the passage by water, was at all times casy ; and certainly at a very early period. In the voyage from Norway to Iceland, and from Iceland to Greenland, or the coast of Labradore, the first part of the voyage was much the largest: And this was practised from the earliest times, of which we have any account. For the ninth century, when navigation was extremely imperfect, the passage from Europe to America was go well understood, that the Norryegians planted 


\section{HISTORY OF VERMONT. 235}

and settled their colonies in Greenland. There is but little room then to doubt but that the na. tion of the Esquimaux was derived from the same people in the northwest parts of Europe. Their descent therefore must have been from the Tartars of Asia, for it was from them, that the Laplanders, who are spread over the north. western parts of Europe, irere derived. In the year 1769, Pere Hall, an astronomer of Hungary, was sent into Lapland to observe the transit of Venus. This able philosopher hada good oppor. tunity to become acquainted with the manners, customs, features, and language of the inhabitants in that part of the globe : By his account, " it appears that the Laplanders are only degen. erate Tartars; and that they, and the Hungarians, originally sprung from the sime breed of men, and from the same country."

The tiwo kinds of men then that were in America were derived from the same source. The Indians and the Esquimaux, were both descended from the man of Asia; and probably the most of them, from the same nation, the Tartars. In America then nature had not made different races of men, fitted for, and originally placed in different climates. The men of America were the same with the men of Asia: And both of them migrated from one place to another, and spread through all the various climates of the earth. They were distinguished by the differ. ences of complexion, dimension, features, arbitrary customs, and peculiarities of manners; as much as the inhabitants are in other parts of the

- Kaim' Sketches of the Hist. of Man, I. P. II. 
globe. But these differences must have been derived from qlimatc, food, manner of living, or some other circumstance ; for they certainly were not derived from a different origin, or any particular local creation.

The constitution of man appears to be the same, in every part of the globe. Nature has given to him the same physical and moral pow. ers, capable of different degrees of improvement according to the state of society in which he shall be placed. But in no country, or part of the globe, does min arpear to be an animal of climate. Among animals nothing is more ap. parent, than that some are animals of climate; that is, they are fitted by nature and constitution to some particular part of the globe; where a. Ione they can subsist, multiply, and obtain their proper perfection. 'Thus the animals peculiar to the torid and frigid zone, never leave their particular climates out of choice; and when a change of climate is forced upon them, they degenerate, and waste away. It is evident that man is not such an animal. He can multiply, and attain his proper perfection in all the various climates of the earth. Nature has not furnished him with any kind of covering, fitted to a hot, to a temperate, or to a cold climate : This is left to his orvn reason and industry, according as his situation may require. Nor has nature assigned to him any particular, invariable colour. Black is the absence or want, and white is the mixture of all colours: And these are the extremes between which, all the various complexions fall: Nature therefore has not as= signed to man any covering, or any invariable 
colour, or any thing in his constitution, that has fitted him particularly for the torrid, temperate, or frigid zone : But has given him a nature and constitution, adapted to cvery clinate. And in every climate which produces his proper food, the white, the red, and the black men, will subsist, multiply, and attain their proper perfection. If nature has thus made man the animal of all climates, would it not be altogether umphilosophical, to look out for local creations ; or to introduce miraculous interpositions of the Deity, to explain those differences among men in other places, which in America, we are certain were derived from natural causes?

ANTIQUITY. In attempting to estimate the antiquity of the most polished nations, we can derive but little information from history. No records, no monuments, no writings can be found, that reach back to so ancient a period. Least of all is this to be expected from a race of savages, which had not the knowledge of letters. All the information we can obtain, must be derived from such circumstances and events, as imply or denote certain periods of years; and of these there are but few, in the transactions of the savage state.

Some information may be collected from the extent of the country they had settled. The continent of America, in its dimensions, amounts to one third part of the habitable globe. Over the whole of this continent had the savages ex. tended, when it was first discovered by Columbus, in the year 1492. Their population had

* Anpendix No. V.

HoI. I. F 2 
then attained its greatest perfection. No in: crease of their numbers has any where appeared to take place, since that time. No circumstance. or event has taken place during the three hundred years, that the Europeans have been acquainted with the Indians, which can lead us to suspect that the savage state either has, or can adnit of a greater population, than what it had already attained. Nor is it probable, that any increase of numbers, and population, could have taken place, while hunting continued to be the method of procuring subsistence. From the observations that were made in Virginia, and Massachusetts, it has been computed that the population of the Indians upon the sea coasts, could not be estimated higher than one for every square mile. In the inland parts of the country, the Indian population certainly did not ex. ceed this. Geographers have computed the number of square miles in America, to amount to fourteen millions, one hundred and ten thousand, eight hundred and seventy four. We can. not make a nearer computation, than to suppose this was about the number of Indians it required in the hunter's state, to spread over the whole continent. How long a period would it require, for the savages to increase to such a number? There has been no instance of a more rapid increase, than that of the British colonies in America. 'They were aided by new emigrations from Europe: But so much were they retarded and broke up in their settlements by war, before the American revolution, that they did not in fact double their numbers in thirt years. The families of the Indians did not 


\section{HISTORY OF VERMONT. 239}

contain more than haif so many members, as those of the white people. The Indian population then will be highly estimated, if we compute it to be one half of that of the white inhabi. itants ; and instead of thirty, admit sixty years as the period of doubling. Assuming the population to have proceeded from one male and female, this would require thirtcen centuries and an half to have spread over the whole continent, and produced one inhabitant to every square mile. The period of population could not have been less than this. But probably this period was completed long before Columbus came into America. The Indians in several places, had gone out of the hunter's state. On the sea coasts they were advancing into something like monarchy. In Mexico and Peru they were be. come extremely numerous, and had established extensive and powerful empires; the duration of which, could be traced back four or five hundred years. From their extent and population then, we deduce with some degree of probability, that the Indians must have been settled in America eighteen centuries when Columbus first discovered the continent. This will carry us back three centuries before the christian era.

Tнв number and variety of their languages implies and requires a much longer duration, and an higher antiquity. The Indians of A. merica had not only spread over the continent, but they had every where formed themselves into a number of small tribes. If we may judge of the number of these tribes from what took place in New England, and Virginia, they must have amounted to thousands. Several of thes? 
tribes had subsisted so long in a national form, and as a distinct people, that they had formed? a particular language for themselves. There were three original languages spoken in Canada; the Sioux, the Huron, and the Algonquin. In New England, there were one or two others.t In Virginia there were threc, different from cither of these.f In Mexico thirty five were discovered. In South America there were still more. In Maraguon, the Portuguese counted fifty. In cach of these places, the dialects were nearly as manj as their tribes. And yet these places made but a small part of the continent. What an immense period of time does this require? A language may be separated into different dialects in a few generations : But for these dialects to recede so far from one another, as to lose all resemblance and aftinity ; and sereral new languages to be formed, radically differing from one another; such an event could not take place, or be effected, lintil the tribes had subsisted for inany centuries, as distinct and separate nations. We cannot cstimate this process by fixed periods of time, because we have no facts from which a computation can be made. But it may be compared to the state and progress of things, in the other hemisphere: and we shall find the number of languages radically differing from one another, more numerous among the Americans, than they were in Asia and Europe. Is not this an indication, that the red nen of America are as ancient as the other nations of the carth?

* Abbe Raynal, V. IO:.

+ Hutchinson, $1.457,479$.

I Jeflerson's Notcs on Virginia, p. 99.

Clavigero's Hist. of Mexico. 


\section{HISTORY OF VERMONT. 241}

Learning and science they had none: But nature, situation, and necessity, would opcrate as certainly, and, as regularly upon them, as upon any other peopie. And would it not require as long a period of time to produce, and to form a language among the savages, as among any other people? This circumstance seems to denote an antiquity, fully equal to that, which is claimed by any of the nations of the other hemisphere.

THEIR antiquity may also be traced back to the time, when the most useful arts wore unknown; and when the red men of Asia had not the use of the metals, or of domestic animals. Some of the arts must have been nearly cocval with the human race; for neither food, raiment, or habitations, could be procured without something of them. Other of the arts have been gradually advancing, without orving much to any original inventor. And many of rem are of such antiquity, that their origin and inventor are beyond the reach of history. This is the case with the most necessary and useful arts of life. The origin of spinning, and knitting, of the plough, the loom, and the forge, were more ancient than any of our historical monuments, records, or traditions. But when those arts were invented, they never could be lost. Amidst the wars, changes, and revolutions, to which nations are exposed, what are called the fine arts may perish and be lost. But no vicissitudes of human affairs tend to dicstroy those arts, by which ail men derive their subsistence; and which are equally necessary to the conqueror and to the captive, to the oppressor and to 
the oppressed. The same observation may be made with respect to the use of clomestic animals. A people that have experienced the advantages derived from the food they afford, and from the labour they perform, would never lose this kind of knowledge; but endearour to apply it to such kind of animals, as they found in the country to which they repaired. Of all these, the Indians of America were ignorant. They knew not the use of the metals, spinning, weaving, or the domestic animals : They had derived no such knowledge from their ancestors, nor had they acquired it themselves. At what period then, must they have settled in America? Before these arts were known in Asia. Before the Scythians became husbandmen, and before the most necessary and useful arts were known in the midst of Asia. Without attempting therefore to go back to the beginning of the creation of God, we can find circumstances that will carry us as far back into antiquity, as any other nation can pretend. The history and pretensions of the Chinese, do not imply or suppose any circumstances of greater antiquity, than those which have been mentioned. And it must be from circumstances and facts, not from tradition, that we must trace the antiquity and origin of ancient nations.

Progress of Societr. The progress of society among the Indians, would make a curious, and most useful part of their history. The rudest and most simple state that took place among them, was that which I have bcen describing. Wheresocver the savages continued to derive their support from hunting, they con- 


\section{HISTORY OF VERMONT.}

tinued from age to age in the same condition, and made no improvements. Where the means of subsistence were plentiful, and easy to be procured, the Indians had advanced beyond the state of an hunter, and began to increase their numbers, and their agriculture. In such places, society began to assume a different form, from what it bore in their rudest and most simple state. And the tendency of it was every where to monarchy. In the southern parts of New England, and Virginia, some of the tribes were advancing fast to the form of hereditary monarchy. In the hotter climates it was already established. This was the case in Florida, among the Natchez on the Missisippi, in Cuba, Hispaniola, and all the large islands. In Bagota, Mexico, and Pcru, monarchy had acquired its perfect form, its full powers, and a complete establishment. In each of these places, the progress of government had been from perfect freedom and independence, to almost absolute and unlimited monarchy. In the course of this progress, two remarkable, phenomena appeared ; In one part of America, an empire and a monarchy was established, in most respects resembling those which had arisen in the other hemisphere. In another part of America, an empire and a monarchy was produced, far superior to those which were produced in the other parts of the globe.

In the empire of Mexico, almost every thing had taken the Asiatic, and European course. The great body of the people were reduced to a degraded and humiliating state ; and held their lives, and performed their labours, under various 
names and degrees of degradation and abase ment. A body of nobility were possessed of ample territories, of great privileges, powers, and honours, whder different names and degrees. Above, and over all, was the monarch, enjoying supreme power and dignity. After being elee. tive during the reign of eleven of their sovereigns, the monarchy was become almost absolute and hereditary, in Montezuma. "The sys. tem of religion agreed perfectly well to the nature of the government: It was severe, cruel, and barbarous; and delighted in the sprinkling and shedding of blond: Human sacrifices of all others were esteemed the most acceptable, and availing; and the priests had the privilege, the honour, and the pront, of announcing or removing the vengeance of the gods. This system of monarchy had acquired a stability, a regularity, and a vigcur, equal to any monarchy that was then upon the earth. Upon comparing the spirit of monarchy, untempered by representation, in America, in Asia, and in Europe; the spirit and the principles of it, will be found every where to have operated alike. It degrades the body of the people below the condition and nature of man. It exalts the nobles and the sovereign above the condition and state, which nature designs or admits. In one form or another it has always been attended with a persecuting, cruel; and bloody relighion, put into the Finds of a wealthy, and powerful priesthood. It has constantly produced the spirit of war and destruction; and generaly derived to itself security, wealth, and power, from the misery, destruction, and slaughter, it has entailcd on the 
human race. By placing the rulers in a situa. tion altogether unnatural, that is, above all sense of accountability to their fellow men, it has pro. duced that constant, steady, and universal abuse of poiver, which, in every part of the globe, has been the distinguishing and certain effect of this form of government. Its spirit and prin. ciple have every where been the same; not the honour which the great Montesquieu wished to ascribe to it, and wanted to find in it, but that total want of regard and accountability to man, which, with great accuracy and propriety, has been lately named a contempt of the people.

Th $\mathrm{z}$ empire of Peru was forned and govern. ed by a species of monarchy, different from what has ever taken place among any other people. Twelve successive monarchs, for a period' of more than four hundred years, had been invested with hereditary and absolute power. They claimed this authority, not as tlerived to them in any manner or degree from the people, but as the absolute and exclusive donation of heaven. They announced themselves to be the children of the sun, and clothed with divine and unlimited power to direct all the civil and religious affairs of the people. The sovereign was named Inca; and so sacred and pure were the family of the Inca's, in the minds. of the people, that they were universally esteem. ed incapable of committing a crime, or falling into an errour : No other family might marry or mingle with it, for fear of polluting the heav. enly blood. The people looked up to them, as to beings of a superior and heavenly race : And all disobedience to them, was yiewed not barely

VOL. I.

G 2 


\section{NATURAL AND CIVIL}

as a crime committed against men, but as an act of rebellion against God. The nobility of course was nothing more than families of office. Though a difference of rank had taken place throughout the empire, all but the children of the sun, were supposed to belong to the com. mon race of men. The people were well clothed, and fed; every where distinguished for their industry, economy, moderation, contentment, and happiness. Over this people, the Incas, though absolute in porver, established a government the most mild and gentle, that has ever taken place in any part of the earth. The morals of the people were so pure, that ferr crimes were ever committed: The genius of the government was so mild, that few punishments were ever executed: And when they were, they were viewed as the necessary acts of God, and not of men. Their government, the dominion of prosperity and virtue, was esteem. ed by the people the dominion of God and his Inca. 'Their system of religion, like their government, was mild, gentle, and pacific. The sun, the emblem of light, serenity, fertility, beneficence, joy, and life, was the object of their adoration. They offered to him a part of those productions, which they derived from cultivating the earth, enriched by his genial warmth. They presented to him specimens of those works of ingenuity, which they had per. formed by his light. And they brought to him some of those animals, which were nourished by his influence. But the Inca never stained their altars with human blood; or admitted the savage idea, that the source of beneficence could 
be pleased with the persecution, cruelty, and destruction of men. Their system of war partook of the same spirit of mildness, and wisdom. They fought not to exterminate, but to conquer : they conquered not to enslave, but to improve, to civilize, and refine. No cruel tor. ture awaited the captive. No barbarous marks of degradation, disgrace, triumph, or slavery, were reserved for the prisoners. They were taught the same system of grovernment and re. ligion, as the rest of the people : they were admitted to the same privileges; and treated with the same lenity and milaness. Of all the triumphs of the Inca, the noblest and the greatest, was to diffuse the manifold blessings of peace and happiness, to the people whom they had subdued:

Such was the genius, the spirit, and the ef: fect, of the system of monarchy that was estab. lished in Peru. We need not hesitate to pronounce it superior to any, that was then to be found upon the face of the earth. The genius and the spirit of it, were above all others, mild and gentle : the object and the aim of it, were in fact, the improvement and the happiness of the people. And if any government ever produced this effect, that government was the monarchy of Peru : Not the attainment of the most polislied nations of Asia, and Europe: of their arts, science, and improvement; but of the greater wisdom and simplicity of the Indians, and Incas of America.

$W_{E}$ have here a phenomenon, new, and al: most incredible in the political world. Abso* Iute, unimited, and hereditary nonarchy, whicit. 
has never failed before or since to prove one of the heaviest curses, which has fallen upon mankind ; in Peru became mild, gentle, and beneficent : And was constantly employed during the reign of twelve successive monarchs, to refine, civilize, and improve the people; and to do the greatest good to mankind. And yet this was a system not fornded in truth, or in nature; but in delusion and superstition. What could give it a direction so steady, unitorm, and benevolent? Not the form, but the principle of it. It contained the best and the purest principle, that can enter into the nature of human government. Its origin, duration, and power, depended whol- Iy upon the public sentiment. "The Inca claimed immediate descent, and relation to the sun. The sun was the emblem of peace, and benevo. lence. Had the monarch stained his character by enormity in crimes and vices, or by a constant abuse of power, nature would have taught the Peruvians that monsters in corruption, vice, and cruelty, could not have been the favourite children of the Deity. If the Inca had been viewed in this light, all his divinity, and his power would have ended. His porver was founded altogether in the opinion the people had formed of his divine descent, qualifications, character, and virtues. So solicitous had the Incas been to preserve this opinion, that through the whole period of their successions, they had taken the most scrupulous care not to endanger or oppose it, by any base and unworthy conduct. And while they thus proved the constant friends and benefactors of the people, the public esteem and veneration increased. In the benevolence 


\section{HISTORY OF VERMONT.}

and usefulness of the Inca, the people believed they saw the children of the sun: And in the affections and opinions of the people, the Inca found an absolute and unlimited power. But if his conduct had plainly discovered that instead of being the child of the sun, he was the child of folly, of vice, and abominable iniquity, his divinity, his power, and his empire would have ceased with the public opinion.

INSTEAD then of being founded in a contempt of the people like the empire of Mexico, the monarchy of Peru had the singular good fortune of being founded in the public sentiment. This rendered the Inca accountable to the people for every part of his conduct : And this sense of accountability would keep a constant sense of duty and character upon his mind. 'Thus under the form of absolute hereditary monarchy; the government of Peru had the uncommon advantage of excluding nobility with all its odious distinctions and claims; and of embracing the best and purest principles, upon which civil government can ever be founded. The Indians seem to have been the only people, among whom, a regard to the public sentiment and benefit, did in fact constitute the spirit and principle of hereditary and absolute monarchy.

Tendency to Dissolution. However beautiful and promising the progress of socicty once was among the Indians of America, it is now every where tending to decay and dissolution; and this has been its tendency, ever since the first arrival of the Europcars. In the destruction of the empires of Mexico, and Peru, 


\section{NATURAL AND CIVIL}

Cortez and Pizarro performed the most aceurs. ed transactions that ever were done by man. And wherever the Europeans have settled, misery, calamity, and destruction, have been entailed on that unhappy race of men. The vices we have taught them, the diseases we have spread among them, the intemperance they have learnt of us, and the destruction of their game, are evils for which the savage is unable to find a remedy. A contempt of our morals, a horrour at the knavery that has attended our commerce with them, and the constant advances we have made into their country, have filled their minds with prejudices agaimst our arts and improvements. This, added to the frequency and bitterness of their wars, to their constant hardships and sufferings, and to a defective population, but too plainly denote the event. 'The constant waste and decay of this people, must end in their total destruction : According to the pre. sent course and tendency of things, in two or three centuries, the whole race must become. extinct. Instead of wishing for such an event, it would add to the glory of the United States. to make a serious attempt to prevent it. It has been the practice of arbitrary gorernments to sport with the liberties, and lives of men. A government of reason and nature, ought to attempt to conciliate the affections of a free, brave. independent, and generous people. It would be a greater glory than we have ever yet attained, if we could find out a way to impart the bles. sings of the civil state, to a people whose great. est miseries and misfortunes have been derived from the superior arts, the policy, and the porra er of civilized nations. 


\section{CHAPTER IX.}

First Settlements and Wars with the IN DIANS. Earliest accounts of the Northern Indians. Discoveries and settlements in their country by the French. Origin and prugress of War between the natives and the Europeans. Influence of the Priests. French $E x-$ peditions. Proceedings of the Governor of Neruyork. Destruction of Montreal by the Iroquoise. From the year 1535 to 1689.

SUCH were the men who were spread over the northern parts of America in the fifteenth century. It does not appear that any other men but the Indians had ever been in the country, previous to that time. On October the 12th, 1492, by astonishing efforts of genius and perseverance, Columbus, discovered the western hernisphere, at the island of Guanahana. Among all his discoveries the most important, was that of a new race of men; of men in their appearance, manners, habits, and customs, very different from the inhabitants of the eastern hemisphere. Influenced by the spirit of curiosity, enterprize, avarice, and ambition, the subjects of the Spanish monarchy embarked in great numbers to the southern parts of Ameri$\mathrm{ca}$; visited the natives, subdued the accessable parts of their country, and planted them with the men of Europe. These attempts and measures every where produced the same effects, bloody and barbarous wars, between the men of the two continents; now for the first time, in? 
termixing and mingling together.

WhIL the court of Spain was carrying its conquests, and advancing its interest in the southern parts of America, the courts of France and England turned their attention to the northern parts of the continent; and endeavored in those regions to find avenues equally favorable to commerce, conquest, wealth, and power. Francis the first, at that time king of France, was one of the most active princes of the age ; and though constantly involved in wars and misfortunes he did not intend that the kings of Spain and England should divide the whole continent of America between themselves. With a view to explore the northern latitudes; and to find a place for a French colony, he fitted out James. Cartier on a voyage of discovery. Cartier sailed from St. Malo, on the 20th of April 1534; and in the course of the summer entered the mouth of Canada rives visited the bay of Chaleur, and that of Gaspe ; and from thence sailed to the northward, till he discover. ed the land on the opposite side of the river. Having made these discoveries he returned to France, and arrived at St. Malo on the fifth of September.

THE next year he was fitted out with three ships, and arrived at the isle of Orleans, in the beginning of September, and came to anchor between the island and the north shore. To the river he gave the name of St. Lawrence; and leaving his ships at anchor on September the 19th, he set out with his pinnace and two boats upon a voyage up the river to Hochelaga ; where he arrived October the second, and gave to the 
place the name of Montreal, by which it has ev. er since been denoted.

INST $A \mathrm{D}$ of meeting with hostilities at either place, Cartier was received by the natives with all the demonstrations of joy, which they were able to exhibit. At Hochelaga the Indians had intelligence of his approach, and made prepara. tions to give him the most friendly reception. The savages, to the number of about a thou. sand, came forward in a body to bid him wel. come to their country. The men were on one side, the women on the other, and the children in a body by themselves; and the whole came forward singing and dancing, with every ap. pearance of the highest confidence and joy. To their new guests, the Indians made presents of corn, fish, and such other kind of provisions as they had ; in return, the Frenchmen gave knives, beads, and other trinkets. The first night the Europeans lodged in their boats, and the natives watched on the shore, dancing all night round their fires.

THE next day Cartier with twenty five of his company set out on a visit to the Indian town. He was met on his way by a man, who appear. ed to be one of their chiefs; and whose business it was, to introduce him to the capital of their country. Cartier presented to the Indian chief two hatchets, two knives, and a cross, which he hung over the Indians neck, and taught him to kiss. Passing from the river towards the town; the French went through groves of oak, the acorns of which were fallen, and were so nume. rous as to cover the ground. They passed also through fields of $\operatorname{corn}_{8}$ some of it gathered. จ०ะ. B. H 2 
and all ripe. In the midst of these fields of $\mathrm{Corri}_{\text {; }}$ and surrounded by them, was the Indian capio tal, Hochelaga.

THE construction and state of the town dis. covered a degree of improvement, of which Cartice had before met with no specimen in the Indian country, and had no expectation to find from the Indian genius. It was laid out in a circular form, and was surrounded with three lines of palisadoes; through these palisades there was but one passage or place of entrance, and that was well secured both with stakes and bars. On the inside, the fortification consisted of what in the European language was called a rampart of timber, to which the ascent was by ladders: heaps of stones were also collected, and placed in such situations as would best serve the pur. poses of strength or defence. Within these fortifications there were about fifty Indian hous. es: these houses were a kind of long huts, built with stakes, and covered with the bark of trees. In the midule of each Indian house there was a fire place; and around the sides were the lodging or sleeping places, the floors of which. were bark, and the covering made of skins. In the upper parts of the houses were scaffolds, on which they placed and ciried their corn. Their provisions were corn, beans, squashes, pumpkins, and fish. Their corn they pounded in a. kind of wooken mortars, and when beat mixed with water, and-baked on hot stones. Their fish was dried in the sun, or in their houses, and preserved in troughs. Their squashes and pumpkins were generally consumed while they remained green. At Hochelaga the people ape 


\section{HISTORY OF VERMONT. 255}

peared to derive their chief subsistence from fishing and tillage, but in the lower parts of the river, hunting seemed to be the chief employment : But at both places, the sachem, or chief man of Hochelaga was considered as the sovereign, to whom the people were in subjection, and paid tribute.

IN the centre of the town there was a large open square : to that place Cartier and his company was conducted, and mats were spread on the ground for the new guests to sit on. The Indian men seated themselves in a large circle round them; but the women came weeping, with joy, rubbing their hands and faces, and bringing their children to be touched by their new visitors. At length the sovereign, the Indian King, was brought on the shoulders of ten men, and placed on a mat next to Cartier. The monarch of the savages had a covering made of the quills of the porcupine, died red ; this he took off and gave to the French captain, requesting him at the same time to rub his arms and legs, which were much affected with a palsy. Scveral other persons declining with age or sickness, were also brought to be touched and healed by the strangers. Cartier saw at once that the Indians viewed him and his company as gods ; or at least as a race of beings far su. perior to themselves; and resolved to avail himself of their weakness and superstition. He laid his hands on them, cast his eyes to heaven, repeated some devotional passages from his service book, and assumed such features and gestures as he supposed would most engage and affect a savage mind and tribe. The Indians 
attentively observed all his motions and ges: tures, and endeavored to imitate and repeat them.

TuIs farce being finished, Cartier proceeded to exhibit more substantial proofs of his benevo. lence and power. He signified to the multi: tude that he wished the men, women, and chil. dren, would divide themselves into separate companies. The natives immediately made such an arrangement. To the men Cartier then made a present of hatchets, to the women he presented a quantity of beads, and to the children he gave a multitude of rings. The moment these donations were ended, he ordered his frums to beat, and the trumpets to sound. As. lonished but delighted with the scene the sava. ges shouted, and the whole company fell to dancing. What could be wanting to convince he multitude that their new guests werc gods, ull of benevolence and power?

CARTIER next proposed to ascend the hill, inder which the town was built. The Indians conducted hina to the summit, and pointed out to him the course of the river above their town: and informed him that he might sail on it for three moons without coming to an end : that it ran through two or three lakes; that beyond them there was a sea of fresh water, to which they knew of no limits; that on the other side of the mountains there was another river which ran to the southwest, through a country in which there was no ice or snow; and that there. were such metals as silver, gold, and copper, to. be found in the country. Having obtained alk the information which he expected, Cartier pre. 
pared to depart, and left Hochelaga October the fourth. 'The natives accompanied the French to their boats, carried such of them as were sick upon their shoulders, and followed them along the banks of the river to a considerable distance : discovering the marks of sorrow and distress at their departure. On October the eleventh Cartier and his company arrived safe at the isle of Orleans, where he tarried that winter, and attempted to found a colony, but which was soon broke up.

From this voyage, the first that had ever been made into the interior parts of North A. merica, the manners and dispositions of the na. tives became in some measure known. It was found that the Indians were divided into many distinct tribes or nations; which, instead of being in a state of union or confederation among themselves, were generally in a state of hostility and war. Among other proofs of their hostility to each other, Cartier found at the isle of Or. leans the scalps of five men, spread out, and dried like parchment. These, he was told were taken from some of the southern Indians, with whom they were constantly at variance; and that the scalps of their enemies were considered as the most honorable evidence of their own prowess and exploits in war. But with respect to their new visitors, instead of any appearances of suspicion, fear, or hostility, they were every where received with the tokens of friendship. confidence, and the highest expectations of un. common benefit and advantage from their visitations. Instead of making any preparations to oppose, the natives received them with the high. 
est marks and effusions of joy, as beings of a superior order, from whose benevolence and power they expected to receive uncommon benefits and advantages. Nor was it till the Europcans began their enterprizes of 'injustice and violence that the natives had any fear or suspicion, or made any preparations either for: defence or hostility: *

THE colony attempted by Cartier having failed, no further attempt was made either to. explore, or to make any settlements in the interior parts of Canada, till the year 1603. That year a voyage was undertaken by SAMUEL. CHAKRAIN, a man of a noble family in France. He sailed up the river St. Lawrence as far as Cartier had proceeded in 1535, and risited the places which that celebrated navigator had de. scribed. Passing the isle of Orleans he came to anchor at a place called Quebec, which in the language of the natives denoted a strait. Champlain remarked that this place might be approached by the largest vessels, that it was surrounded by water on three of its sides, had a situation clevated and commanding ; and that with a little labor it might be made a place of swreat strength, and was in cvery view a fit place io erect a fort, and besgin a sctilement. He then procecded up the river to Hochelaga or Jivontreal, and made many inquiries of the na. tives respecting their country, its rivers, lakes, productions, and inhabitants. Without fear or suspicion, and with the most artless simplicity, the Indians informed him that there was a com-

* Haxhluyt Val. 3, 20I-209. Amcrican Biography Vol. 1, paga $258-18 \div$ 
munication to the south, by means of the lake: with a fertile country, which belonged to a powerful and warlike nation called the Iroquoise: that there were several and large lakes to the west, to one of which they knew of no bounds ; and that to the north there was a large inland sea of salt water, the limits of which were also unknown. Kaving obtained this information, Champlain returned to France to communicate his discoveries to the government; and to procure assistance and supplies, to effect a settlement in the country.

Is 1607 the establishment of a colony on the river St. Lawrence, became an object of serious attention to the court and merchants of France. It was concluded that such a colony would extend the fur trade, and open a communication to China through the western lakes; and thus serve to benefit the kingdom, and to enrich the adventurers. Encouraged by these expectations, several vessels were fitted out in the year 1608, to begin a colony. Champlain had the command. He arrived at the place called Quebec, in the beginning of July. In his former voyage he had fixed upon this, as the most eligible place for a settlement, and upon his arrival he immediately began to cut down the trees, to clear up the land, to erect buildings, and pre. pare the soil for gardens and fields. At that place he spent the winter with his company, in the course of which they suffered much from the severity of the climate, and the prevalency of the scurvy.

HAVING began his colony at Quebec, in the spring of the year 1609 Champlain set out to 


\section{NATURAL AND CIVIL}

explore the southern lake, which the Indian informed him opened a communication with the warlike nation of the Iroquoise. Taking with him a party of the natives, and two Frenchmen, he went up the river now called Sorel, and ex. plored both the southern lakes. To the largest of these he gave his own name, Champlain, by which it is still known. To the other he gave the name St. Sacrament, but which has since been called Lake George. On the shure of the latter, Champlain with his company was dis. covered by a party of the Iroquoise. Between these Indians and those at Hochelaga, a war had long subsisted, and a skirmish now took place. The Frenchmen were armed with musquets, and Champlain killed two of the Iroquoise him. self, with that weapon. This was probably the first time the Iroquoise had ever seen the effect of the European arms, and the victory over then seems to have been compleat. The whole party were put to flight, and the scalps of fifty of them were taken and carried in triumph to Quebec.

Is the fall Champlain returned to France, and came again to Quebec in 1610; but so slow was the progress of his colony that it was not till 1626 that Quebec began to assume the appearance of a city, or had any other fortifica. tions than those of wood. That year the for. tress was rebuilt of stone; and preparations were made to defend the place not only against the natives, but lest some of the European ves. sels should approach, and attempt to carry the works. Nor were the preparations needless : A war had broken out between Charles I. king of 
England, and Lewis XIII. king of France ; and as the E'glish were carrying on their settlements with great appearance of success in Vir. ginia and Missachusetts, it was proposed in the English cabinet, to attack the French settlements in North America. In 1629 an armament was fitted out in England for this purpose, and the command given to Sir David Kirk. He sailed up the river St. Lawrence and appeared witt his ships before Quebec. The city was in no con. dition to resist his force, and Champlain was obliged to capitulate. Agreeably to the articles of capitulation, Champlain was sent to France in an English vessel. If he was mortified by the capitulation, he was more mortified by finding that his new colony was an object of but little consideration in France; and that the loss of it was scarcely regretted.

MANY thought it was not worth retaining, that it had already been attended with an expence far above its value, and prob: B.y the case would be the same in future. Others were of opinion that the fur trade and fishery were national objects of real consequence, and that the settlement of Canada was the sure method of increasing their importance, and would serve as a nursery for seamen, and thus eventually prove highly beneficial to navigation and commerce. The councils of Lewis XIII. were so little ac. quainted with the advantages arising from colonies; or with the value of their settlements in Canada, that they did not think it an object of any consequence to demand the restitution; and it was more a sense of honor than a regard to interest that led them to wish for the restorayol. I. I 2 


\section{NATURAL AND CIVIL}

tion of the country; having lost it by what they esteemed an English encroachment on therr claims, pride and honor urged the French court to effect the recovery of a country, which yet they believed was of little or no value. Cham. plain availed himself of these sentiments and feelings, and as the English monarch did not concern himself much about the matter, the solicitations of Champlain prevailed; and by the treaty of St. Germain's, Canada, Acadia, and Cape Breton, were restored to France in the year 1632 .

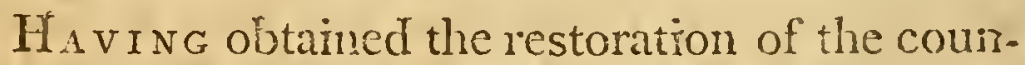
try, Champlain resumed his favorite gorernment and employment, and continued zealously engaged in the affairs of the colony till the month of December 1635; at which time he died governor of the colony, of which trrenty seven years before he had been the founder. Champlain is represented by the writers of that time, as a man of much penetraticn, integrity and activity. He could not have succeeded in founding his new colony, if he had not been active, enterprizing, firm and brave. The Ecclesiastical writers represent him as a man of great piety, and remarkably zealcus for the propagation of the catholic religion; and they record with great pleasure, one of his speeches, that " the salration of one soul was of nore ralue than the conquest of an cmpire." "The work in which he was engaged, required great abilities, and great virtues; without these he could not have succecded in establishing a new city and colony in the midst of numerous, warlike, and savage nations. *

- Charlevoiz Hist. Nouv. France. Tom. I. p. Igh. Abbe Raypat, Vol. 5. [1. I30. Ancer. Biogrephy, Val. I. 13. 341. 


\section{HISTORY OF VERMONT. 26.8}

IN all countries, the surceeding state of society seems naturally to ressilt from the measures and pursuits of an earlier policy. While zealously engaged in promoting the welfare of his new colony, it was the misfortune of Champlain to entail upon it the miseries and curses of war. Three of the most powerful of the savage nations, the Iroquoise, the Algonquins, and the Hurons, were engaged in a fierce and bloody war when Champlain was laying the foundations of Quebec.

The Iroquoise were spread over an extent of country, nearly eighty leagues in length, and more than forty in breadth. Their country reached to lake Erie, lake Ontario, the river St. Lawrence, and the countries which now belong to the States of Pennsylvania and Newyork. To the eastward it took in lake Champlain, and the western parts of Vermont, and the Indians on the banks of Susquehanna, Delaware, Hudson, and Connecticut rivers, were in a kind of subjection to them. The land between these extensive limits was fertile, abounded with game, and was watered by a number of fine rivers, rich in the plenty and variety of their fish. The inhabitants consisted of five nations, and contained many thousand warriors. Their five nations were formed into an united or confederate body, which vore the appearance of a number of confederate republics. In the grand council of the whole all the affairs of peace and war, and other general concerns were determined. These confederate tribes or five nations, formed a more powerful body than any of the adjacent nations. They were generally at war 
with the neighboring tribes, and on account of their numbers, power, and conquests, were become the objects of fear, dread, and aversion, to the other nations. At the time when the French were forming their colony in Canada, the five nations of the Iroquoise were engaged in a war with the Algonquins. and Hurons. The Algonquins lived along the banks of the river from Quebec to. Montreal. The Hurons were dispersed about the lake that bears their name. 'These, with some other tribes of less consequence, had suffered severely from the inroads of the Iroquoise : and were unable to make effectual opposition to their arms.

INSTEAD of attempting to introduce a recon: ciliation among these hostile nations, Champlain meaning to avilil himself of their quarrels, soon engaged in their wars, He took a decided part with the Algonguins, and went himself with the Hurons in their expeditions against the Iroquoise : He instructed them how to carry on their wars, was personally engaged in scveral of their battles, and in one of them received a wound not a little dangerous to his life.

TнE Indians saw with wonder and surprise the effect of the European arms, in the attacks which Champlain had made upon the Iroquoise at lake Sacrament, and other places. The $\mathrm{Al}$ gonquins and Hurons soon gave a friendly attention to the new settlers, and meant by their assistance to gain the superiority over their ancient and haughty foes. Of course they favored the settlement of the Frerch, gave them lands, courted their friendstip, ar:d invited them to settle in every part of their country; and by 


\section{HISTORY OF VERMONT. 265}

their assistance they obtained many and repeat. cd advantages over the Iroquoise. Nor was it until the five nations became accustomed to the effect of the European arms, that they could make any effectual opposition to an enemy, whom they had before defeated and despised. But instead of being subdued or disheartened by the new method of war, it served rather to inflame the haughty Iroquoise with the fiercest resentment against the French. They viewed the strangers who were settling in the country, as the most dangerous of all their enemies; and it became the first and most important of all objects to carry un a destructive, unceasing, and exterminating war with them,

Tне French were gradually extending their settlements upon the river St. Lawrence, and advancing further and further into the Indian country. In about ten years from the settle:ment of Quebec, they began the foundations of a fort and village at Trois Rivieres; and in 1640 they began a fortress and town at Montreal. Wherever they went, they assisted and encouraged the Algonquins; and they met with a steady and bitter enemy in the Iroquoise. The hostile Indian nations were an enemy, which the five nations wished to subdue; but the French were every where the chosen victims, and the objects of their inveterate hatred. To have taught a despised enemy how to conquer, to have introduced among them weapons every way superior to their own, were crimes which the fierce and savage temper of the hatughtiest of all the Indian nations, could not forgive or endure. Thus by interfering in the 


\section{NATURAL, AND CIVIL。}

quarrels of the natives, the French had brought upon themselves a fierce and bloody war, with the most powerful of all the Indian nations ; and produced an enmity, which appeared to be fix ed, permanent, and obdurate ; and such as the revenging spirit would endeavor to transmit from one generation to another.

$I_{N}$ the destruction occasioned by these wars, in the coldness of the climate, in the immense quantity of labor necessary to effect the settlement of the country, and in the fewness and poverty of the Europeans, there were causes which rendered the French settlements extremely slow in their growth, and very precarious as to their duration. In addition to these difficulties, the five nations were now become accustomed to the effect of the European arms, had procured some of them, and regained their customary superiority over their ancient enemies. Surrounded with so many dificulties, the French were full of apprehensions that the time was not far distant, when they should be forced to abandon the country. Their Indian allies whom they had once taught to conquer, were now continually flying before their ancient enemies, whom they had been accustomed to dread. And the Iroquoise, feeling the animation of their regained superiority, were become more fierce and insolent than ever : and were loudly boasting that they would not only sub. due their former enemies, but that they would soon force the French to leave their country, or put them all to death.

$I_{N}$ this distress the court of France interfer. ed to save the colony. A body of four hun- 
dred good troops were sent from France, in the year 1662; and these, in two years more, were res inforced with the regiment of Carignan. With this force, the courage and hopes of the colony revived. M. Courcelles, the governor of Canada, supposed it would have a good effect, to carry the war into the country of their enemies: With this view in 1665 he sent out a large party against the Mohawks, one of the five nations. The expedition was undertaken in the winter: Through ignorance of the country, and the want of proper snow-shoes, the whole army were near perishing, when they accidentally fell in with Schenectady, a Dutch settlement on the Mohawk river. At Schenectady, the whole party were in the utmost danger of being destroyed by the Mohawks. What prevented, was the interposition of one Corlear, a Dutchman. And such an impression was made on the minds of the Inidians, by the preservation which this man had afforded them, that they never forgot either his friendship, or his name. In all their treaties ever after, with the governors of Newyork, they always addressed them by the name of Corlear; an expression, in their view, significant of kindness, friendship, and confidence.

To retrieve the misfortunes of their winter expedition, in the spring of 1666 , twenty light companies of foot, with all the militia of Cana$\mathrm{da}$, marched into the Moharvk country. Their march was attended with great expence, and fatigue ; and continued for more than seven hundred miles, through an uncultivated and bostile country ; but did not prove destructive of many of their enemies. At the approach of 
the French, the Indians easily found places of safety, by retiring into the woods and swamps, where the French army could not follow them: Nothing was to be found but a few of their old sachems, who were super-annuated and weary of their lives, to gratify the fury of their enemies. The resuilt however was farorable to both parties. The French, exhausted with the expence and fatigue of the campaign; and mortified by the want of success, did not wish to repeat the experiment of another expedition in the Indian country. The Indians were not pleased to see the war brought into the heart of their own country, nor could they yet oppose a large body of men armed and disciplined in the European manner, with much prospect of suc: cess. While both parties thus wished to put an end to hostilities; it would not be difficult to find reasons, ways, and means, to effect a reconciliation. In this disposition of their minds, they agreed to put an end to their wars ; and in the year 1667, concluded a treaty of peace, which continued for several yeirs.

THIs was the first time that the French co. lony had ever enjoyed a compleat peace. Both the English and the French immediately embraced the opportunity to conciliate the affec: tions, and to cuitivate a trade among the natives; and their interest lead them to urge it, with much zeal and address. At that time the trade with the natives was attended with much profit and advantage to all parties. The French in Canada, and the English at A Ibany and Schenectady, were as yet too remóte from each other, and too few in numbers, to occasion any 


\section{HISTORY OF VERMONT.}

considerable differences, or intericrence in the indian trade. And the Indians who lived between the trio countries, availed themselves of the best markets and terms which they could find ; asserting in a wise and practical manner the doctrine of their independence, liberty, and equality with any of the European colonies. M. Courcelles however was not inactive duing this season of peace. He easily foresaw that a peace with the savages, could be of but a siort duration; and he was extremely active in ma. king preparations for the future defence of Canada. To prevent the irruptions of the Iroquoise into Canada, by the way of lake Cham. plain, in 1665 he built the forts of Chambly and Sorel; both on the waters by which the communication is kept up between the lake, and the river St. Lawrence. In 1672, under pretence of a treaty of commerce, but with a design to effect an establishment, which should serve to restrain or subdue the Algonquins and Hurons, he obtained their leave to build a fort at Cadaraqui on lake Ontario. His successor, Count Frontenac, compleated the works the next spring; ; and in 1679,M. de Salle inclosed. witi pallisadoes a spot of ground at Niagara, upon the strait which forms the communication between the lakes Ontario and Erie. Such was the origin of those fortresses, which have since occasioned so much expence of blood and treasure.

To this period, the wars in Canada had been confined to the French and the natives; neither the Dutch or the English colonies had been engaged or concerned in them. Albany, and all
VOL. I.
K 2 


\section{0 NATUKAL AND CIVIí}

the northern settlements on Hudson's river, had been conducted by the Dutch. That people, inclined most of all to commerce, had so managed the Indians as to secure their friendship, derive much profit from their tracle, and had always avoided any contests, or at least any open hostilities with them. In 1664, the whole country, called at that time New Netherlands, was surrendered to the crown of England. The country assumed the name of New York, and was gowerned by authority derived from the king of England. The Indians who lived between the settlements in New York and Canada, traded with either as best suited their convenience or interest. But from this intercourse they soon found that the English and French were far from being friends; that they were often at war with each other, and were always rivals in trade. With the spirit of sound policy they endeavored to avail themselves of this state of things, and to procure from the English a plentiful supply of that kind of arms and an:munition, which had been so successfully employed against them; and which could alone be applied to the greatest advantage in all the parposes of war and hunting. At the same time they resolved to preserve their own inde. pendence and importance, by trading with, or favoring tither, as their own interest might dictate.

Thв English and the French colonies were both aware of the Indian temper and policy, and they were anxious to secure the Indian friendship and trade. It became of course their interest and endeavour to impart their own 
maxims and prejudices, to the savages; and to attach them as much as possible to their own nation, views, and party. As war had now ceased, this was the time to try what could be done by the councils, measures and arts of policy and insinuation. In this kind of manœuvering, or Indian courtship, the French had the most address and success. They not only sent their traders, but they sent their Priests to reside anong the Indian tribes. The missionaries, educated in all the knowledge of Europe, studied the Indian temper and character; and soon became well acquainted with their business. Their superior knowledge and address gave a direction to the councils and measuras of the savages; their acquaintance with medical and chirurgical subjects, qualified them to become their physicians and surgeons; from their knowledge in the arts of life, the Indians were daily instructed in their rude attainments of fishing, agriculture, and making their cabins and weapons. To gain their affections, the fathers were distinguished by their attention to all the offices of humanity; and to these were added the arts and influence of superstition, as a still more effectual means of gaining an ascendency over the savage mind. In this kind of management the Jesuits were most of all distinguished: And it does not appear that in any other order of clergy, so much knowledge of science, of business, of men, of human life and conduct, were ever so well united. Wherever. they were sent they met with great success; and when their manners and conduct were compar. ed with the aukward and disgusting manners of 
the English missionaries, the natives concluded that the Jesuits were the men who were the favorites of the Great Spirit above; and that he neither did or would work much by the other missionaries; especially by the formal, unac. cornmodating; metaphysical English Priests.

To this influence and instigation of the French priests; the English ascribed the commencement of hostilities which took place in the year 1683, on the back parts of Virginia and Maryland, by some of the five nations. This was the first time that any of those nations had erer been engaged against the English; and the prospect of a war with the Iroquoise, occasion. ed a most serious alarm to the country. If they had proved so formidable to the French, when they had only their bows, arrows, and clubs, it was concluded they must prove a most formidable enemy now, when they were generally armed with guns and hatchets, and knew how to use them. To guard against so dangerous an event, a general convention of the English colonies was held at Albany in the year 1684. Lord Howard, governor of Virginia, was preant. Col. Dongan, governor of New York, and other infuential characters attended. The convention succeeded in averting the storm. Howard, as President, made a treaty with the five nations, and entered into a plan of peace, trade, and alliance. This covenant was again confirmed in 1685, and has been renewed at several other times, since that period.

WHILE the convention of the English colonies were engaged in this treaty with the fire nations, an event took place, which tended to 
give it success and efficacy. A niessenger arrived from M. de Barre, governor of Canada, complaining that the Indians of the Seneca tribe had interrupted the French, in their trade with the more distant nations. 'The Senecas admitted the charge, but complained in their turn that the French had supplied some of the Indian tribes with whom they were at war, with arms and ammunition. And it became known that while De Barre was amusing the governor of New York, and the Iroquoise with these complaints, he was making large preparations for the entire destruction of the five nations. That nothing might be wanting to secure success to his measures, he had procured fresh troops from France; and a letter of instructions from the Duke of York, proprietor of the province, to Col. Dongan his governor, enjoining him not to oppose the French proceedings. Thus prepared, De Rarre proceeded with an army of seventeen hundred men to lake Ontario; and sent to all the officers in the western posts, to collect all the Indians they could in the upper parts of the country, and rendezvous at Niagara.

THЕ interference between the Englich and French colonies in the affairs of the Indians, though not avowed, had resolved itself into a steady opposition for several years; and was now assuming the aspect of a regular notional policy. Dongan had been appointed governor of New York in the year 1682; and was the first English governor that saw the advantages which might arise from the Inclian conmerce and alliance. Aware of De Barre's measures and designs, he disregarded the orders which 


\section{NATURAL AND CIVIL}

he had received from the Duke of York ; ane nounced to the Indians the designs and preparations of the French, and promised to afford them his assistance. Encouraged by these advances from the governor of New York, the five nations became more and more attached to the English, and prepared to make a vigorous defence.

A $\mathrm{T}$ fort Frontenac, De Barre was detained six weeks in want of provisions and recruits. During this delay, a distressing sickness broke out in his camp, occasioned chiefly by the bad. ness of his provisions. Incapable of carrying on war in an enemy's country with a diseased army, he now wished to adjust his operations to the purpose of concluding a treaty of peace. With this view he crossed lake Ontario, and came to a place, which on account of the distress of his army was called la Famine. Dongan received intelligence of all his movements, and labored to prevent the Indians from attending his proposed treaty. Two of the five nations, the Mohawks \& Senecas were dissuaded, and refused to join. The other three, the Oncydoes, the Onondagoes, and the Cayugas, were influenced by the French missionaries; but were unwilling to hear the French interpreter, unless it should be in the presence of the priests, to whom they had been much attached. Matters were at length partially adjusted, and the sachems of three of the tribes agreed to meet the French governor.... Twodlays after their arrival in the French camp, the council was opened. De Barre attended by a circle of French oflicers andIndian, addressed 


\section{HISTTORY OF VERMONT.}

id speech to Garrangula, an Onondago chief: In his speech he told the Indians that he did not come into their country for the purposes of war, that his aims were altogether pacific, and that he had no other wishes or designs, but to conclude with them a treaty of peace and perpetual friend. ship. Garrangula replied, that he had heard and considered his talk, and did not believe it; that he knew that he came into their country to destroy them all ; that the great Spirit had put it out of his power, and that the Indians perfectly well knew the distresses of the French army ; that notwithstanding all their boasting, they were the objects of compassion, rather than fear; but notwithstanding they would go so far as to make a treaty with them. * Mortified and provoked at the bold and sensible answer of a savage, whom he meant to have despised and destroyed, De Barre was obliged to conceal his resentment, and his fear. Nothing remained but to conclude the best treaty the savagges wouid admit; and he retired to Montreal, mortified with the expence, the want of success, and the disappointment that had attended every part of the expedition; and not at all pleased with the terms or extent of the treaty which he had obtained.

M. de Barro returned to France; and the marcuis De ivconille being appointed to succeed him in the government of Canada, arrived at Quebec in 1685. The marquis was colonel of a regiment of dicigoons, of an active and enterprizing turn of mind; and was appointed 
for the purpose of removing the disasters and disgraces, which came upon the colony in the time of its former gotemor. As soon as De Nonville was become acriuanted with the affairs of the col. on , he wrote to cardinal Richlieu, the French minister, urging a pian to cnlarge and strengthen the rorks at Wiagara, to exciude the Er. glish alingether from the lakes, to engross the whole of the furr trade, and to subdre the five nations; and immediately began his operations by throwing large supplies of troops and provisions into fort lrontenac.

The governor of New-York watched all his proceedings, and was rery suspicious of his designs. He wrote to him that the five nations were his friends and allies, and that an attack upon them would be considered as a breach of the peace which subsisted betiveen the English and the French crowns. He objected to his sending so poweriful a force to fort Frontenac, and protested against his building a fort at Niagara ; claiming that part of the country, as a part of the province of New- $\mathrm{X}$ ork. In his answer, De Nonville denied any intention of invading the five nations, but claimed the country at Niagara, as belonging to the French crown. Dongan placed no confidence in the declarations of the marquis : Aware of his preparations and designs, and of the importance of the Indian alliance and commerce, he exerted his influence to encourage and prepare the confecierate tribes for war; and was constantly at work to make all the opposition in lis power, short of actual instiities, to the plans and proceedings of the French governor: 


\section{HISTORY OF VERMOKT.}

"T не five nations, at that time, had been fors tunate in their victories over some of the Indian tribes with which they were at war; and with whom, the French had carried on a lucrative trade. To prit an end to their triumphs, and to the obstruction which they gave to the French trade, De Nonville determined to carry war into their own country. To effect these purposes, in 1687, he assembled a body of two thousand French troops, and six hundred Indians at Montreal; and directed all the officers in the upper parts of the country to meet him at Niagara, with all the force that they could collect. While these preparations were taking place, hostilities were commenced. Two parties of the English, who were trading on the lakes were seized by the French, their effects were confiscated, and their persons imprisoned. A French officer with two or three hundred men, had surprized two villages of the confede. rates, whom they had invited to settle in their country: And so anxious were the French to prevent any of these Indians from escaping, and carrying the intelligence to their countrymen, that they were all conveyed to fort Frontenac. In the treatment of these captives, the French exceeded the barbarities of the savage tribes: All the captives, thirteen excepted, were burnt at the stake; and spent their last moments in singing with an heroic and undaunted spirit; the baseness aind perfidy of the French. The rest, by the particular order of Lewis XIV. were put in irons, sent to Quebec, embarked from thence to France, and there put on board the gallies. 
Hostilites being commenced, the interests of the French colony now recinired vigorous \& animated exertions. De Nonville was not cieficient in courage or chterprise. On the twenty third of June he cmbirked his whole army in canoes, and set ont from fort Cadiuriqui one half procected on the noith, and the other half marched on the south side of the Oneida lake: They met the same day, at the place appointed for their rendezvous, seven leagues from the chief village of the Senecas. The Indians were placel in the front, and rear; the main body, consisting of the regulars and rilltin, were lept together in a reguiar form. On the second day of their maxch the scouts arrived at the cornfieldis of the Senecas, and within pistol shot of five hundred of the warriors of that nation, who lay on their bellies undiscovered. The French conclucied that the Senecaswere all Acd, and were. in full marcli to overtake the old min, the wo. men, änd chilarren. In this state of rapid move. ment, and high expectation, they arrived at the bottom of an hill, within one mile of the Seneca village. In a moment the war-shout and yell of the Senecas, was heard from erery sicle ; and the French army was attacked fom every quarter. The whole army was struck with sur. prise and horror, and universal confusion ensued. The regulars and militia seized with the panic, could neither preserve their orcler or exert their force to any adrantage. One battallion fired upon another, and all endeavored to fly into the woods. Expecting such a scene, the. Senecas rushed on with impetuosity to increase. the confusion; and would have compleated the. 
defeat of the whole army had it not been prevented by the superior prowess of the French Indians. Accustomed to such scenes, they understood the business, and the outrage of an Indian attack ; rallied their forces, rushed on to the attack, repulsed the Senccas, and saved the army of the French.

So dispirited was the French general by this unexpected and alarming onset, that he could not be pursuaded to make any further attempts that day, or even to pursue the retreating enemy. While he was collecting his spirits and his troops, the Senecas burnt their town and marched off with safety into the woods; leaving nothing but two of their oldest men, for the French to kill and torture. A!l the exploits that remained for De: Nonville. was to burn the cornfields belonging to the Indian village, and make captives of the two old men. Having compleated this business he marched his army back to lake Ontario; and erected a fort on the strait at Niagara. To preserve this fort, he left a garrison of one hundred men; all of which, except seven or eight who escaped, being closedy blocked up by the Senecas, perished in a few months by famine.

RECEIVING intelligence of the event of De Nonville's expedition, the governor of NewYork concerted measures to avail himself of the porrer and friendship of the Indians. For this purpose he repaired to Albany, and had a conference with the five nations in the month of August. His speech on that occasion was well adapted to secure their confidence and dependance. He rejoiced, he told them, that the 
had not suffered a greater loss by the French, whose designs undoubtedly were to destroy them all ; and that he would provide them with such necessaries as they wanted. He advised them not to destroy their captives, but to keep them as prisoners, for the redemption of their own countrymen whom the French had taken: To keep up a corresfondence with him as to all their designs and measures; to send away the French priests from their country; to point out a place on Lake Ontario, where he night build a fort to supply them with stores and provisions; and above all not to pretend to make any treaties with the French, but by his advice and consent. of Dongan served to encourage and animate the Indians. Soon after a considerable party of them beset the French fort at Chambly, burned several of the houses, and returned to Albany with a considerable number of captives. A. bout the same time forty of the Onondagoes surprised some of the French soldiers at fort Frontinac, whom they confined and reserved for the redemption of their countrymen, who had been sent to the gallies. Great pains were taken to recover these Frenchmen out of the hands of the Indians. 'The French priests interposed to persuade the savages to treat them with kind. ness, and return them to their countrymen; and a message was sent to the governor of New York, to engage his infuence in the affair. Diongan informed the governor of Canada that tho peace could be made with the five nations,

4mith's Hist. New-York, p. 6g. 


\section{HISTORY OF VERMONT. 281}

unless the Indians which had been sent to the gallies were returned, the forts at Frontenac and Niagara demolished, and satisfaction given for the damages which had been done to the Seneeas.

IN this situation of the French affairs, Dongan hoped to compleat his favorite plan of policy ; to compel both the French and the Indians to apply to him, in all their affairs of peace and war. He had nearly effected his plan with the Indians; but the French governors were jealous of his designs, and wished to treat with the Indians, as a nation independent of the English crown or colonies. "It was however in Don. gan's power from the situation of the French colony at that time, to force it into such kind of concessions; and he was steadily following measures to effect the purpose, when he was ordered by Jares II. one of the most obstinate and infatuated of all the English kings, to give up the point to the governor of Canada; and to use his influence with the five nations, to make peace with the French,

DEPRIVED of the assistance and councils of Dongan, the five nations began to hearken to the French invitations, and a general meeting of the hostile parties was proposed at Montreal. Twelve hundred Indians of the five nations attended at this conference, and insisted with much earnestness, on the terms which Dongan had recommended. De Nonville declared himself ready to put an end to the war, if the Mohawks and Senecas as well as the other tribes would agree that the French should not be hindered in supplying fort Frontenac with provisions, Ac. 
cording to the French accounts the conditions "were acceded to, and a treaty was agreed upon by both parties.

$I_{T}$ proved however of no avail. The policy of one Indian was sufficient to destroy every idea of confidence between the parties, and to inflame both still more with the spirit of bitterness and revenge. Among the tribes which lived on the shore of the western lakes, there was one called by the name of the Dinondodies; a party, or appendage to the Hurons. This tribe had found it profitable to trade with the English, at Michilimacinac.' On that account it was suspected by the French, as being inclined to withdraw from their alliance; but it was still at war with the confederates. Adario, called by the French Le Rat, was their chief. With a policy perfectly similar to that of Europé, he wished to clerive advantages to his cwr tribe, from, the follies, jealousies, and wars of the belligerent powers. His wish and riew was to prevent the peace between the French and the five nations. If he could effect this purpose, it would secure his own tribe from the attacks of the French, or Iroquoise; render their friendship of much importance to both; and at the same time secure his own infuence, popularity, and power with his own tribe. "To effect these purposes, he put himself at the head of one hundred men, and marched to intercept the ambassadors of the five nations, who were going to compleat the business of peace with the French governor. At one of the falls of Cadaraqui river he met the Iroquoise ambassadors; killed some, tcot others prisoncrs, and informed theis 
that it was the French governor that had given - him intelligence that fifty warriors of the fixe" nations were coming that way.

To be betrayed by the person with whom they had agreed upon a treaty, and were now going to confirm it; and at the same time to be dclivered into the hands of a party with whom they were at war, exceeded all the coriceptions the savages had been able to form of duplicity. perfidy, and baseness ; and in their rage against De Nonville, they declared to Adario the nature. of their business, and the design of their journey. Adario instantly put on all the appearances of anger, shame, and distress, at being made the executioner of De Nonville's baseness and treachery. He flew to the principal of the amtassadors, cut his bands, and set him at liberty. "Go, says he, my brother, return to your nation, and tell them it was the French who'led. me to commit so base and vile an action, as to make an attack upon the messengers of peace. "Though our nations are at war, you are at liberty ; and I shall never be at rest, till you hare. revenged upon the French, the base and perfidious conduct into which they have betrayed me." By these arts, similar to those of more polished. nations, Adario secured peace for his own tribe, and lefi the contending powers more exaspera-s ied against each other than they had ever been. before.

TrE intelligence soon reached the five nations that their ambassadors had been intercept: ed; and assaulted by the contrivance of the French governor; and they did not doubt of whe truth of the information. The whole nation. 


\section{4

vowed revenge, and agreed to make retaliation:

Twelve hundred of their warriors, animated with the fiercest feelings of the savage heart set out on a march to Montreal. The inhabi. tants, unacquainted with the attack upon the ambassidors, and believing that peace was made with the five nations, were in perfect tranquility, without any preparation for, or any apprehension of danger. While the city was thus serene, and without fear, the storm of rengeance gathered and burst. On the 26th of July 1688, the Indian warriors landed on the south side of the island of Montreal, and immediately began their assault upon every part of the city. Nothing could exceed the destruction which the savages carried with them. They burnt the houses, sacked the plantations, and put to death every man, woman and child, which they could find without the fortifications. One thousand of the French were slain in this massacre; and twenty six were carried into captivity, and burnt at the stake. And so great was the consternation of the Erench, that the Indians lost but three of their number, while they carried destruction and carnage through the whole island. Not satisfied rith the calamities they had already occasioned, in October the Indians made another descent upon the island; again destroyed the lower part of it, killed several of the inhabitants, and took many prisoners.

AT no time had Canada ever before, met with so heary a misfortune. The very news carried defeat as well as alarm along With it. On receiving the tidings, the garrison at Lake Ontario set fire to two barks which they had 
Just compleated, and abandoned the fort ; leav. ing a match to twenty eight barrels of powder, disposed with a design to blow up the works. 'The troops went down the river with such rapidity and fear, that one of their battoes, with hier crew, was sivallowed up in one of the falls. The confederates were in all the animation and insolence of victory : They seized the fort at Cadaraqui, with all the powder and stores; they sent their scouts every where, to invade the frontiers, and break up the settlements in Canada. The French were involved in every kind of difficulty and danger; their borders were invested, inroads made on their oldest plantations, their new settlements breaking up ; it became difficult and dangerous to cultivate the lands, or to gather in the harvest: And to all the miseries and calamities of war, were now added the distresses of famine, to compleat their catalogue of woes. Their Indian friends and allies forsook them, and made peace with the Iroquoise and English. 'Two only of the Indian tribes adhered to the French in their calamity; and these were too much dispirited, to attempt any thing in their favor; and it was only in the cities of Queber. Trois Rivieres anit Montreal, that the inhabixints of the colony' found any safety: The savages knew not how to approach, or to carry any fortified works; and the French availed themselves of this circumstance, till the affairs of the colony took $a$. different turn.

VHILE the Iroquoise had been carrying on these measures against the French, a war had broke out between the Abenaquies and the yoL, M 2 
English colonies at the eastward, which bore a threatening aspect. It was understood by the English, that there was not any alliance between the Iroquoise and the eastern Indians; but rather, some remains of former hostilities and jealousies: And it was hoped that the fierceness of the sarage temper and passions, might be managed so as to draw them into a war with the eastern tribes. To effect this purpose, commissioners from the colonies of Massachua setts, Plymouth and Connecticut, had a conference with the five nations at Alibany, in September 1689. When urged to engage in the eastern war, the Indians replied that it was not their custom to go to war with any people, from whom they had not received any injury or in. sult; that they were engaged already in a war with the French, the conmon enemy ; and that they believed the best policy would be for the English colonies first to assist them in subduing the enemy, that was always ready to make war against them both. The speech which their orator made on this occasion, is an amusing specimen of the Indian genius, policy and eloquence. The English commissioners learnt from it, but with : uprise, that the Indians well understood their own interest and affairs ; and rwere as much disposed and qualified to avail themselves of policy in the management of war. as the Europeans who had got possession of their country。 


\section{CHAPTER X.}

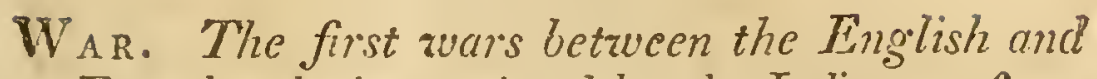
French colonies, assisted by the Indians; from the year 1689 to 1750 . Effect of the revolution in favor of IVillian and Mary. Plans of the French. Destruction in New Hampshire and Schenectady. First attempt to reduce Canada. Sentiments of the Indians on that occasion. French expeclition against the Mohawks. Destruction of Deerficld. Second expedition aigainst Canada. Proceedings. of Schuyler. Third attempt to redhuce Canada. Proceedings at Oswego and Lake Ontario. Buildings and settlement at fort St. Frederick at Crown Foint. Capture of fort Massachusetts. Proposed expedition against Crown Point. Attempt upon the fort at Charlestown.

THE wars which had hitherto taken place in the northern parts of the country, had been chiefly between the natives and the European colonies. The English and the French colonies had made it their practice to assist the Indians with arms, ammunition, cloathing and provisions, when they were going to war, either against each other, or against the opposite colony ; but neither of them had as yet adopted the custom, of joining their own troops to the Indians, or sending out parties to aid or assist thean in their expeditions.

Col. Dongan, who was governor of Newyork under James II. was expressly commanded by his sovereign, to avoid giving the Indians any 
assistance, or the French any molestation. A dupe to his bigotry and to his priests, it seemed to be the great object of the English king, to have the Irench missionaries succeed in conrerting the American Indians to the faith and ceremonies of the church of Rome; and that every political movement in the province of Newyork might be directed to favor that erent. Dongan was an arowed roman catholic, but had more understanding than to sacrifice the political interests of his colony, to the dangerous design of making the Indians a ncw sect of believers in the catholic priests. He forcsaw the political consequence and effect, avoided the civil politics of his master, opposed the views and measures of the governor of Canada, and gave much assistance to the Indians in their opposition to the French; and the governor of Canacla was full of his complaints, that all his measures were opposed and defeated by the governor of Newyork. But this strong and mutual jealousy and opposition between the governors of Newyork and Canada, was much restrained, and kept from any open and arowed hostilities, by the friendship and good understanding, which at that time prevailed, between the kings of England and France.

HAPPILY for the English nation, the folly, bigotry, and arbitrary measures of James II. were carried to such an excess, as to alarm all orclers and degrees of men. In the event, they prepared the mind of the nation for a revolu. tion; - which terminated in the abdication of James, and in the elevation of William and Mary to the English throne. In his perplexity and dis. 
tress, James fled into France for protection. Lewis XIV. avowed his cause, and afforded him assistance in his encleavors to recover his throne. These events, according to all the European customs and maxims, could not fail of producing hostility and war between England and France.

IT was the fate of the colonies at that time, not to partake much in the prosperities, but to be involved in all the misfortunes and quarrels of their parent states. No sooner had England and France plunged themselves into all the calamities and distresses of war, by the vices and follies of one of their worthiess kings, than all the people in their colonies must share the same fate, and be involved in the same pursuits and sufferings. And the time was now come in which both the French and the English colonies were destined, not only to carry on a war with nations of barbarous natives; but to become parties and sufferers in all the quarrels of more cautious, but equally :capricious European sovereigns.

M. De Callieres, seems at that time to have had the management of their military affairs, in Canada. Of an active disposition, and sound judgment, he concluded that the surest w'ay to subdire the five nations would be, to effect the conquest of the province of Newyork. The plan that he proposed was to attack the city of Newyork by sea, and that a large body of Canadians and Indians should march by the way of Sorel and lake Champlain, to take Albany. In pursuance of this plan he went to France in 1688, and presented a memorial to the French 
king on the subject. The force which he re. quested for these purposes, was thirteen hun. dred regulars, and three hundred Canadians. Albany was said to be fortified only by an in. closure of stockadoes, and a little fort, with only four bastions; and that it contained but. one hundred and fifty soldiers, and three hundred inhabitants. The capital of the province, Newyork, was described as defended only by stone fort, with four bastions; and containing four hundred inhabitants, divided into eight companies. The Court of France acceded to. the proposals and solicitations of M. De Calieres. A French fieet and troops were sent to. Chebucta ${ }_{2}$ in September 1689 , to proceed to Newyork, as soon as the troops should have marched towards Albany. The Count De Frontenac proceeded to Giuebec, to put himseif at the head of the Canadians, and Indians, in their march to Albany, On his arrival at Quebec, he found the andirs of Canada in great confusion. He learnt with astonishment that the Iroquoise liad plundered and burnt the city of Montreal, and killed most of the inhabitarits; that the frontier'settlements were broken up, and the inhabitants of Canada in such a state of weakness and poverty, 'that they could not undertake any expedition against Albany. 'It was in vain for Frontenac to attempt a conquest of Newyork, while the French colony was in such, a situation; and he was obliged to give up an. expedition, on which his heart had been much. angaged. * Thus carly did it occur to the

- Carleveir. Fmith's Hist, Newyork. 


\section{HISTORY OF VERMONT.}

minds of military men, that whether Newyork or Canada were to be conquered, the passage of the army must be through lake Champlain.

Mortified by the failure of the proposed expedition against Newyork, and alarmed by the distressed state of Canada, the count found it to be absolutely necessary to revive the hopes of the Canadians and Indians, by some attempt: against the English colonies: With this viers he projected two incursions; one against the eastern frontiers of Massachusetts and NewHampshire, and the other against the northerly settlements in the province of Newyork. The former was put under the command of Sieur Hertel, who set out from 'Trois Rivieres, and succeeded in the destriction of the fort at Salmon. Falls in New. Hampshire, on March 18th, 1690 . "Thirty of the English were killed, and fifty four, chiefly women and children, were carried into captivity: *

THE other party designed against NewYork, was put under the direction of D'Aille: Bout, assisted by De Montel, and Le Moyn. Under their command, a detachment of about two hundred Frenchmen, and fifty Indians who were well acquainted with the country, set out from Montreal, in the beginning of January, and proceeded by the way of lake Champlain. By the advice of the Indians, instead of proceeding: to Albany, they directed their march towards Schenectady, a village about, seventeen miles northwest of Albany. After a march of twenty two days, they arrived in the vicinity of the

- Relknap's Hist. Now-H.mpshige, Vol. I. g. 250 . 
village; but were reduced to such wants and distress, that they apprehended they must sur. render themselves prisoners of war, as the only alternative to prevent perishing by hunger and cold. To ascertain whether there was any pros. pect of success, they had sent foriard their scouts to gain intelligence. The spies were one or two days in the village, without being dis. covered or suspected. On their return to the French army, they informed the commander that the village was in a state of the greatest inattention; that the troops were few, and under no discipline; that the gates were not shut even in the night; that no preparation of any kind was made for war; nor did the inhabitants appear to be in any degree apprehensive of danger. Encouraged by this intelligence, the French officers determined to move forward, and make a viororous assault upon the place. On February the eighth, 1690, at eleven o'clock at night, they. entered the city by the gates, which they found open; and that every house might be invested at the same time, they divi. ded themselves into small parties of six or seven to a division. Never was there a place, that was more compleatly surprized. The inhabitants were in their beds without fear, and without any suspicion of danger ; the noise and violence of the onset, awakened them from their slumbers ; but before they had risen from their beds, the French and Indians had entered their houses, and began the work of destruction and slaughter. Col. Schuyler, commander of the military force in that part of Newyork, has given the most accurate account of this tragedy: 
"Notongue," says he, "can express the cruelties. that were committed. The whole village was instantly in a blaze. Women with child ripped open, and their infants cast into the flames, or dashed against the posts of the doors. Sixty persons perished in the massacre, and twenty seven were carried into captivity. The rest fled naked towards Albany, through a deep snow, which fell that very night in a terrible storm; and twrenty five of these fugitives, lost their limbs in the flight, through the severity of the frost." "**

Tн $\mathrm{E}$ news of this awful tragedy reached Albany, about break of day. An universal dread and constemation seized the inhabitants; the enemy were reported to be fourteen hundred in number; and many of the citizens of Albany entertained the idea, that the best method was to destroy the city, and abandon that part of the country. But Schuyler and others roused and rallied the inhabitants. A party of horse was soon sent off to Schenectady, but they were not strong enough to venture a battle. The enemy kept possession of the place till the next day at noon ; and having plundered the whole village, they went off with forty of the best horses loaded with the spoil ; the rest, with all the cattle they could find, lay slaughtered in the streets.

THE policy of the French was apparent in the midst of these horrid transactions. They not only spared the Mohawks whom they found in the place, but several other persons were released at the request of these Indians, with whom

* Smith's Hist. INewyork, p. 82.

VOL. I. N 2 
they wished to be at peace. Captain Glen was a citizen of note in the village: His wife, in the ime of Coi. Dongan, had shewn many civilities to some krench captives. The enemy offered no riolence to this man, and released sercral iromen and children at his request; de.. claring they hic strint onders not to do him any injury on account of the former conduct of his wife. The people of Schenectady had been informed of the design of the enemy, and that an expedition was lindertaken against that part of the country; but they judged it to be impos. sible for any body of men, in the severest season of the year, to march several hundred miles, through the deepest snows, with their provisions on their backs. "The civil groremnent of the province, at that time, was incapable of affording them any intelligence, or protection; universal weakness and disorder were spread through the whole province, by a revolution at at New York, under the direction of a captain Lester.

Tre success that attended these capeditions, was greatly farorable to the riews of Frontenac, and served to revive the spirits of the French colony : At the same time they cccasioncd an alarm in every part of the English plantations; and it was apparent, that miess they could be checked, New England and Wow York would receive much greater injuries and insults. It was proposed that there should be a mecting of commissioners from all the New Fingland colomies, and from the province of New Vork, to constit, and agree upon measures for the common defenee and safety. Commissioners for 


\section{HISTORY OF VERMONT. 295}

that purpose asscmbled at the city of New York, May 1, 1690 ; it was their unanimotis opinion that there would be no permanent peace in the English colonies, till the French in Canda were subilued; and that the only effectual measures would be, to engage upon an expedition for that purpose. To effect the conquest of Canada, they agreed upon this plan of operations ; that eight or nine hundred Eriglishmen, with five or six hundred Indians, shculd proceed by way of lake Champlain, and make an assault upon Montreal; while a feet and army of eighteen hundred or two thousand men, should go up the river St. Lawrence, and make an attack up. on Quebec, at the same time. By thus penetraing into the heart of the country, and carrying the operations and ravages of war to their two capital cities, it was supposed that the forces of the enemy would be, so divided, and their councils so perplexed, as to aftord a fair prospect of sticcess to the English armaments; and might probably tcrminate in the corquest, or at lc...it in preventing any further insults from Canada.

A small vessel had been sent express to England in the beginning of April, with a representition of the exposed state of the English colonies, and the necessity of reducing Canada; earnestly requesing a supply of ams and ammunition; and that a wumber of the lings frigates might be sent to maie the attack by sea, while the colony force should invade the country by land. Whe English nation, involved in a war with France, was in no situation at that time to afford any assistance to the expedition; 
and having waited till Auģust in hopes of stores and aid from Engiand, the colonies determined to proceed. Massachusetts agreed to fit out the force that was to proceed to Quebec; New York and Connecticut were to furnish the army that was to advance against Montreal.

Th e Connecticut and Nerw York troops were put under the command of John Winthrop, Esq. of Connecticut ; who was appointed major general and commander in chief. Early in the month of August he arrived with the troops under his command, near the falls at the head of Wood Creck. This was the place appointed for the rendezvous of the Indians of the five nations. But instead of finding a numerous force as he expected, there were not more than seventy rarriors of the Mohawks and Oneydoes. A messenger was sent to the other nations to per. suade them to send on their warriors, but they did not come forward to join the army. When the general had advanced about one hundred miles, he found that there were not battcaux or canoes provided, sufficient to transport one alf of the English army ; and that the commissary had not made preparation to supply the arniy with provisions. 'The Indians told them it was too late in the rear to make canoes; and that it would be best for them not to attempt Montreal, but to direct their attacks against Chambly, and the French settlements on this side of the river St. Lawrence. Discouraged with the difficulties and prospects before him, Winthrop called a council of war ; in which it was determined that the army must return to Albariy for subsistence, and to send on about an hundred 
and forty of their active young men, English and Indians, to make a diversion in favor of the fleet. ABOUT the same time, August the ninth, that Winthrop set out for Albany, the ficet sailed from Boston, for Quebec. It consisted of between thirty and forty vessels; the largest of forty four guns, and the whole number of men about two thousand. Sir William Phips, governor of Mlassachusetts, had the chief command. 'The fleet had a long' passage from Boston, and did not arrive before Quebec till the fifth of October. From the lateness of the season, and the retreat of Winthrop's army, Sir William Phips could have had but little prospect of success. Count Frontenac had advanced with all his forces to Montreal, to defend that part of the country against the army, which was advancing by way of lake Champlain. No sooner had he received advice by his scouts that the English army had retired to Albany, than he set off with the greatest dispatch for Quebec, and arrived in the city before the English fleet had come to anchor. The baron Le Hontan, a French officer who was then in Quebec, gives this account of the proceedings; that count Frontenac was at Montreal when he heard that the English fleet was in the river; and had the English made their descent before his arrival at Quebec, or two days after, they would have carried the place without any contest; as there were not two hundred French in the city, and it was open and exposed in every part; but that they lost the opportunity, by spending three days in consultation, before they came to any determination how to act. 
ON the eighth of Octobcr, the troons were landed, amounting to between twelve and thirteen hundred men, and advanced towards the town. The next day the ships were drawn up before it, and cannonaded with all their force. They did but little danage to the enemy, but were much shattered by the cannon from their battcries: On the eleventh, ihe troops were re. cmbarked. They had adranced, and maintained their ground with spirit, but they received such an account of the strength of the French from a deserter, as discounaged them from any further attempt. Nor was there any prospect that they conld succeed, when they had to oppose the whole force of Canada, under so able a commander as Frontenac. In a few days tempestuous weather came on, which drove sorze of the vessels from anchor, and scattered the whole feet; and they made the bust of their way to Poston, where Sir Villiam Phips arrived on the nineteenth of Norember.*

Such llas the fate of the first attempt of our ancestors for the conquest of Canada. from the ill success which attended it, it has been customary for the English and French writers to speak of it in the longuage of derision and contempt. With the multitude, success generally passes for wisdom, and mislontune is estecmod to be folly. The plan of the expedition was the same, that was twice afterwards adopted by the statesmen and generals of the British nation. Its success depended on the joint operition of the forces under the command of Winthrop and

* Hutchinson's IFist. of Maseacluactie, Vol. I. p. 4c0. Tïmbuil's Iist. of Connecticut, p. 402. 
Phips. Unfortunately the colonies wasted the summer in a fruitless expectation of succours from England. When Winthron proceeded to the lake, the Indians saw that it was too late to make the recessary preparations to embark his army ; and they rould not venture to join him in any considerable numbers. Unabie to proceed he was obliged to return to Aibany. Thiss retreat proved fatal io the attempts at Quebec. When opjosed by the whole force of Canada, Phips could not succed either in taking, or in holding the capital of the country.

THE fruitess attempts of the English colonies to subdue Canada, lefi very unfavorable impressions on the minds of the Indians of the fire nations. "Whey saw a precarious dependency of the colonies on a distant and unknown naton, wich they could not comprehend; a waste of time, which appenred to them to be unnecessiay, and d want of that unanimity, secrecy, energy, and perseverance, which were generaily to be found in their own councils, and in those of the French; of course they became apprehensive that their new allies had not the necessary information, or pover, to subdue their cnemies. Major Schuyler, of Albany, Was acquanted with the Indian character, and discenned the depression of their minds. $T Q$ keep alive, and to animate their enmity and hostility against the French, in the summer of the year 1691, he put himself at the head of a party of Mohewls ; and passing through lake Champlain, made a vigorous. irruption upon the French settlements on the river Sorel. He was opposed by M. De Callieres, the governor of 
Montreal, who with an army of cight hundred men, was encamped at La Prairie. Several engragements took place between the hostile parties, and in these encounters Schuyler slew about three hundred of the enemy; a number which exceeded that of his own force. While the French kept their troops together in the European form, Sichuyler aclopted the Indian method of placing lis men under cover of trees and swamps; and derived great advantage, from this method of carrying on his assaults.**

Amrds these invasions of Canada, Frontenac, though far advanced in age, being above sewenty, preserved his vigor and activity ; and was perpeinally planning; some enterprize for the benefit of the colony, and animating cvery body around him. Having failed in his at. tempts to make peace with the five nations, he was now meditating a blow upon the Mohawks. The force he collected for this purpose, amounted to six or seven hundred French and Indians. Well supplied with every thing necessary for a winter campaign, the ariny set out from Montreal, January 1.5th, 1695, and marched by the way of lake Chimplain. Persevering through incredible hardships, they passed by Schenectady on February the sixth, and that night captured five men and some women and children, at the first castle of the Mohawks. They met with the same success at the second castle; the Indians being in perfect sccurity, and many of them gone to Schenectady. At the third, they found about forty Indians engaged in a

- Snuth's Hist. New York, p. 32. 
war clance, and prepared to go out the next day apon some warlike expedition. Entering the mohawk castle, a warm conflict ensued, in which. the French lost thirty of their men; but they carried the Indian fortress, and captured nearly three hundred of the Mohawks, but mostly women and children.

ThE misfortunes of the Mohawks were no sooner known at Albany, than Schuyler put himself at the head of two hundred volunteers, and marched in pursuit of the enemy. On the fifteenth of February he was joined by three hundred Indians, ill armed, and many of them boys. With this force he fell in with the enemy, who had made some attempts to fortify their camp. Having still the advantage in the number and discipline of their troops, the ene. my made three successire sallies upon Schuyler, but in every one met with a repulse; and Schuyler firmly maintained his ground, every moment expecting a reinforcement and provisions from Albany. Fearful of that event, the French on the eighteenth, embraced the opportunity of a heavy snow storm, and marched off for Canada. The next day eighty regular troops arrived, with provisions from Albany. Schuyler resumed the pursuit, and it was by means of a floating cake of ice, that the French army were able to escape over the north branch of Hudson's river. But so pressed were they by Schuyler's pursuit, that they suffered most of their prisoners to escape. In these engagements Schuyier lost eight of his men, and fourteen wounded; the loss of the French was eighty killed and, thirty wounded. Both parties
VQL. I
O 2 
suffered severely by the severity of the weather. and the want of provisions. "The Mohawks found about thirty of the French, which had. been slain; such was their hunger and rage, that they roasted their bodies, and eat them for provisions. The French, in their turn, were so rediced that they eat up their shoes before they arrived in Canada. *

Ifon several years after this period, the war was continued wh much activity and animosity. Scouting and ravaging parties of Indians were frequently making inroads upon the English and French settlements, many rere slain on both sides, and much injury was done to the advanced settlements of both countries. Frontenac was also much engaged in erecting forts, and making excursions in the Indian country, to restrain and bridle the fire nations. But as these expeditions were at a distance from lake Champlain, they do not come within the proposed limits of this marration. Nor did the war cease on the frontiers of Canada, New York, or New England, till the ptace of Ryswick, September 20, 1697. The treaty between the two crowns of England and France, by putting an end to the Eirropean wars, restored tranquility to the Indians, and to the American provinces.

THE tranquility of the provinees, however was to be of but a short duration. Upon the death of James 1I. the king of France did not admit the prince who was in possession of the English throne, and acknowledged by the English nation, to be their rightful sovereign ; ans?

* Smith's Hust. of Niew York, p.95. 
proclaimed another person to be king of England. This affront could not fail to engage those mighty kingdoms in war, and to involve their American colonies in all its effects and sufferings. On May 4, 1702, war was proclaimed between England and France; a signal to the people that mutual hatred, hostility, and destruction were to begin. Att first the war did not prove distressing to New York. Count Frontenac, the able and vigilant governor of Canada, died in the year 1698 ; and his successor, M. De Callieres, had succeeded in compleating a treaty of peace and neutrality with the five nations. 'This agreement was allowed to be in force by the governors of New York and Canada, notwithstanding the war between the two crowns. And instead of being harrassed by the inroads of the French and Indians, the province of New York continued for some time in a state of great tranquility, and carricd on a lucrative trade with the French and Indians in Canada, at the very time they were carrying destruction into the other English colonies.

While New York was thus enjoying peace, the French and Indians were carrying uncommon destruction and calamities into the eastern provinces. In August 1703, a body of French and Indians, five hundred in number, divided themselves into several small parties, and assaulted all the settlements from Casco bay to Wells. They killed, and captured, one hun. dred and thirty of the English; burning and destroying the houses and settlements. The whole eastern country was in terror, and con- 
fusion ; alarms were every where taking place; and the whole frontier from Deerfield on Connecticut river, to Casco bay on the sea coast, was kept in one continual terror by small par. ties of the enemy.**

Ty e neutrality which New York maintained with the French and Indians, and the supplies which they afforded them in their descents upon the eastern colonies, was extremely blamed and censured in all the New England colonies. It was however attended with one good effect; the Indians, in their trading visits to Albany, frequently gave accounts of the expeditions the French were preparing against the eastern colonies : and Col. Schuyler never failed to give the most faithful and early intelligence of such designs. Deriving his information from this source, lord Cornbury, governor of New York, advised Mr. Dudley, governor of Massachusetts, so carly as the month of May, that the French and Indians intended to make a descerit upon Deerficld. The design not being carried into execution in the course of the summer, the intelligence was not enough regarded. But the next wintcr, 1704, M. Vaudrieul, governor of Canada, resumed the project with much atten. tion.

DEERFELD, at that time, was the most nor. therly settlement on Connecticut river, a few families at Northfield excepted. Against this place M. Vaudrieul sent out a party of about three hundred French and Indians. They were put under the command of Hertel de Rouville,

* Eelknap's Hist. New Hampshire, Vol. I. p. 331-332. 
assisted by four of his brothers; all of which had been trained up to the business by their father, who had becn a famous partizan in their former wars. The route they took was by the way of lake Champlain, till they came to the French river, now cailed Onion river. Advancing up that stream, they passed orer to Connecticut river, and travelled on the ice till they came near to Deerfield. Mr. Williams, their minister, had been much apprehensive of danger, and attempted to make the same impression on the minds of his people, but not with sufficient succcss; but upon his application the government of the province had sent a guard of twenty soldiers for their assistance. The fortifications were some slight works thrown round two or three garrison houses, but were nearly covered in some places by drifts of snow. To this place, Rouville with his party, approached on February the twenty ninth. Hovering round the place, he sent out his spies for intelligence. The watch kept the streets of the town till about two hours before day, and then unfortunately ail of them went to sleep. Perceiving all to be quiet, the enemy embraced the opportunity and rushed on to the attack. 'The snow was so high, that they had no difficulty in jumping over the walls of the fortification; and immediately separated into small parties, to appear before every house at the same time, The place was compleatly surprized, and the enemy were entering the houses at the moment the inhabitants had the first suspicion of their approach. The whole village was carried in a few hours, and with very little resistance; one of the garrison 
houses only, being able to hold out against the enemy.

H Aving carried the place, slain forty seven of the inhabitants, captured the rest, and plundered the village, the enemy set it on fire ; and an hour after sun rise on the same day, retreated in great haste. A small party of the English pursued them, and a skirmish ensucd the same day, in which a few were lost on both sides. "The enemy however compleatly succeeded in their enterprize, and returned to Canada on the same route, carrying with them one hundred and twelve of the inhabitants of Deerfield as prisoners of war. 'They were twenty

- five days on their march from Deerfield to Chambly ; and like thicir masters, the savages, depended on hunting for their support. On their arrival in Canada they found much humanity and kindness from the French, and from M. Vaudrieul their governor; but complained much of the intolerance, bigotry, and duplicity of the priests.**

* WITH aprofound reppect to the memory of his worthy grand sire, the tritcr of these sheets cannot omit this opportunity of mentionirg with plcasure his descent, as heing the grand son of the Rev.John Williams, at that time lle minister of Deertield. This worthy man was born at Roxbury, in Massachusets, in the year 1654. He was educated at Harvard College, an took his degree in 168, , and was the first settled minister at Deerfiedd. At that time, when the people were forming a new plantation it was customary to engage some respectable preacher of the gospel, to hezin the settlement with them. Having the best cducation which the cuuntry could give, and being men of sober nicrals, the cleggy had of conscquence grtat infuence in the civil, as well as in the religions concerns of the country: Aad the people generally found in their ninister, not a useless dupe to metaphysical chimeras, but an ahle, a moral, and judicious friend; capable of directing their devotions, and assisting them in the difficulties and hardships, inseparable from their situation, when first commencinz their scttlcment.

Such a onc was the miaister of Deerfield. L.carned, moral, judicinus, and of exemplary piety and gravity, he was greatly amiable, and active. In $\mathrm{I} 697$, the village was attacked by a party of the enemy; the ninister put himself $2 t$ the bead of his people; and with much prudence and 
For several years after this period, a continu. ed scene of devastation and destruction was kept up. The New-England colonies formed several expeditions against the French and Indians, in the eastern parts ; and they, in their turn, were constaitly making inroads on the exposed settlements of the English. Success often attended both parties; but the exertions of the English colonies proved extremely distressing to the inhubitants, as well as their losses. They were too few in nnmber, to bear the loss of men; and so low in their circumstances that

bravery they repulsed the enemy. On the breaking out of a new war, his anxiety and his activity increased: Upon his application, the government scint a gnard of 20 soldiers to Deerfield; and during the whole vinter he was incessant in his religious and civil conduct, to impress the minds of the people with a sense of their danger, and with a spirit of vigilance and activity. When the enemy broke in upon the town, they went to his house in the beginning of the onset; and about twenty of the Indians entered his house, as he was rising from his bed. Such was the firmness of his mind, that he took a pistol from the head of his bed, and presented it to the breast of the first Indian that came up. The pistol missed fire, and the Indians immediateIs disarmed and bound him. "Two of his children, and a negro woman, were butcliered, and his house pillaged. The Indians then suffered him, his wife, and the five surviving children to put on their cloaths, and prepare for their drcadful march.

WHE. the sun was about an hour high, they led bim out with his wife and children, and set fire to his house and barn. On the second day of the journcy, his wife searcely recovered from lying in, informed hin that her strength began to fail. He knew the consequence; her savage master clove her head, and put an end to her life, by onc struke of his hatchet. Mr. Williams himsclf was carried to Canada with his children. At times, they all received favors from their Indian masters, and many acts of kindness from the French. During his captivity, by lis learning, firmness, steadiness, and resolution, he proved of much service in supporting the spirits of his people, and prescrving their attachment to the religion and government of their country. In 1 yo6 he was cxchanged, and sent to Boston, with a number of the English captives. Some of tie best parishes near Boston, urged him to settle with them, as a minister. Declining every ofier and prospect of this nature, in conformity to a vo:"mide in his captivity, he returned to Deerfield; collected his flock, and began again with them the lavors and hardships of anotlicr settlement: and remained sheir worthy and faithful minister till the year 728 ; dying in peace, beloved by his people, and lamented by bis country. The account that he wrote of his captivity, is in the plain serious style of that day; an instructive and entertaiuing relation, and has gone through seven editions.- The memorial of virtue is immortal. It is known with cod and with men. When it is gresent, men satesexample at it; and when it irgone, they dePire it." 
they could scarcely procure the necessaries of life, much less bear the expences of war. The whole country was in a state of constant terror and alarm ; and in the fronticr towns, the women and children found no refuge, but in the garrisons. The men went armed to their work, centinels were posted in the fields, attacks were made almost every week, reports of Trench and Indian armies and incursions were incessant, and every month some of the inhabitants were cut off by the enemy. And what was more humiliating, a favorite but ill managed expedition against the French at Port Royal in Acadiia, in 1707, had failed.**

'To put an end to this horrid scene of depre. dation and slaughter, there was no way but to carry the war to the head quarters of the enemy, and make another attempt for the conquest of Canada. Solicitations for this purpose had been made to the court of England by the assembly of Massachusetts ; by Francis Nicholson, who had been lieutenant governor of New York and Virginia ; and by captain Samuel Vetch, who had been several years before at Quebee, for the redemption of prisoners, and was well aequainted with the river St. Lawrence, and the French settlements. Vetch made a full representation to the British ministry, of the state of things in America; and of the necessity of carrying the war into Canada. The Bristish ministry approved of the plan ; and early in the spring, [1709] Vetch came to Boston with letters from the earl of Sunderland, the British secretary of state,

* Hutchinson's Hist. Massacinzetis, Vol. 2.p. I27-I53. Belknap'3 Ilist. New-Hampshite, Vol, I. 1. 329-m-34\%. 
the governors of the English colonies to engage their assistance.

'Г⿴囗十 $\mathrm{E}$ plan announced by these letters, was, that her Majesty would dispatch a squadron of -ships to Boston, by the midlle of May, with five regiments of regular troops. The colony governments eastward of Connecticut, were re. quired to raise twelve hunrred men; and to furnish them with transports, flat bottomed boats, pilots, and provisions, for three months. With this force it was designed to make an attcmpt upon Qucbec. At the same time fifteen hundred men were to be raised in Connecticut, New York, New Jersey, and the southern colonies. 'This corps was to proceed by way of lake Champlain, and make a descent on the Island of Montreal. Vetch was appointed a colonel, and Nicholson, by the nomination of the guvernor of New York, and the consent of the fovernors of Connecticut and Pennsylvania, was appointed commander in chicf.

Azi the colonies, except Pennsylvania, furnished their quotas of troops. The provincial army from the eastern colonies, was ready to sail for Qucbec by the twentieth of May. Nicholson with his troops marched early in the summer to Wood creek, where he was direcied to wait till the fleet should arrive at Poston. Besides the quotas of troops which were to be raised, several independent companies were formed, and sent on to the army. Six hundred Indians were also collected, and a thousand of their wives and clilidren were maintained at Albany ciuring the campaign. Provisions and stores for the army were collccted

VOL. $\mathrm{x}, \mathrm{P} 2$ 
and transported; and more than one hundred battoes, ind as many birch canoes were con. structed for crossing the lakes. Three forts were built at Wood creek, bisides many blockhouses and stowes for the provisions, which had been provided and transported with great dispatch.

Eveny thing now bore the appearance of success. The public afiuirs of Great Britain were conducied by a wise and able ministry. Their arms had been attended with uncommon success in Flanders, under the celebrated duke of Marlberoughh ; and France was so weakened by her repeated defeats in that country, that she was not in a condition to give assistance to so remote a colony as Canada. The Indians of the five nations, though the address and solicitations of Schuyler, appeared to be heartily engaged in the business. Joy seemed to sparkle in every eye, and the expectation appeared to be universal, that the time was now come, when Canada was to be reduced; and an end put to those horrid scenes of destruction and slaughter, which had so long distressed and wasted the cointry.

THE scene of joy and expectation was not however of a long duration. The armament expected from England did not arrive; nor any intcliigence that it was ready to sail. A great mortality began to picvail ancrig the troops at Wood-creek. With the sickness and disappointment, the public humour and expectation began to change; and the spirit of discontent ard suspicion became apparent, and increasing. The delay of the flect spread a 
general discontent through the country; and carly in the fall, the assembly of New York addressed their commander in chief, to recall their forces from the camp. Nicholson and Vetch put an end to the campaign; and repaired to New Port in Riode Island, to join in at congress of colony governors, to consult what further attempts they should make against the enemy. "Two or three days before this con gress met, on October the eleventh, intelligence was received from England that the British ministry had been obliged to give up the prospect of the Canada expeclition: 'That when the troops were ready to embark, news arrived of the defeat of their allies in Portugai, and that the British ministry had no way to afford them rclief, but to order to their assistance the troops designed for Canada; and that their attention was now who!y diverted from that expedition. Upon the receipt of this news the assembly of Massachusetts desired their governor to disband their men, and dismiss their transports.

Tuus ended the second attempt to reduce Canada. The piun of the crpedition seems to have been well conrerted, but it was not known how many diffuculties would unavcidably attend the progress of an army through Late Cham plain; and how much time it would require. While Nicholson lay at Wood creek, the governor of Canada had intelligence of all his motions : and sent out an army from Montreal of fiftecis hundred French and Indians, to oppose him. The French army set out on the twenty eighth of July, and in three days advanced forty leagnes towards Nicholson's camp. 'The intelligence. 
they received, was, that the English arms? amounted to five thousand; and they concluded; it would be the safest to return to their advanced posts, and receive them there. If Charlevoix, the French historian, is to be credited, the Indians of the five nations, were doubtful, whether the complete success of the English. army would be best for them. Upon the authority of father Mareuil, who had been a prisoner at Albany, he relates that a grand council of Indians was held at Onondago, that one of their old men made a speech in the council, and asked them whether they were not sensible that they were situated between two powerful nations, either of which were able to extirpate their tribes; and would not fail to do it, when either of them. had fully subdued the other. Iie then advised them not to adopt any measures that would tend to destroy their own importance and independence; but to pursue their formerpoincy, and to be at paace or war with either nationy. as should best tend to keep up the contest between them. The speech and policy of the aged Sachem made a great impression on the. assembly ; and according to Mareuil, the Indians were not active in assisting Nicholson, but rather wished to pollute the water from which his army drank, and to impede their progress. But whatever might be the circumstances, an event in Portugal put an end to the whole expedition. And the plan concerted and urged by the British ministry. served no other purpose. than to produce the loss of a great part of Nicholscn's army, to entail a heavy debt on the En. grish colonies, to dishonour then in the view. 
of the French and Indians, and to spread a general discontent and stispicion through the country.**

The attempt upon Canada having failed, the frontiers were again inrolved in blood and destruction. While the preparations were making to invade Canada, the French employed all their arts in managing the Indians who were attached to them, and engaging them in a vigorous opposition; but as soon as the clanger was over, numerous parties were sent out to harrass the English frontiers. These irruptions were chicfly made on the northern and eastern parts of New England. Among others, one of their celebrated partizans, Rouville, with one hundred and eighty French and Indians, made another attempt upon Deerfield. The inhabitants had but lately returned from their captivity, and had not forgot their sufferings. The enemy was: discovered at a distance, the inhabitants rallicd, bravely defencled thenselves, and repuised their assailants.

NEW Yor r had as yet; escaped the Indian desolation and carnage, being covered by the Indians of the five nations; between whom, and the French and Indians of Canada, there was yet subsisting a treaty of friendship and neutrality. Mr. Hunter, the governor of New York, was so apprehensive of danger from some of the confederates, thit he made a voyage to Albany, to renew the treaty that subsisted with those nations. While engaged in this business, he was strongly solicited by the New England govern-

* Snith's Hist. New-York,p. I76. Trumbull's Hist. Cennecticut, P.45\& Hutchirson. Vol. 2.p. I6z.

FOL. I. P 3 
ments to engage the five nations in a war with: the Abenaquies, who were daily ravaging their borders. Attentive chiefly to the interest of the province of which he was governor, he declined the measure, lest it should bring hostilities upon. that province. New York commended this policy as.wise, prudent, and salutary to that province. The New. Fingland governments. condemned it as narpow, partial, and selfish ; and tending to create distrust, danger, and disunion, in the English provinces; and were loud: in their complaints, that their, enemies found at Albany, arms and ammunition to carry on the war aguinst them, and a good market for allthe spoil and plunder that was taken from them. Such however was the importance of vigo. rous measures to preserve the attachment of the five nations, and to defend their own frontiers, that the English colomies still retained the idea of driving the French out of: Canada. The congress of governors which met at Rhode Island, were agreed in the necessity of this meas. ure: ; and Nicholson and Vetch who had met mith them, were fuily in the same sentiment. It was agreed that an address should be made to. queen Anne, representing the great harmony and exertions of the colonies in her. service, the necessity of reclucing the French in North $A$. merica to her government; and praying licr majesty to grant to the colonies an armament, which with their assistance, shoukl be adequatc to the design; and that agents should be sent to Great Britain, to join with Nicholson in representing the state of the country, and soliciting: assistance against Camadil. 


\section{HISTORY OF VERMONT. 315:}

No man at that time had a more extensive: acquaintance with the affairs of the English: colonies than colonel Schuyler of Albany. He fully comprehended the importance of the Indian alliance and trade, the necessity of expel. ling the French from the northern continent, and the danger that arose to the English colo-. nies from the diversity of their interests and governments. His influenoe among the Indians: was much greater than that of any other man : By his. liberality and generosity to their chiefs, he had impaired his own fortune, but acquired: an ascendency that was of much use to his. country. Dissatisfied with the management. and failure of the expedition, impressed with: the necessity of vigorous exertions against the French, he resolved to make a voyage to England at his, own expence; and: to carry. with. him five of the Indian sachems, to give a more sensible impression to his, solicitations. at the British court. 'The asscmbly of New: York: had determined to address the queen on the subject of a Canada expedition; and they availed themselves of Schuyler's intentions, to. express the sense they had of his merits, and: to have their address presented by him.,

SCHUYLE soon embarked from. New York: with the five Indian chiefs, and had a prosperous voyage to England. The manner of his reception, served to display the knowledge and. prudence, with which he had concerted his plan. His five. Indian kings engaged the attention, and gave him admission to all orders, companies, and socielies of men in the kingdom. The lords and commons, the nobility and gentry. 
the clergy, the philosophers; and citizers, alf wanted to see the American Mohawls. The mob followed them, wherever they wont ; and small portraits of them were every where sold in the streets. 'The British court was then in mourning, on account of the death of the prince of Denmark; and it was determined in the cabinet, that the Mohawk kings should appear to mourn as well as the rest. The managers of the play house were to determine upon the forms, and adjust the ceremonies of their dress ; and the queen was to be at the expence. The result was, the five Mohawks came forth arrayed " in black under cloths, after the English manner; but, instead of a blanket, they had each a scarlet ingrain cloth mantle, edged with gold, thrown over all their other garments." "The next part of the business was to adjust the etiquette of the public audience they were to have of her most sacred majesty; and it was conciuded that profound reasons of state required that an extraordinary solemnity should attend this transaction. Sir Charles Cotterel, master of the ceremonies, conducted them in two coaches to St. James's; and the lord chamberlain introduced them to the royal presence. Amiclst this scene of parade and ceremiony, the Indians made a speech to the queen, April the nineteenth, 1710 ; the whole object of which was to persuade her majesty to make another attempt for the conquest of Canada; but tlie specch itself, whether owing to the customs of the British court, to an English composition or correction, to an adjustment to a royal Euro. pean ear and importance, or to any other cause?, 
the speech itself was destitute of the spirit, dig. nity, energy, and independence, with which the Mohawks always, spoke in their own country.*. Тн в speech however had the effect, which. was intended; it proved acceptable to her most. gracious majesty ; and Schuyler had the pleas. ure to see his plan succeed, and the address to. make his five Inclians of more consequence at the court of London, than the whole royal family would have been in the Mohawk country.

Applicatrons were now before the queen. from New Hampshire, Massachusetts, RhodeIsland, Connecticut, New York, and the five. nations, seconded by Nicholson and Vetch, and: many other respectable characters, soliciting for: another expedition against Canada. The Brit-. ish ministry at first seemed inclined to favor. the business, añ encouragement was given thate

- According to Oldmixon s.acoount, the following is a translation of: the Indian address.

"Grat QueEn,

"WE have undertaken a long voyage, which none of our predecessors: sould be prevailed upon to undertake, to see our great queen, and relateto her those things, which we thought abso!utcly necessary, for the good: of her, and us herallies, on the other side of the water.

"WE doubt not but our great queen has been acquainted with our long: and tedious war, in conjunction with her children, against her enemice. the French; and that we have been as a strong. wall for their security, even to the loss of our best men. We were mightily rejoiced, when we heard ourgreat queen had resolved to send an army to reduce Canada, and imraediately, in token of friendship, we hung up the kettlc, and took up the hatchet, and, with one consent, assisted colonel Nicholson in making preparations on this side the lake; but, at length, we were told our grcat. queen, by some important affairs, was prevented in her design, at present, which made us sorrowful, lest the French, who had hitherto dreaded us, should now think us unable to make war against them. The reduction. of Canada is of great weight to our free hunting; so. that if our great queen should not be mindful of us, we must, with our families, forsake the. country, and seek other habitations, or stand, neuter, either of which will: be much against our inclinations.

"IN token of the sincerity of these nations, we do, in their names, present our great queen with these belts of Wampum, and in hopes of our great queen's favor, leave it to her. mzost gracious sonsideration." Smith's: Hist. Newyork, p... I38. 
it would be taken up the next spring. Nicholson came over in July with that expectation, accompanied by a fleet of five or six frigates, with orders to raise recruits in the colonies. They were designed however, not to make an attempt upon Canada, but to effect the reduction of Port Royal, and Nova Scotia. The chief command was given to Nicholson, and he made an easy conquest of the place on the fifth of October. In honor to queen Anne the place was now named Annapolis, and Vetch, who was adjutant general, was appointed by Nicholson to be the governor of the place.

ENCOURAGED by this success, Nicholson in the fall made another voyage to England to urge again the Canada expedition. 'The expectation of the country had been so much disappointed by the measures of the British court, that it was not expected that any assistance would be afforded. The business howcver was resumed, and the ministry feil in with the proposals. $\mathrm{O}_{\mathrm{i}}$ June the eighth, 1711, Nicholson arrived at Boston, with the intelligence that a flect might soon be expected from England ; and with orders that New England, New York, New Jersey, and Pennsylvania, should have the quotas assigned to them in readiness to join the expedition. A general mecting of the governors of the colonies was immediately appointed at New London ; and while they were holding a council upon the subject of their orders, the fleet arrived at Boston but sixteen days after the furst intelligence of the expedition by Nicholson.

THE fleet was not furnished either with pilots or provisions; and in addition to the troops 
and stores required of the colonies, they were called upon to find provisions for the English fleet and army for ten weeks. It must have been known to the British ministry that a compliance with these requisitions was impracticable. The colonies, from the nature and circumstances of the ministerial management, were suspicious that nothing would be effected; and that in such an event, the policy of the British cabinet would be, to lay the blame upon them. Zealous for the expedition, and determined that no fault or biame should attach to them, they made the most vigorous exertions to comply with the requisitions. Troops were raised with the greatest expedition, provisions were procured wherever they could be found. In some of the colonies, a price was fixed for them by the acts of the assemblies; and in others, the owners were compelled to part with them, or to have them seized by the civil authority. The whole country was in motion, to provide for the expedition; and no other business was much attended to, but the raising of troops, and procuring military stores.

So general and spirited had been the exertion of the colonies, that in little more than a month from the arrival of the fleet, the levies and provisions for the colony army, and for the fleet, were compleated; and on the thirticth of July, the whole armament sailed from Boston 'The fleet consisted of fiftcen ships of war, from eighty to thirty six guns, with forty transports, and six store ships; under the command of Sir Hovenden Walker. The army on board eontained seven regiments from the duke of 
Mariborough's troops, and a battalion of $\mathrm{ma}^{\circ}$ rines: two regiments raised in New Hamp. shire, Massachusetts, and Rhode Island, were also embarked. The wholc amounted to near seven thousand men, with a fine train of artillery, and amply provided with the necessary war. like stores, under the command of brigadier general Hill. 'This force was fully competent to the reduction of Quebec; which at that time was not strongly fortified, or in any preparation to withstand a regular siege by a veteran arnyy $O_{N}$ the same day in which the fleet sailed from Boston, Nicholson set out on his journey to Albany; and in a few days appeared at the head of four thousand men. This army was raised in Connecticut, New Yoik, and New Jersey. The Connecticut troops were comman. ded by colonel Whiting, an experienced officer, who had commanded them the year before at Port Royal. The New York and New Jersey troops were commanded by colonels Schuyler, and Ingcidsby ; and Schyyler, with his usual spirit of activity and enterprize, had procured six hundred indians of the five nations, to join the colony troops.

$T_{\text {H }} \mathrm{E}$ enemy in Canada were not unacquainted with these preparations. Vaudrieul, the governor gencral, sent his orders from Montreal to Sieur Beavcourt, to hasten and strengthen the works at Quebec; and commanded all the regular troops and militia to hold themselves in readiness, to march on the first alum or notice. Four or five huidred Indinus of the distant na. tions, were collected at Miontreal. Severai Indians, and two missionaries, were sent anong 
the five nations, to detach them from the English interest. Quebec was fortitied, and put inin the best situation that the time wond admit, to sustain a siege; and all the principal posts below the city, and on both sides of the river, were prepared to oppose the landing of the British troops.

WALKR arrived with the fleet in the mouth of the river St. Isawrence, on the fourceenth of August. Fearful of losing sight of his trans. ports, and the wind fresh at the north west, he put into Gaspe bay ; and continued there till the twentieth. On the twenty second, two days after he left the bay, the fleet appeared to be in great danger; without soundings, without sight of land, surrounded with a thick fog, and the wind high at the south east. In this situation the ships were brought to, with their heads to the southward, in expectation of being driven by the current, into the midst of the channel. Instead of this, about midnight, August the twenty third, the seamen found that they were driven on the north shore, among the rocks and islands, and in extreme danger of being lost. The men of war escaped, but eight transports were wrecked on Egro Island, near the north shore; one thousand of the men perished, and six or seven hundred were saved by the other ships. In this distress but one of the colony vessels was lost, and the men of that were saved; the admiral and gencral were in great danger, but escaped by the vessel's coming to anchor. The next moming the wind came round to W.S. W. the admiral bore away for Span. ish river, and the men of war and transports vol. I. Q2 
followed. The wind came round again to the east, and would have carried them to Quebee in two days ; but instesd of making another at. tempt, they were eight days beating down the river, against an easterly wind, before they arrived at Spanish river in the island of cape Breton. At that place a council of wa: was held, and aiter some fruitless consultations it was unanimously resolved, not to make any further trial to go up the river St. Lawrence, and not to make any attempt against the French at Placentia in Newfoundland; but to return, as soon as they could, to Eingland. On September the sixteenth, the flcet sailed for England, and the American troops and vessels departed for their respective colonies; October the ninth, Waiker arrived at Portsmouth. Here the scene was closed ; in addition to the other misfortunes, on the fifteenth, the admiral's ship the Edgar, of seventy guns, was blown up; having on board? above four hundred men, many other persons who came on board to visit their friends, and most of the admiral's papers.

The army designed to invade Canada by way of lake Champlain, had not advanced far from Albany, before they received intelligence of the disaster which had attended the fiect. Nothing remained for Nicholson, but to disband his army and return. The marquis de Vaudricul had been at Quebec, waiting for the arriral of the English fect. He received intelligence by ile fishermen, and other vessels, that many ships lad beer stove, that much military apparatus, and rany dead bodies with red coats trab been driven on shore, and that the river was 
clear of ships ; and he justly concluded that the English fleet had suffered so much, that they had given up the idea of making any attempt upon Quebec. Immediately he ordered the whole force of Canada towards Montreal, and lake Champlain ; and formed a camp at Chambly of three thousand men, to oppose Nicholson's army, should they attempt to penetrate Canada in that quarter. But he was soon informed that he had nothing to fear from the colony army ; that Nicholson had returned with his troops, upon the news of the disaster which had attended the fleet; and that the people of Albany, instead of being engaged in any hostile attempts against Montreal, were in much anxiety and fear for their own safety.

Such was the issue of the third attempt to effect the reduction of Canada. The two former had served to bring heavy debts upon the colonies, to destroy a number of their young men, to discourage the public confidence and expectation, and to abate the attachment of their Indian allies. This, had not only produced the same effects, but it served to fill the country with jealousy and suspicion of the British ministry ; with severe charges, and loud complaints against their conduct. 'The want of seasonable intelligence and orders, the late arrival of the flect at Boston, the known impossibility of procuring the provisions required without previous notice, the complaints and obstinacy of the ad. miral, the ignorance of the pilots, the secret intentions of the tory ministry, were subjects of angry debate and altercation. The remarks of the whigs in England were still more severe. 
Lord Harley went so fur as to say, in his account of this expedition, that the whole was a contrivance of Bolinbruke, More, and the lord chancellor Harcourt, to cheat the public out of twenty thousand pounds. No public enquiry seens to have been made into the matter. It is more candid to assigin the misfortunes of the flect to error, than to design. But when every allowince is made that candor can admit, it will be extremely dificuit to believe that the British ministry at that time were scriously in earnest, in vishing to carry their conquests any further against Fince.

TuE ill success attending this expedition, gave to the five nations unfivorable sentiments, of the power and policy of the English colonies. Emissaries were among them from the gorernor of Canada, to seduce then from the English, und attach them to the French, the better managed and more successful cause. And yery serious apprehensions were entertained, that they were inclining to the French intesest. The eastern India:ns were encouraged by the failure of the cxperlition, to hamass the fronticrs of Massachusetts and New Hampshire; and much damage iras done the next summer in that part of the country. Dudley, Salstontal and Cranston, the governors of the eastern colonies formed a design to engage the five nations in a rupture with the French, to afford some relief to their frontiers. But neither the governor, the assembly of New Yo:k, or the Indians, appearing to faror the plim, the scheme was dropped;

* Snith's IIist. New York, p. Ifr. Hutchinson's Hist. Massachusetta Ka. 2. P. I80. 'Trumbull's H.ot. Connecticut, p. 405. 
and the eastern colonies defended themselves with good success, against the inroads of the savages.

THE European powers had now become tired of the war. The real interests of the French court, and the factions of the British, inclined them to terms of peace; and on March the thirty first, the treaty of Utrecht was signed, by the plenipotentiaries of Great Britain and France. 'The fifteenth article of this treaty was designed to prevent any further interference of either power to molest, or to influence the Indians to war. The plenipotentiaries seem to have scarcely known whether to call the Indians, allies, friends, or subjects; but the Indians themiselves perfectly well knew, that they did not mean to be in subjection to either of the European powers, or to their colonies; but to preserve their independence, and make the most that they could of their trade, and of their quarrels.

$W_{H E N}$ the news of this treaty became known in America, the Indians every where appeared to be disposed to peace. On the eleventh of July, 1713, the eastern Indians had a treaty with the governors of Massachusetts and New Hampshire, at Casco bay; they renewed their professions of allegiance, engaged to be at peace with the English, and to prevent all hostilities for the future. Though little conficlence could? be placed in such treaties, such had been tite sufferings occasioned by the war, that this agreement with the Indians was considered as a matter of great benefit and joy to all parties; and the country had the prospect of that trans.

VOL. I e 3 
quility, which the people so much nceded and alesired.

$P_{E A C E}$ with the savages however could not be of long duration. The English were constantly extending their settlements to the eastward. "The Indians claimed the lands, and an opposition of interests was constantly producing jealousies and complaints on both sides: the governor of Canada availed himself of so fivorable an oppoitunity to encourage and assist the indian animosity, without appearing to take any avorved part in the business. Insults and ravages soon succeeded, which terminated in burning the property, and captivating the inhabitants in the advanced settlements : And from 1720 to 1725 , a war was carricd on with great riolence between the Indians in the eastorn parts of Canada, and the provinces of Massachusctts and New IIampshire. Few wars have ever been more bloody ordcstructive. But as the crowns of Great Britain and France were then at peace; this war could not be carried on with the open assistance of the French government, and of course dir not become general among the Indian tribes. To prevent such a calamity there rvas a congress of the English governors and commissioners, to renew the ancient friendship with the Indians at Ailbany; and Mr. Burnet, governor of New York, prevailed upon them to send a message to the eastern Indians, threatening them with war, unless they concluded a peace with the English. The Indian war became of course confined to the castem parts, and did not extend to the province of Newyork, or to any of the sctilements in the vicinity of 
lake Champlain ; and was concluded by a treaty with the Indians at Falmouth, in the year 1725. At this period both the English and French were extremely cautious to preserve the friendship of the five nations, as they had lately received a very considerable addition to thoir strength. Above eighty Nicariagas, with their women and children, had repaired to their territories, from the country north of Missilimakinac ; and the whole tribe of Tuscaroras, who possessed a large tract of country near the sources of James' river in Virginia, had also removed and settled near the south east end of the lake Oneida. This event had augmented the Indian importance; and instead of calling themselves the five, they now assumed the name of the six nations; and like the Eurcpean powers, felt the comfort and pride of increased territory, population and power.

From the treaty of Utrecht, a long period succeeded, in which there was peace between the British and French courts. 'Their colonies in America, were now enjoying the benefits of it ; but neitlier of them were inatientive to their $\mathrm{fu}$ ture prospects or interests. A ware of the increasing power of the English colonies, and the threatening aspect which it had on the growth and saffety of their own, the court of France had adopted a regular and systematic plan of conduct and policy. 'Their aim was to seize all the important posts and passes fiom Canada to Loulisiana, to fortify the commanding situitions, and thus to command the Indians, secure their trade and deppendence, and confine the Finglish to a narrow limit along the sea coast, and pre- 
vent their extending any further into the Indiars or inland countries. Mr. Burnet, the intelligent and vigilant governor of New York, well acquainted with the geography of the country, very justly concluded that the most effectual method of counteracting the French pursuits, would be to get the command of lake Ontario. For this purpose, in the year 1722, he began to erect a trading house at Oswego, in the country of the Senecas : and to make it a place of increasing strength, trade, and general resort. Nothing could more naturally excite the jealousy, and alarm the fears of the French, than this proceeding of governor Burnet. An English trading house and fort at the mouth of $\mathrm{O}$. nondago river, could not fail to injure their trade, to introduce the English into the heart of the Indian country, and without a considerable naval force on their part, would give them the command of lake Ontario, and divert the Indians from their customary route and resort to fort Frontenac. Determined at all events to preserve the Indian trade, and the command of lake Ontario, in the year.1726, they launched two vessels in the lake; and transported materials to build a large store house and to repair the fort at Niagara. The French already commanded the entrance into the lake at the east end, by fort Frontenac; if they could now se. cure the navigation by their vessels, and the entrance into the west end of the lake by the fort and trade at Niagara, they would effect their purpose and render Oswego useless to the English, by carrying the Indian trade two hundred miles further to the west. The English and 
French governors exerted themselves on these occasions ; wrote, complained, and sent mes. sengers to each other; tried to enigage their European sovereigns to interfere; flattered, deceived, and made speeches to the Indians, to convince them that all they meant was to promotc their safety, by taking possession of their country : thus murmuring and wondering at the injustice and frandulence of each cther's proceedings, they agreed in the event, to keep firm possession of ail the posts they had established in the Indian territory.

In this kind of enterprise and manouvre, the French generally discovered the most activity and address : and while the attention of New York was taken up with the affairs of the western lakes, the French determined to make nearer approaches to the vicinity of Albany. In pursuance of this plan, in the year 1731, they came up lake Champlein with a considerable force; and immediately began to erect a fort at Crown Point. No measure could have been batter adipted to promote their own interest. It was through lake Champlinin that their troops had marched in their experitions against Schenectadly, the Mohawk's castles, and Deerficld. It was through this lake that their scouting parties found the most easy, and the safest passiagc, in their excursions against the English culonies. In all the attempts of the Inglish to effect the conquest of Canada, the attacks upon Montreal were always contemplated to hare been effected by the waters of lake Champlain. To erect a fortress at the south end of this lake, was to secure the whole navigation of it ; and the com- 
mand of a large portion of the English and In. dian frontier. From this commanding situation the French could not only prevent the attempts of the English to penetrate into their own coun. try, but would always have a magazine of arm and ammunition, to supply their own troops and scouting parties; and an asylum, to which the Indians might readily retreat, from their plundering and scalping expeditions against the English frontiers. And by means of the river Sorel, and the lake, it might always be reinforced in three or four days ; or receive any supplies, without difficulty or danger.

The French garrison was at first placed on the east side of the lake, and the settlement was begun, in what is now the town of Addison. On the western side, a more convenient and safe situation was found; in which the harbour was good, and the fortress would be surrounded by water on three of its sides. On this spot, now called Crown Point, the French erected a fort sufficiently strong to resist ainy force, that could be suddenly, or casily brought against it ; and gave it the name of St. Frederick. The land on which it was erected, properly belonged to the six mations; but was claimed by the government of New York, and had been granted by one of their governors, so early as 1696 , to Dellius, the Dutch minister of Albany. The designs of the French, and the dangerous consequences attending the erection of their new fort, were well understood in the English colonies. The Massachusetts government was not a little alarmed. Mr. Belcher, their governor, gave the first information to the government of 
New York; of the French proceedings. He wrote to Mr. Van Dan, president of their council, on the subject; informed him that the Massachusetts assembly had voted to bear their proportion of the expence of a messenger to Canada, to forbid the works, and urged him to engage the opposition of the six nations. New York, at that time agitated with internal controversies, paid very little attention to the business. On February the fourth, 1732, Van Dam laid Belcher's letter before his council : With a singular weakness and want of spirit, they advised him to write to the commissioners of Indian affairs at Albany, and make inquiry whether the land belonged to the confeclerates or to the river Indians. Their passiveness on this occasion was the more unaccountable, as the British crown at that time supported four independent companies at an annual expence of 75001 . sterling, for the protection of that pro. vince. Thus were the French suffered to ad. vance nearly two hundred miles towards Alba$\mathrm{ny}$; and to erect a fortress, which would enable them in any future war, to make their assaults with safety and success, on the frontiers of New York, Massachusetts, and New Hampshire.**

WhILE the English and French colonies eppeared thus suspicious, and preparing for eaci other, both of them enjoyed the substantial and uninterrupted blessings of peace. The pacific disposition of the European courts that time, and the mutual interests of the colonies, made

- Smith's HAist. Nev Yosid 
all parties carefully avoid the appearance of hostilities. They were enjoying the benefits of mutual trade and commerce, and the Indians were unusualiy pacific; every where appearing more disposed to trade and friendiship, than to hostility and war. Wo the English, this state of peace was peculiarly beneficial; for although the French crenerally exceeded them in the management and activity of a predatory war, the English colonies were far superior in the affairs of agriculture, commerce, forming new settlements, improving the fisheries, and other arts of peace : And they could not but wish for a continuance of that state, which not only contributed to increasing cxtent, population, wealth, and safety ; but was every year giving them the superiority over the French colonies. Sowe persoin began to fatter themselves that the Indians had in fact changed their habits ; and had no hostile events taken place in Europe, it is not improbable that peace would have continued for many years longer in the American colonies.

Ix the year 1740 , the afiairs of commerce had involved the crovrsis of Great Britain and Spain in mutual hostilities. Declarations of war ensued; and in conformity to the Luropean custom and policy, the war spread orer a great part of Europe. France soon became cngraged in it, and a declaration of war ensued between Great Britain and France, March 31, 1744 ; of course, their colories and Indian al. lies were again to be involved in destructive and bloody contests. The scene of both was opened in Nova Scotia; and the French, with 
their usual activity and impetuosity, began the business by invading the island of Canseau; they took the island, burned the houses, destroyed the fishery, and made the garrison and inhabitants, their prisoners.

To savagies, the horrors and plunder of war are so agreeable, that when the flame is once kindled, they delight to increase and expand it : and notwithstanding the long period of peace and friendship; they very readily embraced the opportunity to fall upon the English frontiers. In these incursions, the advantages which the fort and settlement at Crown Point gave to the French and Indians, were soon and severely felt. In the first year of the war, but little damage was done; but in the course of the next year, scouting and ravaging parties of French and Indians every where appeared, and carried destruction and slaughter around the frontiers of the English colonies. Mr. Shirley; governor of Massachusetts, was at that time the most active and enterprising of any governor in the English colonies. His attention was chiefly taken up in the year 1745, in planning and executing the impcrtant and successful expedition against the French settlements in the island of Cape Breton. During that summer, and the next, the Indians in small parties were killing, scalping, and plundering, wherever they could find a defenceless party or family.

THE most advanced fortress at that time in Massachusetts, was a fort at Hoosick, since Williamstown. This fort was erected at the breaking out of the war, to cover the western fiarts of the province from the Indian depreda-

VOE. I.

R 2 
tions, and bore the name of the province. In August 1746, an army of about nine hundred French and Indians set out from Crown Point, under the command of M. de Vaudrieul, to attack this place. They came before it, $\mathrm{Au}$ gust the twentieth. The fort was commanded by colonel Hawks; but thirty three persons were in the garrison, including women and children ; and the fort was not properly provided with ammunition. Hawks defended the place with much fortitude and spirit, but at the end of twenty eight hours, he had expended his powder, and was obliged to propose terms of capitulation. It was agreed that the garrison should be prisoners of war, but that none of them should be delivered to the Indians. 'The day after the capitulation was compleated, Vau. drieul divided the prisoners, and dclivered the one half of them to the Inclians; one of the prisoners being unable to travel, was inmediatcly killed. The French general, when ac. cused of an open violation of the eapitulation, assigned as the reason for his conduct, the state of his army; that they were in danger of a mutiny, the Indians being highly irritited that they were by the capitulation cleprived of their part of the plunder and prisoners. Hawks lost but one man in the siege; and supposed he could have preserved the fort, had he been supplied with ammunition and provisions. From the best accounts that he could procure, the enemy, in those that were slain or died of their wounds, lost forty five of their men in this enterprise.

Mr. SHIRLEY, to the astonishment of all 
Europe, having: succeeded in effecting the conquest of Louisbourg by the New-England troops, was deeply engaged in a plan for the reduction of the French dominions in the northern parts of America. For this purpose in the fall of 1745 , he had written to the British Ministry, soliciting the aid of a fleet and army to attempt the conquest of Quebec, while the colony forces should be engaged in an expedition against Crown Point. The British Ministry agreed to the proposals, and Shirley with his usual spirit of energy and enterprise, engaged all the NewEngland provinces, and New-York in the pro? posed expedition. The provinces, animated by the success at Louisbourg, pursued the bu. siness with great eagerness; their troops were raised early in the season, and thcy waited ali summer, impatient for intelligence and orders from England. In this state of impatience and expectation, the news came that a large flect and army from France, had arrived at NovaScotia, commanded by the duke D'Anville; that it was designed, and powerful enough to recover Louisbourg, take Amnapolis, to break up the settlements on the eastern coast of Mas. sachusetts, and effect the conquest of Boston, and perhaps of. New-York. England was not more alarmed by: the approach of the Spanish armada in 1588, than was Boston, and the other sea ports, on this occasion. Alarm and terror ran through the country, and nothing was to be seen or heard, but preparations to defend the maritime towns, and sea coasts. An uncom. mon series of misfortunes, losses, storms and shipwrecks, destroyed the power, and defeated 
the designs of the French armada; and those. of their ships, that escaped destruction by the storms and seas, returned singly to France, without having made any attempts upon the English colonies. When the alarm occasioned by the French fleet had subsided, and it became known that it was nearly clestroyed, and was at. tempting to return to France, Mr. Shirley's hopes revived that he might still effect something against the enemy: So much was he engaged in the business, that he proposed to. make the attacks upon the enemy in the midst of winter; that the New-Hampshire troops. should proceed by the way of Connecticut river, to the Indian village of St. Francis, and lay it waste; and that the Massachusetts, Connecticut, and New-York troops, at the same time should move on through lake George, and attempt the conquest of Crown Point. Such was Mr. Shiriey's influence at that time, that all the provinces which had raised troops for the expedition, agreed to his proposal of a winter campaign, except Connecticut. To that colony, such an experiment appeared too dangerous and uncertain; and it was owing to their refusal to join in it, that the winter expe. dition was given up.*

$\mathrm{O}_{\mathrm{N}}$ Connecticut river, the most advanced scttlement at that time, was at a place called Number Four, now Charlestown in New. Hampshire. A fort had been built there some years before, which was designed to protect the settlements and forts in the vicinity. From the

* Belknap's Higt. New Hamphire, Vol. 2, p. 2j4. 
commencement of the war șeveral parties of In. dians had appeared at that place ; and at different times had killed, and captivated some of the inhabitants, and frequently destroyed their cattle. In the spring of the year 1747, the enemy made an attempt to take the fort, and destroy the settlement. On the fourth of April, M. Debeline came before it with a large party of French and Indians. It was defended by captain Stevens, an able and judicious officer. The enemy commenced their attack by firing at the fort, on all sides, with their muskets. These making little or no impression, they next attempted to burn the fort by setting fire to the fences, log houses, and other buildings ; and by discharging against it flaming arrows. Having tried these methods for two days without success, they next prepared a wheel carriage, loaded with dry faggots. This machine they pushed before them to set fire to the fort, while it served to protect them from the fire of the garrison. These attempts were defeated by the bravery and prudence of Stevens and his men. Debeline then urged Stevens to surrender the garrison, and be conducted to Montreal as prisoners of war ; threatening to storm the fort and put all to the sword, if this was refused. In answer he was told that the garrison had determined to defend the fort to the last extremity. On the morning of the third day it was proposed, if Stevens would sell them pro. visions they would depart. This also was refused; but Stevens informed them he would give five bushels of corn for any captive, for ivhom they would give an hostage, till they 
could be brought from Canada. On receiving this answer a few guns were fired, and Debeline with his troops withdrew to Crown Point. Sir Charles Knowles, a commodore in the British navy, was then in Boston harbor; and so much did he admire the bravery, and soldier like conduct of Stevens' in defending his fort, that he presented him with a valuable and elegant sword, as a testimony of respect. From this circumstance it was that the town when incorporated by the government received the name of Charlestown.**

DURING the remainder of this war the In. dians were scattered around the frontiers in small parties, and did much damage to the in. habitants; burning their hotses, destroying their cattle, pillaging their property, killing some of the inhabitants, and making captives of others; but there was not any regular expedition undertaken by the French till the treaty of peace at Aix la Chapelle of October the seventh, 174.8, put an end to the war, between the English and French colonies. But it was not till the next year, that the Indians ceased from their hostilities.

- Belknap's Hist. New Hanupsbire, Vol.2. p. 251. 


\section{WISTORY OF VERMONT.}

\section{CHAPTER XI.}

$W_{A R}$. From the year 1750 to 1757. Confer. cinces at Paris. Measures of the French. Embassy and defeat of Washington. Viervs of the English and French colonies. Congress, and plan of union at Albany. Council of generals and governors at Alexandria. Expedition and defeat of Braddock. Success of Monckton and Winslow in Nova Scotia: Proposed expedition to Niagara. Proceed. ings of baron Dicskau at lake Champlain. Victory of Jolnnson at lake George. Termina. tion of the campaizns of 1755 . Military arrangements of the British ministry in 1756. Capture of Oswego by Montcalm. Inactivity of the earl of London.

1752. BY the treaty of Aix la Chappelle, the controversy between the British and French crowns relative to their claims in A: merica was referred to commissioners to be ap. pointed by the two sovereigns for that purpose. These commissioners met at Paris in the year 1752, of which Mr. Shirley, governor of Mas. sachusetts, was one. They laboured much to' establish the claims of their respective sovereigns by virtue of ancient grants, maps, treaties, priority of discovery, ceremonies of taking possession, concessions, and such other grounds of clain, as were then customary among sovereigns; and were supposed to be matters of real weight and importance. The commissioners were not able to come to any agreement; and 


\section{NATURAL AND CIVIL}

no other advantage resulted from their labors and controversies, than a well written account of their conferences, containing much historical and geographical informatiois.

1753. In the mean time the settlers in the English and French colonies, were making nearer approaches to each other; and their rulers were anxious on both sides to seize the most favorable situations and passes for new forts and trading houses. These interferences of the colonists took place the most in the provinces of Nova.Scotia, New-York; and Virginia. In these encroachments the French generally discovered the most foresight, vigilance, and activity. They surprised Logstown, which the Virginians had built upon the Ohio ; made themselves masters of the block-house, and truck-house, with the stores of twenty thousand pounds value, and destroyed the British traders: An officer, with a large force carne down the Ohio, and reduced a fort, which the Virginians had built on the forks of the Monongehala. The marquis Du Quesne was at that time invested with the chief command in New-France. Of an active and enterprising genius; in the year 1753, he began a fort and settlement on the banks of the Ohio, at the place from whence he had driven the English, now called Pittsburgh; designed to secure a station on that beautiful and extensive river; which should cngross the trade, and command the Indians in the adjacent parts of the country. 'The governor of Virginia, Mr. Dinwiddie, was alarmed at so near approach of the French to the settlements in that province. On October the thirty first 
he wrote to the commander of the French troops, complaining of sundry acts of hostility ; and desiring to be informed, by what authority, the French troops had taken possession of a territory belonging to his master, the king of Great Britain.

Ir was on this occasion that the name of GEORGE WASHINGTON was first announced to the world. Governor Dinwiddie gave him a major's commission, and appointed him to be the bearer of his letter to the commander of the French troops. In the winter, and through a scene of much suffering and danger, major Washington executed the business of his commission with that intrepid, determined, persevering spirit, which, since that period, has so much engaged the attention and applause of his country, and of the world. M. Legardeur de St. Pierre, commander of the French troops on the Ohio, returned an answer, December the fifth, full of spirit and resolution, declaring the country to belong to the French king; and announcing his determination to obey his orders, preserve his post, and retain a situation so favorable to defence and strength.

1754. Convinced by the spirited and re. solute answer of the French commander that further encroachments were to be expected, the governor and general assembly of Virginia determined to make a serious opjosition to the French establishments on the Ohio. In February 1754, the assembly voted to raise three hundred men, for the protection of their frontiers. Washington at that time was a young gentleman of twenty two years of age. Hife

$$
\text { VOL. I. } S 2
$$


conduct, in the embassy to the French commander, had proved highly satisfactory to the governor and council; and he was now appointed lieutenant colonel, and the command of the troops was assigned to him. In addition to the men raised in Virginia, two independent companies of foot were ordered by the king to march from New-York to the frontiers of Virginia and Pennsylvania.

$\mathrm{O}_{N}$ April the third, Washington set out from Alcxandria at the head of a little army of one hundred and sixty seven men. On May the twenty eighth, they had a skirmish with an advanced party of the French; of which nine were killed, with $\mathbf{M}$. de Jumonville theír commander, and twenty one were taken prisoners. A reverse of fortune soon took place : While Washington was waiting with about three hundred men for a reinforcement, he received intelligence that the French were advancing with a body of nine hundred men, and two hundred Indians. On July the third he was attacked by a force greatly superior to his own, under the command of De Villier ; and after a resist. ance of three hours, found it necessary to sub. mit to the superior force of the enemy. 'The terms that wcre offered to him were of an hu. miliating nature, but he was no longer in a situation to refuse the demands of the enemy, and was obliged to capitulate. In this engagement the English had thirty killed, and fifty wounded. De Villier reported his loss to be but two Frenchmen, and one Indian killed, and seventeen wounded; and boasted that by making ase of the French language, the terms of the 
capitulation were so expressed, as to make the English acknowledge that they had committed murder in the case and camp of his brother Jumonville; and that the favors manifested to them in the capitulation, were designed to show how much they desired to treat them as friends. Hostilities being thus commenced, and some of the Indians slain, it was known that in conformity to what had always been the maxims and customs of the savages, the other tribes would immediately engage, and an Indian war would commence from one end of the British colonies to the other. And before the summer was ended, the Indians all round the frontiers from Virginia to the province of Maine, appeared to be in arms, and began their attacks upon the English.

Such was the commencement of war in 1754 ; a war, in which all Europe was soon to be involved; and by which, the empire and destinies of North America were to be decided. The French, with a policy superior to the English, had for several years been pursuing an uniform and systematic plan of colonization. Their scttlements in Canada and Louisiana were at a great distance from each other. By means of the lakes," and the rivers St. Lawrence and Mississippi, they had found situations by which these settlements might be connected by a chain of posts and forts. The plan they were execalting, was to take possession of all the comman. ding situations from one colony to the other; to erect forts and trading houses, not far from each other; and thus to command the trade, exclude the English from the Indian country, 


\section{\$44 NATURAL AND CIVIL}

commerce, and alliance, and confine them to 2 narrow limit along the sea coast, and prevent their extending any further to the westward. The English colonies saw their policy, and were alarined with the measures they were so inces. santly and zealously pursuing; and determined to employ their superior numbers and power, to oppose the French proceedings; and to effect some plan to produce a greater uniformity in their councils and measures. Both parties had long been in the habit of trying to engage the Indian tirbes in their quarrels, and to in'flame the savage vengeance against their opposers. 'They had now approached so near to each other ill their settlements, that a constant interference of viers, interests and situations, could not fail to make their commerce precarious, and their neighborhood full of animosity and danger. As peace could no longer be expected between the English and Fiench colonies, the period seemed to be now come in which the grand contest must take p'ace, which of the countries should be subdued; and whether France or England for the future, should have the empire of North America. And all paries. now set themselves very seriously to prepare for the exertion of all their powers and strength.

Til e first step necessary for the English colonies, was to agrec upon some plan of Union, for their mutual protection and operations. The British secretary of state wrote to the governors of the colonies, urging such a measure, and a favorable opportunity now presented to make the attempt. A Congress of Commissioners from the colonies had been appointed at Albany, 


\section{HISTORY OF VERMONT. 345}

for the purpose of holding a conference with the six nations, and to consult on measures for the general interest and, welfare. Governor Shirley proposed to the several governors, that their commissioners should be instructed on the sub. ject of an Union among the colonies.

ON the fourteenth of June, the commissioners assembled, and on the eighteenth, the Congress was opened. It consisted of delégates from New-Hampshire, Massachusetts, Rhode-Island, Connecticut, New-York, Pennsylvania, and Maryland. They agreed to take their places in géographical order, beginning at the north ; and having adjusted their ceremonies and rulcs of proceeding, on the twenty ninth they were ready to treat with the Indians, who had been assem. bled for that purpose. The ceremonies and formality that generally attend an Indian treaty, render it a matter both of curiosity and instruc. tion. The arrangement that was adopted on this occasion, rvas designed to give importance to the transaction. Mr. De Lancey, lieutenant governor, and at that time commander in chief of New-York, within whose territory the lands of the six nations chiefly lay, was appointed speaker to address the Indians. On his right: hand were the commissioners from the colonies; on his left hand, were the council of New-York, officers, and citizens of rank and respectability. In the front were the Sachems and chiefs of the six nations, attended by many of their tribes arranged in a circular form, and preserving a solemn silence. The speech turned on the customary topics, how much the French injured and abused, and how much the English loved 
and benefitted them; and that they now valued their friendship in the highest degree, and should probably soon want their assistance to conquer and extirpate the Frencin. To give wreight to their eloquence, and to make more effectual impressions on the savage mind, a val. uable present was made to the Indians by order of the British king; and several of the colony governments, on this occasion followed the example of their sovereign, and endeavored by their donations to secure the Indian friendship and forbearance to their particular provinces. At no time had the presents made to the Indians amounted to so large a sum, and no art or address was spared to secure their friendship. Whe Indians perfectly well understood the business, and were well pleased with the presents, and with the attention that the British king and colonies had paid to them. 'Their answer was expressive of gratitude, and of a sense of their own importance ; and they very plainly told the commissioners, that the English were not enough attentive to their busincss and interest: That in the last war they lad deserted some of their own forts; that their frontier city, Albany, was almost in a defenceless state; and that the French managed the business of fortifying and maintaining their garrisons, much better than the English had done.

THE treaty with the Indians being finished, the next business of the commissioners was to form some plan of general union, and defence for all the colonies. The commissioners were a mong the first men in the colonies for rank, a. biities, fortunc, and influence. Instead of 
sontemplating any such everits as a contest with Great Britain, or an American Independence, the question was how to establish such an union and government among the colonics, as should prevent their destruction and conquest by the French. One member from each colony was appointed for this purpose; Atkinson of New-Hampshire, Hatchinson of Massachusetts, Hopkins of Rhode-Island, Pitkin of Connecticut, Smith of New-York, Franklin of Pennsyliania, and Tasker of Maryland. In adjusting a plan of union and defence, different political sentiments were found to prevail. Some were fearful of throwing too much power into the hands of the kirig, and others were as much afraid of giving too much power to the colonies. Alarned however on all sides with the increasing power and policy of France, they were extremely cautious not to break on these points, and in a few days agreéd upon a result. "Their plan was, that application should be made to the parliament of Great Britain for an act to constitute a Grand Legislative Council in the colonies. This council was to consist of dele. gates from the several Legislative assemblies, subject to the controul of a president generat, to be appointed by the cromn, and to have $a$ negative roice. This council were to enact general laws; appertion the quotas of men and money, to be raised by each colony; determine the building of forts; regulate the operation of armies; and concert all measures for the com. mon protection and intercst. The delegates of Connecticut alone entered their dissent, and their objection was against the negative voice assigned to the crown. 
WIIH the plan of union and defence, a very just representation was made to the king, of the state and dinger of the American colonies; and copies of both were laid before the several as. semblies. But the plan of American union and defence had the singular fortune of being rejected, both by the mother country, and by the colonies : By Great Britain, because it assigned too many, and too important powers to the provincial assemblies; and by the assemblies, be. cause it assigned such extensive and important powers to the sovereign, and his ministers. Thus at the very time when the fears and ap. prehensions of Great Britain, and her American colonies, were at an unusual height, both were fearful of the consequences of nerw arrangements; and endeavored with singular caution to guard against any questions, that might arise respecting the prerogatives of the king, or the liberties of the colonies. The plan of American union was agreed to on the fourth day of July 1754; but not a single member of the congress that drew it up, had an idea that they were engaged in a plan, which it was in the destinies of mature and providence to compleat, in the course of twenty two years from that day. *

W Ir Ite these measures were going on at Albany, Mr. Shirley was employed in securing the eastern parts of Massachusetts; and buiit the forts of Richmond and Western, to protect the inhabitants, and check the Indians, in that part of the country. Nor was the court of Great Britain inattentive to Anerican matter:

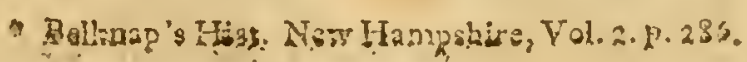


On November the triventy fifth, major general Braddock was appointed general and commander in chief of all the troops which were to be sent to, or raised in North America ; and was ordered to repair to Virginia with two Irish regiments, and to be ready for the military operations of the next spring.

1755. Intent on prosecuting the war with vigor, in the beginning of the year 1755, Mr. Shirley convened the assembly of Massachusetts, and communicated to them the plan that he had formed for reducing fort Frederick at Crown Point, the ensuing spring; and his intention to appoint colonel Johnson of NewYork to the command. The assembly readily concurred in the measures proposed by the governor; and voted to raise their quota of the troops. The plan being thus adopted by Massachusetts, commissioners were sent to the neighboring governments stating the assistance that was desired of them, and requesting their concurrence and aid. Thus were the NewEngland provinces, New-York, and New-Jersey, all put in motion for a vigorous expedition against the French.

While Shirley was thus moring all the northern provinces, Braddock arrived at Williamstown in Virginia, February the twentieth, wittr two Irish regiments. Expresses were immediately sent to the governors of the colonies to meet him at Alexandria on the thirteenth of April, for a consultation on the state of American affairs, and the business of the approaching canpaign. The convention met as was proposed, and the next day entered upon the business

$$
\text { YI. I. T2 }
$$


of the ensuing season. At this convention the governors of Virginia, Maryland, Pennsylvania, New-York, and Mssachusetts attended ; with colonel Johnson, commissioner of Indian affairs. It was found that Braddock had positive orders, to proceed himself with the greatest expedition, to reduce the French fort Du Quesne, on the Ohio. Nothing more was therefore in his power, than to settle some general arrangements for the campaign with the convention; and to leave the execution to others, as he was himself very little acquainted with the state of things in A. merica. *

A t this convention it was concluded that four expeditions should be carried on against the French in the course of the summer. One against fort Du Quesne, under the command of Braddock. Another was to be against Niagara, under the direction of Shirley. A third against Crown Point, under the command of Johnson ; and a fourth against the French forts and settlements in the bay of Fundy and Nova Scotia; to be commanded by colonel Monckton, a British officer, but to be executed chiefly by New England troops under the command of colonel Winslow. The plan of operations for the campaign being thus adjusted, the convention dissolved; and Braddock, Shirley, Johnson and Monckton prepared themselves for the expeditions, of which they were to take the immediate command.

BRADDOC $\mathrm{K}$ was a major general in the British army; a man of undoubted courage, and

- Review of military cperations in North Ameriea, p. Io. Sapposed to be wrote by Mr. Srith of New York. 
expert in all the punctilios of a review, having been brought up in the English guards. In his manners he was haughty, positive and difficult of access. Though well acquainted with the European method of war, he had no idea of the service in a country thinly inhabited and every where abounding with woods, mountains, rivers, morasses, and dangerous defiles. And so attached was he to the European customs of regular discipline and order, that he despised his provincial and Indian auxiliaries; and treated with contempt the advice of those, who endeav ored to give him information of the Indian methods of attack; and to warn him of the danger of ambush, and surprise. On the twentieth of April, he set out with an army of twenty two hundred men, from Alexandria; and after the most extreme difficulties and exertions, arrived on the ninth of July, at the river Monongahala. Having passed the river about noon, he was within seven miles of fort Du Quesne, the object of his hopes and wishes. Marching on in perfect security, and with the most confident expectation of vietory and fame, in an instant his army was alarmed with the Indian yell; and attacked on every side, by a concealed party of French and Indians. Braddock exerted himself with much courage in the manner of an European battle ; but the European discipline, artillery, and arms, availed him nothing. He neither knew where his enemy was, or how to oppose their arts and methods of war: Having exerted himself to the utmost, and to no manner of purpose, he himself and the greater part of his army were slain, by a party of about four 
hendred Indians, placed in ambush, safe frora his arms, and almost concealed from bis sight. Thus despising his American friends and cncmies, the British general fell a sacrifice to the superior knowle?ge and arts of the American Indians : And it was owing to the bravery and prudence of colonel Washington, that a retreat was effected ; and the remaining part of the army rescued from destruction. In this battle scarcely any of the enemy were slain, but the loss of the English amounted to seven hundred men. 'The defeat was total, and the carnage incommonly great; of eighty five officers, sixty four were shain or dangerously rwounded. All the artillery, ammunition, and baggage of the army were left to the enemy; and among the rest, the general's cabinet, containing all hisorders, letters, and instructions. The French. court published the whole of these papers ; and in their printed memorials and manifestoes, an. vowed to ail Europe that they had now compleat information of the designs of Great Britain and he colcnies.

The army that was sent to Nova Scotia, was. put uncer the immediate command of colonel. Monckton, a Pritish officer. Colonel Lawrence, the lieutenant governor and commander in that province, had found it impossible to mise the recruits which he wanted, in Nova Scotia. His attention was tumed to Ner England, as the only place in which he could expect success. With that view, colonel Monckton had made a voyage to Boston, in the latter part of winter, and consulted Shirley upon the business. Such was the reiuctance of the New? 


\section{HISTORY OF VERMONT.' ' 353}

England people to enhist under British officers, that they found it impossible to engage men to serve in the British regiments, or under British officers. It was proposed as the only expedient, that bore the appearance of success, to procure some of the New England officers, who had served in the former wars, to engage in the business. Colonel Winsiow, of Marshfield, was at that time reputed to be one of the bravest and most experienced of the provincial officers. He had been an officer in the expedition to Carthagena, under gencral Wentworth; and had much of the military genius and spirit, which had distinguished his family in the Indian wars of the colonies. It was concluded that if he would erigage in the business, the men might be raised with ease and expedition. Monck. ton visited and consulted Winslow upon the business. Winslow was pleased with the prospect, but wished to have the command of the troops himself. Monchion was extremely anxious to procure the men, but could not think of giving the command to Winslow. After several attempts to compromise the matter, they came to this agreement, that Winslow should have the command of all the men that should be raised in the New England provinces, and be equal at all times in command to Monckton, but only in time of action ; on which occasion, the command of the whole should be in Monckton, who was to be considered as the senior officer.* This point being adjusted, Winslow was commissioned by governor Shirley, and

* Winstow's relation io the auther in IjGiq. 


\section{NATURAL AND CIVIL}

heartily engaged in the business. A regiment was soon raised and sent on to Nova Scotia. Success attended the operations of the British and provincial troops. On their arrival at the river Massaquash, the provincials attacked and dispersed four hundred and fifty of the enemy who were posted there, and took their block house and brest works. On Iune the twelfth, they invested the fort Beau-Sejour, and in four days obliged it to submit. The next day they took the fort at bay Verte, with a large quantity of stores and provisions; and disarmed the Acadians to the number of fifteen thousand. Captain Rous, with three frigates, sailed to the mouth of St. John's river; the French abandoned their fort, burst their cannon, blew up their magazine, and deserted the place. The English had but twenty men killed, and about as many wounded in the whole of this expedition. It served to preserve Nova Scotia, to destroy the French power in that part of Ameri$\mathrm{ca}$, and to raise the reputation and military character of the provincials.

AFTER the death of Braddock, the command of all the forces in North America devolved on Shirley, who had now a comnission giving hin the rank of major general. As soon as the council at Alexandria was finished, Shirley repaired to Boston; and made the most vigorous exertions to compleat and hasten the troops, which were designed to be under the command of colonel Johnson, and that were to go with colonel Winslow to Nova Scotia ; and also to raise a number of batteau men, for the expedition to Niagara. Finbarrassed with so many 


\section{HISTORY OF VERMONT.}

ares, and such a variety of business, with his utmost exertions he could not reach Albany till the second week in July. Oswego, $b_{y}$ the route which was usual at that time, was estimated to be nearly three hundred miles west of Albany. 'The passage was partly by land, but chiefly by' water, upon the Mohawk and Onon. daga rivers; and at every season of the year was both difficult and dangerous. A large number of batteaux had been prepared for the conveyance of the troops, stores and provisions. Whe fort at Oswego was of but litule strength and much out of repair. It was formerly garrisoned by twenty five men; but on the com. mencement of the late controversies, the garrison was augmented to fifty men. Early in the spring, another company of fifty men had been ordered to that station; and in the latter end of May, captain Broadstieet arrived with two hundred more, and a number of workmen. Schuyler's regiment from New Jersey had embarked for that place, the beginning of July; and Shir ley's and Peppereil's regiments were preparing to follow.

A $T$ this time the news arrived of Braddock's defeat; and was announced in terms more horrid, awful and alarming than were just. The reports had an unhappy effect on the spirits and conduct of the English troops. Suspecting and dreading another Indian massacre, some deserted; and of the batteau men, not a few left the service. The Indians of the six nations appear. ed to be clisinclined to hostilities; and were un. willing that the operations of the rar should be sarried into the western country; which they 
wished should remain in a state of tranquility; and be considered as a place of trade and commerce. Nor could any of them be persuaded to join the British troops, in their passage through their country. Embarrassed with such difficulties, it was not till the twenty first of August that Shirley arrived himself at Oswego. He had scarcely one half of the batteau men which had been engaged for the service; and on that account, the transportation of provisions had been so retarded, that he was in no condition to move his army from Oswego.

A LARGE convoy with provisions being expected every hour, on September the eighteenth the gencral called a council of war, and communicated to them the intelligence he had procured relating to the French forts and forces at Niagara, and Frontenac; with an account of his own force and situation. He informed them that the number of effective men in his three regiments, and independent companies, amounted to thireen hundred and seventy six; and that the irregulars, consisting of men from Abany and the Indians, were only to the number of one hundred and twenty. At the same time lie annonnced to the council that as soon as the expected convoy should arrive, it was his intention to embirk for Niagara with six hundred regular troops, the Nibany irregulars, and Indians, with the necessury artillery; leaving behind seven lundred of his troops to preserve the camp and stores at Oswego. The council were of opinton that the expedition to Niagara was adrisuble; and that the worles of Osinego ought to be enlared and strengthened 
and that a greater naval force should be provided on lake Ontario. With his usual spirit of activity, Shirley was deeply engaged in his preparations, when the weather became uncommonly tempestuous and rainy; and continued thus for thirteen days. His troops became sickly ; and the Indians and others acquainted with the climate, pronounced the season too far advanced, to admit of such an expedition upon lake Ontario.

Dou в т т $\mathrm{L}$ as to suceess against Niagara, and anxious for the safety of Oswego, on September the twenty seventh, the general called an: other council of war. He represented to his officers what further intelligence he had received of the state of the enemy, the quantity of his own provisions, and that the numbers in his camp now amounted to two thousand men..... 'The council were unanimous in their opinion that it was not advisable to proceed on the expedition to Niagara that fall, but to defer the matter to the next spring : and that in the mean time, the works at Oswego should be repaired and strengthened; and that a new fort should be ereeted, and compleated as soon as possible. In conformity to the advice of his council the general gave up the prospect of an expedition to Niagara, till the next spring; and spent the renainder of the séason, in repairing and erect. ing forts at Oswego ; and in strengthering the English interest with the Indian nations ; several of whom, disgusted with the Enghish meth: ods of procecting, were become warering in their attachment to the English, and very doubt.. ful of their success. It has iscen customary to

$$
\text { VQL. I U } 2
$$


censure general Shirley for inactivity and delay in prosecuting the expedition to Niagara. In tle state the country was then in, it was inpossible to compleat such an expecition in the course of one campaign. The nilitary services in which he had been cngeged in the conrse of the year, were prosccuted with all the activity and prudence the nature of the sewrice would admit... Few men coubl have dene nore, and probably not one man in America at that time, could have effected so much. When the winter mas approaching, he made the necessary arrngements for the defence. of the place; gave the command to colonel Mercer, with a garrison of seven hundred men, with orders to continue the works; and on October the trenty fourh set out on a journcy to Albany and New-York, to concert measures for the nert campaign.

TIIE capedition against Crown Point had been put under the command of colonel Wil. liam Johnson. 'This offucer was a native of Ireland and had lived several years in the Moliawk country. There he had a fortified seat which he called Mount Johnson, near one of the Mo- " hawk castles, and about thirty six miles from Albany. He was well acquainted with the Indian temper and character, had gaincd the affections, and was become the principal confident of the six nations; on account of his influence over them, Braddock had cntrusted him with fifty thousand pounds stering to engage their friendship and assistance, in the approaching campaign. Next to him, was general Lyman of Connecticut ; of a military teirn, and good abilities. The provincial troops to the nunber 
of five or six thousand men had assembled a Albany and were in danger of beconing disorderly by their inactivity and want of employment. Lyman moved on with his troops to the carrying place, about sixty miles from Alban, and began a fort on the east side of IIudson's river, which is now called fort Edward; and meant to remain at that place till Johnson'should arrive, with the artillery. It was not till the 10th of August that Johnson could set out with his ariilery from Albany; and about the latte end of that month, he proceeded from fort Edward, fifteen miles more northerly; and formed lis camp at the south end of lake George, which before that time had been called lake St. Sacrament, the name that Champlain had assigned to it.

Soon after he had formed his encampment, he received information by his Indian scouts that a large party of French and Indians had taken possession of Ticonderoga, an isthmus which commands the passage between the lakes George and Champlain ; but that no works had been erected. Johnson was informed of the im. portance of that post; and wrote to Shirley, September the first, that he was impatient to get up his batteaux \& artillery; and proposed to move on with part of his army, dispossess the French and secure the post to himself....-The French however had secured the possession, and soon erected works sufficiently strong; to defend it against surprise, or an easy conquest.

The court of France, aware that a war was commencing in North America, had early in the spring dispatched a body of troops to the 
amount of four thousand men, for the defence of their northern colonies. These troops sailed from Brest early in the spring, with a large quan. tity of warlike stores, and a fleet of twenty five sail of the line. Eight companies of these troops had been captured, with two French men of war, off the banks of Newfoundlind, by the British fleet under the command of admiral Boscawen. One thousand were landed at Louisburg, for the defence of that place. The re. mainder arrived at Quebec, with M. de Vaudrieul, governor general of Canada, and barron Dieskau, commander in chief of the troops. The French court wished to reduce Oswego, and thus secure the command of the lakes. With this view Dieskau pushed up to Montreal; from whence, he detached seven hundred of his troops up the river, to fort Frontenac; intending to join them himself with the remainder, as soon as circumstances would permit. Just before the had compleated his preparations, Montreal was alarmed with accounts that an English army was assembled near the lake St. Sacrament ; which was represented as being numerous, and designed to effect the conquest of Crown Point, and then penetrate into the country torvards Montreal. A council of war was callcd on the occasion, and Dieskau was urged to omit the expedition against Oswego, and procecd to Cromn Point, for the defence of the forts in that part of the country against the attempts of the English army. It was not without much persuasion and reluctance that the baron consented to alter the plan of his operations, and procecd to fort St. Frederick. 
WHEN he arrived at Crown Point, he found that there was no prospect that the Inglish ar. my would soon make an attcmpt against that place. Littie acquainted. with an American war, he concluded to march on with his troops, and attack the English in their camp; and if successful to make further attempts upon their northern settlements, Albany or Schenectady, as should be found practicable. In this way, he was not without hopes to bring about the reduction of Oswego, by cutting off the communication between that fortress, and the set. tlements in New. York, from which they must be supplied with provisions. With these hopes and expectations, Dieskau embarked at Crown Point with eighteen hundred men, in batteaux, and landed them at South Bay, now called Westfield. By an English prisoner, the baron received information that fort Edward was al. most defenceless; and that the English camp at the lake, was vithout either entrenchments or cannon. He fixed upon fort Eciward, as the place for attack ; and marched on till he came within three or four miles of the place. There he made known his designs to his army. It consisted of two hundred regulars, eight hundred militia, and seven or eight hundred Indians. The general informed them, that the enterprise would certainly succeed; and that by reducing fort Edward, the English army at the lake must necessarily abandon their camp. and disperse in confusion, in any direction in which they could escape: Then the consequence would probably be that Albany would also fall, and Oswego be subdued by the wat 
of supplies and provisions. The Canadians and Indians were not persuaded that all these effects were about to take place; they were fearful of the effects of camon, and were averse to making an assault upon fort Edward on that account: But discovered a readiness to attack the camp at the lake, where they expected no other arms would be employed against them but musquets. Dieskau was obliged to comply with the inclinations of his troops, and abandoning his principal design, he changed his route, and put his army in motion against the main body of the English at the lake.

IT was not till the enemy had departed from South Bay, that general Johnson had any intelligence of their appronch or designs; and the first information he had, was, that a lurge army of French and Indians had left South Bay, and were actually on their march to fort Edwart. On receiving this information from some of his Indian scouts, he dispatched separate messen. gers to the commander at fort Edward, with advice of the encmy's approach ; and with orders to withdraw ail the troops within the works which had been thrown up at that piace. One of the messengers was intercepted and slain : The other got back s.bout twelve that night, and reported that he saw the enemy about four miles to the northward of the fort. The next morning Johnson called a council of war, who resulved that one thousand inen should be detached, with a number of Indians, "to catch the enemy" in their retreat, either as victors, or as defented in their designs." "This detachment was put.

* joinson'sprinted rettr. 
ander the command of colonel Williams, a brave and judicious officer; and was attended by more than two hundred Indians.

TEE camp of the colony troops was on the banks of lake George, and was covered on both sides with a swamp of thick wood. Upon the cieparture of the detachment a kind of breast work was thrown up, of some trees which were cut down for that purpose; and some of the cannon, which were received a day or two be. fore, were hauled up to strengthen the front. Colonel Williams met the enemy within four miles of the Engilish camp : In about an hour after his departure, a heavy fire was heard which was judged to be within three or four miles of the camp. Johnson judged that his detachment was attacked, and was retreating to. the camp. He immediately beat to arms, and made the best preparation he could for the reception of the enemy. The fire approaching nearer, lieutenant colonel Cole was sent out with a party of three hundred men to cover the retreat. About ten o'clock some of the Prorincials and Indians appeared, running back to the camp; and brought information, that the detachment was attacked on all sicles, and was retreating: In a short time the whole party that escaped, returned in large bodies to the camp. Colinel Williams was slain in the action; the command had devolved on lieutenant col. Whiting, a Connceticut officer, who had acquired much reputation at the reduction of Louisburgh in the former war; and conducted with much bravery and prudence oin the present occasion. Jon s ox manned his breast work, and made 


\section{NATURAL ANB CIVIL}

the best preparation for the reception of the ert . emy, that time and circamstances would permit. At half after eleven, the eneiny were seen to approach. 'Their army was drawn up, and marched along the road, in a very regular manner; aiming directly at the center of the encampment. When they had approached within one hundred and fifty yards of the breast work, they made a halt for a short time ; their regular troops preparing for the grand or center attack, and the Canadians and Indians filing off to the flanks. The regular troops began the engagement with platoon firings, which on account of the distance, and breast work, had little or no effect. 'The artillery immediately began to play upon the eneny; to avoid which, their militia and Indians betook themselves to the trees and swamps, and kept up an irregular fire upon the flanks. The engagement was now become general with both armies, but it was without much impetuosity on either side. The regular troops in the French army preserved their ground and order, for some time, with much steadiness and resolution; but found themselves abandoned by the Canadians and Inclians, and suffered severely by the warm and constant fire from the breast work. Unable to make an impression on the center, they moved to the right, and attacked the regiments of colonel Ruggles, Williams, and rifeomb. Whese regiments received the attac with firmens, and kept up a constant and well directed firc upon the enemy. This attemst upon the right, continued about an hour, without the appenince of success. Dieskau now form! that he conld not make any 
impression on Johnson's army, with his small body of regulars; and that the fire, from every part of his army, was become weak, and decreasing. 'To save the remainder of his troops he attempted to retreat, but it was in much confusion and disorder. Upon this manœurre, a party from the English camp jumped over the breast work, fell upon his rear, and dispersed the soldici's that were about him: Being wounded in the leg, Dieskau could not travel himself : and was found by the party from the breast work; resting on the stump of a tree, abandoned by his men, destitute of any assistance, and unable to walk. A provincial soldier approaching him, the baron was feeling for his watch to present to him: The soldier believing he was in search of a pocket pistol; discharged his musket and gave him a dangerous wound in his hips.

URON their retreat, the enemy halted about four miles from the provincial camp; at the place where the engagement began in the mor. ning with colonel Williams. A party consisting of two hundred, men had been detached from fort Edward; to assist the main body of the army under Johnson. This party was com: manded by captain M'Ginnes from New Hampshire, a brave and active officer. He fell upon the enemy, with an impetuosity and spirit, that soon put an end to their order and consultations. They kept up their resistance for nearly two hours, but in the event dispersed in every direc. tion. The party under M'Ginnes lost but twelve of their men. Their brave but unfortunate commander arrived the same day at Johnson's camp, but died in a few days, of the wounds which he had received in the battle.

POL. I

IV 2 
In these engagements, the greatest loss of the provincial troops, fell upon the detachment sent out in the morning. Colonel Williams, major Ashley, captains Ingersoll, Porter, Farrel, Stoddard, Stevens, M'Ginnes, with about one hundred and thirty men were slain. About sixty were wounded, among whom was general Johnson. The Indians estimated their loss at forty men; among these was Hendrick, the old Mohawk sachem. In the French army, the loss was said to amount to six or seven hundred. Among the slain were several officers of distinction, with M. St. Pierre, a major general, and commander of the Jndians; but few pris. oners, not more than thirty were taken.

THE conduct of M. Dieskau in this expedition $_{r}$ cannot be viewed as the result of much discretion; or of good intelligence. The garri. son at Fort Edward, at that time, did not amount to more than fivo huncired men, under the command of colonel Blanchard of Newhamp. shire. The works were unfinished, and capa. ble of but little defence. Against this place Dieskau might probably have succeeded. But to attempt to destroy the provincial army at the lake, which was four thousand strong, with a very inferior force, bore the appearance of rashness rather than bravery. By the officers of the most experience in the provincial army, it was said, his most capital mistake was in making a halt when he arrived at the provincial camp : That such was the hurry consternation, and want of intelligence in their camp, that if the enemy had marched immediately to their breast work, as their defeated and afirighted troops re- 
turned, it was not improbable they might have increased the confusion and consternation, till it issued in a dispersion of their troops, By making a halt, and firing in platoons at a distance in which it could have no effect, the provincials acquired experience, found the enemy's fire to be harmless, that their own was much better clirected, and did the most execution. It was also a great misfortune to the French army, that their general continued the attack, long after it was found to be unsuccessful, and unavailing.

A VICTORY at that time was so unusual in America, that not to have lost a battle passed for an act of much merit and heroism; and Johnson vas much commended that he had not been defeated. His conduct however did not pass without some severe remarks and censure. It was said there was no generalship in the management of any part of the business; that an army of four thousand men, with artillery, and a breast work, could not be in any danger from such an enemy; and ought to have destroyed their whole army. But most of all was he censured for not sending outa detachment in pursuit of a defeated, retreating army; this was warmly urged by genera! Lyman, but was opposed by general Johnson, and most of his field officers. Instead of making any attempt to pur. sue the enemy or to move forward to Ticonderoga, the day after the battle Johnson wrote to the governors of the colonies for a reinforcement; informed them that he expected another attack, and that the enemy would come on with their artillery; that he should order the troops at fort Edward, to reinforce him ; and that as 
soon as the fresh troops should come on, he. should immediately set about building a fort How far the intelligence which Johnson had, might justify this extreme caution, we cannot now determine. The event was, that instead of risking any thing against the enemy, he spent the remainder of the campaign in building a fort at the south end of lake George, which has since been called fort William Henry, *

Trus terminated the American campaigns in the year 1755. The plans had been chiefly formed by governor Shirley ; an able and judicious statesman, well acquainted with American affairs, and deeply engraged in the interest of the colonies. They appeared to have becn so well concerted, that they were approved and confirmed by general Braddock, and the council which he assembled at "Alexandria. One only had succeeded: That at Nova Scotia, though ostensibly under the command of Monckton, had been principally conducted by colonel Winslow; and had fully effected the purpose of subduing the French in that province, and preserving it to the British dominions. The expedition under Braddock was conducted with extreme imprudence and rashness, and had terminated in destruction and disgrace. The Nia. gara expedition under Shirley, was too extensive in its plan and object, to be compleated in one campaign. At the northward, the baron Dieskau had given Johnson an opportunity to. obtain a victory, without leaving his camp, or: exposing himself to any danger. Braddoch

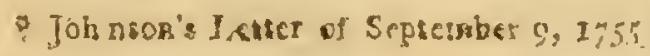


was slain, Shirley had lost much of his popularity, Johnson was celebrated by some and censured by others, while Winslow was every where commended and applauded.

Tin campaigns being closed, general Shirley convened a grand council of war at New York, to settie the plan of operations for the next year. This council was opened on the twelfth of December, and continued its session that day and the next. 'The invitation to the governors of the colonies was universal; but the council was attended only by the following members; the governors of Massachusetts, Connecticut, New York, Pennsylvania and Maryland; colonels Dunbar and Schuyler, majors Craven and Rutherford, and the deputy quarter master general. Shirley laid before the council, the king's instructions to general Brad. dock ; and proposed as a plan of operations for the next ycar, that expeditions should be car. ried on against fort Du Quesne, Niagara, and Crown Point; and that a body of troops should be sent by way of the rivers Kennebec and Chaudiere, to kcep up an alarm in the nighborhood of Quebec, and the eastern parts of Canada. Shirley's plan was adopted rith great unanimity of sentiment, and the council dissolved in perfect harmony, after a session of two days. The governors returned to their respective provinces, but Shirley tarried at New Yurk, in hopes to prosecute an expedition agoinst Ticonderoga in the winter, which the season however did not permit.

1756. THE plan of operations concerted at New York, in a few days after, was traismitud 
to the British minister, to be laid before the king, for his approbation. -This business being adjusted, on January the twenty first, Shirley set out for Boston, to micet the assembly of Massa. chusetts, and propose to them the raising of their quota of the troops. The assembly was disgusted with the proceedings of the last cantpaign, especially at general Johnson's neglecting to pursue his advantages after the defeat of Dieskau. It was with difficulty they were per:suaded to concur in another expensive expedition ; nor would they engage in offensive operations at the lake, till it was understood that Winslow was to have the command of the troops designed against Crown Point. The governor"s influence however prevailed, and the assembly concurred in all the military measures, which he proposed.

Is April, news arrived from Great Britain, that the events of the last year were viewed in a very clifierent light there, from what they were in America: That the affair at lake George was considered by the British ministry, as a very important victory ; and Johnson's conduct as highly deserving and meritorious: That he was honoured with the dignity of a Baronet; and that fire thousand pounds sterling had becrir. voted to him by the house of commons as a fur: ther reward for his services: That his engineer. was promoted to the rank of a major in the British scrvicc, and his secretary to the command of a company. It was also said that general Shirley's conduct had been entirely clisapproved by his majesty, that he was removed from the porsmand of the troops; and that the carl of 
London was àppointed general and commander in chief of all the forces in North America: And that the favorite object with the Britisl ministry, was the reduction of Crown Point.

At this time, general Shirley had not receiv. ed the king's orders, with respect to the late plan of operations; but was much engaged in carrying it into effect. On these venth of May; he arrived at Albany, and immediately began his preparations for the campaign. On the twenty fifth, he held a council of war, consisting: of lieutenant colonel Gage and Burton, majors Chapmän and Sparks, Sir John St. Clair, and Montresor; the chief engineer. With regard to the Niagara expedition, he informed the council that upon lake Ontario, there was a naval force of two vessels of ten carriage guns each; two row-gallies of ten swivels each; and that he had issued orders for building thrce other vessels, one of eighteen, one of sixteen, and one of twelve carriage guns. Besides which, there would be on that lake, two hundred and fifty whale boats, each capable of carrying sixteen men. With respect to the expedition against Crown Point, the council were told, that the several colonies had voted to raise eight thou. sand and eight hundred men, including those which were in garrison at the forts Edward and William Henry. The council were of opinion that thirteen hundred men ought to be posted at Oswego, and four hundred at the different posts between that place and Schenectady. That two British regiments, with the colony troops, would be sufficient for the reduction of Crown Point ; and that a fort ought immediately to be 
built at South Bay, the place where Dieskau had landed his troops.

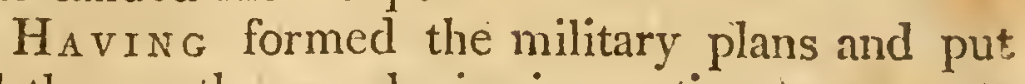
all the northern colonies in motion to execute them; Shirley was deeply engaged in the business till the arrival of major general Webb, on June the seventh. It was now certain that general Shirley was supersecled in the command. On June the fifteenth; major general Abercrombie landed at New York, and in ten days repaired to Albany, and took uponi himiself the command of the army. Shirley immediately delivered to him the returns of the army and stores; and gave him the necessary information respecting the plans of the campaign; the state of the American colonies and troops, and the situation of their forts and public affiirs ; and continued no longer at Albany than was necessary to compleat this business. General Abercrombie was of a family much distinguished in Scotland; had risen in the army by a regulat course of service, and acted with reputation under the dukc of Cumberland, in subduing the rebellion in the year forty six. He was now advanced in age, and but little acquainted with the affairs of the American colonies. When he took the command of the troops; they consisted of two regiments which had served under Braddock, two battalions raised in America, two British regiments which. he brought over with him, four independent companies which had been for many years maintained in New York, four companies raised by the province of North Carolina, and the large body of provincial troops which had been raised for the expedition against Crown Point. 
AN important part of the service respecting the western campaign, was the direction of the batteaux; by these, the troops, provisions and military stores were to be transported from Schenectady to Oswego. Shirley, fully apprehensive of the importance of this service from the sufferings of the former year, had enlisted forty companies of fifty men each for this business. Colonel Broadstreet, an actire, judicious officer, well acquainted with the nature of the business, had been appointed to the com. mand. In returning from Oswego with three hundred of his men, as he was stemming the stream of the Onondago river, with his batteaux formed into three divisions, on July the third, the Indian war-whoop resounded from the north shore, and he was attacked in an instant by a general discharge of musquetry. With perfect coolness, Broadstreet landed his men on the other bank, took possession of an island from which he could annoy the enemy, followed them to every place where they had passed the river, and fell upon them sword in hand wherever he could find them in any numbers. Several actions took place along the banks and islands of the river; the engagement continued for three hours, and in the event, the enemy were every where repulsed and dispersed. In this contest the force of the enemy amounted to seven hundred men. Thirty of the batteaux men were killed, and as many wounded. The French and Indians lost one hundred and twenty, and about seventy of them were made prisoners.

$\mathrm{O}_{N}$ the eleventh of July, Broadstreet arrived at Schenectady. The nest day he repaired to VOL. I. X 2 
Albany, to lay before general Abercrombie, the intelligence he harl obtained, of the danger which threatened Oswego. The prisoners he had taken in his late actions, informed him that twelve hundred of the enemy were encamped on lake Ontario, at but a little distance from the English forts; that they were provided with: artillery, and all other implements necessary for a. siege; and that they meant to commence their operations, as soon as some expected reinforcements should arrive. Upon this intelligence orders were issued to general Webb, to hold himself in readiness to march for the deience of Oswego, with the forty fourth British regiment. While the British generals were thus speculating about Oswego, Lord Loudon who had been appointed to the chief command in North America, arrived at Nerv York, July the twenty third, and reached his head quarters at Albany.; the twenty ninth ; and immediately took upon himself the command of the troops. Amidst the parade and ceremonies attending the arrival and reception of the Rritish generals, the affairs of the war were not attended to ; and it was not till the twelfth of August that Webb set out with his regiment from Albany for the preservation of Oswego. He had proceeded on his journey but a few clays, when he received news. that Oswego was actually besieged by a large army of French and Indians. Alarmed for his. own safety, he madc a forced march to the Oneida carrying place; when he immediately began to throw up works for his own defence. and to fall the trees in Wood Creck, to prevent the enemy from approaching his own samp. 
WHIL the British generals in America were: thus spending their time to no purpose, M: Montcalm, the commander of the troops in $\mathrm{Ca}$ nada, was deeply 'engaged in a scheme of the highest importance to the French interest; that of securing to themselves the extensive dominion of the Great Lakes, which they well knew would command the interest and influence of all the Indian nations. As the first step to eflect these measures, he sec forward it cxpedition against Oswego, while the British generals were looking for him at Tyconderoga. He assembled a body of troops, consisting of thirteen hundred regulars, seventeen hundred Canadians, and a considerable number of Indians. With this force he proceeled from fort Frontenac, by the way of lake Ontario. The first step taken by Montcalm, was to block up Oswego by water, by two large armed vessels; the next, was to post a strong body of Canadians and Indians on the road betiveen Albany and the forts, to cut off all communications of succour and intelligence. Having brought up his artillery and stores, he had every thing in readiness to open his trenches before fort Ontario, by the twelfth of August. The forts were in no condition to make a defence against artil. lery or regular approaches. On the thirteenth, colonel Mercer was killed by a cannon ball ; and the next day the garrison proposed a capitulation. The terms were, that they should surrender prisoners of war, be exempted from plunder, tredted with humanity, and be conducted to Montreal. Unfortunately for several of the prisoners, and for the honor of Montcalm, the terms of the capitulation were not fulfilled by 
him. Several of the British officers, and sole diers were insulted, robbed, and massacred by the Indians. Most of the sick were barbarous1y scalped in the hospital; and to compleat the scene of falshood and barbarity, the French gencral clelivered up to the Indians above twenty of the garrison, in the room of the same number that they lad lost during the siege. 'In' all probability these unhappy victims were put to death, according to the execrable Indian cus. tom of torturing and burning. Having succeeded in the enterprise with scarcely any loss, Montcalm clemolished the two forts at Oswego, and, returned with his army to fort Frontenac. In this expedition he had taken fourteen hundred prisoners, one hundred and twenty pieces of artillery, fourteen mortars, with a large quantity of ammunition, warlike stores, and provisions ; two sloops, and two hundred batteaux.

While these scenes, disgraceful to the English, were taking place at Oswego, and the French every where conducting their affairs with wisdom and energy, the British generals at Albany appeared to be either wholly unacquainted with the business, or disinclined to the dangers and hardships of an American, French and Inditn war. The force in the vicinity of Aibany, under the command of the earl of Loudon, amounted to two thousand and six liundred regular troops, and eight thousand proviirriais, weil clothed, fed and armed ; and provicied with the necessary artillery and implements of war. General Winslow for several rionths had been at lake George, with an army of seven thousand provincial troops, well equip. 
ped, and ready to proceed from fort William Henry. From the best accounts, the force of the firench at Ticonderoga and Crown Point, dir? not exceed three thousand men; and with this force, they did not appear to be in any degree aprirehensive of any danger from the Eng. lish. Nor had thcy any thing to fear from the British generals, forces, or exertions ; for nothing was attempted or effected. Loudon neither made any attempts, nor gave any orders to his troops to move forward, or molest the enemy on lake Champlain. Loudon had his head quarters at Albany, Winslow lay with the provincial army at lake George, the season passed away, and all that was attempted or performed was to strengthen the forts Edward and William Henry, which Lyman and Johnson had built the year before.

A party, in some of the colonies, had been extremely active in censuring the measures of general Shirley, and in effecting his removal from the command. 'They had already discovered that he was much better acquainted with American affairs, more judicious in his plans, and more active in executing them, than the British generals who had succeeded him. If Shirley had attempted too much, they had attempted nothing; and if Braddock had lost his life and army by his rashness and confidence, Loudon and his officers had neither ventured, effectet, or lost any thing : And it was already apparent, either that they were altogether unacquainted with the nature of that kind of war, which must be pursued on the American frontiers; or eise they were disinclined to venture 
amidst the fatigues, dangers, and surprises, to which it was unavoidably exposed. But whatever was the cause, it was every where known that the whole body of British and provincial troops, through the whole of this campaign, had been employed to no manner of purpose. Disappointment and disgrace had attended every. British measure; it was the French, with $M$. Montcalm, their general, that had:acted wits vigar and success. 


\section{HISTORY OF VERMONF。}

\section{CHAPTER XI:}

W. R. Progress and cvents of the war in the years 1757 and 1758. Loudon's preparations for the campaign. Montcalm's measures with the Indians. Designs upon the English. Putnam's account of Webb's proceedings: Conguest of Fort William Henry. Savage massacre of the prisoners. Reflections on Mont: calm's conduct. Result of the campaign in 1757. Change of the British councils and ministry. Conquest of Louisbourg. Aber: crombie's attempt and defeat at Ticonderoga. Capture of Irort Frontenac by Broadstreet... Of Fort Du Quesne by Forbes. Amherst as: sumes the corimand.

1757 THE Earl of Loudon had been an officer of much reputation in Scotland. In the rebellion in that country, in the year one thousand seven hundred and forty five, he commanded a regiment of Highlanders at Inverness ; was wery useful in directing the councils and conduct of the clans, who had taken arms in behalf of the king; virilant and successful in restraining and intimidating the disaffected chiefs, who had not openly joined in the rebellion ; loyal, active, and persevering, he had rendered very useful services to his majesty, in the high lands of North Britain. From such serrices and expcrience, it was supposed that he was. well qualified to have the dircetion of the * var in North America.

H I ING assumed the command of all the 
forces in North America, he was employed duris ing the winter in effecting his purposes with the American governments, to raise a large body of troops for the ensuing campaign. If is Lord: ship had not the full confidence of the American assemblies; but such was their conviction of the necessity of more vigorous measures in carrying on the war, that they every where raised the number of troops which were requir. ed of them, and made all the preparations which were expected: But as the British general had taken the direction of all the proposed exipditions under his own management, neither the American governors or assemblies, were employed in forming plans, or concerting measures for their own defence, or to annoy the cnemy. The time was now come, when it was though by the British ministry that it was not best for their colonies to learn their own strength, or to depend upon their own councils; bit to look to British officers and troops for the oine, and to the British ministry for the other.

From the first commencement of hostilities, the reduction of Crown Point had been the favorite object with the colonies, and with the crown. It was determined in the British couns cils of this year, to vary and extend their operations; not to carry their expeditions against Crown Point, but to make a vigorous attempt against Louisbourg. In pursuance of this plan, Admiral Holbourn arrived at Halifix, on July the ninth, with fifteen ships of the line, and a large number of transports. Lord Loudon had collected a body of six thousand troops, and embarked from New York, to take the command 
of the army designed for Louisbovig. When the arrived with his troops at Talifir, he found himself at the head of twelve thousand men; well officered, disciplined, and provided with every thing necessary for the expedition. While the army lay at Halifax, preparing to embark, inteligence was received that $\mathbf{M}$. de la Mothe had sailed from Brest, in the month of May, and was arrived safe at Lonisbourg, with a large fieet of ships of war, and transports. The intelligence was soon confrmed, with more particular information; that there were seventeen ships of the line and three frigates moored in the harbor ; a land army of six thousand regular troops, three thousand natives, and thirteen hundred Indians ; that the place was well supplied with ammunition, provisions, and every kind of military stores: and that the enemy werc expecting and desirous of a visit from the English fleet and army. This intelligence put an end to Loudon's deliberations. No attempt was made to proceed in the expedition, it was foreseen that the consequence of a defeat would have been greatly injurious to the British affairs in America. And neither their admirals or generals had as yet acquired that determined resolution and perseverance, which were necessary to give success to the American contest.

But whatever was the case with the British commanders, the French generals perfectly well understood their business. Montcalm, who had the command of the troops in Canada, was an able and experienced officer. He had served with much reputation in the French armies in Italy and Bobemia, and bad met with much

YOL. I. 2 
success in America. The conquest of Oswego had rased his fame among the Indians, and siven lin the commant of almost all their tribes and commerce. Ele pursucd the adrantages he had obined with much discretion and address. The Engish liad destroyed their forts at the great carwing pace, and in other parts of the Indian countr, to prevert their folling into the hands of the liencin; and the whole countiy of the sis nations was airdoned to the cnemy. The Frenc? commanders arailed themselves of all the errors and defunts of the English. They carried fire and smond into the Hudian connery; and $b_{j}$ rewards, promises, and threatenings, were incessanty enfeavoning to dran over the six nations to their interest; and they had the inost flattering prosiccts of success. These nations alone, of all the Indian tribes, had been sincere and faithful in their attachment to the English. The forts, and communications with their tribes were cut off, their country was abandoned to the incursions and ravages of their enemies, and their English allies had met with little else than disappointment and defeat in all their expeditions against the French. In sucl circumstances it required all the ability and address of sir William Johnson, to prevent their deserting the English cause and interest.

BY the departure of lord Loudon from New York, the command of the British forces had devolvect on major general Viebb. Intealin saw that a favorable opportunity was prescnted to attack the English on lake George. He had made an attempt on the twentieth of Mircl, to enry fort Willim Henmy by surprise; but his 
troops had becil defeated by the vigitance and bravery of the garrison. Several of the cincmy were slain, but they did not returi til the had buried two sloops, 2i one on the stocks; almost all the batteanx, three store houses, all the huts of the rangers, and every thing that was not under the command of the fort. At the opening of the spring, a detachment of near four hundred men wentown the late wher the command of colonel John Parker, in batteenx and whale boats, to attempt the enemy's advanced guard at Ticonderoga. Parker was deceired in his intelligence, decoyed into the midst of a large but concealed party of the enemy, and attached with such impetuosity and success, that but two offeers and seventy privates escaped. Encouraged by this success, and the departure of lord Loudon to Hahifar, and wishing to retrieve the misforture of the defeat at fort Wil. liam Henry, Inontcalm drew his forces together and made preparation to lay sicge to that place. For this purpose he assembied at Crown Point and Ticonderoga, a large boly of regular troops, Canadians, and Indians, amounting to nèar ten thousand men.

ONE of the great dificulies attending the American campaigns, was the aricle of intelligence; to procure information of the strength and movements of the enemy. The most that was obtained, was generaliy by means of scoutiig and ranging paries. "Some of the offeers of the New Hampshire troops, were much dis. tinguished for their abilities and exploits in services of this kind. "To three of them, Robert Rogers, John Stark, and Whin Stark, ranging. 
companies were assigned. At the desire of lor Loudon, they were continued in the service dur.. ing the winter as well as summer. 'They were so eminently useful in ranging the woods, procuring intelligence, and skirmishing with the advanced partics of the enemy, that they were put in the pay of the crown \& after the war were. allowed half pay on the British establishment. $T$

Among the ofticers of the ranging companies, major Putnam, whose name became so much celebrated in the American war, was at that ime much distinguished for his activity and bravery. General Webb had formed a high idea of his military character and enterpiise, and had assigned to him the command of a party of two hundred men, who had been selected to escort Webb from for 1 idward to Willam Henry. Webb wished to examine the state of the fortifcations at lake George, and to procure inteiligence of the strength of the enemy at Piconderoga and Crown Point. Several attempts had been malde in the night by major Rogers, who was then at the head of the ranging compries, but they had not succeeded. Putnam proposed to proceed in the day time, take with him but lve naen, land at the Norhwest bay, send back his boats, and tarry himself till he could disccrer the state of the enemy's troops and fortifications at Ticonderoga. Webb tho ght this would be too dangerous an experiment, but permitted him to proceed with eighten men in three whale boats. Putnam set out with his voluntecrs, but before he arrived at the Northwest bay, he discovered a body of t Belknap's Hist. New Isamponire, row 2. p. $29 \%$ 
men on one of the islands in the lake. Leaving two of his boats to fish at a distance, that they might not occasion any alarm, he returned hin:self with the information. The general saw him rowing back with great velocity in a single boat, and concluded that the other two had been captured; he sent orders to Putnam to leave his men in the boat, and come ashore alone. Putnam informed him of the discovery he had made, and urged the necessity of returning immediately to make further discoveries, and bring off the boats. Webb reluctantly consented, and Putnam hastened to seeure his boats; having joined his men, he pressed further on till he discovered a large army in motion, and was scen by the enony. Several of their canoes pursued him, and though nearly surrounded at times, by the most vigorous exertions he cscaped. On his return, he gave to general Webb, a minute account of all that he had seen and added that the army of the enemy must undoubtedly be designed against fort William. Henry. General Webb enjoined the most absolute silence upon the subject, and directed him to put his men under an oath of secrecy, and prepare immediately to return to the head quarters of the army at fort Edward. Wishing to be engaged in surprising the enemy on the lake, Putnam made this remark, "He ho. ped his excellency did not intend to negleet so fair an opportunity of giving battle, should the enemy presume to land." "What do you think we should do here," replied the general. The next day, Webb returned to fort Edward, escorted by Putnam; and the day after, colonel 
Monro was ordered with his regiment to reill. force the garrison at lake George. Aware of the siege that was about to commence, Putnam advised colonel Monro not to carry his costly baggage \& camp equipage; but Monro, uot apa - prised of the inteligence which had been given to Webb, disregarded the advice and marched on without any anprehension of immediate dan. ger. $\uparrow$

The day after Momo had arrived and taken the command, the lake appeared to be covered with boats; and a large army of French and Indians were swifit approaching towards the fort. Montcalm effected a landing with but little opposition, and immediately began the siege. Asmall party of the garrison had a shirmish whith some of the advanced partics of the enemy, and some that had been taken prisoners, had been murdered and scalped by the Indians with circumstances of the most inhuman barbarity. Fi. himself of this event, and cndeavoured to pursuade the garrison to an immediate surender. On the day in which he mpested the plinee, he sent a leter to colone Monro, stating that he thought himself boand in humanty to vere him to sumender before any of the fucians were stin, \& their savage temper sinou be further in. flamed by a recistance wheh could not be arailing. "A detachment of rou parison, say" "he, has lately cxperionced ther cruelty; "have it yet in my power to restmin therr, and "oblige them to obsere a ceppitulition, as nons. +Hunphrey' life of Putnam, p. 37. 
" of them hitherto are killed. Your persisting $\checkmark$ in the ciefence of your fort, can only retard its ' fate a few days, and must of necessity cxpose 'an unfortunate garrison, who can possi'bly receive no relief, considering the precau"tions I have taken to prevent it. I demand a "decisive answer, for which purpose I have " sent the Sieur Funtbrune, one of my aidles. "du camp. You may credit what he will in. "form you of, from Monicalm."

COLONEL Monro was an officer of distin' guished honor and fortitude. He returned a very proper and spirited answer, announcing to the French general, that as the fort had been entrusted to him, his honor and his duty would lead him to defend it to the lase extremity. A. ware of his clanger, he sent one express after another to Webb, informing lim of his own situ. ation, and the sirength of the enemy, with the most pressing solicitations for immediate succour. The garrison consisted of about two thousand five hundred men; the whole of which, animated by the hope and expectation of receiving relief from fort Edward, made a gallant defence.

Generat Webb had an army at fort Ed. ward of four thousand men, which had been considerably augmented by the troops under the command of Sir William Johnson, and by the militia. It is generally supposed that he had private intelligence of Montcalm's designs and motions; and it was in his power to have called in a large number of provincial troops from New York and New England; and these were in fact the best soldiers in a war with the 
Canadians and Indians. But he neither seem: ed to have any apprehension of danger, or to make any excrtions to prevent or avoid it; but remained rather indifferent or passive amidst all the alarming scenes that were taking place. Such however were the representations from Monro, and the solicitations in his own camp, that on the eighth or ninth day of the siege, general Johnson was suffered to march with all the provincial regiments, the militia, and Putnam's rangers. They had not proceeded three miles before the order was countermanded, and the troops directed to return. Webb then wrote to Monro that he could not afford him any relief, and advised him to surrender on the best terms that he could obtain.

MontCalm was provided with a good train of artillery, and had been accelerating his approaches to the fort with all the expedition in his power. When Johnson began his march, some of the Indians who were employed as runners, saw the movement and gave the inform tion to Montcalm, that a large force was approaching towards the lake. Being questioned respecting the numbers, they answered in their figurative manner, "If you can count the leaves of the trees, you can count them, \&xc." In consequence of this intelligence, the operations of the siege were suspended; and Montcalm was preparing to give batile, or retreat, as circrimstances might dictate. Another Indian runne: put an end to the apprehensions of the Fench, by the welcome tidings that the English amy had returned to fort Edward.

- Puenam's life, p. 38. 


\section{HISTORY OF VERMONT.}

return of this detachment, Montcalm found that he had nothing to fear from the British army at fort Edward, and prosecuted the siege with fresh vigor, and the most confirmed hopes. Monroe and his garrison defended themselves with much spirit and resolution till their works were much injured, their ammunition nearly expended, and the enemy had made near approaches to the fort. Still expecting to be relieved by general Webb, Monroe had refused all terms of capitulation from the third to the ninth of $\mathrm{Au}$ gust. Montcalm had intercepted the letter which Webb had wrote to Monroe advising him to surrender.* This letter was sent into the fort to Monroe, with further proposals for a ca. pitulation. Every circumstance now served to convinceMonroe that it would be impossible for him to preserve the place, or to hold out much

\section{* Fort-Edward, August 4, 12 at Noon.}

SIR, "I am directed by General Webb to acknowledge the res ccipt of three of your lctters; bearing date nine o'clock yefterday morning, and one about six in the evening, by two rangers, which are the only men that have got in here, except two yesterday morning with your first,acquainting him that the encmy were in sight. He kas ordered me to acquaint you, he does not think it prudent, (as you know his strengtb. at this place) to attempt a junction, or to assist you, till reinforced by the militia of the colonies, for the immediate march of whieh repeated ex presses have been sent. One of our scouts brought in a Canadian prisoner last night, from the investing party, which is very large, and bave possesscd all the grounds five miles on this side of Fort William Henry. The number of the enemy is very considerable, the prisoners say eleven thoustnd, and bave a large train of artillery, with nortars, and were to open their hatteries this day. The gencrat thouglit proper to send you this intelligence, that in care he slionld be so unfortunate, from the delays of the militia, not to have it in his puwer to give you timclyassistance, you might be able to make the best terms left in your powcr. The bearer is a set: reant of the Connecticut forces, and if he is happy enougb to get in wit bring advices from you. Wekecp continual scouts going, to endearor to zet in, or bring intellirenee from you. I am, sir, with the heartiest and: most anxious wizliss for yuur welfare, your most obedlent lumble ser. vant.

To Col. Monroe, er oficer enmmanding

$$
\text { G. BARTMAM, Ald-ds-CAmp. }
$$
at Fort IVilliand I Ieny. 
longer against the French army; and that he must surrender on the best terms that he could obtain.

ArTICLEs of capitulation were agreed upon and signed by Montcalm and Monroe. It was stipulated that the garrison of fort William Hen$r y$, and the troops in the retrenched camp should march out with their arms, the baggage of the officers and soldiers, and all the usual necessaries of war; and be escorted to fort Edward; by a detachment of French troops, and interpreters attached to the savages. That the gate of the fort should be delivered to the troops of the most christian king, immediately after signing: the capitulation ; and the retrenched camp, on the departure of the British troops: That all the warlike stores, and every thing except the effects of the officers and soldiers should be deIivered to the French troops. The garrison was not to serve against. France or her allies during the term of eighteen months. Such of the French as had been taken prisoners since the commencement of the war, were to be delivered at Carillon, (Ficonderoga) in the space of three months; in return for which, an equal number of the garrison of fort William Henry should be capacitated to serve in the English armics. The sick and wounded were to remain under the protection of. Montcalm, and were to be treated with humanity and tenderness, and returned as soon as they were recovered. An officer was to remain as an hostage till the safe return of the cscort that was to be sent to guard the British troops to fort Edward: And as a testimony of his csteem and respect for colonet. 
Monrce and his garrison, on account of thei: gallant defence, Montcalm was to return one cannon, a six pounder.

$\mathrm{T}_{\mathrm{H}}$ articles of capitulation were signed August the ninth, and no further difficulties were expected. But no sooner had the British trooss marched out of their camp than a scene of perfidy and barbarity took place, that had scarcely ever before been acted among the most brutal of barbarians and robbers. In avowed contempt and violation of the articles of capitulation, the Indians attached to the French army fell upon the defenceless garrison, plundered, wounded, and murdered whatever stood in their way. 'The following is the account of Captain Jonathan Carver, of the Connecticut troops, and one of the garrison at that time. "The morning after " the capitulation was signed, as soon as day. "broke, the whole garrison, now consisting of s about two thousand men, besides women and " children, were drawn up within the lines, and " on the point of marching off, when great num- bers of the Indians gathered about, and began to plunder. We were at first in liopes that this was their only view, and suffered them t'

'proceed without opposition. Indeec? it $w$

" not in our porver to make any, had we br

'so inclined ; for thangh we were permitte

c carry off our arms, yet we were not allor

' single round of ammunition. In these

"however we were disappointed; for p;

" some of them began to attack the s

' wounded, when sirch as were not ablk .

' into the ranks, notwithstanding they

: ored to avert the fury of their enemio slrieks or groans, were soon dispatm 
- Her we were fully in expectation that the - disturbance would have concluded; and our - little army began to move ; but in a short - time we saw the front division driven back; ' and discovered that we were entirely encircled

- by the savages. We expected every moment - that the guard, which the French by the arti-

- cles of capitulation, hach agreed to allow us,

- would have'arrived, and put an! end to our ap.

"prehensions; but none apperred. The In-

- dians now began to strip every one without

" exception, of their arms and clothes, and those

- who made the least resistance felt the weight:

" of their tomahawks.

- I happened to be in the rear division, but - it was not long before I shared the fate of my

- companions. Three or four of the savages.

- laid hold of me, and whilst some held their

- weapons over my head, the others soon disro.

- bed me of my coat, waistcoat, hat and buckles,

4 omitting not to take from me what money I

: had in my pocket. As this was, iransacted close by the passage that led from the lines on 0 the plain, near which a French centinel was. isted, I ran to him and claimed his protec.

z; but he only called me an English dog, thrust me with violence back again into nidst of the Indians.

Jw endeavored to join a body of our that were crowded together at some '; but innumerable were the blows. e made at me with weapons as I pas. 'uckily however the savages were so. ther, that they could not strike at endangering each other. Notwith- 
' standing which, onc of them found neans to

' make a thrust at me with a spear, which grazed

' my side, and from another I received a wound, ' with the same kind of weapon, in my alicic. - At length I gained the spot where my comn'trymen stood, and forced myself into the mistst ' of them. But before I got thus far out or the ' hands of the Indians, the collar and wristbarsis ' of my shirt were all that remained of it, and "my flesh was scratched and torn in many p": 'ces by their savage gripes.

' $\mathrm{Br}$ this time the war whoop was given, an the Indians began to murder those that wee ' nearest to them without distinction. It is

" in the power of words to give any toler. - idea of the horrid scene that now ensu:

' men, women, and children were dispatcher

' the most wanton and cruel manner, and

"mediately scalped. Many of these savi

"drank the blood of their vicinins, as it fich warm from the fateil wound.

- WE now perceived, though too late to are ' us, that we were to expect no relicf from

"French; and that, contrary to the agreens

'they had so lately signed, to allow us a sw

' cient force to protect us from these inst.

- they tacitly permitted them; for I could pl:

"ly perceive the French officers walking abe

' at some distance, discoursing' with apparci...

" unconeern. ****** * *

'As the circle in which I stood enclosed,

"this time was much thinned, and death seemer

' to be approaching with hasty strides, it wis " proposed by some of the most resolute to malks: " one vigorous effort, and endeavor to force ous 
' way through the savages, the only probable ? method of preserving our lives that now remained. This, however desperate, was resolved on, and about twenty of us sprung at sonce into the midst of them.

'IN a moment we were all separated, and - what was the fate of my companions I could. ' not learn till some months after, when I found - that only six or seven of them effected their "desigo. Intent only on my own hazardous " situation, I endeavored to make my way thro" "my savage enemies in the best manner possi- ble. And I have often been astonished since.

" when 1 have recollected with what composure

- I took, as I did, every necessary step for n?y

- preservation. Some I overturned, being at that

- time young and athletic, and others I passed

- by, dexterously avoiding their weapans; till ' at last two very stout chiefs, of the most sar-

'age tribes, as 1 could distinguish by their

' dress, whose strength I could not resist, laid

' hold of me by each arm, and began to force. "me through the crowd.

'I now resigned myself to my fate, not ' doubting but that they intended to dispatch me, 'and then satiate their vengeance with my - blood, as $l$ found they were hurrying me to- wards a retired swamp that lay at some dis-

" tance. But before rie had got many yards, an - Enghish genuleman of some distinction, as 1 'could discover by his breeches, the only cov' ering' he had on, which were of fine scarlet selvet, rushed close by us. One of the In" dians instantly relinquished his hold, and springing on this new object, endeavored the 


\section{HISTORY OF VERMONT.}

seize him as his prey; but the gentleman be "ing strong, threw him on the ground, and would probably have got away, had not he ' who held my other arm, quitted me to assist ' his brother. I seized the opportunity, and ' hastened away to join another party of English 'troops that were yet unbroken, and stood in a - body at some distance. But before I had ta' ken many steps, I hastily cast my eye towards ' the gentleman, and saw the Indian's tomahawk ' gash into his back and heard him utter his last - groan ; this added both to my speed and dessperation.

'I had left this shocking scene but a few 'yards, when a fine boy about twelve years of "age, that had hitherto escaped, came up to me ' and begred that I would let him lay hold of ' me, so that he might stand some chance of " getting out of the hands of the savages. I told ' him that I would give him every assistance in - my porrer, and to this puirpose bid him lay 'hold; but in a few moments he was torn from ' my side, and by his shrieks I judge was soon ' demolished. I could not help forgetting $\mathrm{my}$. " own cares for a minute, to lament the fate of 'so young a s...ferer; but it was utterly im. "possible for me to take any methods to pre. " vent it.

- I now got once more into the midst of "friends, but we were unable to afford each oth" er any succour. As this was the division that 'had advanced the farthest from the fort, I tho' ' there might be a possibility (though but a bare 'one) of my forcing my way through the outer "ranks of the Indians, and getting to a neigh- 


\section{\$96 NATURAL AND CIVIL}

- Eoting wood, which I perceived at some dis- tance. I was still encouraged to hope by the "almost mirriculous preservation I had already

- exirerienced. Nor were my hopes in vain, or

'the efforts I made ineffectual. Suffice it to

'sa', that I reached the wood'; 'brit by the time

- I had penetrated a little way into it, my breath

"was so exhausted that I threw myself into a

'berke, and lay for some minates apparently at " the last gasp. At length I recovered the pow- er cir respiration : but my apprehensiois re-

' tumed with all their former force, when I saw

- sercral savages jass by, probably in pursuit "Of hie, at no very great dlistance. In this sit-

" uaion I knew not whether it was better to " proced, or endervor to conceal myself where 'I lid, till night came on; fearing, however, ' that they would return the same way, I thought ' it most prudent to get further from the dread- ful sccine of my distresses. Accordingly,

- striling into another part of the wood, I has-

' tencit on as fast as the briars and the loss of

" onc of my shoes twould permit me; and after

' a s?ow progress of some hours; : gained a hill - that rverlooked the plain which I had just left,

- froin whence I could discern that the bloody

- storm still raged with unabated fury.

- Fis $T$ not to tire thy readers; I shall only - adci, that after passing threc days without sub:

- sistcuce, and enduring the severity of the cold

- devrs for three nights, I at length reached fort

- Edrurd ; where with proper care my body

" soon recovered its wonted strength, and my " mind, as far as the recollection of the late mci- anchoily events would permit, its usual com.

posire. 
' Ir was computed that fifteen hundred per. ' sons were killed or made prisoners by these 'savages during this fatal day. Many of the ' latter were carried off by them and never re'turned. A few, through favorable accidents, 'found thicir way back to their native country, 'after having experienced a long and severe ' captivity.

' Th е brave collonel Monroe had hastened a'way, soon after the corfusion began, to the - French camp to endeavor to procure the guard 'agreed on by the stipulation; but his application 'proving ineffectual, he remained there till g'en' eral Webb sent a party of troops to demand. ' and protect him back to fort Edward."

THE day after this awful tragedy had been acted, major Putnam was dispatched with his rangers to watch the motions of the enemy. He came to the shore of lake George, when the rear of the enemy was scarcely beyond the reach of musquet shot. The prospect was awful and horrid in the highest degree: The fort. was demolished, the barracks, outhouses and buildings, were one heap of ruins ; the cannon, stores, boats and vessels, were carried away. The fires were still burning, the smoke and stencir offecnsive and suffocating. Innumerable fragments of human sculls and bones, and carcases half constumed, were still frying and broiling in the decaying fires. Dead bodies mangled with scalping knives and tomahawks, in all the wantonness of Indian fierceness and barbarity, were every where to be seen. More

- Carrec. Trevais, 181-186.

fol. I. A 3 
than one hundred romen inhumanly stabbed and butchered, lay naked on the ground with their bowels torn olit, and still weltering in their gore. In some, their throats were cut ; in others, their brains were oozing out, where the hatchet had cleaved their heads; and in others, the hair and the scalp had been torn off, and nothing was to be seen but the bloody skull. Devastation, barbarity, and horror, every where appeared; and presented a spectacle too diabolical and awful to be endured or described.*

IT is difficult to believe that the French offcers had contemplated any such proceedings. As soon as the capitulation was signed, St. Luke le Corne, who had much infuence among the Indians, sent for colonel Frye, who commanded a part of the Massachusetts troops. Frye had been in Nova Scotia under Winslow, in 1755, and had protected several of the French inhabitants from the fury of the Indians. Le Corne told hin that he had observed, and that he weil remembered the humanity, that he had shown to his countrymen in Nova Scotia; that he should embrace the prescnt opportunity to express his gratitude, and reward his humanity; and that neither he, nor any of the Massachusetts troops, should receive any insult or injury from any of the Indian tribes. Frye believed in Le Corne's declarations; but during the whole outrare and massacre, Le Corne neither appeared himself, nor sent any party to afford protection, or to moderate the Indian vengeance. $\dagger$

* Putnam"s Life, p. 39.

* Col. Joseph Frye's relation to the Anthos. 


\section{PISTORY OF VERMONT.}

How far it was in Montcalm's power to lyave prevented this scene of carnage and barbarity, it may not be easy for us to determine. The marquis himself seems to have been a man of humanity and politeness; and it is scarcely poscible but that a brave and generous soldier must have beheld such scenes of outrage, with disgust and abhorrence. Nor was it possible but that he must have been aware of the dangerous consequences of violating the public faith, or how much it would effect his own honor and reputation, to have his prisoners surrendered into his power under a solemn treaty of protection, murdered in his presence, and by a part of his own army. The most that candor can say upon this subject, will bc, that the European generals were not able to restrain the fierceness and barbarity of their Indian allies; that the savages served with them, not under the prom. ise or expectation of wages, but solely with a view of revenge and plunder ; that they claim. ed these as their right, practice, and custom, from time immemorial; and did not admit that any of the European commanders had any right to restrain, or to interpose in their customs and usages of treating their prisoners. But when all has been said that candor can suggest, or that the customs and habits of the savages can justify or excuse, still it will occur, that the garrison had a promise of protection from Mont. calm; that they had surrendered under the faith of this protection; that all the laws of humanity and war required the capitulation to have been held sacred and inviolate; that it was in his power to have protected the garrison by 


\section{NATURAL AND CIVIL}

viaril of ench troops; but that rather than disgust the Inclians, he broke every part of the capitulation, rilated his own honor, and destroyed the faiih of any future promises, by suffering a seduced and defenceless garrison to be plundered and butchered, in the presence and view of his whole army.

ExPECTING to be attacked himself, general Webb hat sent on expresses to the provinces for reinforcements. They were every whcre raised and sent on with great expedition; but as Montcalm had returned to 'Ticonderoga, the reinforcements were kept in service but a few weeks : And thus ended the third campaign in America.

Wiru an army of more than twenty thousand regular troops, a great number of provincial forces, and a raval power of more than twenty ships of the line, nothing had succeeded. Ail attempts against the enemy had failed; and the French, with a much inferior force, had cvery where gained the advantage. The British ministry did not appear to ise sufhciently acquainted with the state of things in America, to form a juclicions plan for a campaign in the eolonies; ner did the British generals appear to be enough informed of thie nature of a French and Indian war, to carry it on with success. Loudon had retumed to New York, and was engaged about the civil aftairs of the colonies. Massachusetts had been the most active of all the provinces in raising men and money for the war. In November, Loudion took offence at some of the proceedings of their assembly; which he construed as implying that an act of their arcembly 
was necessary to carry into effect an act of the British Parliament for quartering their troops.In an hour of resentment he wrote to governor Pownall, November 15, 1757. "I have order. ? ed the inessenger to wait but forty eight hours in Boston; and if, upon his return, I find things not settled, I will instantly order into. - Boston the three battalions from New York, ' Long Island, and Connecticut, and if more are 'wanted, I have two in the Jersies at hand, be"sides three in Pennsylvania." The return not being agreeable to his lordship's feeling, he gavo orders that the troops should march. The. matter being properly explained, his lordship. wrote again, December 26th, "As I can now ' depend upon the assembly's making the point ' of quarters easy in all time coming, I have "countermanded the march of the troops." While Loudon was engaged in such exploits, Webb was safe at fort Edward; towards which the enemy could not approach with much force, during the winter. The French only were in a state of activity and enjoyment: Instead of proving distressing or mortifying to them, the war had served to enlarge the boundaries of Canada, to fill it with prisoners and scalps, with private plunder, with public stores, arms, provisions, and other trophies of triumph.

1758. THE misfortunes and disgraces which had attended the war for three campaigns had been the occasion of ridicule and triumph to the French, and had spread the spirit of jealcusy and discontent in every part of Great Britain,

* Gordon's Hist. Anateriedn War, Vot. I. p. 96. 


\section{OOZ NATURAL AND CIVIL}

and her American colonies. The pcople in both countries became loud and clamorous in their complaints and censures of the British ministry and generals; and it was become ap: parent that the public confidence was withdrawn from the men who had hitherto dirceted the affairs of the war. 'The British nation was alarm. ed with the prospect, and the British court found it necessary to change her councils. A new ministry was formed, and the celebrated William Pits was appointed one of the secretaries of state. Public confidence seemed to rise from the grave, the national spirit was, roused up, and the people every where expecting much from the spirit and virtues, were eager and active to support the measures of their farorite patriot and statesman. The reduction of the French, and the increasing prosperity of the English colonies, had been the avowed objects in all his speeches and proposals; the universal expectation was, that he would now employ the national force in encrgetic and ac. tive services.

Tre plan which the new minister formed for the ensuing eampaign in America, was to attack the French in various parts of the country at the same time. Trvelve thousand men were destined to attempit the conquest of Louisbourg, on the Island of Cape Breton. Sixteen or seventeen thousand men to cross lake George, and make a vigorotis attempt upen the forts at $T$ iconderoga and Crown Point. Eight thousand were to proceed to fort Du Quesne on the Ohio, and invade the French forts and settlesnents in that part of the country. And all the 


\section{IIISTORY OF VERMONT.}

American colonies were called upon, to raise as many troops, and to make all the exertions in their power.

THE reduction of Louisbourg and the island of Cape Breton being an object of immediate consideration, was undertaken with much spirit and dispatch. Lord Loudon had returned to England, and was no longer employed in the affairs of the colonies. The expedition was put under the command of major general Amherst, assisted by the brigadier generals, Wolfe, Whitmore, and Lawrence. The naval force was put under the cominand of admiral Boscawen, who sailed early in the spring with the Reet and forces for America. 'The whole armament collected at Halifaxin Nova Scotia, and consisted of one hundred and fifty seven sail. On May the twenty cighth the fleet sailed from Halifax, and on the second of June, part of the transports anchored in Gabarous bay, about seven miles to the westward of Louisbourg. On the eighth the troops effected their landing under the command of the able and spirited gene. ral Wolfe, and in a few days compleatly invested the city.

LOUISBOURG had a garrison of two thousand five hundred regular troops, three hundred $\mathrm{mi}^{-}$ litia, and was afterwarls reinforced by three hundred and fifty Canadians, including threescore Indians. The harbor was secured by six ships of the line, and five frigates; the whole under the command of the cheveleur Drucour. With much expence and labor, the governor had been preparing for a siege. Amherst made his approaches with great circumspection; 
securing his camp ivith redoubts and epaulments from the insults of the Canadians and Indians; of whom he vas informed there were very con: siderable bodies on the island watching for an opportunity to surprise some part of his camp: Wolfe conducted with all that fre, impetuosity and cliscretion, with which his mame and character have since been distinguished and immortal: isci. Under the direction of these excellent commanders the siege was carried on with so much caution and vigor that the French ships of war were soon destroyed, and the garrison ubliged to surrencier as prisoners of war on the twenty sirth of July. Lond Rollo soon after effected the reduction of the island St. Jolin, which lies in the gulph of St. Lamrence. This island contained above four thousand inhabitants and abounded in black catte and corn.

WHILE Amherst was crigaged in the expedition against Louisbourg, major general Abercrombie was undertaking the reduction of Ti. conderoga. Upon the departure of the earl of Fioudon to England, the chief command of the troops in America had devolved upon him; and" he was directed to open a passage to Canadaby reducing the French forts on lake Champlain. In the beginning of July he had got every thing in readiness to procced. His forces amounted to nearly seven thousand regular troops, and ten thousand provincials. 'These, with a fine train' of artillery, military stores, and provisions, were embarlied on lake Ceorge, on board of nine: bundred batteaux, and one hundied and thirty five whalc bonts; several picces of cannon were wownted on rats to cover their landing. The. 
trext day the troops landed at the place of des. rination, without any opposition.

Tне English troops having landed were immediately formed into three columns, and moved forward toward the enemy. 'The advanced party of the French army consisted of a battalion, which lay encamped behind a breast work. of logs. This party, upon the approach of the English army, set fire to their breast work and tents, and abandoned them with precipitation. The English forces continued to advance in regular order, but their route lay through a thick wood, which would not admit of a regular progression by columns; and made it impossible for the troops to preserve their designed arrangement and order. 'The guides were much embarrassed, and the columns, by crowding upon one another, were in some measure disordered and broken.

LORD Howe was in the front of the centre column, having major Putnam with him. The advanced body of the enemy amounting to about five hundred, who had retreated from the breast work, began a skirmish with the English troops on the left. Attentive to every circumstance that concerned the troops, Howe enquired of Putnam, "what the firing meant." "I kno wnot, said Putnam, but with your lordship"s leave, I will go and see." "I will go with you," rejoined the gallant young nobleman. Putnam endeavored to dissuade him, and made this remark; "My Lord, if I am killed, the loss of my life will be of little consequence, but the preservation of yours is of infinite importance to the army." His lordship made this reply:

$$
\text { vor. I. ' B } 3
$$


"Putnam, your life is as dear to you as mine is to me, I am determined to go." One hundred of the van under Putnam, immediately filed off with lord Howe. 'They soon fell in with the left flank of the enemy's advanced par$4 \mathrm{y}$, and their first fire proved fatal to his lordship. Thus fell this gallant young nobleman, unspeakably regretted by all who knew him.

$\mathrm{H}_{\text {Is manners }}$ and his virtues had made him the idol of the army. From his first arrival in America, he had accommodated himself and his regiment to the peculiar nature of the service. He cut his hair short, fashioned his clothing, and divested himself and his regiment of all superfuous baggage, that they might not be entangled by the woods, or be easily captured by the Indians. "Exemplary to the officer, a friend to the soldier, the model of discipline, he had not failed to encounter every hardship and hazard." Such were his virtues and ser. vices that the province of Massachusetts, moved by gratitude erected a monument in Westminster Abbey, as a testimony of the regard and affection which their officers and soldiers bore to his memory.

Nor was his death without its infuence and ase. Putnam and the troops which saw him fall, moved on with an animated determination to avenge his death; they cut their way obliquely through the enemy's ranks, and being joined by some other parties, charged so furiously in the rear, that nearly three hundred of the enemy were killed on the spot, and one 
hundred and forty eight were made prisoners. In the mean time the English columns, huving lost their order in the wood, became embarrassed and perplexed ; and the troops were in danger, and in a few instances had already fired on eneh other. The general, perceiving their fatigue and disorder, thought it advisable not to spend the night in such a situation, but to march them back to the place where they had. landed.

Tн в next day colonel Bradstreet was sent to take possession of the saw mills. W With a detachment of one regiment of regular troops, six companies of the royal Americans, the batteau men, and a body of rangers, he tcok possession of the post without opposition. This post being secured, the general again, advanced his army against the enemy

"T $\mathrm{H}$ E fort at Ticonderoga was in a situation favorable for defence. On three sides, the fortress was surrounded with water; on the fourth, nature had secured it with a dangerous morass, which could not be passed without much dificulty. The fort was secured with a breast work eight feet high, planted with artillery. The ground before it was eovered with an abattis, or large trees eut and disposed for defenee. Much labor had been employed to sharpen, interweave, and project their branches, so that they could not be passed or removed without difficulty and time. The prisoners which lad been taken, informed general Abercrombie, that the force of the enemy consisted of eight battalions, with a body of Canndians and ludians, amounting in the whole to six thousane men. That another body of troops of three thousand 
men had been cletached under the command of M. de Levy, to make a diversion by the way of Mohawk river, and to invade the English settlements in that quarter; but that these troops upon the intelligence of Abercrombie's approach had been recalled, and direeted to join the force at Ticonderoga : And that the troops already there, were encamped before the fort, and constantly at work in making formidable entrenchments, which they meant to pursue till the reinforcements should arrive.

ABERCROMBIE wished if possible to take decisive measures to reduce the garrison before the arrival of M. de Levy with his troops, or any other succours should be thrown into the place. It was found that it would be the work of time, to reduce the place by a regular siege; that it could not be done, till they had overcome the difficulties of ciragging their battering cannon over grounds almost impassable; till they could make approaches, and erect batteries in places covered with thick woods; that the trees must be cut arway, roads be opened and many works erected, beforc they could invest the place. To gain further information, Abercrombie sent his engineer early the next morning to cross the river opposite to the fort and reconnoitre the enemy's situation. 'The engineer, upon his re. iurn, reported that the entrenchments of the enemy were unfinished; and that it was his opinion, that the place might be attempted with musquetry, with a good prospect of success. Abercrombie depended on the intelligence of his engineer, and conchuded to adopt his advice. HAvrNG determined apon the meanure, the 
disposition was made for the attack, and guards placed at the saw mill, and landing place. The army was then put in motion, and it marched on to the assault in regular order, and with an undaunted resolution. The enemy instantly began their defence by a well directed and terrible fire from their artillery. "The British sus. tained the shock without being staggered, and still advanced till they were stopped and entangled by the abattis. Their next attempt was to cut their way through these obstacles with their swords; but this, they found impossible to effect, with such weapons. Still they persevered in attempting to force, a passage, and soine of them made their way through all oppo. sition till they mounted the parapet. For more than four hour's the troops continued this method of assault, without being able to open a passage to the entrenchment. All this while they were exposed to a heavy and fatal fire from the cannon and musquetry of the enemy; who were so well covered by their works, as to be exposed to little danger while they kept up an incessant and well directed fire upon their assailants. The general had seen his troops continuing their attack upon the enemy for several hours without any prospect of success, in the midst of a most fatal fire; he now judged it necessary to order a retreat, and the army returned to their former camp without being pursued or molested by the enemy.

Tin loss sustained by the enemy in this affair was not great; and most of those who had fallen were shot through the head, cvery other part of the body being defended and concealed 


\section{by :their works. The loss in the English army amounted to eighteen hundred men, killed and wounded; and two thousand and five hundred stand of arms were taken by the Trench.}

* General Abercrembic's account of his expedition againt Ticondcroga,

\section{"Camp, at Lake Gcorge, July 12, $175^{8 .}$}

THE embarkation of the artillery, fores aud provifions being compleated on the evening of the $4^{\text {th }}$ inflant; next morning at break of day the tents were ltruck, artil all the trooys, amounling to 636 y regulars, off. cers, light iufantry, and langers included, and $902+$ provincials, iucluding officers and batteau men, embalkeu in about goo butteaux, and 135 whale boats, the artillery to cover our landing, being mounted on rafts.

At five in the evening, reached Sabbath Day Point (35 miles down the lake) where we halted (ill ten, then got under way agrio, and proceeded to the landing place (a cove leading to the French advariccd guard) which we reached early next morning, the 6 h.

Upon our arrival, fent out a reconnoitring party; and having met with no oppolition, landed the troops, formed them in four eolumrs, regulars in the centre, and provincials on the Ranks, ard rarched toward the enemy's advanced guard, compored of one battalion, potied on a logged eamp, which, upon our approach they deferted, fint festing fire to their tents, and dentroyingevery thing they could; but as their retreat was very precipitate, they left feveral things behind, which they had not time cither to burn or carry off. In this camp we likewife found one prifoner and a dcad man.

The army in the foregoing order continued their march through the wood nn the wett fide, with a defign to inve? Ticonderoga, but the sood being very thick, imoaffible with any regularity io luch a boo'y of mer, and the guides unfli!ful, the troops were bewildered, and the columos broke, falling in one upan another.

Lord Howe, at the head of the rigt centre column, fupported by the light Infantry, being aovanced, fell in with a French party, fuppofed to conf $\Omega$ of abuut 400 regulars, and a few Indians, who had likewife lol themfelves in the retreat from the advanced guard; of thefe our Alankers killed a great many, and took is\& prifoners, among whos were five officers and three cadets.

But this fmall rucce!s colt us very dear, not as to ire lofs of numbers for we had only two offecrs killed, but as to confeguence, his iord?hip being the firt man that feli ir this fi: inith; and as he was, very defervedij, univerfally beloved and refped d hroughout the whole army, is is eafy to conceive the grief ard confternation his untimely foll occalsoned; for my part, I cannot heip owning that I feit it mott hcavily, and lamen: ijim as finccrely.

The rth, ahe troops being grcatly fa: iqued, by liaving been cne whole night on the water. the following day conlanily on foat, and he nevi day uncier arms, added to their being in want of provilion, having dropped what they had brougle with then, in order to lighen themfelves, it was thought acivifeable !o return to the landing place, which we accordirgly did about eight that momiog. 
Every corps which had been engaged on this unfortunate occasion, had behaved with a steady coolness and intrepidity ; and suffered very severely. But the heaviest loss fell on the regiment of Highlanders, commanded by lord John Murray; one half of the privates, and twenty five officers of this regiment were either slain upon the spot or desperately wounded.* So heavy and severe a loss seems to have determin. ed the English general to withdraw his army

Abont eleven in the forenocn, fert of Licut. Col. Bradnrest, with the ath regimont, lix companies of the firn batialion of the royal Americams, inc batleau men, and a body of rangers and provincials, to take polferfion of the Saw Mill, within two miles of Ticonderoga, which he foon effected: as the enemy who were polled there, aleer defroying the mill and breaking down their bridge, had retired lome time before.

Licuteriant. Colonel Braditrect having laid another bridge acrols, and beving fent me natice cf his bsing in poteffion of that ground, I accordingly marched thither with the troops, and we took up our quarters there tirat night.

The prifoners we had taken biag unarimous in their reports, that the French ha: right batia!ions, fome Canadians ad colony troops, in all about 6oon, encamped before their fort, who ivere intrenching themfelves, and throwing up a breal work, and that they exp:Eted a reinforcement of 3coo Canadians, bafices lndiane, who had been detached under the com: inand of Monfieur de Le\%, to make a diverfion on the fide of the Mo: hawk rive:; but upon intsiligerce of our preparatione and near spproach, had been repeatedly recalied, and was hourly expectid; it wes thought mot advilable to loie no time in making the attack; wherefore early in the rinoming of the $8 \cdot h, 1$ fent Mr. Cielk, the engineer, acrofs the river on the oppoitie fide of the fort, in order to reconnoitre the enemy's intrenchmenis.

Upon his return, and favourable report of the pratticability of carrying thoie works, if atlacked before they were finified, it was agreed to ftorm them that very day : Accordingly the :angers, light infantry and the right wing of Provincials, were o:dered inmediateiy (1) march and poft them: fclies in a line, oul of csmon fho: of the intresichuents : the right extending to Lake Goorge. and ine icft to Lake Chanplain, in order that the regular troops, dellired for tha attack of the intrencisments, might foras on their rear.

The Piquete were to beyin the attack, fufaincd by the grenadiers, and by the batalions : the whole were ordered to march up brilkly, ruih tipon the enemy's fice, and noi give theirs, until tiey were withis the enemg'o brealt work. 
from this scene of carnage and havoc; they reembarked in their batteaux, and returned to their camp at lake George with such expedition; that they regained their former situation the evening after the fatal action.

If general Abercrombie was not blameable, he was at least extremely unfortunate in this fatal affair. The information and advice that he received from his engineer was greatly errone. ous and faulty; and it should seem that a little enquiry would have been sufficient to convince the general, that the works at Ticonderoga could

After theie orders ifued, the whole army, except what had been left at the landing place to cover and guard the batteaux and whale boats, and a Provincial regiment at the Saw Mill, were put in motion, and advanced to Ticonderoga, where they unfortunately found the intrenchnents, not onily inuch Atronger than had been reprefented, and the breaft work at leaft eight or nine feet bigh: but likewife the ground hefore it covered with felled irees, the branches pointed outwards, which fo fatigued and retarded the advancing of the troops, that notwithftanding all their intrepidity and bravery, which I cannot too much commend, we fultained fo confiderable a lofs, without any profpect of Eetter fuccels, that it was no longer pruden: tó remain before it ; ann it was therefore juckged neceffary, for the prefervation of the remainder of fo many brave men, to prevent a total defeat, that we thould make the beft retreat pofible: iccordingly, after fevewl repeated attacks, which lafted upwards of four hours, under the pholf difadvantageous circumfances, and with the lofs of 464 regulars killed, 29 milling, $111 y$ wounded; and 87 Provincials killed, 8 milling, and 239 wounded, officers of both inciuded, I retired to the camp we occupied the night before, with the broken remains of fevera! corps, fending away all the wounded to the batteaux, about three miles diftance; and early the next morning we arrived there ourfelves, cmbarked, and reached this place the evening of the 9 th. Inmediately afier my return here, 1 fent the wounded officers and men that could be moved, to Furt Edward and Albany."

The Freuch, in the account which they pathlifhed at Paris in Septem. ber, gave a very different but not a probable account of this rencounter. Their own forcs was flated to confift only of 2800 French, and $45^{\circ}$ colony troops, ander the marquis de Montcalth; with 400 chofen men under the chevalier de Lcvy, that had joined them only on the 7 th in the evening. The lof of the Euglion is reprefenied at 4000 killed and wounded; thist the Frencli loft that day only $I_{2}$ cficers and $9^{2}$ foldiers, killed; and $24^{2}$ feldicrs wounded. Their lofs in the fkimith of the oth of July, is thus fated, a captain and made prifoners; and 18 , Caliadians kilied or taken: And that the

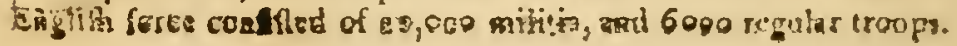


not be carricl by a coup de main. Had he continued the assiult, there can be no doubt, but that he would have lost almost the whole of his army. If the assault was rash and precipitate, the retreat seems to bear the marks of unnecessary intimilution and lurry ; for it is difficult to conceive what danger there could have been, in commencing a regular siege with troops, who had discovcrest such courage and resolution as appeared in the assault. We ought however not to be very positive in passing our censures on men and messures, where all the circumstances and motives are but imperfectly known. The censure of mankind almost aiways follows misfortune. Thus it proved in the present case; the attempt to cary the place by storm, was considered as a rash and imprudent measure; and the retreat was condemned as pusillanimous and unnecessary.

NOTWITHSTANDING his defeat and mortification, Abcrcromivie did not let the season pass away without further attempts in fayor of tho colonies. Brigadier general Stanwix was sent with a considerable body of provincials, to erect a fort at the carrying place at Oneida; and thus secure a passaçe on the Mohawk and Onondago rivers to $\mathrm{B} s w \mathrm{~g}$. This business was properly cxecuted, and thit important post secured; a measure which proved greatly beneficial in the ensuing campaigus.

CozONAL BrADSTEET had projected an expecition against Cadaranui, or fort Frontenac. This fort was situated on the north side of the river St. Lawrence, just at the point where the river derives its origin at like Ontario. A. VOI. I. 
gainst this fortress, Abcrcrombie dispatched Bradstrect wih three thousand men, chiefly provincials. He marched his troops by land to the waters of lake Ontario, and embarked thence in some sloops and batteaux provided for the purpose, and landed within a mile of fort Fron. tenac. The enemy had no intelligence or expectation of his approach, and were poorly prepared for defence. The garrison consisted of but one hundred and ten men, with a few Indians; and could do no otherwise than surrender at discretion. 'The fort itself was not of much strength; but it was valuable on accomt of the immense quantity of military stores and merchandize, which it contained. Sixty pieces of cannon, sixteen mortars, and a quantity of small arms were found in the fort. What was more valuable, a large quantity of provisions was also captured; these had been deposited at $\mathrm{Ca}$ daraqui, for the use of their western garrisons, and Indian allies; to supply the Franch troops that were gone to the Ohio, against brigadier reneral Forbes; and for the subsistence of $\mathrm{M}$. de Levy and his troops, on their expedition on the Mohawk river. In addition to all the military stores and provisions there was also an immense quantity of merchandize, for the purpose of trade with the Inclians, and to supply their own forts and settlements. Besides the forts and stores, Bradstrcet made himself master of all the enemy's shipping on the lakes; these amounted to nine armed vesscls, some of which carried cighteen guns. Having carried the fort without any loss of men, Bradstreet, in conformity to th:e general's orders, destroyed the 
works, with all the magazines and stores; and immediately returned with his men to Oswego, taking with him two of the enemy's vessels.*

Nothin had yet been done upon the lakes, during the whole course of the war, which had so much affected the French interest as this exploit of colonel Bradstrect at Cadaraqui. Fort Frontenac, by its situation, had the entire conmand of the orisin of the river St. Lawrence. It was the grand magazine of military stores and provisions, for all their western posts and. settlements, and for their Indian allies; it commanded the passage into all the western lakes, and was the grand emporium, where all the savage nations collected to transact their business of trade, and to consult with the Freneh on the afiairs of war. The unexpected and total destruction of this place not only ilarmed and surprised the French, but it carried dismay and terror to their Indian allies; who had never scen such a sudden and extensive destruction, carrice

* Colonel Bractotreat's Letter to Genezal Amhern, on the reduction of Fort Fronterac.

Cswcgo, Augtist 31, 1758 .

1 landed with the troops withir a mile of fort Frontenac without ojposition, the 25th. The garrion surrendered prisoners of war the $27 \mathrm{th}$, between 7 and 8 in the morning - It iras a square fort of 100 yards, the exterior side, and had in it 110 men, come women, children, and Indians; 6 ? picces of cannos, (half of which were nowuted) sixteen small mortari. wich an immense quantity of provision and goods, to be sent to the troops tone to oppese Brig. Gen. Forbcs, their : "estern garrisons, Indians, aud to support the army under the command of $\mathrm{M}$. I. evy, on his intended enterprise against the Mohawl river, valueu by the Frelicli at 800,000 livres. We have likewise taken 9 vescels from 8 to 18 gurs, which are all they have upon the lake, tw $\approx$ of which I have brought here; one richly laden; and the rest and the provisions ihave burut and destroyed, together with the fort, artillery, stores, \&e. agreeitble to your excellency's instructions, should I succeel. The garrison made no scruple of saying, that their troops to the southward and western garrison will wufer greatly, if not entirely staive, for want of the provicions and ressels we have destroyed, as they have not any left to bring them hone from Niagara. The terms ou which the garrison surrenderod were prigones of $42 \mathrm{r}$, wrtil cuclanged for cyual numbers and rakk. 
with such secrecy and dispatch, into the French country.

The success of Bradsireet at Cadaraqui, was not without its effect on the feelings and move. ments of the Indians, on the Ohio. In the beginning of July, brigadier generai Forbes began hismarch from Philadelphia, for fort Du Quesne. The fort stood on the confuence of the Monongahala with the Ohio river. With incredible difficulties, through a vast tract of cruntry, but little known, without roads, through mexplored mountains, morasses and wcods, he had penetrated with the main body as fir as Pays-town, at the distance of ninety miles from fort $\mathrm{Du}$ Quesne. He had sent on colonel Poucuet, with two thousand men, fifty miles further, to a place called Ly;1 Henning. Bouquet had detached major Grint, at the bead of eight hundred men, to reconnoitre the fort and works at the Onio. 'The enemy having inelligence of Grant's upproach, sent fomard a much larger body to intercept and sumound him. A sevre action took place, which the English suported with much courage and resolution for three hours, but at length were obliged to reict to the superior numbers of the enemy. "Plrce hundred vere killed or takcin by the cump, anorgo whom was major Grant, the commander; he, and nineteen of his offecrs were curict priso:crs to fort Du Guesne; the remaincer of his troops fought their way back to Brequet. Forbes was not dismaycel by this morifying check, but still advanced with much cutition, and a steady perseverance. The cncmy having watched his motions, and obscred the circula. 
spection and vigor, with wheh he mace his advanecs, conchnded lest to abide the hazaril and event of a s ics; fin dismantled and aban-

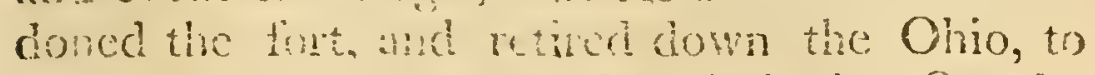
ther sctenents an the Jississippi. On the tweity fouth of forcmorntiney quitted the fort and the next day it whe talea pessession of by

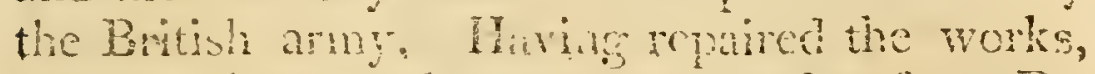
forbes cinaged the name of the fort from $\mathrm{b}$. Quesne, to that of Presburg, mich it silit benirs.

Sucir were the eronts of the compaign of 1758. Whe expedition agunst Lousbourg, Forts Frontenc and Du Quene, ind complutIy succeded. "Ihat aranst Piconderogit har faifed. The events of the campeng? lad beein much in foror of the britsh interest; and the arrantores thet hed becis dxance over the Frenci, gurefintering hopes and propects that they migh be prowed to moch greater atrantage, in the conse of anoher year. Gonom Anhersthd now assumal the command, and the pubic oxpctation and feching reve ready to afrord any assistune thet he should ask. This general was ancoly preparing for the rext comprign. Soon afure hac compleated the cunguest of Cape Buton he received inteligence of the defent of Abercrombie at Miconderogra. Lcaving a strong gamison dî̀ Jonis. buarg, he enbuticel with sa reghents, and landed at Boston. About the midlc of September, he began his march for Albany, to join the troops at the lake ; 10 attcmpt any further cnterprise, or to be in readiness for the ricx campaign, as the season and circumstances should permit.

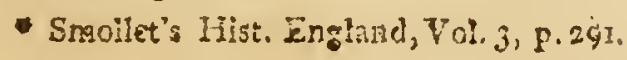




\section{CHAPTER XIII.}

War. Progress and cucnts of the riar in the yeas 1759 and 1760. Plan of the campainn for 1759. Conquest of Quebec by genersh Wholfe. Capture of Ticonderoga and Crozun Point by general Amherst. Expedition $a$ gainst the Indian village of St. Francois by major Rogers. Proceedings on lalie Chamiplain. Capture of Niagara by General Johnson. Raflections on the campaign of 1759. Measures of Vandicul cot Montreal in 1760. Plan and proceerimgs of general Amhersi. General Mluray's defeat at Quebec, and arrival at Montreal. ITariland's arival at the river St. Lancrence. Gutitulation and surrensler of" Cancatic to gencral. Anherst. Reflections on the origin of these rasts. Their effects on the morals, literature, popnitusion, seithement and political state of the colonies.

1759. FROM the advantages that had becn already obtained over the rench, the British ministry had beer lead to expect that the compleat conquest of Canada might be effected in another compaign; if their ticops were cmployed so as to divide the enemy's for. ces, and to make their impressions on different parts of the country at the same time. In pursuance of this plan the Brisish minister, PIтt, had projected three expeditions against Canada. Gencral Wolfe, who had been so much distinguished in the siege of Lowisbourg, was to procect ap the river Si. Liawence with a body of ingt thousand men, as soon as the river should 
be clear of ice, and lay siegre to Quebec, the capital of Canada. General Amberst, who was commander in chief, was to proceed with an army of regular troops, and provincials, amounting to twelve thousand; and attempt the reduction of 'Ticonteroga and Crown Point, and thence proseed through lake Champlain and the river Sorel, to the assistance of Wolle. At the same time brigadier general Prideaux with a third body, reinforced by the Indians under the influence and command of sir Willitm Johnson, was to invest the French fort at Niagara, and endeavor to reduce that important fortress. It was concluded, that while all these forces were making their attacks in different clirections, they would all serve to assist each other; and at the same time to divide the forces, and embarrass the councils of the enemy.

The plan itself was marked with the energy and boldness of the minister's genius. The nuvigation of the river St. Lawrence had ever been viewed as very diflicult and dangerous for a fieet. The city of Quebec was strongly fortified by nature and art, formidable on account of the number and bravery of its inhabitants, and in a situation in which it could not be much injured by a fleet, or approached but by a strong army by land. The marquis de Montcaln was a greneral of much courage, activity, and experience ; already famous for his exploits, and success against the English. This offeer had taken his situation between Quebec and Montieal, with an army of ten thousand men, consisting of regular troops, and wcll disciplized militia, reinforced by a linge number of armed 


\section{\&O NATURAL AND CEYII}

Indians. An army of reserve hovered round Nontreal, the residence of $M$. cle $V$ iturlicul; the commanter in chicf, and governor senewal of Canada. Whe fort at Niggara wats mell buits and fortified, and contained at somison ef six hundred men; the roact to which, wis lows, embarrussed, and unexplored. Na de Levy vas also at the head of a ning detachment, acguanted with the wooris and paseses, scunriug the country in all direcions; and angmented by new recruits, as occasions and circunstances reguired. And eveny preceding attempt had sherw the dificulty, the rlanger, and the ill suecess, of an expedition atrainst Quebec, or $\mathrm{W} \mathrm{i}$ conderoga. Aware of these dificulties, but animated by the genius of Mr. Prtr, the British colonies and troops cniered with energy and zeal upon measures, that rather bore the appeamence of danger and defeat, than of probabil. ity and success.

The most dificult part of the business, and the great object to which all the other opera. tions of the campaign were suborlingte, was the conguest of Quebed. This expectition had been committed to the care of migr generwl Wolle; a young offece of great enternise and resolntion, and of a superior military senivis. He was assistcd by the brigadice sucmals, Momkton, Townhend, and Aurray ; of cers of distinction, family, and much cxpericnes, thongh yet in early life. The souadron designed for the service was pot und the command of Actmirals Sandus and Holmes, who hat on several occasions before signalized the ir courage and cont duct in the arvice of the contry. The fiect 


\section{HISTORY OF VERMONT.}

tailed from Eingland about the middle of February, and was in sight of Lonisisourg so early as the lwenty fiest of April ; but the harbor being blocked up with ice, the flect bore away for Halifix. As soun as the scason would permit, the troops were cmbarked, and the fleet sailed up the rivor S. Liwrence, without meetance with any of those difficulties or perils, which they had been taught to expect. Towats the latter end of June, the whole army was safely landed on the iste of Orlens, a little below Quebec, without any cpposition, or having met with any disater.

From that time till the beginning of September, general Wolfe was struygling without prospect of success, against cvery kind of dificulty, in an cneny's country, against a city strongly fortified by niture and art, defended by an army more numerous than his own, command d by Montcalm, whose military talents and expioits had already rendered him famous and formidsbic to the British colonits and generais. In adcition to other dificulties he had received a severe check, anl lost above five hundred of his men, in an attack which he made on the eneniy at the falls of Mntmorenci. A fever and a dysentary were wasing his own strength, and for a time he becane wable to attend to business.

Almost desparing of success, it was the opinion of his generdi ofiners that there was no prospect of sacceeding, unless they could carry the troops above the town, effect a landing on the morth share, and bring the enemy, if possi-

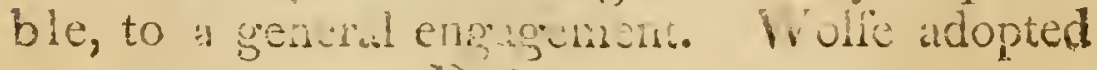

$$
\text { vOL. I. D } 3
$$


the opinion as a matter of extremity and necely sity, and began the measures that were neces. siry to carry it into execution. After a series of the most uncommon difficulties, and judicious manœurres, by the most dexterous address, and well concerted movements, he succeeded in effecting a landing near Sillary on the twelfth of September, an hour after midnight. Wolfe himself was with the first party that landed; and in an instant all was activity, enterprise, and expedition. The troops' that were first landed, climbed up the bank and precipice, by the bushes and boughs of trees, with the most. animated agility and resolution; they dispersed a captain's guard who were placed there to defend the narrow path of ascent, and gained the summit without any further 'molestation from the enemy. Wolfe climbed up among the rest ; and as soon as he had ascended the banks, drew up his troops in order as fast as they arrived.

MONTCALM was no sooner informed that the British troops had gained the heights of Abraham, which in a manner commanded the town in its weakest part, than he resolved to hazard a battle, and having collected his whole force from the side of Bcauport, began his march without delay. Both armies were soon drawn up in order of battle, with their respective generils at their head. Wolfe had piaced himself on the right of the Einglish; Montcalm was on the left of the French arny: Thus the two generals, rivals worthy of each other, met at the hend of t' eir respective amics, where the confict was the most severe. About nine o'clock the French army advanced to the charge in 
good order, and with vivacity ; but with an irregular and not well directed fire. The British reserved their fire, till the enemy had approached within forty yards of their line; then they poured in a terrible discharge, and kept up their fire with great deliberation and spirit. The contest for a few moments was dreadful; both generals were determined to conquer or die; and their armies knew that on the event of an hour, the fate of Quebec depended. The French were unable to stand the impetuosity and fire of the British but for a short time; and the battic soon terminated in the entire defeat and dispersion of the French army. Wolfe* and Montcalm* both fell at the head of their troops, and the British were left compleatly masters of the field, under brigadier general 'Townshend. Five hundred of the enemy were slain on the field of battle, and about one thousand were made prisoners ; of the British, fifty men were killed, including nine officers, and as many as five hundred were wounded. Dispirited by the event, and disheartened by the loss of their able and favorite general Montcalm, the French were in great consternation; and on September the eigiteenth, De Kamsay, the officer on whom the command had devolved, signed articles of capitulation, and surrendered the troops and the city to admiral Sanders and general Townshend. Thus was effected the conquest of the city of Quebec. For seventy ycars the English had been attempting to reduce this place. The force that was sent against it in the year 1711 , was

- Appendix, No. VIII.

t Appendix, No, IK." 
fully equal to that which was now before it. The force that Wolfe comnianded did not ap. pear adequate to its reduction, and it was deknded by the greatest genemil the Fronch had ever employed in Cannda. The genius of $M^{\top}$ olfe succeeded in defeaing their gencral, and sub. duing their capital.

WHIL these scenes were taking place at Quebec, general Amherst had no information of the procecdings in that quarter, but was busily employed in pushing forwand the expedition on lake Champirin. So many difficulties occurred to retarci the operations of his arny in that unsettled purt of the country, that the summer was, already fur adianced, before he could pass lake George with his troops and artillery. Aware of the danger of supprise, and not mmindful of the disaster that the British troops had sustained the year before, this able and judicious officer proceeded with the greatest circumspection; leaving nothing to chance, but making provision for every difficuly, or opposition, that could be foreseen. At length, in the latter end of July, he arrived in the ricinity of "Iiconderoga, with his army of regulurs and provincials, in excellent order, and amply supplicd with artillery, mility stores, and provisions. The etemy hod watched all his motions, and been very attentive to find an opus tunity to getin some advantage; hut they liad not ventured to matie any opposition to his troops, either when pus. sing the lake, or efecting tieir landing. Having passed the lake and landed his stores, Antherst immediately began to make preparation to re. duce the fortress by a regular sigge. At first 
the enemy appeared to be resolute to hold their works, and to make a regulur defence. 'Tiny soon found that they had an able officer to op. pose; that Amherst was cautious, resulute, well prepared for undertaling the siege, and not disposed to subject any thing to unnecessary risk or hazard. Despairing of success by any surprise, or extraordinary exertions, and hiving orders to retreat from place to place towards the centre of operations at Quebec, ratier than to run the risk of diminishing the French force by surrendering prisoners of war, they set about dismantling the fortifications; and having doine some small injuries to the rorks, they abindoned them on the night of the twenty seventh of July, and repaired to Crown Point; leaving their heavy artillery, several sunken boats, and the works but little damaged though on fire. The same day, Amherst took possession, and encamped within the French lines. This important acquisition was effected without much opposition or bloolshed : It was however mark. ed with the loss of colonel Roger Townshend, a very accomplished young officer, who was killed by a cannon ball as he was reconncitering the fort. This young nobleman much resembled the gallant lord Howe, in the circumstances of birth, age, character, and uscful qualifications. He fell near the same spot, where that young hero was slain the year bef're.

HAVING succeered in his attempts aginst Ticonderoga, Amberst began to repair and en. larse the fortifications; and to prepure his butteaux and other vessels for an cxpedition ar gainst Crown Buint. Scouting and ranging 
parties were constantly cmployed, hovering in the neighborhood of that place, and watching all the measures and motions of the enemy. One of these particas returned to the English camip on August the first, and brought intelligence that the French had also ibandoned Crown Point, and were gone down the lake, without destroying the works. Amlerst detached a body of rangers to take possession of the place; and on the fourth of August embarked with his army, landed the same day, and placed his troop. within the enemy's works. 'Thus was effected the reduction of 'Ticondero. ga and Crown Point. From the time of their first crection they had given security to the inroads of the eneray, afforded an asylum to the scalping parties that had infesterl the frontiers of the whole country, and cost the British colonies immense sums of money and many thousands of her citizens. They now fell by the attack that Woife was making upon Quebec, and by the caution and resolution that Amherst displayed in the approach and mancuvres of his army. No sooner was their conquest compleated than Amherst superintended the works, strengthened and enlarged the old ones, and began a new fort; meaning to make cfiectual prorision that the enemy sinould never aguin chtain possession of a post; which had been so dangerous and distressing to the British provinces. "

WuE French troops, after the evacuation of Crown Point, retircd to the Isle Aux Noix. Whis island is at the north end of lake Cham. pluin, about five leagues to the south of St. 


\section{HISTORY OF VERMONT.}

Johns; and being situated in the midst of the stream, effectualiy commands the passage into Canada, in that quarter. At this place, M. de Burlemagne had collected a force consisting of three battalions, and five piquets of regular troms and a body of Canadians and marines, amounting in the whole to three thousand and five hundied men; provided with a numerous artillery, and erery requisite for defence. The lake was defended by four large vessels, mounted with cannon, and manned with piquets from different regimenis ; under the command of $M$. le Brass, a captain in the French navy, assisted by M. de Rigel, and other sea officers. With this force, M. de Burlemagne encamped and fortified at the Isle Aux Noix; medning to make a stand against the British forces. And Amherst could not proceed down the late rill he had constructed a naval force superior to that of the French.

In the mean time it was thought best to make the enemy fecl the force and resentment of the English colonics. The Indians had not as yet discontinned their atempts to disturb and distress the frontiers. Among these tribes none had been more bloody and cruel than that of St. Francois. Their villdge was situated on the south sicle of the river St. Lawrence, not far from Trois Rivieres. So eariy as the year 1703, the grovernor of Canada had drawn off a lurge number of Indians from Penobscot, Norrige. wock, Saco, Pigwacket, and uther parts of the eastern country and settled them at Bccancour and St. Francois. By uniting them with the In

* Smollet's Hist. Easiarich, Vol. 3, p. 4 \% 
dians of Canada, he meant to procure a force suf: ficient to protect their own frontiers; and to h.lve always in reserve, a body of savages well acquainted with the English frontiers, and the most favourable times and places of carrying disolation among them.* The event justified his expectations. From none of the Indian tribes had the provinces of New-Hampshire and Massachusetts suffered so much, as from the savages of this village and tribe. They made their incursions through the river St. Francois to lake Memphremagos, and from thence down Connecticut river to the English settlements: and had been much distinguished by the slaughter and destruction they had spread among the advanced setrlements, by the number of their scalps and captives, and by the enormity of their cruelty and barbarity.

ivejor Rogers was appointed by general fimherst, to munage an excursion against this barbarous tribe and to eary the horrors of war into the midst of Cinada. liogers was from the province of Neri-Hampshire. He commanded a company so early as the year 1755 ; and had become so famous for the number, boldness and success of his enterprises, that lord Loudon had set him at the huad of the ranging companies, put him upon the British establishment and pay, till he rose to the rank of a major. Amherst esteemed him a pirsper person to retaliate on an Ixlian village, sme of the measures they had s) often acter, against the advanced Einglish for's and setdements. The ordurs which he

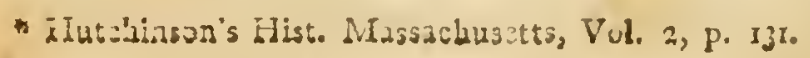


gave to Rogers, were expressive of the character and views of the English general; and of the sentiments and feclings of the English colonies, with respect to the Indian cruelies. *

In comrinity to his orders, Rogers set out with two hundred men in batteaux, and proceeded dowa l ke Champlain. On the fifti day after they ieft Crown Point, they met with a misfortune which diminisher their numbers. Being encamped on the eastern shore of the lake; a keg of gun powder accidentally took fire, which in its explosion wounded a eaptain of the royal regiment, and several of the men. These were sent back to Crown Point, with some of the party to condust them; by this event the party was reduced to one hundred ind forty two men, officers included. With this reduced party, the major proceeded on the expedition, and in seven days landed at Missiscoe bay. Here he concealed his boats among the bushes that hung over one of the streams, and left in them provisions sufficient to carry them back to Crown

\section{* "Orders from Sir Jefirey Amherst to major Rogers.}

"You are this night tr set. out with the detaciment as ordcred yesterday. - (viz. of two hundred mes.) and "procevd to Missiscoe Bay, from - whence you will march and attack the eneray's settlements or the snutb 'site of the river St. Lawrence, in such a mavncr as you shall judge ' most eftectual to disgrace the enemy, and for the success and honor of " his Majesty's arms.

"Remember the barbarities that have been committcd by the enemy's 'Indianscoundrels, on every occasion where they have had an oppertunity - of showing theirinfazous cruelties on the Ning's subjects; which they - have done without mercy; take your rcvenge; bur do not forget that - thiugh these villains have dastardly and promiscuousiy murdered the ' women und chicheu of all orders, it is my orders that no women or chil' dreil be killed or hurt.

"Whea you have executed yourintended service, you will return with "yourdetachment to camp, or to join me wherewer he arny ma be.

\section{- Yours, z:c.}

"Camp at Crown-Point, Septenaber $I= \pm 750 . "$

J1:XEREP AMEERST:

Eincs' Military Dictionary-4it. Trearevere.

$$
\text { vol. I. Ii } 3
$$


Point. Two of his rangers were appointed to watch the boats, and to keep themselves concealed till the party should return; or if the enemy should discover the boats, to pursue the trac:: of the party with the greatest speed, and give intelligence to the commander. The second evening after Rogers left the bay, the two trusty rangers overtook the party, and informed. Rogers that four hundred French and Indians had discovered the boats and sent them arvay with fifty men; and that the remainder were in pursuit of the English party. Rogers kept the intelligence to himself; and ordered a lieutenant, with eight men and these two rangers to proceed to Crown Point; inform the general of what harl taken place, and request him to send provisions to Coos (now Newbury) on Connecticut river, by which he meant to return.

Noтнing now remained for Rogers but to give up the expedition, or to outmarch his pursuers. He determined on the latter, and push. ed forward for St. Francois, with all the expedition that was possible. On the fourth of $\mathrm{Oc}$ tober, at eight o elock in the evening, he came within sighe of the town. Ordering his men to hait and refresh themselves, he dressed himself in the Indian garb, and took with him tro Indians who understool the language of the St. Francois tribe, and went to reconnoitre the town. Fe found the Indians engaged in a grand dance, and without any apprehension of danger. At two o'clock in the moming, he returned to his detachment, and marched them to the distance of about five hundred yards from the town. A. bout four o'clock the Indlians broke up their 


\section{HISTORY OF VERMONT. AISI}

dance and retired to rest. Rogers waited till they were asleep, and at break of day, he posted his men in the most faverable situation and made a general asæault.* Compleatly surprized, the Incians were soon subdued. Some were lilled in their houses, and of those who atten!pted to fly, many were shot, or knoclied on the head by those who were placed at the avenues. The Indian method of slaughter and destruction was put in practice on this occasion; and wherever the Indiuns were found, their men, women and childreir, were slain without distinction and without mercy. 'The ferocity of the proceed. ings were already extremely violent, but the prospects which appeared at the rising of the sun, could not but add new force and irritation to the feelings and passions of the assailants, As the light appeared, the scalps of several hundred of their countrymen were seen, suspended on poles, and waving in the air. These trophies of savage cruelty and success could not fail to irritate to the highest degree, the passions of the provincial soldiers; they meant to avenge the blood of their frienris and relations, and they spared no pains to make an end of the village, find of all that they could find of its inhabitants. The villagge contained three hundred of the enemy; two hundred were rilled on the spot, and twenty taken prisoners.

PIf $\mathrm{E}$ town appeared to have bcen in a very fourishing state. The houses were well furnished, and the church was handsomely adorned firth plate; the whole village had been enriched

* Stmęg. Dickixary tild. 
by the scalps, and plunder, taken from the English. 'Two hundred guineas were found in money, and a silver image weighing ten pounds; besides a large quantity of wampum, cloathing, and some prorisions. * Collecting the provisions, and such articles as they could easily transport, they set fire to the town, and reduced it to ashes. At seven o'clock in the morning the affitir was compleatly over; Rogers then asscmbled his men, found that one was killed, and six slightly wounded. Having refreshed his men for one hour, the major made no further delay ; but set out on his return, with the addition of five English captives whom he had retaken; leaving the inhabitants slain, and the viliage reduced to ashes.

To avoid his pursuers, Rogers now took a differelit route, and marched up St. Francois river; meaning to have his men collect, and rendezvous at Coos, on Connecticut river. On their march they were liarrassed by some of the enemy, and several times attacked in the rear. In these rencounters they lost seven of their men, till Rogers, fivored by the dusk of the evening formed an ambuscade upon his own track, and fell upon the enemy where they least expected it; $b_{y}$ this stroke, he put an end to any further anioyance from the enemy. For a. bout ten days the detaclument kept together, tiil they had passed the castern side of lake Memphremagog. It was then thoupht best to scatter into smaller parties, and make the best of their way to some of the English settlements.

* Belknap's Hist. New Hamplíte, Vol 2, p. jo4.

th Simes, itsiu. 
Their sufferings now began to be severe, not only from the excessive fitigues they had undergone, but from hunger. Their provisions were expended, and they were yet at a distance from any place of relief. Some were lost iis the woods, and others perished at Coos, being unable to hold out any further.* But Rogers, with the most of his men, persevered amidst all their sufferings, till they arrived at Number Four, now Chariestown. "This enterprise proved extremely dangerous and fatiguing to the men, who had been engaged in it; but it made a deep impression on the enemy. It carried alarm and consternation into the heart of Canada, and convinced the Indians that the retaliation of vengeance was now come upon them.

Vhile Rogers was thus employed in hum. bling the Indians on the river St. Lawrence, general Amherst was preparing to carry his army against the forts and settlements in Canada. The naval force of the enemy, as yet gave them the command of the lake; the first business of the English general was, to obtain a superiority there. Captain Loring had for some time been employed to superintend the building of ressels at 'iconderoga. Having obtained information of the situation and force of the enemy at the Isle Aux Noix, Amberst directed Loring to build, with the greatest cxpedition, a sloop of sixteen guns, and a radien, eighty four feet in lerith, capable of carrying six large camnon. By the eleventh day of October, these, together with a brigantine were fnished, victualled and nanned

- Belknap. ibra. 
and the general embarked with the whole body of his army in batteaux, to engage the enemy. The next day the weather became tempestuous, and they were obliged to come to anchor in a bay on the western side of the lake, and the men were landed for refreshment. In the mean time, Loring; with his small squadron, suiled down the lake, and discovered the French force : He gave chace to a French schooner, and drove three of their vessels into a bay, where two of them were sunk, and the other was run aground by their crew, who escaped into the woods. One howerer was repaired, and brought away by Loring, who had so far succeeded as to leave but one schooner remaining to the French.

General Amerist, after having been wind bound for several days, reembarked his troops, and proceeded down the lake. The storm which had abated, began again with increased vio!ence, and the batteaux were in danger of being swallowed up by the wares. Finding the season for action was elapsed, and the winter setting in with severity, the gencral judged it impracticable to undertake a new expedition without endangering his army, or running too great a risk of not effecting his object. Returning to the bay in which his troops had been sheltered dur. ing the storm, he lunded then again, and began his march to Crown Pont, where he arrived on the twenty first of October.

Having succeded in gaining possession of two of the French forts, and securing the command of the lake, Amherst's attention was now employed in erecting a new fortress at Crown Point, and three new outworks for its more ef 
fectud defence; in compleating the roads which had been opened cluring the summer; and planning another from Ticonderoga to Number Four c. Charlestown on Connecticut river; his ob. joct was, cfiectually to secure the advantages which he had already olstained; and to put his troops in a situation, favorable to the compleat success of another campaign.**

The expedition to Niagara, had been plit under the command of general Prideaux. This officer, with the troops assigned for the expedition, reinforced by the Indian auxiliaries under Sir William Johnson, advanced to Niagarn without being molested by the enemy; and invested the fort, about the middile of July. The approaches were carried on with nuch vigor till the twentieth of that month, when Prideaux, visiting the trenches, was unfortunately killed by the bursting of a cohorn. The command of the army devolving on Sir William Johnson, he pursued the same rigorous measures, and erected his third battery within one handred yards of the flag. While the English were thus pushing the sicge with the greatest vigor, the enemy were making preparations to relicve the place; and had assembled a bosiy of troops from Venangs, Detroit, Piesque-lisle, \& other settementsin thaturuarter, amounting to twelve hundiced men. "lhese, with a body of Indians under the command of M. d'Anbry, were marching to reminore the garrison at Ningara. Johnson was informed by his Indians that this body w is on their march, and he instantly resolved to 


\section{NATURAL AND CIVIL}

intercept them. In the evening of July the twenty third, he ordered the light infantry and piquets to take post on the left, on the road. leading from the fills of Niagrara to the fort. In the moming, these troops were reinforced with the grenadiers, and by a part of the forty sixth regiment, commanded by lieutenant colonel Massey; the forty fourth regiment, under lieutenant colonel Farguhar, ras posted at the tail of the works, to support the guard of the trenches; and the Indians were ordered and cncouraged to be ready for the contest.

Tirus prepared, the English were ready for the battie, and about eight o'clock in the morning the enemy appeared. The Indians in the English army, advanced to speak to their brethren who were with the Freiach; but the conference was declined by the enemy. In a fery minutes the horrible yeil, called the War-whoop, became the signal for slaughter; and the action was begun with grat impetunsity by the enemy. But neither the Indian shries, nor the French vivacity conld avail; their troops met with a hot reception in the front, and Sir William's Indians fell furiously on their flanks. The shork was too violent to be sustained, and in little more tinan half an hour their whole army was routed. Great numbers were slain, their general and all his officers were taken prisoners, and the pursuit was conthued for five miles, through the woods vith great slaughter.

Whe battle was foingt in the sight of the Irench garrison at Niagara, but the garrison was not aware how grent a loss the Irench amy had sustained. As soon as the defeat of the 


\section{HISTORY OF VERMONT.}

French was compleated, general Johnson sent major Harvey with a flag to the commanding officer in the fort, with a list of the prisoners, requiring him to surrender while he had it yet in his power to restrain the Indians, and before any more blood should be shed. The commanding officer wished to be certain of the event of the battle, and was permitted to send an officer to visit the prisoners. Upon his return, the commander agreed to surrender, articles of capitulation were proposed; and in a few hours the treaty was ratified and signed; the whole was compleated about ten o'clock in the evening of the same day, on which the battle lad been fought. 'The garrison, consisting' of six hundred and seven men, were to be prisoners of war, and protected against insult and pillage from the Indians; the women, at their own request, were to be conducted to Montreal; the sick and wounded were to be treated with humanity, and sent to their respective corps as soot as they were recovered.*

THIS was the second victory that Sir William Johnson had obtained in the course of this war. In both he had entirely defeated the enemy, and taken their commanders prisoners. He himself had not the advantages of a regular mil 2 itary education. In his battles, and in what was more difficult, in the art of governing and managing the Indians, he was most of all indebted to superior natural sagacity and courage. In this expedition against Niagara, he had brought forward eleven hundred Indians of the six na-

- Smollet's Hist. England, Vol. '3, p. 418

$$
\text { Vol. I. IF } 3
$$


tions; in the battle he had animated their nat: iral ficrceness and impetuosity; after the sur. iender, he cooled and restrained them within she bounds of order and moderation; in both cases, he knew how to manage the savage tem: per, and to make it subservient to his own viens and purposes. Like other professional men, the British generals did not intend to believe that any thing effectual could be done in their pro. fession, without a regular course of education, discipline, and experience. When Amherst re. ceived intelligence of the death of general Prideaus, he appointed brigadier general Gage to the command, and sent him on from Crom Point to Niagara. Happily for the colonies, Gage did not arrive, till the superior genius and sagacity of Johnson had reduced the fort, and compleated the business of the expedition.

In reviewing the operations of this campaign, it will naturally occur to our minds that the British minister had discovered sound policy, and an excellent judgment, in selecting the genius and characters of the several commander, for the nature of the scrvice which they had to perform. A gencral less couragcous, active, enterprising, and animating, than IVolie, would not have persevered amidst. all the difficulties which attended his situation; nor would have thought of subduing Quebec, when defended by a superior force, under such a commander as Montcalm; nor would have dired to plit the event on the risk of a single battle. Wolfe well knew what, his troops could perform, and the event iumed on in conformity to his expectations and wishes. Johnson foresan hoir the 
Fench and Indians would make their attack, and what would be the consequence of their hurry and precipitation ; and the spirit he discovered in the execution, was equal to the wisdom and precaution of his arrangements. Cool, resolute, and cautious, Amherst left the enemy nothing to expect from surprise, or from what they called a coup du main; but at the same time, he made the Indians feel the horror and vingeance of their farorite system, a war of extermination. When the French officers found that nothing but superior skill or force would be able to withstand him, they prudently declined the combat; and to avoid being made prisoners of war, resigned to him their forts, and the command of lake Champlain.

1760. THE operations of the last campaign had been so extensive and successful, that no object now remained in the northern colonies, but to compleat the conquest of Canada, by the reduction of Montreal. In respect to its numbers, situation and importance, this was the second place in Canada. It was built on an island in the river St. Lawrence, at nearly an equal distarce from Quebec, and the lake Ontario; and was the staple of the Indian trade and resi. dence of the governor general of the colony. "l'sere M. de Vandrieul had fixed his head quarters, and rroposed to make his last stand against the eforts of the British generals. He levied ail the forces that could be raised, collected magazines, erected new fortifications, and avaled himself of all the arts and measures that coul! be adopted by an able and experienced soldier and statesman, His hopes, however, 
could not be derived from the situation or: strength of the city, but upon the natural strength of the country; the woods, mountains, waters, defiles and morasses, that the British generals must have to pass, before they could bring their armies around the city. These, he hoped, might retard the progress of the IEnglish armies, or protract the war till a general peace should be made, or some faromble event cnable the French to afford relief to the colony. That nothing might be wanted to anmate and allure the inhabitants to maire a general and desparate struggle to save the country, he addressed a circular ictter to all the oficers of the militia, in this style:

"Sir,

$$
\text { Montreal, Sune \&, 1760. }
$$

" WIE chevalier de Levy is just returned 'to this town; he has repectited to me the strong: "testimony which he had before given me, of "the gond will, tive zeal, and ardour of your " compriny of nititis.

"Y expected no less from the fidelity of the - brave Cundian, and from their attachment "to their native countr"

"His majesty, who is by tins time, probab' 15 inforned of your brotint victory, will be "no less pleased with this, than affected with "the distresses of the colony ; so that suppo. " sing that peace has not been concivded, on "the receint of this nows, tie ling of Ingland "camet possiuly avoid subscrbin ancin terms " as our monuruh shall kave impos upon him. " You are not uninfomed of the mot al\& vantages which he gained in Erroje chring 
" the last campaign over the Enghish and Prus. sians.

" 'IIE prisoners which are bringing in cvery " noment, all agree in confirming thum.

"J" $\mathrm{F}$ e truth is, his majusty is in person in "Holkand with an army o: $200,000 \mathrm{men}$, the "prince of Conti in Germany witl 100,000, and 'the princes of Doux-Ponts, and Soubise, " command the army of the cmpire of 200,000; 'and lastly, the empress of Russia, and the "queen of Hungary, have joined their whole "force, and were taking measures for the con'quest of the remainder of his Prussian maijes. 'ty's dominions.

- BesIDEs this, the last accounts assure us,

- that the garrisons of forts Frcdcric, Niagara, 'and Chomagan, have sufered greatly by a sick-

"ness, which is not yet sioped, and that the " regular troops in New Englund a $\mathrm{Ne}$ reduced "to nothing:

- Cingral Murray, therefore, has disper'sed manifesioes to no purpose, to magnify his - own nation, to paciry the Canadinns, to engage 6 ther to hay down their arms, to discrecit our - bills of crachnge, and on currencj, at tho "same time that the Engigh tracters ure eager "to procure thom, bocaluse they hare boen re. "guiarly paic!.

" You see, sir, that ine colony is dinwing to - the end of its lardships and diutrenes, and that - it is upora the point of secing rlon'y succeed 6 to scarcity.

- If the inglish matc any atcmut, it can "have no other" object than s'a anbicon of thein "gencrals; we are tworough mepared bo re. 


\section{NATURAL AND CIVIL}

:pulse them with spirit; we have a train of "artillery, besides that which we took from the

" enemy; a still greater proportion of powder,

- ball, and ammunition, for the operations which

'I have projected; we have also provisions

' enough, by means of the resources which we

- shall find in the good will of the Canadians,

- who have the greatest interest in the preserva-

'tion of their religion and liberty. The king's

'troops will even live, if necessary, upon roots,

- when they camot do better, and will not fail

"to join their endeavors to those of the brave

- Canadians.

- My intention then is, that you and all your. - militia, should hold yourselves ready to marcl

- with arms, baggage and eighe days provisions

to our frontiers, when the case shali require ir.

- I believe I may venture to assure you, that "these will be the last dispositions which I shall - have occasion to make for the defence of this "colony; being finmiy convinced, that, some " time in August, at last, we shall have peace,

"provisions, and, in general, whatever we want. I I am, \&xc.

'P. S. You whassemble the miritia of your "company, and read this letter to them. You "will caretinly inspect their arns. If any of - them are out of order you will give them a 'note, and tho king's gun snitli's will repair "them immediately." *

Wrie the marquis de Vaudrieul was thus struggling between despair, hope, and endearor, generil tmherst was concerting and execut-

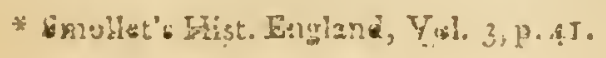




\section{HISTOBY OF VERMONT.}

ing mensures, to bring all the British armics in Anerica, to act in concert against Mintreal. He had sent instructions to general Mura:y, at Quebec, directing him as soon as the season would permit, to advatice up the river St. Lavvrence by water, towards Montreal, with all the troops that could be spared from the garison of Quebec. He appointed colonel Hariland to command 2 body of troops, which were to proceed from Crown Point, through lake Cham. plain, to take possession of the Isle Aux Noix: and from thence they were to advance by the shortest practicable route, to the banks of the xiver St. Lawrence. For himself he proposed to go with the main body of his army by the way of the Mohawk, and Onondago rivers, to lake Ontario ; to embark his troops at Oswego, sail over the lake, and dom the river St. ZuW. rence, to the island of Montreal. By this plan he proposed to bring all his troops against that place, and to inclose and surround the enemy on that isiand.

Tне plan of military operations being settled, the commanders, as early as the season would allow, set themselves to carry into execution the part that was assigned to them. Gent eral Amherst had procured two armed scliooners to cruise on lake Ontario, under the command of cartain Loring; and a great number of batteaux, and other small vessels were provided for the trasportation of the troops, artillery, ammunition, provisions, and baggage. Several regiments were ordered to proceed from Albany to Oswego; and the general himself marched from Scherectarly, with the rest of his troops in 
she latter end of June, aind arrived at Oswego on the ninth of July.

TH $\mathbf{E}$ army being asscmbled, amounted to $\mathrm{a}$. bout ten thousand men; and they were joined by a considerable body of Indians under the direction of Sir IViliam Johnson. Colonel Haldinated, with the light Infantry, the Grena= diers, and one battalion of Highlanders, was de. tached to take jost at the castern part of the lake, and assist the armed vossels in finding a passage to la Gillette. On the tenth of August the whole army embarked on board the batteaux and whale boats, and procceded along the lake torrarcs the aigin of the river St. Lawrence. Understancing there was nothing to fear from the enemy's vessels; the general resolved to proceed down the river to Swegathcie, and ato tack the French foit at Isle Royale; a post which in a great mensure commancied the pas. sage by water, either from or to lake Ontario. On the seventeenth, the row gallies fell in with the French sloops commanded by M. de la Bro. querie; which were forced to surrender, after a warm contest. Amherst now prepared to in. vest the fortress at Isle Royale. Bitteries were raised on the adjacent islands, and the fort was cannonaded also by the armed sloops; in one of those isinds, some scalps were found which the iniabitants had taken from some of the Mohawks, whom they hac slain: The Indians were so inflamed at the sight, that they burned. their chapel, and all their kouses.

Preparations being made for a general assault, the commander, M. Polichant found it most prudont to beat a parley, and surrender on 
capitulation. With the capture of this fort the opposition of the enemy ceased, but the navigation became extremely difficult and dangerous. 'The river abounded with a great number of rapids and falls, which could not be avoided: Great care was taken to guard against the dangers of the passage; but notwithstanding all the vigilance and exertions of the officers and men, the army suffered much in this part of their voyage. Forty six batteaux, seventeen whaleboats, one row-galley, some of their artillery, ammunitjon, and stores, with above eighty men were lost on the passage. This dangerous serrice being effected, the army met with no further difficulty, but ianded on the island of Montreal, Septenicer the sixth, without any opposition from the enemy, except some random shots from some of the flying parties, who instantly disappeared.

WHIE general Amherst had been thus cngaged in preparing for the expedition, and coming down from lake Ontario, general Murray had not been less active at Quebec, and on the river St. Lawrence. During the winter he neglected no metsure that could be taken to preserve Quebec and to subdue the adjacent parts of the country, and many of the inhabitants ac.. tually took the oath of allegiance to the king of Great Britain. The garrison hewever within the walls of Quebec suffered much from the extreme cold of the winter, the want of fresh provisions, and the scurvy; before the end of April, one thousand of the soldiers were dead. and double that number were unfit for service. The chevalier de Levy, on whom the command VOL. $I$ G 3 
of the French troops had devolved by the death of Montculm, was encouraged to hope from the state of the British garrison that Quebec might be reduced by siege before a Britisinfecet could arrive with succours in the spring. For this purpose he collected all the regular troops, $\mathrm{Cd}$ nadians and Indians that he could assemble; and formed an army of more than twelve thousand men. With this force he advanced to lay siege to Quebec in the latter end of Apriil. Murray confiding in the bravery \& discipline of his troops, meant to confound \& rlisperse them by the boldness \& vigor of his measures. On the twenty eighth of April, at half an hour after six in the morning, he threw open the gates of Quebec, and marched out with his little army of three thousand men to give battle to the enemy. A severe conflict took place, and an obstinate battle was kept up for an hour and three quarters. At length the British were overpowered by numbers, and obliger to quit the field with the loss of a thousand men killed or wounded. The French lost a mueh greater number, but remained masters of the field of battle.

MURRAY retreated with his troops within the walls of Quebec; and neither dismayed by the loss of the battle, or discouraged with the weakness of his own situation, made a vigorous defence and determined at every risk and hazard to hold out till suecours should arrive. The eneny did not omit to avail themselves of the advantage of the battle, and the same evening opened their trenches against the place. For several days they camonaded the city with great 
vivacity, but their artillery was not equal to that of the gurrison. On the ninth of Miay a Britis shi: , commanded by captain Desne entered the harbuar of Quebec, and announced the joyfli ners that a British squadron was in the rive:. Ois the fiftenth of Aidy, commodore Swanton arrived, and in the evening anchored above point Levy. Early the next moming two of his vessels sipped their cables to attack the fiect which the French had collected. They were no sooner in motion than the French ships fied in the utmost disorder. One of their frigates was driven on the rocks, another ran on shore and wis burned, and all their other vessels were taken or destrayed. So confounded and dis. pirited were the enemy by this disaster, and the ilead of an approaching fleet, that in the following night they raised the siege of Qucbec, and retreated with great precipitation, leaving their provisions, implements, and artillery. The next morning, Wurray marched out, but found the enemy had fled; and nothing left for him but to take possession of their tents, stores, magazines of provision, ammunition, and artillery.

The affirs of Quebec being settled, and a proper garrison assigned for its protection, Murray prepared to advance up the river to Montreal. The troops were embarlied at Quebec, on board a great number of small vessels; captain Deane in the Diana, undertook the command and the hazard of conducting them up the river. This officer with uncommon abili. ties and attention surmounted all the difficulties and hardships of an unknown, perplexed, and dangerous navigation; and such was his atten- 
tion and vigilance that not a vessel was lost in conducting a numerous fleet, one hundred and eighty miles through an enemy's country, and against a rapid stream, where no English vessel had ever been before. 'General Murray while advancing up the river, every where published manifestoes, inviting the Canadians to submission, and promising them protection under the British government. These prockmations had great effect., Almost all the parishes on the south shore, as far as the river Sorel, made their submissions, and took the oath of neutrality ; one village opposed him with arms, and that by way of example and terror he set on fire. On the north shore, lord Rollo disarmed the inhabitants as far as Trois Rivieres, and took possession of that village without opposition. M. de Levy was all the time watching the motions of general Murray, and waiting for an opportunity to attack him with success; but the tine for such enterprises was past, the people were every where submitting to the British gencal, and were not disposed to venture on hostilities. Thus fortunate and successful in every part of the business, Murray atrived sald with the troops under his command, and landed on the east jairt of the island of Montrcal, the day after Amherst had landed on the west.

'Ine army that was to proceed to Montreal by the way of lake Champlain, was put under the command of colonel Haviland. 'To ficilitate the operaticns of the war, Amherst had directed that a road should be opened from Number Four on Connecticut river, across the Green Mountains to Crown Point. This service was 
performed by a New Hampshire regiment, under the command of colonel Goffe. They began their road at Wentworth's ferry, two miles above the fort at Charlestown; cut down the trees and made bridges, till their road extended twenty six miles. At that place, they found a path, in which they proceeded to Otter Creek ; from whence they found a good road which lead to Crown Point. In this work they made such dispatch, as to join the army at that place on July the thirty first, and brought with them a drove of cattle for tine supply of the army. August the twelfth, Havihnd embarked his troops in batteaux and whaleboats, and sailed down lake Champlain. He met with no opposition from the enemy till he arrired at the Isle Aux Noix. This place had been stroigly fortified, and made some appearance of opposition; some skirmishes took place, and a few were slain on both sides; but the enemy were too weak and too much dispirited to make a formidable opposition. 'The post was soon deserted, and the forts at St. John's and Chambly becane an easy conquest. Meeting with no further opposition, the troops passed on ; and the day after Murray" had efiected his landing, Haviland appeared with his army on the south side of the river St. Lawrence, directly opposite to Montreal. These events and circumstances apjear. ed highly favorable and unerpected. "The three armies pursuing different routes, and unacquain. ted with each other's progress, passed through. a long and dangerous tract in the cnemy's cour... try, and arived at the capital within two days. of each other.

"Belknap's Hist. New Hampshire, Vol, 2, p. 305. 
Notning now remained for $M$. de Vau. drienl, but to make the best terms he could for the colony. Gencral Amherst, on the day in which he arived, formed his army in a plain before Montreal, where his troops lay all night upon their arms ; and swas proccentig to bring on his arillexy, and lay siege to the citr. On the mornirg of the seventh, he received a hiag and letter from Vaudrieul, who sent two officers demanoing a capitulation. Amherst stated the terms which he would grant, and which he signifed that he shoul? not alter. Some letters passed upon the subjoct, but Vaudicul could do no otherwise then to submit to the terms dictated by the British general. "They werc however fitvorable to the Erench colony. The troops sumendered prisoners, and were not to serve against the Linglish or their allies during the war. The whote country of Candata was to be surrendered to the king of Great Brimin; and the inhabitants were to be protected in their estates and religion.

Ty us was complented the corquest of Canada, september the eighth, 1760, in the sixth year of the war, and alter the most severe sirnygles. During the contest, six battles had here fought, the fortune of which was equaly divided. 'The first of these wat at the meators, zenr fort Du Quesne, in which Braddock was slain, and the Frunclz zuccessful. The rexî was at lake Creorge, where Diskau was defeated and captured, and Johnson graned the victory. The third was at "foconderog", in which is bercrombic was defeated, and Montcalm gained the advantage. In the fourth, at Niagara, tho 


\section{HISTORY OF VERMONT. 451}

French were subdued, and Johnson gained a compleat victory and conquest. In the filth, at Quebec, Wolfe and Montcaim the greatest generals that had appeared in America, both foll ; but victory and conquest were on the side of the British. The sixth was at Sillery, Murray was defeated, and M. de Levy gained the battle. The British nation and colonies for more than seventy years, had been aiming to accomplish the business, but without success. A large country was now added to the British dominions, and an end put to the depredations and ravages of the Indian tribes. The grand contest for which the war was begun, appeared to be decided; and the future prospects of the colonies bore the aspect of tranquility, prosperity, rapid increase, and improvement. All these hopes and prospects seemed to be confirmed and compleated by the treaty of peace signed at Paris, February the tenth, 1763. By this treaty, the ling of 'France ceded and granted to the British king in full right, the whole country of Canada, with all its dependencies, in the most ample manner and form. All that the British colonies could wish respecting Canada, was now obtained; and the time was come, in which it might reasonably be expected, that all their fucure exertions would be employed for the im. provement and prosperity of their country. 
IN reviewing this system. of colonial waty not only its military operations, but its origin; moral and political tendency and effect, are also worthy our attention and remark.

THE ORIGIN of these wars will easily be found in the different interesis, feelingrs, and passions of men. The Europeans who made the first settlements in America, were from dif: ferent parts of the European continent; from Spain, Portugal, England, France, Holland and Sweden. They brought with them the opinions, customs and habits, of the governments and churches to which they had been accustomed, ant were more or less infucnced by particu: lar moral considcrations, and local circumstances. These riere greatly difienent; but in one view and design, they were all agreed. They all meant to obtain possession of the different parts of the American continent, to which they removed; and to make a firm and permanent settlement on the lands, of which they took possession. The Indians, unacquainted with the European character, and too ignorant and credulous to suspect unfriendly or mischievous designs in their new visitors, every where received them with the tokens of unfeigned hospitality and joy; and rieved them as a race of beings; far superior to themselves. The Europeans availed themselves of their superior knowledge in all the arts, commeres and brisiness of life; and of the native sinplicity and imnorance of the original inhabitants. By a careful attention to the Indian temper, character, and state, they engaged their confidence, procured their friendsibip and obtained their consent to settle on 
their lands. It was not till after a period of years had taken place, that the natives discerned the policy, and became jealous of the increasing power and numbers of the European settlers. With this jealousy the savage temper became sullen, gloomy, suspicious and resentful. Controversies took place, mutual provocations, com* plaints and injuries succeeded ; and the Europeans were every year advancing, and forming new settlements in the Indian country. Disputes about property and encroachment ensued; and these had the same effect in the colonies that they have in every other part of the globe, they gradually but novoidably resolved themselves into an appeal to force; and when once hostilities and slaughter began, war would assume all the barbarity and cruelty that was inseparable from the Indian passions, customs and habits. The result was every where the same; sooner or later war broke out between the Indians and the Europeans who were setting and taking possession of their country.

In addition to the wars that arose from this. calise, there was another equally certain and unavoidable, the seat of which lay in Europe. The different interests, the mutual hatred, the perpetual pride and ambition of the Iiuropean. monarchs, kept their kingdoms in cunstant contention and war ; and these wars, by the decrees of their sovereigns, always followed thcir subjects into the new world, and became one of their heaviest calamities and curses. Whenever the kings of England or France supposed it would be for their interest to involve their kingdoms in blood and slaughter, their colonics in

$$
\text { vol. I H } 3
$$


every part of the world were required to join in the folly and madness of their sovereigns ; and to plunge themselves into all the calamities and miseries of their bloody contests. In both these causes there were perpetual sources of war in the colonies; and there was no rational ground to expect that they could be avoided, while the colonics were extending their settlements into the Indian country; or while they remained connected with the Europear sovereigns or powers.

AmoNG the dangerous consequences of these wars, the MORAL EFFECT was greatly unfavorable, and corrupting to the human mind: They operated with a certain and cunstant tendency to destroy the moral virtues of humanity, candor, and benevolence ; and to produce the spir. it of bigotry, intolerance, revenge and mutual hatred. It was not possible for the men that were constantly endeavouring to injure and destroy, to love and do good to one another ; instead of this, they were constantly learning to hate and to abhor each other. The spirit of intolerance and bigotry seems to be unavoidably connected with ignorance, and to be incurable by any thing but science and philosophy. This raving, fiery spirit of the partisans, derived new force and inflammation from the perpetual wars in which the colonies were engaged. The peo. ple in the French colonies were trained up to believe that they belonged to a monarch and to a church, which were absolutely iniallibie; the different sects and parties in the English colonies did as firmiy beileve, that they them. selves were never in the wrong. Io carry 
their political and theological prejudices and hatred to the highest degree, nothing was wanted. but the cruelties and barbarities of an Indian war. Both parties very justly reproached each other, for the inhumanity and wickedness of thcir proceedings; and they well knew that the Indians in one part of the country, were under the management of the French ; and in another, under the direction of the English. Policy and disguise would of course avail themselves of all the help and assistance that could be derived from the pretence or abuse of religion, to represent the opposite party as faithless, corrupt, heretical, opposers of God, and all that was good.

To carry this scene of mutual hatred, bigotry and abuse, to its greatest height and extent, time and experience had shown that the surest way was to put it under the management of a set of intolerant pricsts, genus irritabile vatum, and to them, the politicl leaders looked to afford a powerful assistance, by representing their enemies, under an odious and awful character. In these exploits the English and the French seem to have been very successful in destroying the spirit of candor, charity, and benevolence; and in promoting that of mutual aversion, extreme bigotry, and intolerant hatred.

WHILE the moral tendency was thus unfortunate and corrupting, the effect of continued war on the literary and scientific character and pursuits of the colonics, was equally unfavora. . ble and degrading. It was the peculiar felicity of the first settlers of the English colonies that the were descended from the most enlightened 
part of Europe, and at a time when considera ble advances had been made in the arts and sciences. The clergy, and several of the leading men that came over with the English, when they made their first settlements, had been educated at the universities of Cambridge or $\mathrm{Ox}$. ford. They were well acquainted with clitssical literature, had been instructed in the philosophy of that day, and were eminent for their knowledge in the theological debates and controversies that agitated the English nation at that time. Disgusted with the English hierarchy, and viewing with horror the arbitrary pro. ceedings of Charles the first, and his archbishop Laud, they removed into America', to be out of the reach of prelatical power and perse. cution. Without a preconcerted plan of eccle. siastical power or policy, they adopted such a. method of ecclesiastical proceedings, as utility, time, and circumstances suggested. Happily for themselves and for their posterity, nature and christianity led them to adopt one, that was equally favorable to the interests of morality and religion; and to the rights and liber.. ties of mankind.

Juste $Y$ pleased with the form, in which the christian church appeared in the new world, and apprehensive of the important consequen. ces it might have on sciciety, they wished to give to the church and to the country, all the advantages that might be derived from the infivence of the arts and sciences. So early as the ycai 1658, they began the foundation of a College at Cambricige; and were warmly en. gaged in maing provision to educate their youth 
in useful knowledge and to supply their chur. ches with well educated and learned ministers. In 1700, the colony of Connecticut followed the example of Massachusetts, and founded a sem. inary now called Yale College. Both these so. cieties received much assistance from the civil government, and were warmiy supported and encouraged by the clergy. And it was from them, that almost all the acquaintance which the country had with the arts and sciences, was derived. To increase the influence and importance of these colleges, and to preserve a deco. rum and uniformity in their churches, their ministers wisely established a rule to discourage the application of those to the ministry, who had not received an education at their own or at some other College.

THUS educated in the best manner the state of the country would admit, the order of clergy appeared to advantage in the colonies. A. mong the doctrines which had divided the chris. tian world, they had almost universally embra. ced the opinions of Calvin ; but were not deficient in inculcating the duties of morality, and the maxims of practical virtue. In respect to their learning, piety, gravity, and regularity of conduct, this order of men were highly esteemed by their country; and several of them were cminent as writers, and popular preacliers, With more strength and originality of genius than any former metaphysician, EDwARDS had gone further than any other man, to give deci. sion and certainty to metaphysical theory and reasoning. In trating on the ancient contro. zersies respecting futc and freewill, wone of the 
metaphysical writers had discovered so much ingenuity and acumen. But like all the rest, while labouring to establish the doctrine of fate, necessity, and liberty, he clearly proved that neither the calvinistic, nor the arminian theory, nor the metaphysical way of reasoning, ever could cx. plain or clear up the subject; and that the connecting truths or principles, which would serve to show the consistency between the unaltera. bie councils and decrees of heaven, and the frce agency and accountability of men, were not to be found in any of the metaphysical systems, that had yet been announced to the world; and that no such theory or system ever could explain, or be applied to the powers or actions of animals.

Others of the clergy had wrote to great advantage in the controversies with the church of England, and on the doctrines and claims of the church of Rome. But the country had not yet been agitated by any controrersies respect. Ing the trinity, the incarnation, the atonement, the necèssity, evidence or reality of miracles, prophecy, or revelation, and perhaps no order of clergy ever were more useful to mankind, than those who had directed the religious affairs of the colonies at this period.

In the courts of law, the business was as well done, and justice was as impartially administered, as in any part of Europe. The common law of England was the rule of proceeding, and happily for the country, neither the provincial movernments, the judges, or the lawyers had at. tempted to alter or to improve it. What rela. ked to the local circumstances of the colonies 
was regulated by provincial laws; and these the colonies were much better qualified to determine, than any European kings or parliaments. The ludicrous absurdities which the system of monarchy had introduced into the English sta. tutes, did not apply to the practical course of events or of business in the colonies; and their courts had no occasion to compute on the corruption of blood, the respectability of an infamous nobleman, or the sacredness of royal vice or folly. Most of their lawyers were men of a liberal education; and several of them were among the most respectable and useful men in the country. But the time was not come to attempt to improve the law or the profession. No books of reports, no treatises on law or evidence, or any thing appropriate to a colonial system of law or practice had appeared; all was in subjection to British precedents and to British im. portance.

THE medical part of science and the branches more immediately connected with it, had as yet only bore a practical aspect. The physicians were as. useful and practised with as much success in the colonies, as in any part of the globe, and no where did the people enjoy more health; but their knowledge and success was much more the result of observation and practice, than of theory or system. No medical schools or professorships, no regular courses of surgery, chemistry, or clinical instruction, had at that time been instituted in the colonies; and scarcely any thing had been done in the materia medica, in botany or in the collections of natural history. One important discovery was iutrodu. 
ced in the colonies as early as it was in Great Britain. Dr. Cotton Mather, of Boston, had observed in the philosophical transactions, an account of the manner in which inoculation for the small pox was practised in the Turkish dominions. At his recommendation, Dr. Boylston, one of the physicians at Boston, introduced it at that place, in the year 1721 . It met with success ; and with the opposition, which is always to be expected, when a new method of practice is introduced. But although it cxposed the first promoters of it to a considerable share of professional and popular resentment, it was eventually attended with much success, and almost universally adopted.

THERE was an accuracy and a minuteness in the historical productions of the country, which marked the feelings, pursuits and views of the colonies with much precision ; but the transactions of which they treated, appeared too local and too small, to engage the attention of the world. Hubbard wrote a very accurate and useful history of the Indian Wars in New England. Moretun wrote a Memorial, which was of use to preserve the memory of the first settlers and their proceedings. But the most that was done this way, was by $D r$. Cotton Mather, of Boston. With a singular genius, with much of the Hebrew literature, and a warm imagination, in a book to which he gave the title of Magnalia Christi Americana, he wrote minute and lengthy accounts of all the ecclesiastical, historicil and literary proceedings of the country till the year 1692. Penhallow, at Portsmouth, gave an account of the Indian Wars; and Dour- 
Kass, at Boston, wrote a historical and political summary of the affairs of the colonies 'to the year 1750. In Virginia, Stith and Beverly pub. lished histories of that colony to the year 1700 . In New York, Colden wrote the history of the five, nations of Indians, in 1747; and in 1756, Smith published a history of the province to the year 1732. In these productions there were authentic and useful records of the early pro: ceedings of some of the colonies. They were viewed in Europe as too small matters to engage the public attention; and it was not suspected by her historians, that the American, writers were describing principles and proceedings, from whence the greatest of all human empires was destined to arise.

SPeculative science was not much wanted. and had not been much cultivated in the coun. try. In mathematics no attempts had been made to cultivate the higher branches; what was necessary and applicable to the affairs and business of life, was generally, and well understood. In natural philosophy the prospect and attention was more engaging. In the beginning of the eighteenth century, Keil had introduced in Engiand, the experimental method of teaching this science. Desaguliers had greatly im. proved the plan, and taught it systematically in a regular course of experimental lectures. Isaac Greenwood, a young gentleman of Boston, edu. cated at Harvard College, had been in London, attended Desagulier's lectures, and had beeir his assistant in the business. Mr. Hollis, of London, in the year 1726, established a professorship of mathematics and natural philosophy in Harvard

vox. 3 I 3 
Collegie, purchased an apparatus and sent Green: wood as his professor to Cambridge. Greer. wood of course introduced the business at Harvard College, in the advanced state the science had assumed at London. A taste for this science being thus introduced, it became the favorite study of the young gentlemen who were under a course of education; but as no individual had any philosophical instruments, it was seldom pursued any further than a course of academical education had carried it. In astronomy the attention had been carried a little higher. In 1694, Brattle began to make some astronomical observations at Cambridge. Robie pursued the same business, and Winthrop was attentive and accurate in observing the celestial phenomeria. Godfrey, at Philadelphia, by the strength of an untaught genius, discorered the sextant, which now bears the name of Hadley. The observations and the names of these gentlemen, appear to advantage in the transactions of the Royal Society of London.

Is natural history some useful observations and accounts had been published relative to the weather, climate, vegetables and animals, in Carolina, Virg̈inia, Pennsylvania, New York and Massachusetts; some of them were by na. tives of the colonies, but the most by persons who came from Europe to reside in the country. Clissical knowledge was taught with reputation and success in the Colleges, and by the grammar schools. All the men of education Inad been instructed and were acquainted with the works of some of the most eminent orators and poets of antiquity. Colleges had becrs 
founded at Cambridge, New Haven, IVilliamsburg, Princeton, Philadelphia and New York. But the genius of the country had not been employed in attempting any considerable productions in poetry, oratory, or the fine arts. In one article however, the New England colonies exceeded the customs and attainments of Europe: In every considerable town they had a grammar school, and all the children were taught to read, write, and go through the common rules of arithmetic; and nothing was more uncommon or disreputable, than to be unacquainted with these arts. This was the knowledge the colonies most of all needed, and this they had made universal ; much further they could scarcely expect to go, while destruction was every where around them. War, French and Indian war and ravages, engaged the attention of the whole country; exhausted her finances, and required her constant attention and exertion. And while this was the case, neither the resources, the attention, or the genius of the country, could be much applied to the pursuit or cultivation of science. The men who sat down to contemplate such matters, would have their attention forced to other subjects; they must fly, or like Archimedes be slain over their problems; and in almost every process they: might say of their country.........multo spumantem sanguine cerno.

ThE same cause that thus proved unfriendly to morals and science, was also greatly injurious to the population of the combtry. In the English colonies it was found from the registers of life and death which had been kept in some 


\section{\$64 NATURAL AND CIVIL}

of their oldest towns, that the number of years in which the inhabitants by their natural increase would double their numbers, did not ainount to more than twenty four, 'or at most twenty five years. Such observations lead to the most flattering calculations, respecting the future popu. lation and number of the people; but in most of the colonies, these calculations entirely failed. In none of the provinces were the people more industrious, sober, or agricultural, than in Mas. sachusetts and New Hampshire.' In the year 1713, it was found that there was not double the number of people in Massachusetts to what there was in 1675. The same was found to be the case in 1762; at that time the number of inhabitants had not doubled from the year 1722.* The same observation applied with still greater force to New Hampshire. 'The cause could not be found in emigration; nor did it arise from any uncommon mortality or sickness. Nothing of this nature had taken place in either of those provinces, except the losses occasioned among the children by the disorder called the throat distemper, in 1735 and 1736 ; and this was local, and of a short duration. The cause was in the constant state of war, in which those provinces were involved. From 1675, when the Indian war under Philip first began, to 1713 , five or six thousand of the youth of the country perished by the enemy, or by sickness contracted in the sèrvice. From that time to the conquest of Canada, there were constant calls upon the young men to engage either in 'offen." sive or defensive service. The numbers that

- Hutcbinson'o Hist. Massacbrsetts Yol. 2, p. 183. 
perished in these services were unavoidably great. If we may judge from the course of things in the colonies, nine out of ten of these young men would have been fathers of families. Cut off and wasted away by an incessant scene of war, the population of the whole country was checked and prevented.' At the end of fifty years, for every young man slain in the wars the loss occasioned to the country was nearly four inhabitants ; so many more would probably have been found in the country at the end of that period: had the colonies remained in a state of peace and tranquility.

$O_{N}$ the agriculture, the settlement and cultivation of the country, the effect of war was still more pernicious. The most important of all pursuits to the colonies, was the settlement of their country. On this depended their defence, their strength and their existence. In the most peaceable and quiet times, this was a matter of much difficulty', hardship, labor and suffering. To collect together a company qualified and disposed for such "enterprise; to quit the ease and enjoyments of domestic peace and abun: dance ; to carry their families through the woods, mountains, rivers and swamps, where there wis no road or track; to construct huts of $\operatorname{logs}$ and the bark of trees; to cut down the woods and open' the lands to the influence of the sun and the air ; to fence, sow, reap and gather their crops; this was the beginning of the sccne, and a series of difficulties which must in some nueas" ure be gone through the first year of their re: moval. They had then to watch and guard the it eatle and their crops against the ravages of aic 
bears, wolves and other ferocious animals, with which the country every where abounded; and at the same time to raise their provisions and make their raiment. In the best possible state of things this was a seene of hard living, of hard labor and great suffering; and it was not in a less period than five or six years, that the new settlers could procure the necessaries of life in such quantities as to be comfortable; or in any considerable degree to be free from the danger and suffering of hunger and nakedness.

Acarnst these difficulties however, they truggled with success, and in a few years found their circumstances more comfortable and encouraging. But when a war broke out, their dangers and their sufferings often scemed to be without measure, and without end. An attack was suddenly made upon one of their settlements, when the inhabitants were unprepared for defence, and without suspicion of danger. The first notice of the approach of an enemy, would be about break of day ; the Indians would assault every house at the same time, slay such of the inhabitants as made any resistance, lead the others away prisoners, burn the houses and buildings, and slaughter all their cattie. In this way, several of the plantations were destroyed, rebuilt, destroyed again and then resettled. "These rere scenes to which every part of the frontiers werc cxposed, at the kreaking out of every war. The effect was, the most advanced settlements were broken up crery war; the inhabitants returned to the old towis, and all thit. their labor and sufierings had procured for many years, was often swept away in one day. It was 
impossible that the settlement of the country should proceed with its natural progress, in such a state of things. And hence the colonies were obliged to adopt a debilitating caution, reserve, and slowness, in making their advances, and extending their settlements into the country.

In the year 1752, a proposal was made to efo fect a settlement on the rich lands at Coos, on Connecticut river. It was proposed to lay out one township on the east side, and another on the west, at the place now called Newbury, in Vermont. The governors of Massachusetts and New Hampshire approved of the proceed. ings, and a large number of persons engaged in the enterprise. A party of men were sent up the river in the spring, to view the lands, and lyy out the proposed townships. Some of the Indians of the St. Francois tribe observed their motions, suspected their design, and forbade their proceedings; at the same time they sent a messige to the commander of the fort at Num. ber Four, informing him that they would not suffer the English to settle at Coos. The Indian mandate was comminicated to the governurs of the two English provinces, and such was tireir fear of the Inciuns, that they meekly and quietly laid aside the whole business. To such mortifying disgrace and caution, was the agriculture, the settement and the cultivation of the country, constantly subject. And yet on these, the sality, the wealth, strength, population, and commerce of the whole country depended. Of ail wijects this was the most important, to the colonies; and the men, who in that state of things scttled a new town, did more important 
services to their country and to mankind, than those who amused all Europe with an astronomi. cal observation, a physical experiment, solved a new problem, or wrote an elegant poem, or 2 celcbrated volume of history or philosophy.

THE political effects of the wars were also greatly dangerous, and injurious to the colonies : they kept them in an almost absolute dependence on the European powers and monarchs. It was not with an expectation of deriving any assistance from their European sovereigns, that the first settlers came into the eastern parts of America ; it was to get rid of their ecclesiastical authority and intolerance, that they left their na: tive country: When they arrived here, it was in consequence of a patent from James the first: and they understood their charter as a sacred compact, describing the grants that were made to them by their sovereign; and the nature of the allegiance that they were to bear to him. Their ideas of cisil subjection were that birth was not a necessary or an unalicnable cause of submission, to any civil government; but that when they left their native country, all the obli. gation they were under to the king of England, arose from voluntary compact ; from their own agreement and act in accepting their patent, and by that entering into a voluntary contract of submission and obedience to the king of Eng.. land. They had no doubt but that the country to which they came, in respect to its soil, dominion, lordship and sovereignty, belong: do the Indians, and not at all to the European monarchs; and that when they had fairly purchased these of the rightful owners, they had a right to 


\section{HISTORY OF VERMONT. 469}

set up what forms of governments they pleased; consistent with their patent and charter, by which they had engaged their future allegiance to the king of Eingland.* Whether these prin ciples were, or were not in conformity to the principles of the English laws or monarchy; they were certainly founded on the law of nature; and were therefore of an earlier origin, and of a more sacred authority than any English law ever could be, which considers birth not only as a local, bat as a perpetual and unaliena. ble cause of civil subjection.

$I_{N}$ opposition to every sentiment of this kind, the English kings believed that every child born in their dominions, or derived from any of their subjects, belonged to them ; and that his very birth implied an obligation to constant, perpetuall and unalicnable allegiance. In conformity to their principles, they soon discovered that they meant to regard or disannul their patents as they pleased ; to alter or set aside their charters ; to frame, destroy, or alter the colonial governments as they chose ; and with the concurrence of their parliaments, "to bind them in all cases whatsoever." It is not possible to form any idea of the most absolute, despotic, tyrannical power, that ean carry its claims beyond this.

TH E colonies, though holding very different political principles, were not in a state to contend with their sovereigins. Surrounded with enemies and involved in wars, both the English and French colonies looked to their kings for assistance; and while the one met with this Find of help, it bccame necessary for the other

* Hutchirsori's Hist. Massachusetis, Vol, I, p.2.3.

vio I, I; $\mathrm{K} 3$ 


\section{NATURAL AND CIVIL}

to seek the same kind of assistance. A depen. dence on and subjection to the European powers and monarchs of course took place, which excluded every idea, and every desire of independence; and the colonies viewed their relation and connection with the European governments from which they descended, as a matter of necessity, safety, and the highest honor. The British kings and ministers believed that the science of government contained such profound and sacred mysteries, that the people could neither understand nor manage them: the people in the colonies were in such a state of political impotency and submission, that they were in fact looking to the European kings and ministers, frequently unacquainted with any part of the business, to manage and direct their govern. ments. This dependence of the colonics on the European kings was attended with many, and with great disadvantages. It embarrassed and perplexed their own 'governments, encouraged the ambitious and intriguing to be perpetually complaining and meddling, restrained their trade and commerce, prevented the most necessary and useful manufactures, subjected them to injurious restraints, confined their business and pursuits within narrow linits; and was calculated to keep their minds in a state of perpetual infancy, inactivity and weakness. And it was not their own desires and inclinations, but the folly and oppressive policy of the British ministo and king, that taught them to study their rig." and to understand the danger of submision to heir livopean masters.

Such as the colonial system of war. Hav. 
ing both an American and an European origin, it was not to be expected but that from the one or the other of these sources, it would be almost perpetual ; and while it continued the evils that were connected with its moral, literary, physical, agricultural and political effects, could not be avoided. In Europe, when their monarchs were engaged in such contests, which ever party gained an increase of territory, all the sovereigns obtained an increase of wealth, of power, of dependents, of infuence and authority. It was evidently their advantage to have war as frequent and constant, as the firances and circumstances of their kingdoms would admit. In the colonies all was the reverse. The system of war served here to inflame and imbitter the minds of men, to keep them unacquainted with the arts and sciences, to retard the population, and prerent the settlement of the country; and to kecp the colonies in a hurtful and disgrace. ful dependence on and subjection to European kings and nations. And it was not till they rejected this degrading submission and dependence, that they arose to their proper rank and station among the nations and powers of the world. 
$-$

3

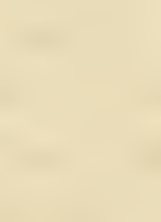

sa

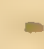

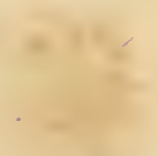




\section{APPENDIX.}

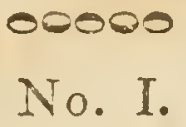

\section{An Account of the Variation of the Magnetic Netdle, in the Eaftern States. CHAP. I. p. 22.}

IN laying our lands in America, the direction of the lines, is generally taken by the Magnetic Needle. The inltruments which have been generally ufed, are the Plain Table. or the Circuinferentor, divided into degrees, and fitted with a Maguetic Ncedie of three or four inches radius. Had the greateft poftible care been aken by able mathematiciars, it would not have been polfible tor them, whill luch iull ruments, to have avoided many errors and mistakes. But in tcascely any inflance has the variation of the necòle been known, or at all olicnded to. Many, and almolt eridlefs controverfies and lawfuits, have arilen from this caule. It many inftarces no data couid be found, by which it was folible to come to a jult decifion ; the variation of the Mognetic Needle. at che rimes when the contefed lines were run, being unknown. Oufuch accourts, the knowiedge of the Maznetic variations in the unland parts of 4 merica, is become a matter of great importance to the people; their interen and property in many cafes, being much affe $\varepsilon$ ted by it.

Frrm the year 1302 , the dircetive power of the Magnet has been empioyed with gieat fuccels, in the affairs of navigation. Butche firft account that we have of any oblerved variation in its ditedion, was by Columbus, in the year 1492 , in his firf royage 10 Amesica. Until that time, philofophers unitormly believed that the pole of the Magnet, exally coincided with the pole of the earth; and thcy had no idea of any fuch thing, as a variation. Amidn the uncommon lcenes of difficulty which oppoled the views, and exercifed the genius of the difcoverer of Amcrica, when he had advanced two hundred leagues welt of the Canary Inands, his compa's began to fail him; and it $u$ as found not to point to the pole of the earth, or exactly north. but one degree to the welt of that point. From that time the variat:on began to be ob erved, and became more and more knnwn. For the laft century and a half, mathematicians lave made it a regular part of their bufinels co obferve it, in different parts of the earth; with the annual alterations that are conftantly taking place.

In the year 1723 , a very accurate obferver, G. Graham, of London, difcovered that the nagnetic necdle had a diurnal, as well as an annual variation. And it is now well known to philorophers, that from about eight o'clock in the morning, the Magnetic Needle verges to the WeAt, uratil about two o'clock in the afternoon. When it has attained its greateft wefward variation, it gradually returns to the eaft, until about eight or nine o'clock in the evening; when it becomes ftationary, until the next morning. Tables expreffive of this diurnal variation are become common; and are to be found in the tranfactions of all philofophical focieties. Thus in the moft regular fate of the Magnetic Needle, it is confanily fubjeft to two variacions; an annual and a diurnal one.

The effect of thefe variations are at all times fuch, that the Magnatic Needle can never give to the furveyor who follows its disections, a firaight or an accurate line. And it ought not to be ufed at all, where the bufinels requircs great accuracy and precifion. It is however farcely practicable in America, to fubllitutc any thing better in the room of it: Moft of the lines which have been a!ready run by furveyors, were run by the Needle ; this 
is much the mof convenient infrument that can be earricd, or wed in the wonds; the cxpence of running lines any other way, would be too great for individuals to bear; and the furveyors are not qualified on run them by the true meridian. For fuch reafons it is probable itidi the Niagnetic Needle will fill contiruse to be the inftrument, by which the lires will be run, and the cownthips be laid ant in America. We mult therefore endeavor to provide the be? remedy we can, for an ersor or evil, which we cannot eafily remove. The ben remedy which the cafe admis of, is an accurate ob etvation of the variation of the Magnetic Need!e, at the time wher divifional lires are sun. "This thould be done bi able mathematicians, aurl in as inany places in flate, as may bc. Such obfervations will afford the beft direction, turveyors will be able to find, to cnable them to determinc what is the real or true direction of their Magnetic lines. - It is with tlis view, that the follos ing Table is fubjoiner.

Magnetic Obsertations made in Canada, and the Eastern States of America.

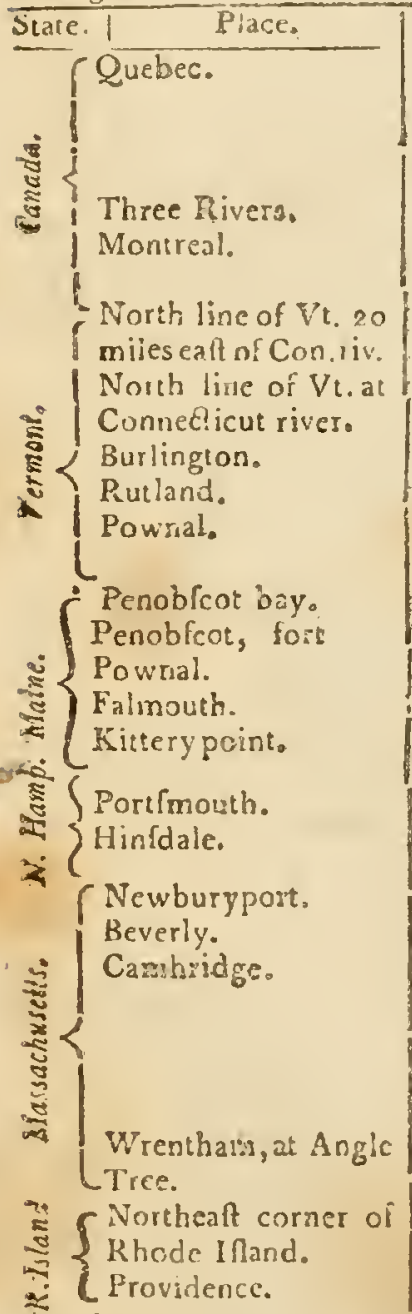

\begin{tabular}{|c|c|c|c|}
\hline \multicolumn{2}{|c|}{ Iime. } & \multicolumn{2}{|c|}{ Variarion } \\
\hline \multirow{4}{*}{ actober } & 1649 & $16^{\circ}$ & $\mathrm{o}^{\prime} \mathrm{W}^{\prime}$ \\
\hline & 3686 & 15 & $3^{\circ}$ \\
\hline & 1785 & 12 & $3^{\circ}$ \\
\hline & 1793 & 12 & 5 \\
\hline \multirow{4}{*}{ Augun } & 3785 & 9 & 30 \\
\hline & $\begin{array}{l}1749 \\
1-85\end{array}$ & 10 & 38 \\
\hline & & & \\
\hline & 1785 & \multicolumn{2}{|c|}{7,40} \\
\hline \multirow{4}{*}{\multicolumn{2}{|c|}{$\begin{array}{l}\text { Nay } 13,1806 \\
\text { Warch } 3.1793 \\
\text { April } 17.1789 \\
\text { Sept. 30, } 1786\end{array}$}} & 9 & \\
\hline & & 7 & 38 \\
\hline & & 7 & 3 \\
\hline & & 5 & 52 \\
\hline \multicolumn{2}{|c|}{ June 15,1605} & 11 & 35 \\
\hline \multirow{3}{*}{\multicolumn{2}{|c|}{$\begin{array}{r}\text { July } 18, \quad 1761 \\
1763 \\
1771\end{array}$}} & 8 & 0 \\
\hline & & 7 & 45 \\
\hline & & $i$ & $4^{0}$ \\
\hline & 3771 & 7 & $4^{8}$ \\
\hline & 2772 & 6 & ro \\
\hline \multirow{2}{*}{\multicolumn{2}{|c|}{$\begin{array}{l}\text { Augunt } 6,1781 \\
\text { Auguft } 2,1,81\end{array}$}} & 7 & 18 \\
\hline & & 7 & 2 \\
\hline \multicolumn{2}{|c|}{$\begin{array}{r}\text { Augult } 2,1781 \\
1742\end{array}$} & 8 & 0 \\
\hline \multirow{2}{*}{\multicolumn{2}{|c|}{$\begin{array}{r}1 \% 57 \\
1753\end{array}$}} & 7 & 20 \\
\hline & & 7 & O \\
\hline \multirow{2}{*}{\multicolumn{2}{|c|}{$\begin{array}{l}\text { June } 20,3782 \\
\text { June } 1,: 788\end{array}$}} & 6 & $4^{6}$ \\
\hline & $=788$ & 6 & $3^{8}$ \\
\hline \multicolumn{2}{|c|}{ April 7, 1785} & 5 & $\therefore 9$ \\
\hline \multicolumn{2}{|c|}{$\begin{array}{ll} & 174: \\
\text { June } & 1769\end{array}$} & 7 & 30 \\
\hline \multicolumn{2}{|c|}{ Sepr. $18,1780^{\circ}$} & 5 & 25 \\
\hline \multicolumn{2}{|c|}{ Sept, 25, 1786} & $\begin{array}{l}5 \\
8\end{array}$ & $\begin{array}{r}3 \\
45\end{array}$ \\
\hline \multirow{2}{*}{\multicolumn{2}{|c|}{ Sept. 28,1750}} & 7 & 2.0 \\
\hline & & & \\
\hline
\end{tabular}

Observer.
Des, Hayes.
$\left\{\begin{array}{l}\text { Holland, Sur. } \\ \text { veyol Gemeral } \\ \text { of Catiada. }\end{array}\right.$
M. Gillon.
Holiand.
Whitlaw, S. G.
Dr. Williams.
$\{$ Dr. Williams

Weymouih. S. Winthroz Hollard. Holland. Wright. Dr. Williams. Dr. Wiliard. $\{$ Dr.Winthrop \} Dr. Williams.

Dr. Williams. Cros. f. r. : i, b.R. I. \& $\mathrm{Mar}$, Dr. West. Dr. Wslliznzs. Dr. Willia oss. Wells, S. G. Gov. Burno: . dlexanster, 


\section{No. II.}

\section{Observations on the change of Climate in Europe and other places. CHAP. IV. p. 80.}

THE change of climate which has taken place in North America, has been a matter of conftant obfervation and experience. Is feems to be the univerfal opinion of hiltorians and philofophers, that there has been a more remarkable change of climate throughout all Europe. There are feveral phenomena from which it may be thown with much certainty, that thi: has been the cafe in feveral places.

In the land of Paleftine, about the latitude of 30 or $3^{I}$ degrees, north, the author of the book of Job makes ufe of fuch language as this, "Haf thou entered into the treafures of the fnow? Or haft thou feen the trealures of the hail ? - Out of whore womb came the ice P-Aud the hoary froft of heaven, who hath geridered it ? - The waters are hid as with a fone, and the face of the deep is frozen." Job xxxviii. 22, 29, 3 . Thefe are probably the words of Mofes ; and they are expreflive of that degrec of cold, in which the furface of water is fo trongly frozen as to conceal its fluidity, and refemblc the confiftence and bardnefs of tlone The degree of heat in which this effet takes place in rivers, ponds and large collections o! water; 1 have generally found to be about 25 degrecs of Farenbei:'s thermnmeter: suith a duration of a week or ten days. We thall not therefore be far from the trush, if we conclude that the extremicy of the cold in the land of Midian, could not have been lef's than 25 degrees, in the days of Mofe's : And. that fuch a cold, was of fome days duratinn. Such was the degree, and the effect of the cold in the land of the Midianites, about $32 \frac{1}{2}$ centuries ago.

In the writings of David we have alfo a defcription, of what was eltecmed a fevere feafon. "He giveth fnow like wool: He fcastereth the hoar froft like athes. Hecafleth forth his ice like morfels: Who can $\mathrm{At}$ and before his cold ?" P[alm cxlvii. 16, 17. This account mult have been writsen at leaft $28 \frac{1}{2}$ centuries ago. The language of the poet docs very flrongly exprefs the effeet, which the cold had on the feelings of men in that warm elimate. But the account which he gives of the appearance and form of the ice, denotes a leis degrec of cold than what took place in the days of Mofes. When the degree of lieat is but 31 degrees of Farenheit's thermometer, the ice may appear to becalt into the form of morfels and cryltals : And this fcemis to have been the greateft degree of confifence, extent and lardnels, in which the poet had either feen it, or conceived of "it. It Mould feem thercfore that from the time of Mofes to David, the cold had abated in the land of Paleftine: That four centuries before, it hid the wain iers as witl a flcre, and caufed the face of the deep to be frozen: But that nnw it only caft out the ice like morfels or cryttals. The difference in the degree of cold necelfary to produce thefe effeEts, is abcut 6 degrees.

We have here an accourst of the climate in the land of Paleftine, fo far back as 28 and 32 centuries. Inftead of treafures of fnow, hail, and ice, $a$ frozen drep, and cold which can fcarce be ftood hefore, the inhabitants of that couniry now find a but, fultry climate; in which fnow and ice are never feen. We have not an account of any meteorological obfervations made ai the places, where infes and David lived. The climate is probably much the fame at thofe places, as it is in others of a fimilar latitude and fisuation. We may therefore make ufe of thofe which have been made at Grand Cairo, as the moft appiicable, and the beft which we can find, to rive us an idea of the temperature of the winter in thofe parts of the globe; Crand Cairo lies iv the lativude of $30^{\circ}$ north. Accordiog to Mr. Niebur's 
obfervations made there in the years 1761 and 1762 , the mean heat of chofe ycars uas $73^{\circ}, 65$. The mean heat in the month of January was $57^{\circ}$; that of February was $63^{\circ}$ * It is hut feldom that the mean heat of the fevereft weck in the winter, falls more than 7 or 8 degrees below the mean temperature of the whole month. This will give 49 degrecs, as the mean temperature of the fevereft week. in the winter at Grard Cairo. And this cannot be greatiy different from the temperature of the winter, in the land of Paleftine. From this way of computation, we thall have 84 degrees of Farenheit's thermoneter, as the alteration which has tiken place in the feverity of the wiuters in that couniry. fince the time of Mores.

The climute in lla!y is alfo found to be very differen now, from what it was 18 centurtes ago. Virgil,the celebrated poet. was diltinguined allo by his knowledge in agriculture. In his Georgics he is frequently giving advice for the fecuri y of caulc, againft the dangerous effects of icc and fnow. His directions were defigned for the country round Mantua or Nap'es, his rative place. in the latrude of $42^{\circ}$. Mentioning Calabria, the molt fouthern part of ltal, he fpeaks of tne freezing of the rivers. as an event that was ommonly to be expefted. Pliny, Juvenal. and Elian, writers in the firtt and fecond centuries, fprak ot ice and fnow as what was common in Italy. One of thefe writers, Elian, ras a chapter which confifts alrogether of inftuctions how ofilh for eels. when the water is covered rvich ice. The desere of cold neceffarv to ffect liss, cannot be efimated at a iefs degice than 25. Fiom the meteor Inglcal obfervations which were made at Rome in tne year 1782 and 1783 , it apears that the mean heat in the month of January at that place. is now 46 degrees; and that the mean heat of the coldeft week in the ivinier was 42 degrees it 17 degrces greater than that, in which the permanent freezung of rivers akes place. The change of climate therefore 11 Italy during the laft 18 centuries, cannot have been lefs than 17 degrees; but from the inaccuracy of the ancient accolints it may have been many more.

A fimilar change has taken place in the country round Confantinople, and the Euxine or Black Sea. This sve collect from the works of Ovid. This celcbrated poet was banifhed to Tomos, by the Roman emperor. This place is in the latitucie of $44^{\circ} ;$ and lies sear the coalt ot the Euxine Sea. The poet fpent leven years in his barifhment at this place, about the middle of the firft ccutury. He informs us that be faw the Euxirie Sea covered with ice: That he walked upon this ice; and that oxen and carriages paffed over it. He goes farther, and adds, that when he called for vine in a fevere feaion, it was prefentea to him in a thate of congelation : And that the fnow in many piaces, was never dilfolved during the fummer feafon. Tournefort obferves that in tije days of Conftantune, the ftreight of Byzantium was frozen over: And that in the ved 401 , the Euxine Sea was crivered with ice for 20 days tegether. We have not any meteorological oblervations to ftate with exuctrefs, what the prefent tempera ure of that alimate is. But nothing would be more uncommon and extraordinary, than to fee this fes trozen over now. In 1667 , the Turks were greatiy stloninged at the appearance of fome ice at Conltatuinofle: And in all the adjacent country, inliead of a frozen lea, frozen wine, and perpetual fnow, they have now a fine modetate warm climare; one of the mott luxuriant, and delightful, that is to be found upon the lace of the ea th. So far as we can judge from the gencral phen mena, the change of the climace there, has been lully equal to what has tdksu place in Italy.

* Voyagc, Vol. I:

* Ephern. Soc, Metor. Palat. ODlervationes Romanx, Tom, II \& III. 
The fame alteration has been obfcrved upon the Alps and Appenines. Thele are the higheft mountains in Europe, and divide Italy from France, Switzerlaud and Germany. The march of Harnibal's army over thefe mountains, was one of the molt memorable exploits of antiquity. In the ir accounts of it, Livy and Polybius in aimoft every line, are mentioning the extreme difficulty and fufferings whech arofe trom the levere frofts, ice and frow. Thefe montains are eafily paffed now. Armies have frequently croffed them without any uncommon fufferings, from the time of Francis the filft.*

The change of climate has been alfo very remarkable in Germany. Two circumfances have marked this with certainty. By the account of Dio. dorus Siculus: 1. "The grcat rivers which covered the Roman provinces, the Rhine and the Danube, were frequently frozen over, and capable of fuppurting the molt enormous wcighis. The barbatians who often ehole that fevere feafon for their inroads, tranfported without apprehenfion or danger, their numerous armies, their cavalry, and their heavy waggons over a vaft and folid bridge ot ice. Modern ages have not prefented an inflance of a like phenomemon. 3. The reindecr, that ufelul animal, from whom the favage of the north derives the beft comfort of his dreary life, is of a conftitution that fupports and even requires the moft intenfe cold. $\mathrm{He}$ is tound on the rock of Spitzerg, within ton degrees of the pole; he feems to delight in the frows of Lapland and Siberia. But at prefent he cannoc fublit, much lefs multiply in any country to the fouth of the Baltic. In the time of Cælar, the reindeer, as weil as the elk and the wild bul!, was a native of the Hercynian foreft, which then over?hadowed a great part of Germany and Polard."'

Thefe accourits will affift us to form fome general idea of the climate of Germany at that lime. The freezing of the Rhine and the Danube is mentioned, as an event that was annually to be cxpected; what the barbarians always found to take place in the fevere feafon; and to fuch a degree, as to afford them a certain and a fofe paltage for the heavieft burthens, and for the largett armies. This account of the ftrength, firmnefs, arid duration of the ice, cunveys the idea of a winter equal in all its effects, to that which takes place in the uncultivated parts of North America. The rivers are here confantly frozen every winter. The inhabitants find by conftant experience, that at that fej fon of the year they can tranfport their heavieft effects, and the greateft weights, with fafety, ccrtainty and convenience. The mean heat of our winters in fuch places, is from 15 to 20 degrees. In fuch a coid, the rivers and Ireams will be fo conftantly and fteadily frozen. that the inhabitants find acertain and a fafe palfage every winter, over the rivers and lakes. This feems to have been very much the ftate of the ancient German winter. From the obfervations which were made at Vienna. laticude $48^{\circ}-12^{\prime}$ rorth, in the years 1779 and 1780 , it appears that the rnean heat there in the month of January was $27^{\circ}, 5$; in February it was $33^{\circ} .23$. At Ratifon, latitude $48^{\circ}-56^{\prime}$ north, in the years 1781 \& 1782 , the mear heat in the month of January was found to be $30^{\circ} .52$; that of February was $30^{\circ}, 76$. At Manheim, latitude $49^{\circ}-27^{\prime}$ north, in the year 1781 and 1782 , the mean heat in the month of January was $35^{\circ}, 08$ : in February it was $35^{\circ}, 8.7$ The mean of thefe, $3^{\circ}, 3$ in January, and $33^{\circ}, 26$ in February, will accuratelv exprefs the prefent temperature of the German yinter on the Danube and the Rhine. The time when the barbariaus bes=

* Phil. Trans. Vol. LVIII, for $: 769$, p. 58, \&cc.

+ Gibbon's Roman Hillory, Vol, I, p. $3 \frac{4}{4} 6$.

$\$$ Ephem. Soe. Meteor. Palat. Iom, I, II, III, \& c,

OI. I. L 3 
gan their inroads into the Roman provinces was about the year 222. A6. cording to this computation, the change of climate in Germany has been betivecn If and 16 derrees, in 15 and a half centuries.

The other inftance mentioned by the hiftorian, and which ferves to mark the climate in Germany in the time of Cxfar, was the appearance of: the reindeer. The warmeft countries in which he now refides, are Sweoen, Rugitia \& Lapland. From she obfervations made at tho. latitude $60^{\circ}-27^{\prime}$ rorth, from the year 17.50 to 1761 , the nean heat in the month of January, was found to be $19^{7}: 5^{8}$; that of February, was $2 !^{\circ} 3^{8}$. At Peterfburg, latitude $59^{\circ}-.56^{\prime}$ north, from the year 1762101777 the mean heat in Jautary, was $10^{\circ}$; in February, the mean heat was $16^{\circ}, 46$. The mean of thefe, $14^{\circ} .8$ in January, and $18^{\circ} .9$ in February, is the temperatuse of the winter in that part of the glnbe. * Thefe are the warmell chmates in which the reindeer does now fubfilt. It may thesefore with much probability be inferred, that this was the temperature of the German winter in the days of Cafar, 18 and a half centuies ago. Hence the alteration of climate in Fermany during that fpace of time, has been about 16 degrees. It feems to be a confirmation of the truch and propriety of thele different methods of computation, that they bo'b afford much the fame refult.

From thefe accounts it appears with a decilive evidence. that the c!imate, in the courfe of feveral centuries, has remarkably changed at Paleltine, in Italy, around the Euxine fea, at the Alps, and throughnut all Germany. Through all this vall extent of country, the climate is now become 16 or 17 degrees warmer than it was 18 centuries ago. The continent of America in fimilar latitudes, is niil lubject to a great degree of cold. If the meteo. rological obfervations which have been made ai Willamfburg, Cambridge, Quebec and Hudion's Bay in America, be compared wi.h thofe which have been made at Algiers, Rome, Poiktiers and Solyfkamfki, places whole latitudes are nearly equal ; $f$ it will be found that the European continent is nnw 12 degrees warmer than that of America. Many inquiries and fpeculations have been propoled to account for this extreme cold of America. Frnm the accounts whicl have been mentioned, it appears that 17 or 18 cen'uries ago, the coniment of Europe, inftead of being 12 degrees warmer. was !ubjęt to a cold 4 or 5 degrees grcater, than that which now takes place on the continent of America. The proper inquiries therefore feen to bs, whence is it that the European continent is become fo much more mild and temoerate than that of America?-Whether the latter will not in a courfe of time become equally warm and temperate as the former? - Whether the climates of boch will not gradually becume more Equal, uniform and moderate, than they now are?-And. whether culti. vatinis is fufficient to account for thefe changes? For whatever the caufe may be, the fact feems to be certain, the heat of all that part of the earth, of which we have any ancient accounts, has keen increafing from the earlies: ages.

* Kirwan's eftimate.

Algiers, laticude $3^{\circ}-49$

Rome

Poidtiers

So!yikamiki

$41^{\circ}-54^{\prime}$

$4^{6}-39^{\circ}$

$59^{\circ}$

M. H.

$72^{\circ}$

$59^{\circ}, 5$

$53^{\circ}, 8$

$32^{\circ}, 5$ 


\section{No. III.}

\section{An account of Frggr duy out of the carth at BURLINGTON. CHAP. VI. p. 154 .}

THE accoun's which natural hillery has recorded of the difcovery of loads and frogs, in fi uauons in which it has been fuppofed it was impoftible they fhnuld exitt, have bcen of a fingular and extraordinary kind.

A very remarkable infance of this nature, has lately fallen under my own obfervatimn. On October ath, 1807, Mores Catlin, Elg of Burlington, was digging a well a few ods diltan trom his dwelling houfe. His houfe was ahout twenty rads fouth of the College. on a haid gravelly fisi and on the highelt land in the rielghborhood. Whan the workmen !nd dug abont five teet below the furface of the ground, they found fix frogs, which did ust appear to be in a torpid or weak ftate; hut as foon as t?ey were thrown out ot the earth, dilcovered the full powers of activity and health. Two of thefe frogs lay together in the earth, the others werefepasate : molt. or a!l of them were covered, or lay under linall ftones. October the $3 \mathrm{sh}$, two more of the lame kind were found; feparate, but un. der Inall fiones as before October the 1 ath, in the morning five more were lound, at the dep:h of about eleven feet from the lus face of the ground. T.NO of thefe lay together, the others were leparate; none of them were covered with any ftones, but furrounded with hard gravelly earth. Alexander Callin, Eilq. a man of the inolt refpectable character, affured me, thar he fa $s$ the workmen dig up three of thefe frogs: and that another man was prelent, when the workmen dug up the fourth.

At mv requeft Mr. Catlin prelerved two of them in a tumbler. Eight houss after they were dug up. I viewed them with all the attention ard care in my power. They were of the fame kind as the trogs which are zenerally feen in this vicinity. One of them appeared to have auained ita tull growth; the other was not ot the full fize. Their bodies did not ap. pear to be forivelled, or in any degree emaciated, but full, pitump and healthy. Their eyes were lucid and brilliant, without any appearance of defect. Their limbs fecmed to be in perfect proportion and order; and their claws long. fluder and delicatc. Refpiration appeared to be ftrong and unembarraffed ; and carricd on with as much eale and regularity as in any other frogs. On moving the cover from the tumbler in which they were confined, both of them jumped out from the glafs, and hopped round the roum; and we had to chafe them leveral times round the room before wr. could carch them. They feemed perfectly well to underftand the beft way of evading our purfuit; did not attempt to leap agzinft, the wall or fumiture, but kept in that part of the room where they viere apparently beft fecured by the wall, chairs and tables. Nor have I ever feen more activity, forightlinefs, or ftronger powers of life and action in any frogs, than what appeared in thefe two, eight hours after tley were dug out of the earth ; and had been prcferved in a tumbler, without any kind of food or nourifhment. To render the evidence of thele fdets as cinnpleat as the na-. sure of the fubject would admit, we preferved bo:h the trogs in fpirits and exhibited them to the view of the fludents in the univerfuty; and they are now in poffetron of the prefident ot lhat feminary. The workmen funk the well to the depth of about eighteen fect, but did no: find any more of thele anima!s.

Oztober the $26 i h$, the workmen were digging another well for Mr. Cate Iin, about eighty rods north eat of the College. The foil $w$ as of a loof 
gravelly kind. At the depth of eleven feet, they dug up a frog in this well. Upon examination, I found it was of the fame kind, form, fize and appearance, as the frngs in the other well; and had the fame phenomens of health, vigor and activity. To afcertain the internal Atate and contents of this frog, we opened it. On diffection, it was found to contain a fmall quantity of blood. The heart, lungs and other cntrails, were in a natura! and perted ttate. The inteltines contairsed a whitc mucus, of a middling confiftence. The internal parts neither appeared to be loaded with fat, or emaciated by leannefs; but to be in a fare that denoted regular but moderate nourifhment. And nothing like putridity, deficiency, or decay, ap. peared in any part of the animal. Uncomfortable weather coming ou, the workmen did not fink this well to any greater depth.

It is farcely to be expekted that more compleat evidence ever thould be found attending any inltances of this nature: And whether we can account for them, or noc, their reality carnot, I think, be callcd in queltion.

In what manner fhall we go about to explain the philofophy of thefe frogs; or to account for their formation, fituation, and life?

Could the fe animals have been produccd in luch a fiu uarion by the carth $\vec{?}$ The doctrine of equivocal generation docs nor feem to have any'thing in theory, obfervation or experimcni to fupport it. No one thing in nature appears' to be the refult of chance, or accióent. Every plant, every trce, and every body in the whole fytem of nature, is evidently the refuit of defign, corstrivance, and adjuftment; and appears to be preferved and regulated by flated and permaneus laws. The object or the body is not to be named, in the heavens, or in the eatth, which appears to be produced, to be go. verned, or to be moved by chance or accidcut ; that is by nocaufe, or law at all. Leaft of all is this to be expected in animals, cvery onc of which has an appropriaie form, conftitution, inclinations. and manucr of life, motion, and propagation. That men hould be produced by corruption, or that the rocks and wonds fhould engender hags and tygers, would be an affertion too improbable and ludicrous for folly to make, or for in fidelity ro believe. It has been conterded that infels are bred hy curruntion and putrefaction. Malpigi, Swammerdam, Redi and othershave confuted this doktıine; and flown that it does not agree with obfervation. The sefult of their inquiries and obfervations is, that mon of the infects are derived ex ovo, and that they depofr their eggs wherever they can find a fit place for incubation; in water, fleth, fruits and vegerabies, in cur about the bodies of animals, in the feathers of birds, hair of bcalts, Icalc sinf fithes, and in every accefrble part of nature. Nor will expcsimenthelp the coctrine of equivocal generation in any degree. From the corrutition of a body arifeth not activity and life, but a diffolution of its parts. You cannot reduce a piece of Asth 'to puirefation, and out of that putrid mafs make an animal body, which ftall have a head, a heart, entrails, veins, and blood veficls; all of which are necellary to conftirure a living crcature. Nor can you take a picce of rotten checle. or meat and nrake out of it 2 handful of mites or worms, any more than you can form it inio lions or whales. A doctrine then which has nothing jn theory, obfervation or $\mathrm{ex}$ periment, 10 fupport is, cannot be advanced " ith any apprasace of proiua. bility to account for the formation of thefe trogs.

Cculd they have been picfoved or exilled in the eatth for a long num. ber of years? This feems to have been the cale, ard docs not appear to be contrary to the laws and phenomena of nature. Exery animal that we are. acquainted with, has apparently tw n modes ol exilking. ficeping and waking. TWhen awake, all the fprings of natule $f(c) \mathrm{m}$ to be a alive and in morion: iylien alcep, the orgas of the body icem to be fufproded as to their, 
ativity and exertions, but the circulation of the blond, and the afive powers of life tlil! icmain. And from the one to the other of thefe flates als the animals of which we have any information, have a regular and natural tranfition. When wearied or reduced by activity and exertion, the animal frame relaxes and yieids, and we tind in reft and neep both relief and refrefoment. When the boày has becn relieved and retrefhed by ret, the powers of nature feem to be recruited, the pulfe gradually guickens, the organs of fenfe refume their fundions, aud the animal awakes from flcep. In moft animals, both thefe ftates are neceflary to his heolth and life; they regularly fucceed each other, and the one is as natural and neceffary as the other.

In fome animals this alternate and regular fuccetfion of feeping and wak. ing is either not kept up, or it is fubjeet to very long periods of cime. Bears, Serpents, Toads, Frogs, Flies, and various other animals are known to live through the winter months in a torpid flate. At the approach of cold weather they retire into the earth, to the bottom of waters, or to fome place of fecurity, and do not appear again till the warmth of fpring has foftened and vivified the earth. They then leave their places of concealment, and come forth into the atmolphere; apparently weak at firf, but not emaciated, lean, or deprived of their flch.

During this period of their torpid fiatc, the appearances are, that they exit without any regular fupplies of food; but not without fomething that operates to their prefervation, fupport, nourifhment, or continuation. As nature is not wearing away by continued abtivity, or by conftant perfpiration, it hould feem that it does not reguire conftant fupplies of food, to recruit, what in the torpid tate is not much fpent or wafted. An animal then may exif in the torpid ftate wilhout regular lupplies of food or viktuals, to reftore or recruit that wafte of nature, which al ways takes place in the abtive, but does not feem to have much effet in the torpid fate of exiftence. But till, fomething is neceffaty to preferve the animal in that ftate in which it went to fleep, and fell iato tise infenfible lethargy. In fome animals, wates anfwers this purpole ; in others, earth contributes to the effect; in others, a rock, or a tree, or any thing that tends to preferve and fupport the powers of nature, and prevent their being exhaufted. And to every fpecies of animals, the author of nature feems to have given a faculty, to difcern and felekt what is beft fuited to their purpofe.

How long may an animal exif in a corpid, or in an infenfible ftate? Many of them, we know from oblervation, do annually live one half the year in this fate. We have well attefled accounts of a man living many days in a flate of fleep or torpor : ${ }^{*}$ of flies, immerled and corked up in a bottle of Madeira wine in Virginia, and many monthsafter coming tolife, when the wine was opened in London; + of a toad that lived eighty or a hundred years in the heart of an old oak at Nantz + And if all the powers of animal life may be fufpended in fuch animals for fo long a period, what hould prevent their continuance in fuch a fate for a much longer period of time; for hundreds, or thoufands, or ally given number of years ? Or who would pretend co allign any date, to determine the maximum, to which fuch a fate mighe extend? If all circumflances frould remain the fame, as they were when the animal firt went in the torpid ftate, it does not appear that the powers of life muft scceffarily wafte a vary

\footnotetext{
* Philofophical Tranfactions.

+ Franklin.

Themoirs of the Academy of Sciences for $17^{\prime} g$.
} 


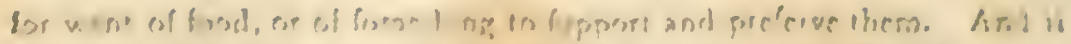

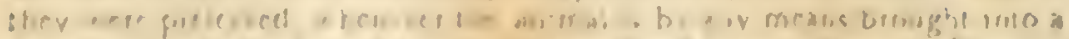

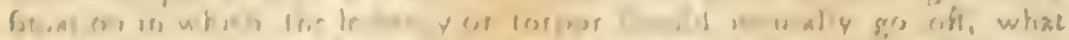

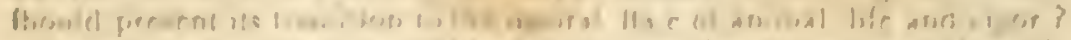

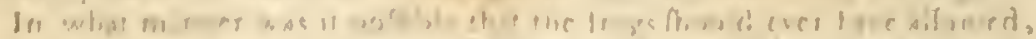

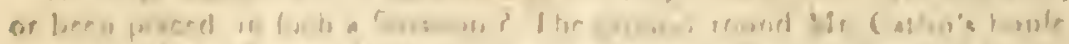

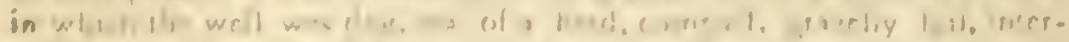

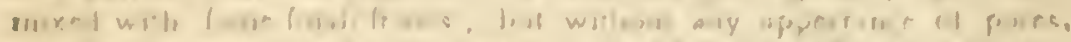

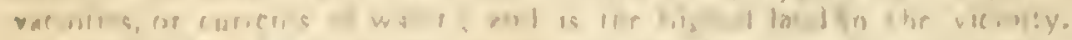

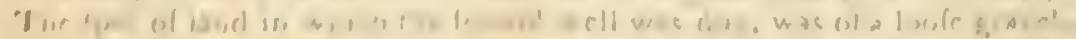

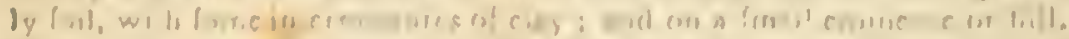

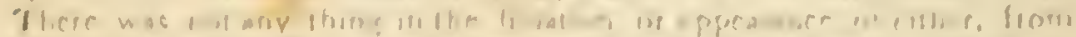

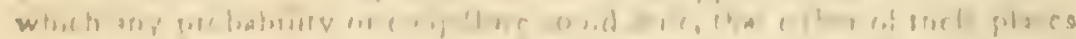

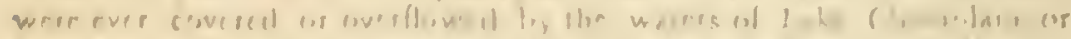

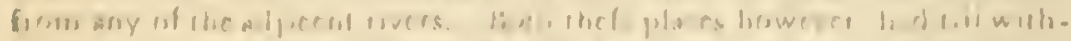

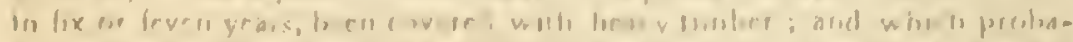

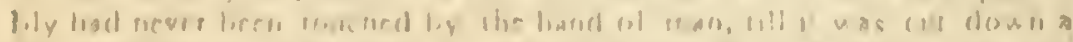

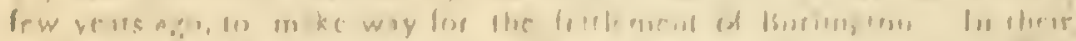

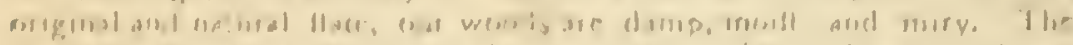

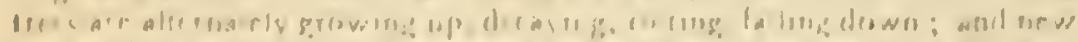

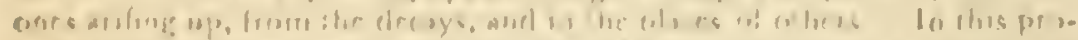

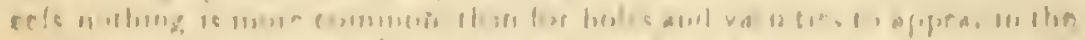

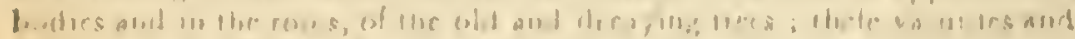

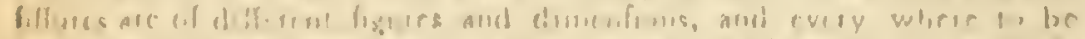

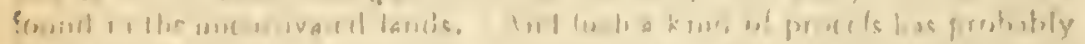

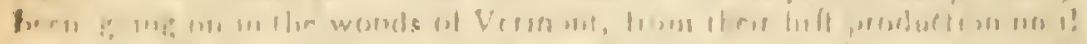

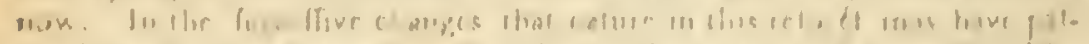

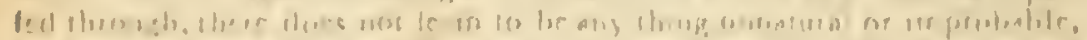

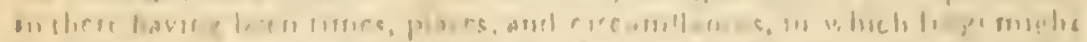

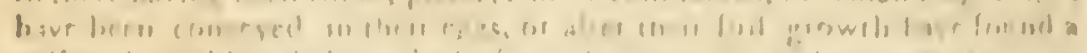

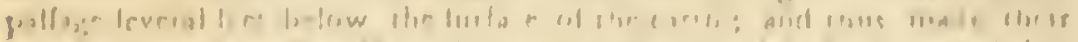

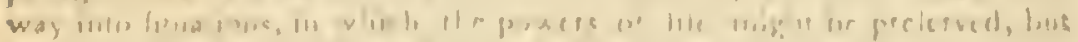

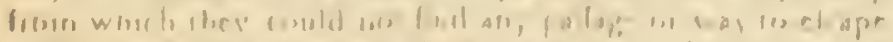

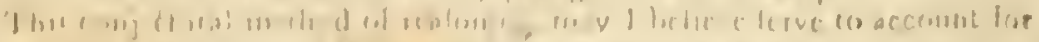

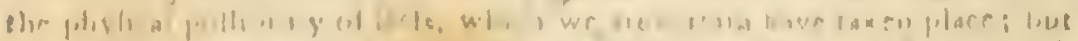

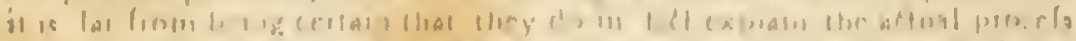

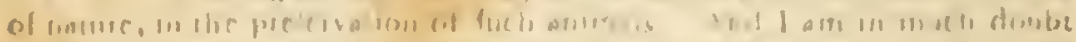

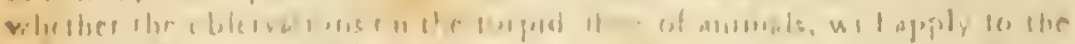

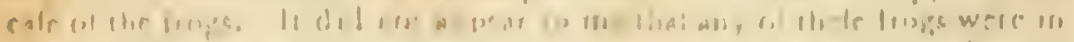

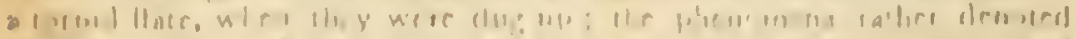

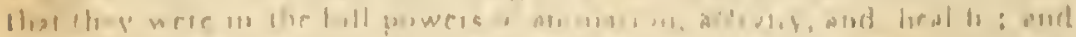

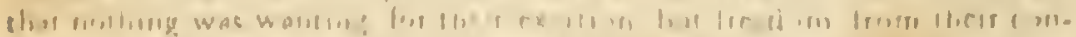

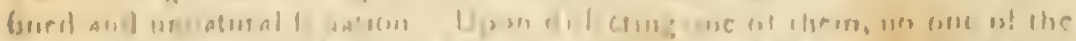

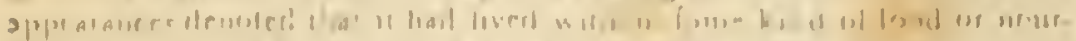

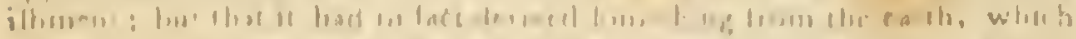

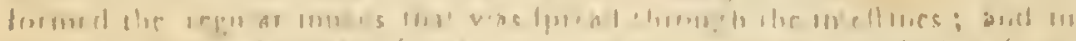

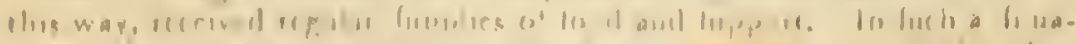

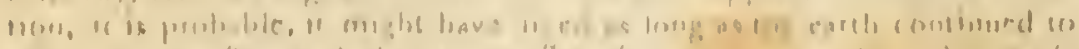

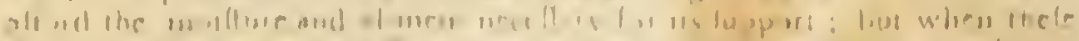

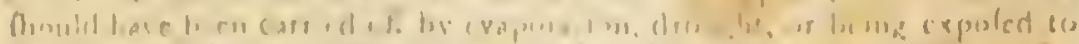

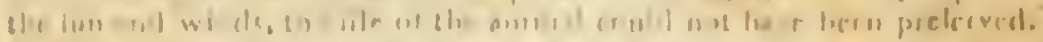

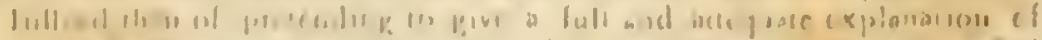

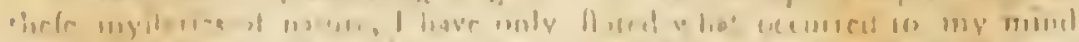

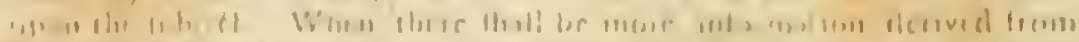

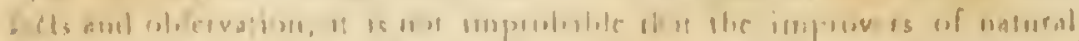

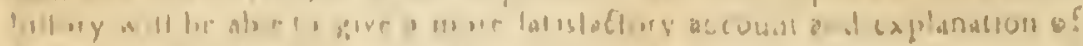

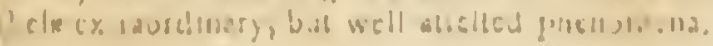




\section{APPENDIX.}

\section{No. IV.}

\section{Doservations on the fafcirating pouver of Serpent:. CuAptrer. V1, 1. 156.}

WhH.N the remaks efpeding the fafeinating power of Sermenta,

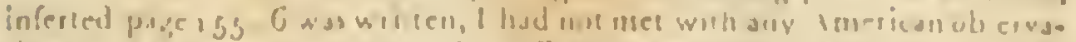

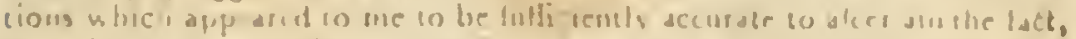

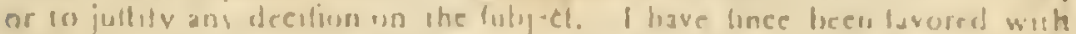

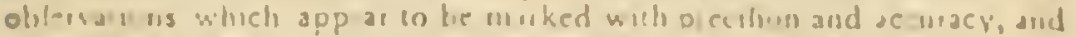

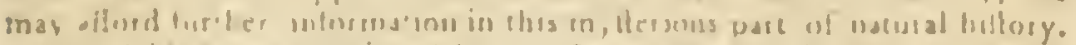

This lubj es nas mentioned by 1)r. C m. 11 . .1ather, fo earls as the geir

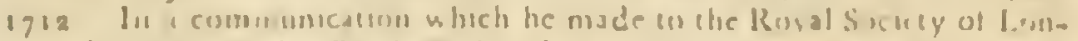

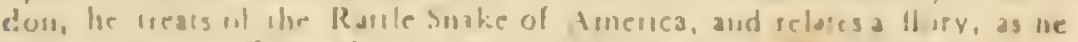

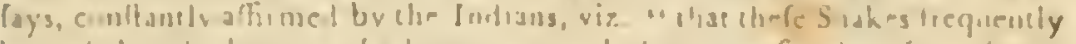

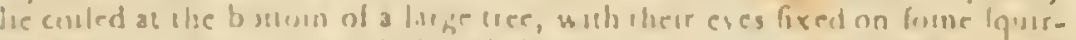

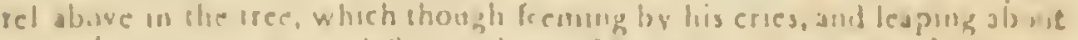

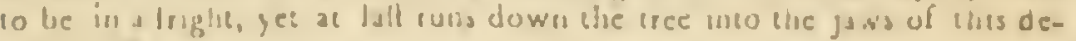
vonser ".

The Hin. Paul Didley af Rnxburn. Mafiechufelis, Fellow of llue linysl Socicty of Lomdun, and Chet Juftice ent the Sipresue Court in Moliach.1-

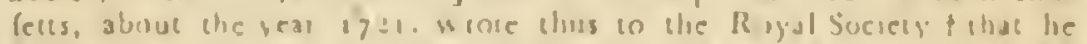
" nenuld noe precent in antwer los the trisits ol every lt ory he tad seard

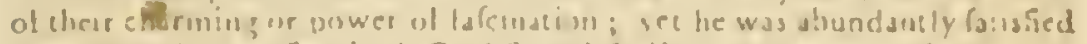

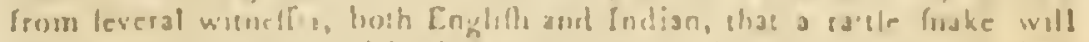

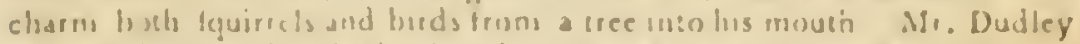

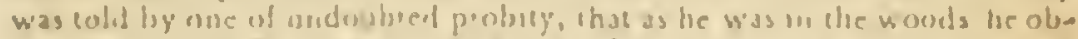

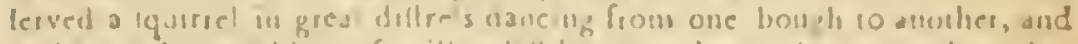

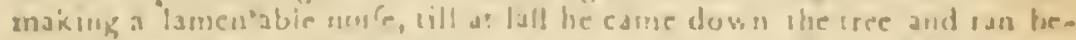

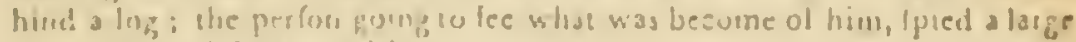
fuake that lo d fwidoived lowin.

"Mir. Wuilley is tha twher confirmed in this telatiens, beesufe his own

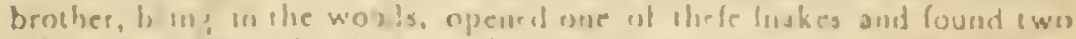

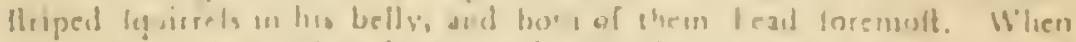

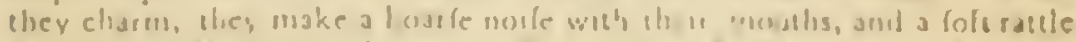

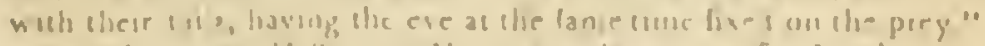

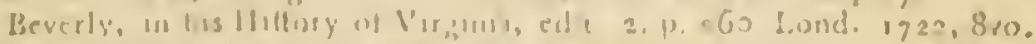

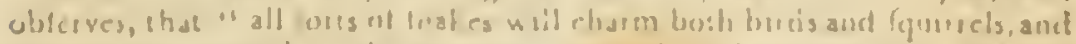

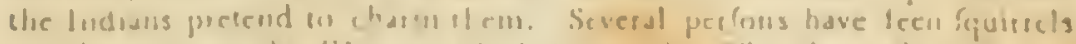

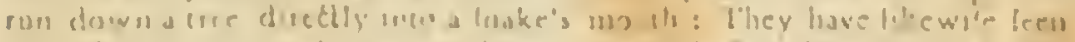

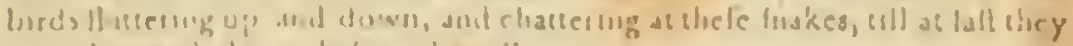

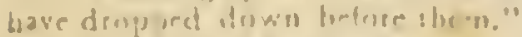

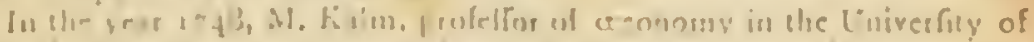

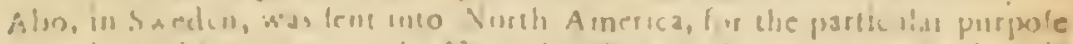

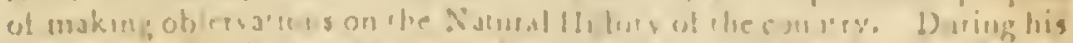

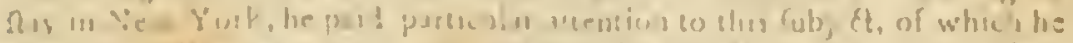

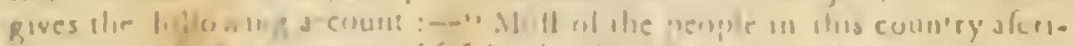

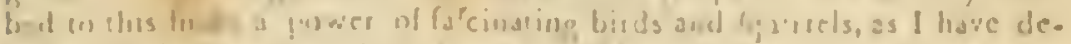

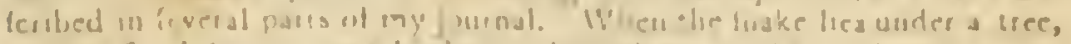

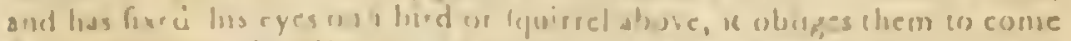

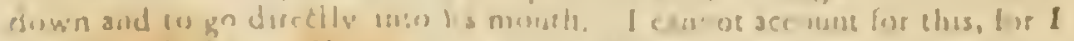

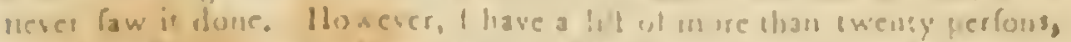

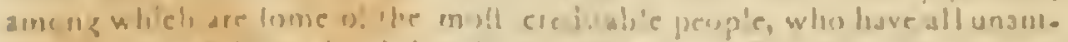

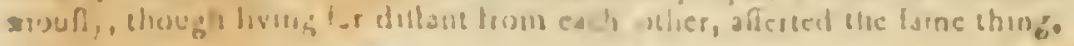

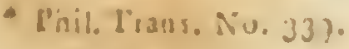
+ P’11. Lians. No. 3; C. P. 29:. 
They affured me, upon their honor, that they have feen, at feveral times, thefe black frakes fofcinating fquirrels and birds which fat on the tops of trees, the fnake lying at ihe foat of the trec, with its eyes fixed upon the bird or finirrel which tits abòve it, and utters a doleful note; from which it is eafy to couclude with certainty that it is about to be fafcinated, though you canrot fee it. The bird, or fquirrel, runs up aid down along the tree continuing its plaintive fong, and always comes nearer the fnake, whofe eyes are unalterably fised upon it. It hould leem as if thefe poor creatures endeavored to cfcape the fnake, by hopping or running up the tree' but there appears to bc a power which with.holds them; they are forced downwards, and cach time that they turn back they approach the nearertheir cnensy, till they arc at lall ferced to leap into its mouth, which ftands wide open for that pup pofe. Numbers of fquirrels and birds are continually running and hopping fearlefs in the woods on the ground, where the fnakes lie in wait tor them, and can eafily give thefe poor creatures a mortal bite. Therefore it feems that this falciration might be thus interpreted, that the creature has firll got a mortal wound from the fnake, which is fure of its bite, and lies quiet, being affured that the wounded creature has bcen poifoned with the bite, or at lealt lcels pain from the violence of the bite, and that it will at laft be obliged to come down into its mouth. The plaintive note is perhaps occafinned by the acutenefs of the pain which the wound gives the creature: But to this it may te objedted, that the bite of the black inske is not poifonous. It may further be objccted, that if the frake could come near enough to à bird or quirrel to give it a mortal bite, it might as eafiy keep hold of it, or, as it lomctimes does with poultry, twift round and Arangle or ftifle it. But the chiefobjection which lies againtt this interpretation is the following account, which I received from the molt creditable people, who have affured me of it. The fquirrel being upon the point of ruming into the fnake's mouth, the fpectators have not been able to let it come to that pitch, but killed the fnake; and as foon as it had got a mortal blow, the iquirrel or bird deftined for deftruction flewaway, and left off their mournful notc, as if they had broke loofe from a net. Some fay, that if they only tousched the fnake, fo as to draw off is attention from the \{quirrel, it went off quickly, not ftoppinc till it had got to a great diffance. Why do the fquirrels or birds goaway Io fudderily, and why no fooner ? If they had becn poifoned or buten by the frake belore, fo as not to be able to get from the eree, and to be forced to approach the frake always more and more, they could not, howcver, get new ftrength by the fnake being killed or divested; therefore it feems that they are oniy inchanied, whillt the lnake has its ejes fixed on them. However, this lonks odd and unaccountable, thongh many of the worthieft and molt reputable people have related it, and though it is founiverfally belicved here, that to doubi it would be to expofe cre's felf to general laughter."

Thefe obfervations clearly fnow what has been the general fentiments of the people upon this fubjea, from the earlieft fettlement of the country. The opinion fon med by the orizinal inhabitants could not be derived from books, fpeculations, or philofophical ihcories: but mult have been formed from what they had themlelves obferved and feen. Thofe of our anceltors who frequently met wish thefe ferpents in the woods, found the indian accounts to be true, and embraced the fanc opinion, and it fecms to have been admitted by both, as a well known inaticr of fact.

The accounts howcucr which they have given us of this matter, do not amount to the highelt evidence the fubje e niay admit. They clearly Thow what has been the gencral ientiment in the country refpeding the takt, but they do not contain the obfervations and declarations of perfons, who have themfelves becu the obfervers or actors in any of thefe extraordinary tranfactions. The following communications will be found more circumllar. tial and particular. 


\section{Arlington, Feb. 1795 .}

IN your Natural Hiftory of Vermont, you have mentioned lome. thing concerning the rattle and black fnakes charming birds, which does not reduce the matter to abfolute certainty. If you think the following account on the fubject any way iuterefting, it is at your fervice.

TIMOTHY TODD.

WHEN I was a lad, in ranging the fields for birds eggs. I heard a thrufh making her ufual noifc of diftrefs, and fuppoled fome boy wastaking its neft or young: Afproaching towards her noife, I difcovered het circling the air not many feet from the ground, hewing every fign of diferefs. Having viewed her fome minutes, being unable to accourat for the phenomena, I at length difcovered the largeft black fnake which I had ever feen, lying fretched out under the centre of the bird's motion: Being ftruck with horror at the fight, I ran off, and believe the rsake did not fee me. My father. hearing the circumfance on my return home, told me the fnake was charming the bird. - Some years afterwasd, when nearly arrived to the age of mantiood, walking in a field in Connedticut, near a fmall grove of wainut trees, I faw a fparrow circling the air jun in the margin of the wood, and making dreadful moans of diftrels. Immediately the former circumfance occurred, and I approached with cauticn within twenty feet of a black fnake, about feven feet long, having a white throat, and of the kird which the people there call rumers, or choking fnakes.* The fnake lay ftretched out in a ftill pofture; I viewed him and the bird near half an hour. The bira in every curn in is flight defecnded nearer the objeet of its terror, unil it approached the mouth of the ferpent. The Inake, by a quicl: motion of its head, feized the bird by the feathers, and plucked out feweral. The bird flew off a few feet, but quickly returned. The fnake con inucd to pluck the feathers at every flight of the bird, until it could no longer fly' : The bird would then hop up to the fnake and from him, until it had not a feather left, except his wings and on its head. The fnakc now killed it by breaking its neck, by an amazing fudden mosion; he did no: devour it, but caft it a little off, and continticd his fation. Now the tragedy was again to be repeated; for another bird of the fame kind, who had thewn figns of difrefs during the firt tragedy, was fafcinated to the jaws of the monter in the fame circling manner as the former, and fuffered the lols of fome feathers. I could no longer ftand neuter. With indignation I attacked the hated reptile, but he efcaped me. The liviog bird was liberated from his fangs. The dead one I picked up and Shewed to my friends, deftitute of feathers as before mentioned.

\section{$0 \% 0 \% 00 \% 0 \% 0 \%$}

DEAR SIR,

$$
\text { Brandon, Fuiy I, I795. }
$$

I find you folicitous of information refoeting the charm of the anke or ferpent-perhaps the following account. which I received from the mouth of a lady, wbo was herfelf an unlapoy fufferer, may no: be azils or unacceptable.

* It is faid that this kina of fnake wiil entwige himfeif round the body or neck of a perfon, and cholic him: It may be a rulgar errnj: 'This, however, is ccrtain, they will often purfue a perfon who rurs from them. I have heard that they frequently charmed fquirrels and tome other arimals, and in fome infarees the human fpecies: An inflance or wo which happeoed to boys, will perluaps before long be prefented, with the ptoper ycuchers.

$$
\text { VOL. I. M } 3
$$


If I have ant iorgezten, her name was Finney, of Lanilngburgh - The told me about fice years ago, that not long before that time, as fhe was walking by the corser of a certain fenec, not far from North River, the was fud. denly zmuled with the chirping of a frake, whether a black or ftriped one, $I$ havctorgoten. As the drew nigher to the fence, the difcovered the frake, pitching is head to and fro, through a heap of dead bruth; deeply en. gaged with its charms, the forgot her'elf, till a neighbor pafting by, broke her attention: When the felt herfelf as though the had been among poifonous herbs, itching, \&z. which iffued in a long fit of ficknefs, which her phyircian afcribed to the fafcination of the fnake, lad the had not per. feetly recovercd when I faw her.

$$
\text { I am, \&c. }
$$

\section{WATKINS.}

\section{$0 \% 00 \% 00 \% 00 \%$}

\section{Extract of a letter from Somucl Beach, dated Whiting? Fuly 24, I 795 .}

IWHEN a lad, I hived with my father in the then provinee of New Jerfey, where the black frake, with a white throat, commonly called the racer, as well as the ractle fnake, and other ferpents, are frequently met with; and I never remiember to have heard any ane difpute the power of charming telanging to feveral fpecies of ferpents, but more eorimon to the black fnake, called the racer, which I have twice fecn in the operation.

The followirg ftory, I have otten heard related, and to which people in general gave ercdit, of a frake's falcinating a young lad :- Two boys were feat into the wonds to look for cattle, and comug to a piecc of oper land, where fome colliers had been a hort time beforc burning caal, they fopped ro liften for the bells that were na the cattle they were in fearch of ; and near where they flood, they oblerved a very large fnake, of the racer kind: One of the boys obferved to the other, that if he would watch the motion of the frake, he himfelf was determined to fee if it would fafeinate or charm him; and faid, "you have a ftick in your hand, and if you lee me like to be too much inju:ad by the fnake, you may kill him, and relieve me." This the other agreed to do: when the firt advanced a few fleps nearer the fnake and made a ftand, lonking fteadily on him; - when the fnake obferved him in that frtuation, he raifed his head with a quirk motion, and the lad fays, that at that inllant therc appeared fomething to fld in his eyes, which he could campare to nothing more frmilar, than the rays of light thrown from a glafs or mirror when turned in the fun thine; he faid it dazzled his eyes, at the fame time the colours appeared very bcautiful, and were in large rings, cireles, ot rolls, and it feemed to be dark to him every where elle, and his head began to be dizzy, mueh like being crer fwift running water. He then fays, te thought he would go from the fnake; and as it was dark every where but in the circle, he was feasful of treadina any where elfe; and as ghey ftill grew in lefs circumfercuce, becould fill fee where to ftep; but as the dizzinels in his head frill increafed, and he triec to eail to his comrade for help, but could not fprak, it then appeared to him as though he sas in a vortex or whirj.. pool, and that every turn brnught him nearer the centre.

His comrade, who had impatiently waited, obferving him move ob. liqgely forwards to the rigitat and left, and at every turn approaching nearcs the fuake, and making a ftrage groaning noile, not unlike a perfon in a f:t of the night mare, he faid he cnuld ftand ftill no longer, but irnmediately ran and killed the faake, which was of the largeft lize. 
The lad that lad been charmed was much terrified, and in a tremor ; his thirt was in a few minutes wet with fweat; he complained nuch of a dizzinefs in his head, attended with pain, aud appeared to be in a melancholy, flupid fituation for fome days alter.

I have heard the flory fo ofien related by different ferfons, that I canso but give credit to it.

Sis,

\section{$0 \% 0 \% 00 \% 00 \% 00 \% 000 \%$}

I HAVE obferved that you are defirous of colleding informar tion relative to the fafcinating power of lerpents - If you thiuk the follow. ing infance wortby a piace in your ufeful collefion, you ate at liberiy to infert it.

When I was a boy about 13 years of age, my father fent me into a field to mow fome briars. I had not been long employed; till I dircovered a large ratt!e fnake, and looked round for fomethung to kill him; but net seadily difcovering a wcapon, my curiofity led me to view him. He lay coiled up, with his tail erect, and making the ulual finging noife with t: ratules. I had viewed him but a fhort time, when the mott vivid asu lively colours that imagination can paint, and far beyond the powers of 4.5 pencil io ini:ate, among which yellow was the moft predominant, 3 a the whole drawa inon a bewiching varicty of gay and pleafing forms, bict: prefented to my eyes; at the fame time, my ears were encharted writh th: molt rapturous ftrains of mufic, wild, lively, complicated and harmosious, in the highef degree melodious, captivating and enchanting, far beyon: any thing I ever heard before or fince, and indecd far excseding what my imagination in any other frtuation could haveconceived. I feit mylelf i:acfitibly drawn toward the hated reptile; and as 1 had beez often siled to feeing and killing rattle fnakes, and my fentes were fo ablorbed by the gay vifion and rapturous mufic, I was not for lome time apprelicufive of much danger; but fuddcnly recollexting what I had heard the Iudians relate (but what $i$ had never before belicucd) of the facinaling power of thefe ferpents, 1 turnce with horror from the dangeraus fcene; but it wa ant without the moft vioisnt efforts that I was able in extricate mylelfo All the cxertions I could make, with my whole frength, were hardly fusficient to carry me from the fcene of horrid, yet pliafing enchartment; and whilc I forcibly dragged off ray boriy, no head lcemed to be irrefintibiy drawn to the enchanter, by an invifible power. Aad I fully belicva, that in a few moments longer it would have been wholly eut of my pow. cr to make an exertion fuficient to get a wyay.

The latter part of the fcene I was extremely frightcaed, and ran as falt as polinile towards home. my fright increafing with my fpeed. The firf perfon I faw was my uricle, who difcovering my fright, ran (1) meet me, and anked the nccafion of it: I told him i had been frighiened by a rattle fnake; but was in too grcat a perturbation to relate the whoic. Ile rallied me for my pufillaninity, and took me by the hand, and we went to the place where the fnake was flill lying, which was fonn difpatched by iny uncle. I then rejated the fory to him, and bave fluce told it to many other perfons.

The night following i never clofed my eyes : The fame focuecontintaally haunted my imagination. Whether the agitation was occalinned metely by the recollchion of what had pafted, or whethes the operation of the charm flill liad "ime real cffe? upon the nervous fyen, I cauno: etermine.

E.LIAS WILLAKD.

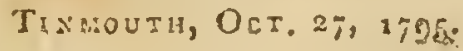


UPON a careful examination of the above accounts, I cannot fee that any obfcrvations are to be expected upon this fubjeet, more accurate oparticular; or which could probably be attended with more convincing atteftations or eridence of their being authentic and correkt. Dr. Todd, is a phyfician of nuch ability and diftinction, formerly prefident of the medical fociety, and one of the Council of this State, and now refsdent in Connecticu:. Mr. 1. Watkins was a minifter of the golpel at Brancon; and now lives in the flatc of New York. Mr. Beach has been aitentive to the natural productions of the country, and now lives a: Whiting. Mr. Willard died at Tinmouth a few years ago, and was a man of much infor. mation, virtue, and veracily. And I cannot difecrn any article or circum. fance in their telations of thele maters, which appcars to be of a doubtsul, deceptive, or fallacious nature. They relate fimply and merely to matters of fact, and are declarations of what they heard, oblerved and telt; matters of which they celtain!y were adequate ar:d conpetent obfervers and judges.

Among a number of accounts of a fimilar nature: I thall only mention one more, which 1 have from Col. James Claghorn, of Rutland, which is inferted not fo much with a view to eflablith the fact, but rather as affording fome information refpexting the mance and pincefs of the operation. At Salifbury in Connecicui, fome years ago. where the Colonel then lived, there were two men of the name of Baker and Nichols. Going towards the meeting houfe in that placa, they difcoveled a large sattle. fnake, in a plain open piece of land. The frate lay coiled up in a pofture of defence; to attack him with fafety, they procured a long flender pole or I witch, with which they could reach hitn without being in any danger from his motions. As the fnake could not efcape, they diverted them: felvcs with irritating him with their pole, without giving him any confiderable wound. They hed carricd ou this bufusels lome lime, during which the fnake had reperiedly attempled to fping upon them from his ecils, and to efcape by running; aut citcovcred uncommon appeasances of rage and difappoiniment. Being provented in a!l his attenpts to efcape from, or to bite his oppolers, he luddculy ftetcied himfelf at his fuil jength, and fixed his cyes on the man whrs us itching him with the end of his pole. The inake lay perfefty 11,4 , and M!r. Nichols kept on the fame motions with his fwitch. illur this tcere bad coninued for a fhor: rime, Mr. Niciols feesed is incine his body norre ard more towards the fnake, and begar to move towards bim in a bery fow and irregular manncr. Baker, who llood looking on, noticed thcle appearancer, and called to Nicrols to defint lrom the bufincis, and dipatcli the fuake. He touk no notice of thefe admoricious, buc appearcd to have his whole attersion fixed on the fnake, vas obleıved to be fradialiy moving lowards hino, to have a pa!e afpect, arid to be ir a prolufe fweat. Alarmed wi.h the profe pect, Baker took him by the Moulders. gave him a violem fnake: puiled nim awey by force, and cuquiscd what was the matrer. Nichols, thus forced trun the fcene, usade an uncornmon mouriful noife of difircls, ap. peared to be uncommonly ard univerlally aftected, and in a few minutee rcplicd to the enquirier that he did not ksow wlat ailed him, that hecould sot tell how he felt, that he hao never fclt fo beforc, that te did not kno:w what was the matcer with lim. but was very utwell.

The above accounts relatc onily io the falcisating rower of wo of the ferpents of America. Singular and excraurdinas as itey may appcar, wa have very authentic relations that the fame rowcints found in lome of the Erpeats of the other hesaifpiarc. 
ne very remarkable account of this kind is from Italy by Dr. Sprengell. At Milan be found a viper catcher, who feldom was without fixty or more vipers alive, kept together in a back room, open at top; he had them from all parts of Italy, and fold thein dead or alive according to the ules they were defigned for. Having one day got a female viper, big with young, we catched forne mice, and threw in one at a time; ainonglt all that number of vipers, which were upwards of fixty, there was none of them in the leaft concerned himfelf about the moufe, till the pregnant. fcmale viper and the moufe interchanged eyes; whercupon the moute llattled; but the viper raifed her head, and turued lier neck into a perfect bow, the mouth open, the tongue playing, the cyes all on fire, and the tail ercet: The moufe feemed foon recovered of his fright, would take a turn or two, and fometimes more, pretty brikly round the viper, and giving at limes a fqueak, would run with a great deal of fwiftnefs into the chops of the viper, where it gradually lunk down the gullet. All this while the viper never firred out of her place, but lay in a tirg."

It is to be obferved, that no viper wi'l feed when confined, except a pregnant female viper. The Doctor faw the lame thing at Bruffels, whcre a foldier had catched a large viper big with young.

\section{$0 \% 0 \% 0 \% 00 \% 00 \% 0 \% 0 \%$}

[From the TRAVELS OF L.e VALLIANT IN AFRICA.]

IN the additional volumes of the travels of Le Valiiau une, Ifrica, appear fome very ftriking facts relative to the falsinating power of lerpents. Two of them are authenticated on the evidence of the author himfelf, and the other is fantioned by his belicf in the veracils af the relator.

The infances produced by Le Valliant are briefly as follon":

Firf inftance. - "One day, in one of our excurfions in han'ing, we perceived a motion in the branches of one of the trees. Innediately we heard the piercing cries of a hrike, and faw it tremble as if in comvulfins. We firft conceived that it was held in the gripe of fome bied of prev: but a clofer attention led us to difoner upou the next bratich of the tree, a large ferpent, that with thetched out neck, and fiery eyes, hougn p rfeet. ly ttill, was gazing at the poor animal. The agony of the lund was turtible; but fear had deprived it of ftrength, and, as if ticd by the le : it seemed to have loft the power of fight. One of the coinpany ran for a fufee; but before he returned, the mike was dead, and we o.ip thec the jerpent. I requelled that the diffance between the place where the bird tad experienced the convulfions, and that occupied by the lerp:nt $m \cdot g h t$ be meafured. Upon doing fo, we found it to te three feet and a half, and we were all convinced that the fhrike hid died neither from the bise, nor the poifon of its enemy. I ftripped it alfo before the whole company, and made them obferve, that it was untouched, and had not reccived the nighteft woursd."

Second inftarce. - "Hunting ore day, in a marhyy picce of ground, I heard, all at ouce, in a tuft of reeds, a piercing and very lamentable cryo Anxious to know what it was. I ftole loftly to the place, where I precived a fmall moufe, like the thrike on the tree, in agonizing convulfions, and two yards farther a ferpent, whofe eyes were intently fixed upon it. The moment the reptile faw me, it glided atvay; but the bufraefs us done. Upon taking up the moufe, it expired in my haud, without its being poffible for me to difcover, iy the moft aticntive examination, what had osw alioned its death."

* Ihil. Tranl, No. 39?. 
Third infance. - "The Hottentots, whom 1 confuited upon this incident, expreffed no fort of aftonifhment. Noihing, they faid, was mor commor; the lerpent had the faculty of attracting and fafcinating fuch animals as it withed 10 devour. I had then no faich in luch power; but fome time attcr, fpcaking of the circumflance in a company of more thas ewculy perlons, in the number of whom was Colonel Gordon : a captain of his regiment cnnfirmed the account of the Hottentots, and affured me it was an eveut which happened very frequently. 'My teftimuny, added he, 'ought to have the more weight, as I had once nearly become myfelf a victim to this falcination. While in garrifon at Ceylon, and amufing mylelf, like rou, in hunting in a marfh, I was, in the courfe of my fport, fuddenly feized with a convulfive and involuntary trcmbling, different from any thing I had ever experienced, and at the fame time was ftrongly attracted. and in tpite of myfelf, to a particular fpot of the mailh. Directing my eyes to the fpot, I behcld, with feelings of horror, a ferpent of an eriormous fize, whofe look inftantly pierced me. Having, however, Lot yet loft all power of motion, I embraced the opportutuity before it was too late, and faluted the repile with the contents of my fulec. The zeport was a talifman that broke the charm. All at carce, as if by miracle, my convulfion ceafed; I felt in fell able to fly; and the only inconven. jence of this exp"aordinary adventure was a cold fweat, which was doub:o Jefs the cffect of my fear, arid of the violent agitation my fenfes had undergore."

"Such was the account given me by this oftecer, I do nat pretend to vouch for its iruth; but the llory of the moufe, as well as of the thrike, $k$ aver to be a lact."

The lame phenomena then have been obferved in Europe, Afia, and Afri:ca, as wel! as in America. It then we tom nur judgment from obferva. kion, the conclufion will be, that in cvery part of the earth, the ferpent has difplayed different powers and faculties, from what heve appeared in oth. er animals.

\section{$0 \% 00 \% 00 \% 00 \% 000 \% 0$}

\section{Remarks and Conjectures on the above Accounts.}

1. From the above accounts it can hardly be doubted. but that the viper, the black, and the rattle fuake, have a power to affect bitds, tquirrels, and the human race, 11 an extraordinary and powcrfil manuer; fo as to caule them to approach withiti the reach of their devouring jaws. To plilofophers, who derive all their information trom their books, and to men who determine from theory ard is $11 \mathrm{er}$, the whoic affair paftes for vulgar delufion and fo!lv: Nor will it ever appear probable to any perfon who is accuftomed to no other way of reafoning, than the inclaphyfical method of detcrmining fakis by realonings a friti?, that nature has given to the ferpent verv different powers from thofe which the has imparted to any wher fpecies of animab. But it certainly is not finm the men of metaphviral lizeory and fyttem, but liom the careful obfervers of nature, that the mol important information is to be expected. And it will be difficult 10 find any defeet in the oblervations that have been inentioned, or any cilcumflance that denotes them to have been delulive or lallacious. I muft thercfore admit it as a uocll attefled? fact, that nature has imparted in the ferpents mencinned above the firgulas and extraordinary power of facination; or affeEting ollec animais in fire? maner as to caufe them to approach within their rearh, 
2. This power, whatever it be, feems in be exerted by means of the eye of the fnake. "The eye of this reptilc, fays Mr. Dudlev, (the ratlefnake) has fomething fo fingular and terrible, that there is no looking. Redfaftly upon him."* All the accounts agree that no uncommon elfect is perceived, till the eye of the arimal is fixed on that of the ferpent. It Thould fecm from Mr. Beach's and Mr. Willard's accounts, that the eye of the fpectator is no fooner fixed on that of the inake, than the moft lively and beautiful colours are feen, in the moft engaging and cnahaning forms, in large rings, circles, or rolls : and that thefe circular appearances of the molt bcautiful light and colours a re gradually diminithing in their circum. ferences-Hence the encircled animal is conltantly laking irregular or circular motions, within the circle of apparent light ; both of which bccome more and more contracted, till they are brought to a centre or clofe at the head of the inake.

3. The operation whatever it may be, takes, away the fenfes, or Rupifies the animal, on which the operation is carried on. This was the cale, and to a high degree, with all the perfons mentioned in the above accounts. Thcy found themfelves violently affeEted, but new not what was. the matter. At the beginning of the fcene they feemed apprehenfive of danger, but foon loft all power, and all inclination. to make any oppofition; Nor was there, in a few moments, enough left of the rational or animal powers, to reflect on their fituation, difcern their danger, corrrive a method or make any attempt to elcape. Deprived of fenfe and reafon they rcmained lubject to a power which they could not compreherd or oppofe, and get in great and extreme difrefs.

4. Can there be any fubtle effluvia, poifonous exhalation, or Ruoifying virus, emitted by the eye of the ferpent, and reccived by that of the en-. chanted aniınal, equal 10, and producing the uncommon effe Ats which have bcen mentioned. This feems contrary to all the other apocarances of animal nature; and yet the phenomena feern to indicate fuch a phylical kind of operation. The body of the bov at New-Jerfev was covered with a violent fweat. His head was affected with a dizzineis, and pain : nor did he recover his health for fevera! davs. Wr. Wr.tard e ca. ped before the fcene was completed ano found himfelf too mucin aff eted co fleep the riext night; but could rot delermine whether it was owing to the fright, or to a phyfical effect on the nervous fyftern. In the lady at Lanfingburgh, the fafcination iffued in a long fit of fickisels, which was not cured in five years. Thefe arc phenomena which feem rot only tó denote phyfical operations, but fuch as were of a very powerful and extraordinary nature; and which feem to refemble what was laid of the bafa. link by the ancients.

5. Whether there is anything in the powers of otleer animals that refermbles this faculty in the ferpent, I am not enough acquairted with natural hiftory to determine. Some perfons have mentioned the Dog and the, Cat, as exhibicing fome appearances of a fimilar power; but 1 do not find any fufficient evidence in poof of it. Nor do I know of any thing in naive that approximates to a fimilarity, except the rcfemblance in the effict which light appears to have on fome animais.

Some infects w!ll fly into a buraing candle, and remain in the flame till. elueir wings are conlumed, and their bodies buined. The effeet of light is alfo apparent in forne of the birds. In a barn in which the f:allows rea fide in he fummer, if a burning candle be carried in the right, the fwallows will foon leave their places of reft, and gather round the light. The

* Phil, Tranf, No. 376, p. 293. 
fifhermen in aimoft every country, frequently avail themfelves of the fans: difpofi in in fome fpecies of fifh; and expect to allure them to their boate or weapons by the light of a lanthorn or fmall fire. The fportfmen in fomc countries, effect their purpofes by the reflection of light. "There is a method among lportmen of taking larks by a net and looking glaftes, which they expre's by the name of Doring. Five or fix looking glaffes are fo fixed 10 a ftick, as in reflect the light upwards. Theftick in which they are fixed is fo made as 10 revolve on its axis by means of a fring wound round it. When the machine is thus twirled round. the light is reflected upwards by the mirrors in quick and conftant fucceffion, and to a confid. erable extent. The bird is faid to be enticed or invited by the glime mering of the light, till it defcends and lights near the looking glaffes, and is then taken by the net." "Thelark catchers in forne countries," fays Brydone, "are fo dexterous at this maneuver, that with a fmall mirror they throw :he rays of light on the lark, let her be ever fo bigh in the air; which by a kit.d of facination, brings down the poor animal to the foare."

Such an effect does not feeni to be alogether difimilar to what takes place in the facination of a bird by a ferpent. The lad at New-Jerfey faid that "at the infant the fnake $f_{x} x e d$ his eye upon him there appeared fomething to falh in lis eyes, which he could compare 10 nothing more fimilar. than the ra; s of light thrown from a glafs or mirror when turned in the fun thine; he laid is dazzled his eyes \&s." Nor do the eyes of the ferpent feem to be unfilted to produce lome fuch effect. There is fomething in the eycs of a iarge rattle fnake that is fo fierce, ardent, and pene. Erating, that it is painiul to look upon them; and we do in fact experio ence phyfical effeEts, which to fay the leaft, are agitating and very uncomforcable.

6. Whence arole the idea of any uncommon fubtilty or cunning in the ferpent? There does not fcen to be any thing in the whole race, which has proved agrceab!e, ufelul, or beneficial to mankind. The higheft degree of malice and danger werecxpreffed by the ancients, by the phrafe of a ferpent that would not be charmed; that is phyfically divefted of his difpofition to bite. An ${ }^{\text {f }}$ Act it has happened that this fpecies of animals in almof every country, has been confidered as the emblem of fomething wife or excelient.

Straboand Eufcbius tcll us that at E!ephantina, the god that was fuppofed to reprefent the architect of the univerfe was aciored tuder the fir gure of a ferpent. In his hiftory of the creation, Mofes reprefents the ferpent, as more fubrile than any heaft of the field, which the Lord God had made. The Jewin and the Chrillian thoology both fuppofe that the form of the lerpent was that whi h the tempter chofe, to give the greatef probability, influcree, and fuccels to his defigns and attempts upon the huo man race. The Saviour of mankind in his day, gave it as a command to his dircicles, to be wife as fernents, but harmlefș as doves. The Egypo tiars twined two 'crpen's logether rotind the globe, probably to reprefent the equilibrium of the fyntem of the world. In India, the priefs put the ferpent into the hands of thcir disinities. By a circle made by a ferpent with his tail in his mouth, the ancierts meant to reprefent eterdity; by beirg coild rousud a fick, he was fuppored to cxhibit the god of healch: and we have made him the repicleritative of jullice and prudence. The Jews, the Greeks and the Mufulmen, have all viewed this reptile in a

- Supplement to Chambers's Dietionary. Article Doring.

7 Fridone's tour through S'cily and Malta. Boflon Edit. p. 15:

Fraim 58. 3, 4: 5 . Jescmiah 3. 27 . Ecclefialtes $10,1 x$. 
Angular light; and he has every where been oled to denote fomething valu. able and uleful.

W'hence arofe all this celcbrity, and thefe ideas of his wifdom or cunning? And how came fo many different nations 10 affix the ideas of wifdom, power, and utility, to a race of animals that do not appear to be either friendly, or of any advantage to mankind? I cannot afcertain either the origin, or the caule of the reputation :hat has been afrigned to a repile, which appears to be the molt ufelefs, odious and obmoxious, of the whole animal race; nor can I determine whether the ancients were acquainted with his fingular powcrs. They have been obfercyed in Europe, A fia, Africa, and America ; but 1 do nor find any thing in the earlieft writings, thofe of Mofes or Homer, that intimate any fuch fufpicion. Homer fpeaks of enchantment, as fomething that was well krown and generally believed in his dar. But it was not the eye, or a ferpent that was invefted with this dreadful power; it was the voice and the fongs of the Syrens, that carried unavoidable eachantment and deflruetion. But whatever were the fentuments of the ancients refpeding this animal, I think it can hardly be doubed but that he docs now difeover a different facalty or power from tho?e of other animals. It is to be crpected that thefe powers fhould be moft frong and apparent in thofe countries, where he exifts in the greateft eafe and vigor; and has becn tle icall diftubed by cultivation, or by man: and to me rhe evidence is convincing, that the ferpent has difonvered fuch powers in Anerica. But 1 am fo far from compiehending this myferious article of natural hiftory, that 1 mult refer the fubject to the inveltigation of men of better abilitics and more information.

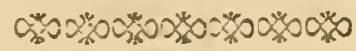

THE TIVO-HEADED SNAKE.

NATURALISTS have been in doube whether the two-headed fnake was a monftrous production, or a dintinet fpecies of ferpents. Thefollowing curious obfervation of Capt. William Baker, feems to decide the point. Mr. Baker is well known to the Author, and there is no room to doubt the authenticity, or the accuracv of his account.

In Auguf 1,63 , in the tow'n of Sherley, county of Middlefex, and Pate of Mafiachufetis, 1 found a large vater frake, as 1 was mowing in a meadow, formerly flowed by bearer. I took out of the belly of the fnake fixty young ones; they were about ten inches long, except one of them, which had two heads, four eyes, two tongues, and appeared to be about two inclies longer than any of the reft. I hewed the fnake with two heads, to a great many people; but as I uas but a boy, and at that sime cnes not that I could have preferved it in fpirits, I did not attempt keepires it, which I am very lorry for, as the fight of him would prove to the world, together with this account, that the two headed fnake is of a mon. 1: ous production.

RUTLA:D, DEC, 16, 1795 .

W. BAKER?.

\section{0}

\section{No. V.}

* Difiertation on the Colors of Men, paricularly on that of the Indians of America. CHAs. VIII. P. 237.

COLCRS OF MEN.-ONE of the moll curious phenomena that belongs to the natural hiftory of man. is the color with which ke is marked. Every vol. I. N 3 
object which we behold, appears to be of fome particular color. In animals thefe colors are extremelv various, different, and beautiful; and fometimes they appear to be variable. Man, like other animals, is diftin. guithed both by a peculiarity, and by a variety of color. In Europe, he appears white: In Africa, he is black : In America, his color is red : In Afra, a variety of colors are to be found upon the human countenance. There are ocher thates and tinctures to be found in each quarter of the globe, befides thofe mentioned above : But thole that have beer mentioned are the moft general and prevalent colors, under which man appears, in the four general divifions of the globe.

VARsety of Colors.-The molt difinguining, permanent, and general colors of the human fpecies, and which are at the greateft extremes' from each other, ate hlack and white. Between thefe, or rather as different degrees and variations of them, are all the other colors of the human countenance: And they mav be reduced to fwarthy, red, copper, and brown. Black is the color of the Africans under the equator; of the inhabitants of New Guinea, and New Holland. A fworthy color includee the Moors in the northern parts of Africa, and the Hottentots' in the fouth. ern parts of it. Red diftirguilhes the Indians of North America, The fame; or perhaps more accurately a copper color denotes the compiexion of the Indians of Afia. Brown comprehends the Tartars, Perfians, Arabs, Africans on the coat of the Mediterranean, and the Chine?e. The inhabitants of the illands in the Pacific Ocean, are alfo chiefly of this color. Under this color is comprehended all thole different thades, which are denoted by olive, chelnut, and deep yellow. A lefs dark color, or brownifk, will beft exprefs the complexion of the inhabitants in the fouthern parts of Europe; the Sicilians, Abytrinians, Spaniards, Turks, and alfo the Samoicdes, and Laplanders. White is the color of molt of the European nations; as Swedes, Rufians, Danes, Englifh, Germans, Poles, \&c. Kabardinfki, and Georgians. It is obfervable that all thefe colors are included between the two extremes; or rather they are different degrees or variations of black and white.

Change of Cozor.-A change of color is always produced by the marriage or mixture of perfons of different complcxions. Thus the offfpring of the European and the negro, is of a yellow complexion ; lefs white than the European, and lefs black than the negro; or rather of a dark cream color. This race are numerous in fome parts of A merica, and are called Mulatioes. The offspring of an European and an Indian is alfo of a cream color; and more light than the mulatto. Thefe are called among the Spaniards Mefigos. The effect and operation of this change of the original colors, in the climate of America, is always in favor of the fairer complexion; and never approaches towards, or ends in the darker color. This change and alecration of color, when it is left to its natural tendency and effect, is extremely now and moderate in its operation: and it is not until after many years, that the full effect is produced. In the Spanith feltlements, this mixed race has fo multiplied as to form a confiderable part of the inhabitants: And the feveral fages of variation in this race, with the gradual alteration of thade until it ends in the European complexinn, have been well afcertained, and are now perfectly well underfood. Thofe of the firlt generation are confrdered and treated as negroes or Indians. In the third generation the Indian color difappears. It is mot until the fifth defcent that the deeper black of the negro is loft. At" the end of thefe different periods, the offspring can no longer be diftingusitned from the European; but is confidered as fuch, and entitled to at 
xheir privileges.* - In this change of color, produced by the molt power. ful of all natural caufes, the mixture of perfons of different complexions: fo gradual and now is the operation, thai the black mut be lubject to five divifions, and the operation mult be continued through five generations, betore the color is completely changed.

SEAT of Color. - That the different colors of the human fpecies are feated in the $\mathrm{k}$ in is very apparent. The thin confifts of three folds or coverings. The firft is a very fine and tranfparent integument, and is white in people of all colors. The fecond is a cellular membrane, differently colored in different perfons. The third is alfo white. It is in the fecond of thefe, that the color is feated. In black people, a very able anatomift obferves that the fixin is much thicker and larger, than in white ones; the cellular membrane. in the latter being a thin mucus, but in the former a thick membrane. In whites this feat of the color is tranfparent, and either totally deprived of veffels, or only furnifhed with a very fow; as the yellow color appearing in jaundice, vanithes on the caufe of the difeafe being removed, which is not the cale witl ftains from gunpowder, or fimilar caufes. - Hence, he oblerves, three caules may be very readily aftigned, which will operate to deftroy the pelucidity of the Rin, and ive it a brown color, and render it thicker. Thele are the heat of the fun, the accels of air, and naftinefo. And in general any thing that operates to pro. duce or to deftroy the peiucidity of the $f k i n$, will tend to vary and change the color of the human body.

COLOR CONNECTED WITH CIIMATE.-Among the caufes which may affect the color of the human body, it has been generally fuppoled that the influence of heat or climate, has a conficierable effect. Concern. ing this influence or cornexion between color and climate, the following obfervations may be made.

1. Different colors are beft fuited to different climates. In all the plants and animals which are Ipread over the face of the earth, there is lomething by which they are peculiarly fitted to the climate and country, in which they are placed. One kind of vegetable requires a great degrce of neat : Another fluurithes the beft in a temperate and cold country. It is the fame with animals. Some are fitted tor the heat of the torrid zone. $O$ :hers require the fevere cold of the frigid zone, to give then their greateft perfection. To all thefe animals, nature has given the proper clothing; which admits of no other variation than what the feafons of the year require.-Man is an animal made for cuery climate : Inftead of being formed for the torrid or frigid zone, he can live, multiply, and arrive to his proper perfection, in any climate: And it is left to his own rea!on and induftry to provide himfelf with fuch clothing, as his condition may reouire, in every climate through which he may pals; or in which he may injourn. And yet there is fomething in different $m \in \mathbf{n}$, which qualifies and fits them for one climate, better than for anothes; and that is, coior.-The man whofe color is black, is better fuited to the extreme heat of the hotteft climate, than any other of ibe human race. This has been long known and oblerved in the climates of Ainerica. The negroes of the Weft India inlıds, in the Spanifn dominions, and in the ftates of Gcorgia, and South Carolina, are found to bear the extreme heat of the fummer, better than the white people. On the contray, the negroes in :he nortiern ftates of America are more tender than the whice people, lefs

* Voyage de Ülloa, 1. 2\%. Robert́an's Hiß. Amer. 11. $3^{60}$.

+ Doctor Hunter. 
able to bear the feverity of our winters, and more apt to complain, fufier, - and freeze with the cold. - The white men are the reverfe of this They bear the levere winters of Canada, and Rufiia, without much dificulty or fuffering: But in a hot climate they become fickly', and fail fooser than the negroes. Several colonies of white people have fubfined in the torrid zone in America, more than two centuries: And yet they cannot bear the heat, lil:e the original inbabitanis, or like the negroes. The one is apparentiy beft fuited to a cold, and the other to a hot climate. And thefe differcnces are as apparently owing to their color, for they din not appear to bc connedted with any other caufe, or circunntiance. Different colors therefore in the human fpecies, are certainly beit adapted, fitted and fuited, to different climates.

2. There is a tendency in climate to produce the color which it re. quires. Animal heat is derived but little from the fun, or from the atmofphere: but chiefly and mainly from original conftitution. The defign of covering and clothing, is to detain and prelerve the heat of the an-imal body, in its natural fituation, degree and quantity; and to prevent an extreme wafte or difperfion of it. Black readily receives and abforbs the heat of the arimal body ; and in this way tends to exhauft and difperfe it. White reflests and repels the rays of light and lieat more than any other color, and thus prevents and oppofes their paffage; and in this way, tends to preferve and detain the conftiturional heat of the animal body. Hence the covering, which naturc has alfigned to the earth in cold climates, is fnow: By its color it becomes beft of all adapted to prevent the heat from flowing out of the earth into the atmolphere. And hence the covering of moft arimals in the fevereft feafon, and country, is generally white; the color which molt of all prelerves the heat of the animal body, anci prevents irs flowing out. In conformity io the fame law of nature, many animals change their colnr at the approach of winter; aad fromiblack, brownor grev, become white. This is the cafe with the rabbits, loxcs, bears, \&c. at Hudlon's bay, Rufid, and Siberia. From the darker colors which they bear in fummer, they turn white at the approach of wirster ; and remain fo. until the rcturn of fpring. In fuch cafes, climate appeas to have a powerful and a fuciden operation, to produce the colors it reguires.

The change of color in man, is more flow and gradual: It is howevcr. - cerrain and apparent. The white men who are mixh expofed to the heat and rays of the fun, and to the influence of the wind, in lrot leaions lefe their whitenefs, and become brown or red. The inhabitants of Europe when they fettle in New Spain or in the Welt India llands, foon loofe heir. whitenefs, and becume of a brownith yellow. The Europcans who re. fide long in the Eealt Inàics, hecome of the fame cream colored complexion. We have an accurate account of the effect procuced by climaie in South America, by Dr. Mitcliell: "The Spaniare's who have irhahited America under the torrid zone for any confiderable time, are become as dark colored as our'native Irsdians of Virginia, of which 1 my relf have been a witne\{s." * An account from Atrica, is cqually authertic and accurate. "There are feveral other fnall Portuguefe fettlements, and one of fome note at Mitomba, a river in Sicrra Leone. The peuple here called Portuguefe, are principally perfons bred from a mixture of the firf Portuguefe difcoverers with the natives, and now become, in their cornplexion, and woolly quality of their hair, perfect negrocs, retaining hnwever, amattering of the Portuguefe language." + Here the operation of mix-

* Phil. Tranf. No. 476.

* Account of the trade of G. Britain tq Africa, by an African Merchar: 
Sire by marriage, is determined by climate in favor of the African color. There are fimilar accounts of the complexion of the Por:ugucle, who fettled at senegal in 1400 ; and of thofe who are fetiled on the coalt of Con. go. The varying coiriplexion of the Jew's is alfo very renarkable. Defcended from one itock, thicir religion has prevented their marrying with other people. In Eritain and Germanv, they are white. In France and Turkey, they are brown. In Spain and Porlugal, their color is Iwarthy. In Syria and Chaldea, the olive coinr prevails. In Arabia and Egypt, they are of a tawny or copper color. * Among cvery nation they feem to partake of the color of the climate. And one of them, Tudela, relates that his countrymen in Abylinia, have acquircd the dark complexion of the original natives.

It is obfervable that all thefe changes, arc from a light to a more dark complexion. Similar changes have not been oblerved in the negross, that have been brought into the temperatc clima:es of America. It fhould feem therefore that the tranfition is eafier from white to black, than from black to white; or that the negro color is the molt deeply imprefled of any; or that heat has a much more ludden and powertul effeet than cold. It ought however to be obferved that it is onlv in white and lair compiexion:, that thefe changes of color would foou become vifible, or apparent 10 common obfervation. In a dark or black countenance, fmall and gradual variations of thade would not be obferved. I: would not be until the negro had lolt much of his furmer color, that the change would be generally nouced. But 1 much lufpect that there is fomething more curious in this fubject than has been imagincd : That fome of the colors of the human colustenance, are in their owr nature, colors which ase lefs chanueable than others. It feems to be univerfally the cafe, that the black produced by fourhing, or by an intenfe heat, is the molt durable of any color whatever: And ihat white is inore foon and eafily fullied, and changed, than anv of the other colors, with which any obje 8 is marked.

3 It feems to be a confirmation of theis remarks, that the coiors of men. in d:It rent climates, are in tad fuch, as thenfe climates feem to require. Uiad r the equator the dakelt thade, perteet black takes place. The negro of tfrica is placed in the molt interfe heat, that akes place on this glcube; and the color of the negro is the derpeit and darkeft black, that arv where appears on the human countenanec. rielvancing from the equaIn towards the pole, the color of the human fpecies acquires a complexion inor: and mere lizht; until having paficd through all the intermediatc gradutions of thade: it terminates in the whitenels of a temperate and cold cimate. There are indeed variations and exceptions from this, ano from every o:ber genera! law of nature. Intermix:ures of aifferent nacions, mi . gra ion. differences in food: difeafe, clcanlinefs, health and many other local circunfances and caufcs, will produce thefe. As fuch variations are not agreeab!e to any genesal law ol nature, they are ncither cvidences of, or objeftions to fuch laws; bu derive thcir origin from local and particular caufes. - But it is impolibie not to difcern the general regularity, tenden.cy, and effect of the laws of nature, refpecting climate and coior. The moft inienfe black, is the general color of man in the boutcit part of the globe. Where the heat is confiderably abated, the black abulics' 100 , and the color becomes fuarthy. Tothis fuccects the red or copper entor of the calt and weft Inclians; fuired to that part of Alia, where the lisdians bave been loug ixed and permanently fotted. The next gradation is

Buffon Nat. Hilt. Vol. III. 
brown, comprehending the olive, and dark ve!low, A lighter thade, of a brow approaching nearer in whice, diltinguilheth a climate ftill more temperate. The whole terminates in the coldaefs, and in the whitenefs of the European and northern nations; beyond which nature has not proceeded. And where a cuuntrv is of great extent, as India, and China, the color of the fame people is dark in the fouthern, and more fair in the northern parts. Whatever particular exceptons and deviations may be found, the general law of nature refpectun, color, is marked with as much reguiarity, uniformity, defign, and order, as any cther law of nature, which applies to the vegetable or animal world.

4. This operation and effect of climate muft be extremeiy gradual and faw. Whatcver thofe caules are which have fe;ved to form and fix the colors of men, they are caufes which have been in operation, from the beo ginning of the creation or God. If there were any differences in the natural conltitutions of men, fo as to form what has been called different races, thofe differences munt have been original; and therefore as ancient as thofe fuppoled races of men. If the eftet has been produced by climate, this caule mult have been operating upon nations, ever fince their refidence be: eame fixed in any particu'ar part of the earth. The fame remark will ap.ply to any oiher fuppoied caule. Be it what it may, upon every nation whole refidence has been fixed, it mut have bcen operating ever fince their fituation became eftablithed. With regard then to all thofe nations which have long relided in the fame part of the globe, their colors mult be viewed as the effect of canfes, which have been in operation either from the beginaing of the creation, or from the time when they began 10 refide in their prefent fituations, or countries. What then ought to be expected, if any race of men whofe color was already formed, thould be removed to a country, where the tendency of climate was to reverfe the former effects, and change the color which had been long fixed ?-Could it be expected that the power of climate to change a color long formed and fixed, could be exerted in lefs time than it had required to produce and to ettablith it ? viould it require lefs time to remove an eftablifhed color, and to produce a new one, than it did to produce and fix the firrt? So far as we can dérive any information from the ordinary courfe of nature, we eannot con: ceive that the color of the negro, could be chaiged inte that of the whice $m a n$, in a lefs period of time, than it had taken, to produce and eftablifn that color at firnt. It is nuch more probable, that a longer period of time apould be necrffary io eradicate the firft, and produce the fecond, than was zequifite to form the complexion at firf. Thofe then that mean to inquire sarefully inito the operations and effeets of nature, muft put on the patience of the antiquasiau. and learn to compute time with the altronomers. The impatience of many leads them to expect that climate fyould wndo that in three or four gencrations, which naiure has been confasliy at wor. to effect, from her firt origin until now.

I will venture to propole a conjectural eftimation, not becaule I thiok it approaches very near to certainiy or decifion, but becaufe I caunot find any thing upon the fubjet, that has a greatcr appearance of probability. The ment powerlul of all the caules, which have been found to change the eomp'exion of man, is that of mixture by marriage. In the negro color, this requires five generations, and five divifions, hefore the African blacksefs is lon in the European whitenels: In the le is dark complexion of the Indiar, it requiresthree ginerations, and thee divifions, to produce the fame efiect. The time of one of thefe generations may be eftimateri at a. hout tweaty five years. The time then waich nature requires to effeet this. change of colcr from this caule, would be one hundred add twaty five 
years, for the negre. A thirty fecond part of the whole color, upon this fuppofition is done away by fome other caufe, fay that of clinuate. If the whole effet had been produced by climate, and in this proportion, the time neceffary to have completed the effect would have been four thou' 3 na years. By the fame method of conjetural eftimation, the tim necclfary co reduce the Indian to the European color, would be fix hundiec years. The difficulty and uncertainty attending this mechou of forming an eltimate, is not that it can give the period of time trio long, but that it affumes what cannot be afcerlained by obfervation. It is not, and probably cannot be made certain by oblervatini, that a thirty fecond part of the negro color is done away by climate, or that it is done away at all, when the negro complexion is lupp, fed to be completely changed. It is not probable that if a thirty fecond part of the daik color remained, it could be readily diftinguithed by the eye. But uncertain as the data are, they are fufficient to thow that the operation of climate, in any view in which the matter can be confidered, is extremely gradual and now.

5. This influence of climate, whatever it is, may be increafed, or it may be re!arded, by the operation of other caufes. The color of the fkin may be affected and changed by other caufes, as well as by heat and cold. If there be any thing in the common method of living, in being conflantly expofed to the fun and wind, in the ule of paint ard oil, or in habitual cleanlinels or filthinefs, that tends to darken, or to render the complexion more fair ; this, may operate either with or againlt the influence of climate, according as the nature and tendency of fuch cufom or practice may be. ind we ought not to alcribe that 10 , or make that any objection to the infuence of climate, which may be derived from other caufes. Thus in Greenland, the influence of climate is in favor of a fair and white com. plexion: but in the conflant application of greafe, oil, and filthinefs, to the human body, there is another and a more powerful caufe to effect its color, than climate; and which, akting in conftant oppofition to it, gives to the counteriance a fallow or dirty olive complexion. Such caufes may aft with a force and povier, equal or fuperior to that of climate; but they are not equally permanent, univerfal, or invariable. There is no error more common, or more apt to deceive us in contemplating the natural hiltory of man, than to a!cribe that to one caufe, which is derived from or produced by the juint operation of many. Whatever tends to render the \{kin more or lefs tranfparent, will afręt the color of the human fpecies, as certainly as the climaie in which they are placed.

Color AND CLIMATE OF THE INDIANS OP AMERICA.-There is no fuhjeet in philofophy lo well underftood, but. chat a number of queffions and inquiries may be propoled refpetting it, which do nor admit o? 2 fatisfactory or complete anfwer. Arsd this will always remain to be the cale, becaule our knowledge of nature will never be equal or commenfitaie to the !ubject. But there is one inquiry arifing here, which demands our careful attention: How does the climate arid the color of the Indiaris of America agree with this, or with any other fuppoled law of climate? The Indians were fpread over the whole continent of America: They dwelt in every habiable climate from the equator to the pole: And they were of the fame color in every place. In the greateft heat under the equator, and in the fevereft climates of Canada and Hudfon's bay, they were of the fame brownifh red.* This appears to be the proper Indian coior in

* It has been cuncmary to write in this language, but we are fat irom being ccrtain that it is either accurate, or proper. It has been taker cor granted, but it has nover been exaccined, whether the India ectcris 
every part and climatc of America. Are the climates of America differen: from thofe ol the other contment? Or whence is it that the counexiors which takes place berween clinases aud color in the o:her parts of the globe, is not 10 be fonnd amoug the Indians? This curinus phenomenon - has occafioned inucli ir.guir: and fpecula:ion: Can the cau'es of it be found, in the obferva:ions which have been alrcady nentionted ?

1. The Indiancolor is very" evideraly, the masule of black and red. The color, which an inrenle heat produces upon all bodies 10 which $i$ is applied, is black: And it is as namal to expett it how lit have this aft th upron the human bodi, as upon anv other bodi"s. The color whic" is roudiced upon he human bod, by itvirg much in the open air, expoled i, he in. Huence of the fua and wirl, is res. The white men who live iu tu in a

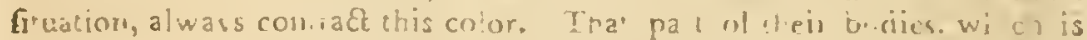

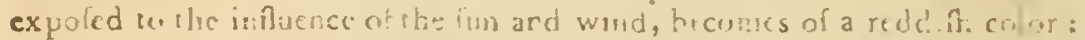

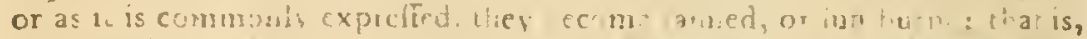

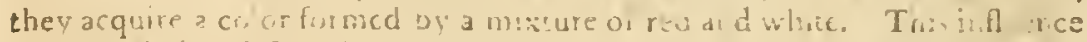
of the nisizand fon, in producing the red commiexion, is founc io be much the fame in fummer and sinter: The white man is nearl, as rruch and as foon lanued, in the winter as in the fummer It feems thisefore that the production of this red cnlor, does nn depend upon climaie, heat, or cold, buc upon hilit; the trabit of liviug in the open ais, and having the body expofed to the conttan influerce of the fun and wind. I he Indian color then feems to have been lormed by the nuxture of I wo different eolors, black and red : and so have been dorived from two powerful caufes, climate and hulut: Cau'es dillinet from one another, a: d the lat:er p10: ducing neasl: llic fame effed in cvery climate.

2. This color of the Indians was probably completely formed, uben they firf came into America. The'y were of the fame color as the Indians, and fouthern Tartars in Alia; and appear to have been delcended from them. Thcir color thercfore was completely tormed aud fixed. before they came into Anerica. This color feems to have beca derived from the warm climate of : fia; and from the habit of iiving conftantly cxpofed to the fun, and to the op:n air. The colorthus formed and fixcd, they would naturally convey to their offspring. And as there were no other people with whom :hey could have any intercourfe, ihere could be no change or alteration of color, produced by a mixiure of parents of different complexions. Their colortherefore muth have been fettled, and uniform: And the whole effect of populacion mult have been co fpread, propagaie, and preferve it. The cficet of climare then upon the Indian in America, would not be to pichuce and form his culor; but either to freferve, or to change it.

the fame in every part of America. An aceurate and inquifitive obferver, M. de le Pinto, who commandid for feveral years at liatagroffu, a Eortugucfe fettencru in the inserior parts of Brazil, where the indians are nume. rous, and $n$ talieied by their inicrcourfe with the Europeans, noted a difference in their complexicns: "They are all of a copper color, with fome diverfity of thade, rot in proportion to their diftance from the equator, but according to the decree of clevation of the tcrritory which they inhabit. Thofe wholive in a hiyis country are airer than chofe in the marthy, low lands on the coaft." - " "uherthn's Hil. Amer. I. 460 . On the northweft part of the Acterian enutinent, it has been found, that "the complexion of the Indian is iigh cr than that ot the fouthern Indians, and fome of their women have wiy cheeks."-Morle's Geog. 1. 99. 105. Edii. 1793. Of the Indians of Paraguy we have this accomt: "They are sencrally of an olive complisisu. fume datker, others lighter, and fome as white z! "iz Seaniards."-Ibid. p. 8:. 
3. No part of the climate of America was fufficiently hot, to change it inco an intersfe black. It is only in the moft intenfe heac of the hottent climate, that the extreme triack of the negro is formed. The climate of America under tle line falls far thort of this. "While the negro on the costl of Afica is fcorched with unremirting heat, the inhabitant of Peru breathes an air cqually mild and temperate, and is perpetually thaded under a can pry of grey clouds, which intercept the fierce beams of the fun." * The climate in cuery part of the torrid zone in America, is much more mild and temperate inan the fame latitude in Africa or Afia. In a country where the hotten climate is fo moderate, it is not to be expected that the Indiat: color thould be changed into extreme black. No part of the climate was hot enough to produce this : Ard any fmall variation in the Indian countcuance, would not be readily or calily difcerncd.

4. The cliange of color mot naturally to be expected would be of the contrary kind, wot to black, but to white; at lealt to a lighter thade than what took place under the equator. If there be any influence or tendency in extreme cold to produce a fair and white complexion, this might have becn expected; for there are no colder climates upon the face of the earch, than tholc of the northern parts of America. But whatever might be the infuence of the climate to produce fuch a complexion, the Indians made ufe of ecueral ccrtain and conftant methods to prevent it. Onc, was their contant habis of living and wandering about in the wonds, expoled to the full force of the winds and fur : Another, was their extreme and perpetual filth, and dirtinels: A third, was their habitual ufe of grcafe and paint. It wris their univerlal cuftom to anoint and rub their bodies with the greafe and oil of the bear, bcaver, mufkrat, and other animals; and to mix the greafe with different kinds of paints, and gums. This practice was probably defigned to protect the body againft the extreme variations of heat, cold, and muifture, to which they were conltantly expofed. Nor ennid they have provided any better defence againt heat, cold, rain, and infects, than thus to cover their bodies with a glutinous kind of varnith: And in doing his, they took a fure and a certain mechod, to fix and preferve their color from any approaches to a white, or to a fair complexion. When extrene dirtinefs was added to the greale, oil, and paint, neither climate or any other caufe could produce a fair complexion, until thefe were removed and difufed. 'Thus in the Indian cuftoms, and method of guarding the body againft the effects of climate, the Indian himfelf was taking contians carc that nothing frould change the,color of his $\mathbb{k i n}$, or make it more traniparent.

5. Where thefe cufloms have been difufed; the Indian color has been found to b: charigcable. It has never been decided whether the Indian color is exactly the fame in every part of America. No sccurate comparifons have cver bcen made between the color of the Indians in the hotteft parts under the eginator, and thofe in the remote regions of Canada and Hurifon's bay. "Their colors have neyer been compared io any accurate and known flandard; and fmall variations in a dark complexion, would not be al matter of common oblervation. But whether the Indian color be the fame in every part of Anerica, or not, it is certainly more changeable, and not fo derply lixed, as that of the negro. Many families of the Indian tribes are to be found in feveral of our rowns. Some of thefe are at Cape Cod, and Riodc liland : A confiderable number of them, are at Natic, and Stockbridge, in MafTachufetts. Their habits and manners of life are differenc from thofe of the Indians, who refide in the forelts. They live

* Rabertfon's Hift. A merica, I, 2.53.

$$
\text { VOL. I. O } 3
$$


in houfes, have a fixed piace of refidence, and have much difufed the cuitorit. of paiais and oils; and their complexion differs much from that of the iribes who yet remsin in their ancient, and original tate. The reddith caft is abaicd. The tawny afpect appears inore dull, pale, and clouded The crimfon mixture has difappeared, and they have approximated much nearer to the color of the hunter among the whites, than the tribes who retain their ancient cuftoms and habits. This change of color in the Indians who have lived long amorng the whites, is apparent to common obfervation. And it is apparently derived from the change in their manners, cuttoms, nd habits. This change of the Indian complexion, clearly hows what has been the effect of cuftom and habit.

6. In the northern parts of America, therc are permanent phenomena, which will terve allo to thow what has been the effect of climate. The Efquimaux in the northern parts of America, are a people remarkably differcnt from the Indians, which cccupy the other parts of he continent. There is not much room to doubt, but that they were derived from the r.urthweit parts of Europe; are the fame pcople with the Greenlanders, Laplanders, Zemblans, and Samojeds; and like them, were defcended from the Tartars in the ealt. Their defcent then was probably from the fame nation as the Indians. But while the Indian tribes have by cuttom, preferved their red complexion, the Eiquimaux have acquired a fallow olive, or hrownith color; more inclining to the Eurnpean whitenefs, than to the brownith red of the American. To what caule can we aferibe the lighter color of this branch of the Tartar race, but to their more northerly and frozen fituation? They have adopted the fame cuftoins and habits, as the Indians. They rub and anoint their bodies, with greafe, the fa: of the feal, and train oil; and are a, filthy as the Indians. Not only fo, but they drink the fat of the feal, and their train oil, and efteem it the moft pleafant liquor. Can it be doubted what mult be the effect upon their color ? It operates againft the infuence of climate, in that part of the earth where climate operates mof powerfilly to produce a white complexion. The influence of the two caules is divided, but the balauce is in favor of climate, and the European complexion. Thus in two very extenfive and numerous kinds of men, derived from the fame nation, climate, cuftom, and habit, in one part of America, have produced or preferved the dark: crimfon of the Indian; but in the moft northerly and frozen parts of the continent, the fame caufes have elablithed the fallow olive coior of the Efquimaux, more refembling the European whitenefs, than the Indian red. Upon a caretul attention then, to the colors and cuftoms of the original inhabitants of America, the phenomena feem to confirm the gexeral connection which has taken place between climate and color, in the various parts of the other hemifphere.

I his part of the natura! hifory of man, feems to be but verv imperfeetly anderftood. The grat dificulty that attonds it, is the want of ancient and accurate accounts. Yt does indeed feem to be pretty well determined, that the color of the white man is eafily, and foon changed, to a dark complexion : And that the color of the Indian is changeable, into a lighter complexinn. But no relations which I have feen afiord the fame informatios, refpecing the changes of the African black. Nor can I find ariy phenomena or accounts which ferve to afcestain the matter, and put it out of all doub: whether there has been any change in the color of the negrocs, which have becn brought intn any part of America. Nor is it ccrtain that any fuch appa. rent alteration of the negro color, ought upon any hypothefis to have been expected, in the courfe of four or five generations. And yet, unil fome of thefe facts thall be afcertained, we can hardly expect thet the laws 


\section{APPENDIX.}

mature which apply to this fubject, will be under hood. Impatient of the fatigue of inquiry, collekting and compaing phenomena, tome philofo. phers, with great precipitation, have pretended to decide it by fyftem. To folve all difficulties it has been declared by forne, that there are different creations, and races of men: That the white man is one kind, the negro another, and the Indian a third, \&c. The bulnefs ol making fytems lor nature, has feldom anfwered any othcr purpole, than to dilcover the prefumption of thole, who have made them. It has proved fo in this cafe. If there had been as inany local creations as there are individuals, this would not affoid us any information, or erable us to advance one flep, towards a folution of the problem refpecting the colors of different men. Still she inquiries would remain, what is the feat of color in thefe thfferent men ? Why do the ray's of light appear of fuch different colors, upon the fkirs of the one, and the other ? Why does one color appear moft com. mon in a hot, and another color prevail the molt in a cold climste ? And how is the change of color produced by marriage and mixture? Inllead of a mufing ourleives with theories that are attended with no evidence, and can be of no ufe, what is wanted in this fubjeft, is careful and accurate obfer vations. Thefe will indeed recuire a long courfe of time, and abilities very different from thofe, which decide by metaphyfical difputes and fpeculations. But it is the only method, in which we have any realon to expect our knowledge of this fubject will be promoted.

\section{aranarana}

\section{No. VI.}

\section{GARRANGULA'S SPEECH :}

\section{A Specincn of Indian policy, eloquence, and manners. СНАг。 IX. P. 275 .}

IN the year 1684 , De la Barre, governor of Canada, marched into the Indian country, with an army of feventecn hundred men. His object was to deltroy the five nations. Sicknels and tamine wafted his army, and he withed to conclude the campaign with a treaty of peace. To effect his purpofe, he made a fpeech to the Indians, in which he informed them that he came into their country, with no other view than to make peace : that his mafter was offended with their former conduet, but would forgive them, if they would obferve the terms that he had prefcribed; biat if they would not fubinit to his prefcriptions, lie had orders to declare war againft them, to burn their calles, and put them all to death.

Garrangula, ar, Onondago Sachem, heard thefe threats with contempt. He knew the diftrffed ftate of the French army, and that it was wholly cut of their power to execute their defigns. He walked five or fix times round the circle, and then anfwcred the French governor, who fat in an elbow chair, furrounded by his offeers, in the followigg manner.

"YONNONDIO, *

"I honor you, and the warriors that are wish me likewife hono: s you. Your interpreter has finilhed your fpeech; I now begin mine. - My words make hafte to reach your ears; hearken to them.

* Yonnondio was the name, by which the Indians always addrefted the guvernor of Canada; Curlear was their pluafe, when fpcaking to the gov. crnor of New York. 
- Yonnondio, you muft have believed, when you left Quebec, that the - fun had burnt up all the forefts, which render our country inaccerlible 10 - the French, or that the lakes had fo far oveifl swn the banks, that they" " had furrounded our caftles, and that. it was impuflible for us 10 get out of them. Yes, Yonnondio, furely you mult have dreamt fo, and the curiofity of feeing fo great a wonder, has brought you fo far. Now you o are undeceived, fince that $I$ and the warriors bere prefent. are come to afture you, that the Senecas. Cayugas, Onondagas. Oneydoes, and Mo: - hawks, are yet alise. I thank you in their nane, for bringing back into their country the calumet, which your predeccitor receivid from their - lonas. It was hapoy for you; that you left under gosund that muidur- irg hatchet that has been fo often died in the biond of the French. Hear, - Yonnondio, I do not fleep, I have inveyes open, and the fun, whicli en- lightens me, difcovers 10 me a great capiain ar the h. ad of a company of

- Coldiers. who fpeaks as if he was oreaming. Hc fays, that he only came - to the lake to fmoke on the great calumet with the Onondagas. But - Garrang ila fays, chat ha fees the contrarr. that it was to krock lhem or - the head, if fickneis had rot weakened the arms of the Ficroch.

-I fee Yonnondin raving in a camp of fick mev, whole lives the sicat - Spirit has faved, bu wetliting this ficknets on them. Hcar. Youmnnrion, c our women had their clubs: on children and oid men hacl caprich their - bous and arrows iou, he hrar of you camp. if onar warlones had uest

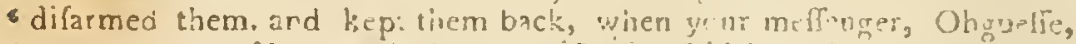
- came to our caftes. It is dome unt a rave faid it. Hear, Yomoncio, se plundered none of th $\$$ e che but thufe that cariec guss. powder,

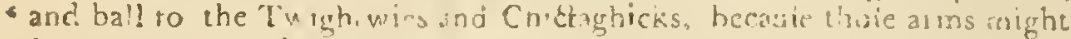
- have colt us our lives Horcin wer wliow the exmple of for Jetuiss, who ftave alt the hegs of rum hrougt t to nur caliles. lett the drunkin ln- dians thould knock them on the head. Our warriors have wot buaver cenough to pay for all thele arms, hat th: have taken, and our old men e are not airaid of the war. This beit preferves my weros.

- We carricd the Euglith into our lakes, to trade there with the Uiawn" was and Quaroghies, as the Sdironriacks broughe the French : o sur caí- tles, to carry on a trade, which the Englifh Lav is theirs. IVe are born 6 free; we neither depend nn Yurnordiu nor Corlear.

- We may go where we pieale. and carr! with us what we plea?e; if - your ailies be your flaves, ule them as fuch, command them to reccive - no other but your people. This belt preferves my words.

- We knncked the Twightwies and Chiotarkicks on lic hend, hecaure - they had cut down the uces of pcace, which were the limits of our coun- try. They have hunted beavers on our lanka; they have acted contrary - tn the cuforrs of all Indians; for they left none of the beavers a!we, they - killed betio male and female. They brought the Saranas into the coun" try, to take part with them, after they had concerted ill defigns againft "us. We have done lefs than cirlier the Englith or French, that have u-

- floped the lands of fo many ludian nations, and chaled them from - their own councrv. This belt preferves mi words.

- Hear. Yonnorkios, what I fay, is the voice of all the five nations; hear - what they anfwer.; npen your ears to what they focak. The aeneces, - Cayugas. Orondagas, Oneydoes, and Mohawks, fay that when they bi"ricd the hatchet at Cadaracqui, (in the prelence of your predeceffor) in the - middle of the fort; they planted the tree of peace in the lame place, to - be there carefully preferved, that, in place of a retreat for loldiers, thas cfort might be a rendezvous for merchants; that in place of arms and ats. 0 anunition of war, beavers and merchandize fhould unly ester these. 


\section{APPENDIX.}

'Hear, Yonnondie, take care fur the futurc, that fo great a number of - foldiers as appear there, do not choke the tice ol peace, planted in fo ¿ fmall a fort. It will he a greas !ofs, if after it had fo eafily taken root, you thould flup its grnwth, and preverit is covering your country and ous withitshon thes. I effure ynu, in the name of the five nations, - ehat our warriors inail dance to the calumet of peace under its leavcs, - and fiall renain quiet on the ir inatts, and llall nuer dig up the hatchet, - till cheir brother Yonnondin or Corlcar Thall either jointly or feparately - endeavor to atlack the countrv. which the areat Spirit has given to our anceftors. This b-lt pieferves my words, and this other, the authority - whicls the five nations have given ine.

Garrangula tien addrzlied . M it to Mnnfienr La Main, the interpreter: - Take courage, faid he, 'Olgurefle, you have fpirit, freak, explain my - words, forget nothing, iell ali your bretzen and lrieids, fay to Yonnon- dio, your governor, by the month of Garrangula. who loves yom, and - defires you to accept of inis piefent of beaves, and take part with me in - my feaft, to which I invite you. This prefent of bcaver is fent zo Yon: "nondio, on the part of the five nations."

\section{n000000000}

\section{No. VII.}

Wonument of Lord Vifcount Howe, in Wefminfter Abber: CHAP. XII. P. 406 .

TiIS monument contains a figure of the genius of the province of Mafiaciuteis Bay, in a inournful ponure, lamening the fa!l of this hero, and the famity arms ornamented with military trophies. Beleath is the followiug inferiptiun, in large characters:

The Piovince of ilaffachufetts Bay, in New England, by an order of tl: = Great aud General Court, bearing date, February 1ft, 2759 , canfed this monument to be eredted to the memoty of Gcorge, Lord Vifcount Howe, Brigar'ier Gencial of his Majeny's furces in North America, who was Dais Jul; $6: h, 3758$, on his march to Ticonderoga, in the $34^{\circ} \mathrm{h}$ ycar of his age; in teftimony of the fenfe they had of his fervices and mulicaty vistues, and of the affcetion their officers and foldiers bore to his command.

He lived refpected and beloved; the public regretted his lofs; to hi:s Samily it is irreparable.

\section{Weftminfter Abbey and its Curicliics, p. 95.}

\section{wanaragara}

\section{No. VIIT.}

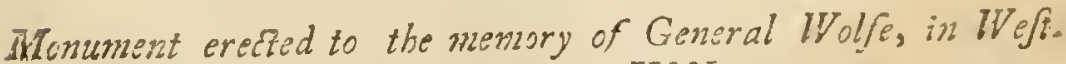
minfter Abbey. CHAP. XIII. P. 423 .

THE lubjedt is the tragic ftory of the General's death in the very momen: of victory. He is reprefented in the laft agouies of expiring heroifm, with his hand clofing the wound whicin the ball that killcr him

; Smith's Hilt. New York; Frlf edition, p. 50. 
had made in his breaft, and falling into the arms of a grenadier, who catches and endeavours to fupport him on his haunches, while with one hand he holds his feeble arm, and with the other points to glory, in the form of an angel in the clouds, holding forth a wreath ready to crawn him. On the pyramid, in relief, is the faithful Highland fergeant who attended him, in whofe countenance the lig fornow at the mournlul fight of lyis dying mafter is fo powerfully and pathesicaily es:prefled, that the molt incenfible human being cannot look upon him, willout, in fone fort, thaso ing in his grief.

This monument does equal honor to the artift who defigned it, and the fculptor by whom it was execured. Every part is malterly. The lious that reit upon the bafe, and the wolve's heads that ornament the flanks, are animated; but above all, the alt-relief that dezorates the front, and repreierts the landing at Quebec, convey's fuch a lively view of the hor id rocks and precioices which the foldicrs had to climb, and the failors to furmount with the canron, before they could approach to atiacl the eneany, that nne cannot tell which malt to admire, the bravery of the troops, who could conquer under luch difficulties. or the art of the fculpior, who could make a reprefentation fo ttriking. Tot incription carries no marks of oftcuation, bue finsply records the lacts in the following words:

To the memory of J AMES WOLEE, Niajor General and commander in chref of the Britith land forces on an expedition again? Quebec; who, after furmounting, by ability and valor, al: obftacles of art and nature, was flain in the moment of riftory, nn the 13 il of september, 1759 :

The King and Parliament of Great brttain dedicate this moument.

Wefminter Aboey and its Curiolitis, p. $5 \%$

\section{6}

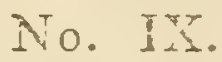

\section{Infeription on the tomb of the Marquis de Montcalin, at Prebec.} Снар. XHI. P. 423 .

Tranßation of a letter from M. Hougainville, Nember of the Academy o: Sciences, to the Righi Hun. Wili \& . Piti.

S IR,

THE honors paid duing your minifry, to the memory of $\mathrm{Mr}$. Wolfe, give me room to hope, that you wiil not difapprove of the grateful cfforts made by the French troops to perpetuate the memory of the Mar quis de Miontcalm. The cosple of that General, who was hnnored with the regret of your nation is buried at Queocc. I have the honor to fend you an epitaph, which the Academy ot hiscriptions and Beiles Letures have wrote for him; and I would leg ine favor of you, far, tn read it over, and if there be nothing improper in it. to procure me a permiftun to fend it to Quebec, engraved in marble, to be put over the Miarquis de Miontcalm's tomb. If this permifrion thould be granted, may I p:elume, fir, so intreat the howor of a line to aequaint nes with it, and at the fame time in fend me a palfport, that the engraved marble may be received on board an Englifh veffel, and that Mr. Murray, Goverwor of Quebec, may give leave to have it put up in the Uifuline Church. है I afk pardon, fir, for ta. sing off your attention, even for a moment, fiom your important concerns: but to endeavor to immontalize great men asd isultrious citizens, is to do bunor to you. I am ixc. BOUGAISVILIE. Deris, March $25^{\text {th }} 17 \varepsilon_{1}$. 


\section{APPENDTX.}

Sita,

\section{MR. PITT'S ANSWER.}

IT is a rail fatisfaction to me to fend you the King's confent on fuch an interefting fubject, as the very handfome cpitaph drawn by the Acaciemy of Infcriptions at Paris, for the Marquis de Montcalm, which is defired to be fent to Quebec, engraved on marble, to be fet up on the tomb of that illufrious warrior. The noble fentiments expreffed in the defire to pay this tribute to the memory of their General, by the French troops who rerved in Canada, and who faw him fall at their head, in a manner worthy of him, and worthy of them, caunot be too much applauded.

I Thail take pleafure, fir, in facilitating a defign fo full of refpeEt to the deceafed; and as foon as I am informed of the meafures taken fo: $\mathrm{cm}$ barking the marble, I thall immediately grant the palfport you defirc, and fend orders to the Goveruor of Canada for its reception.

As to the relt, be affured, fir, that I have a jult fenfe of the obliging things faid to me in the letter with which you horored me, and that 1 thirik it a fingular happinefs to have an opportunity to exprefs thofe fentimens of dillinguifhed efteem and confideration with which I have tise hosor to be, \&rc.

April 10,1761 .

THE INSCRIPTION IS AS FOLLOWS.

HIC JACET

Utroque in orbe æternum viEturus,

LUDOVICUS JOAEPHUS DE MONTCALM GOZON: Marchio Santti Verani Baro Gabriaci

Ordiris Saneti Ludovici commendator.

Legaius Generalis exercitaum Gallicorum:

Erregius et cives et miles ;

Nullius rei appetens, praterquam veræ laudis,

Ingenio felici et litteris exculto

Omres militiz gradus per continua decora emenfus,

Omnium belli artiun, temporum, difcriminum gnarus.

In Italia, in Bohemia, in Germania dux indufrius.

Mandata fibi its femper gerens tit majoribus par haberetur.

Jam clarus periculis

Ad tutandam Canadenicm provinciam milfus,

Parva militum manu hofium copias uor femel repulit.

Propugatcula cepit viris armifgue inftruCtilima,

Algoris, ined: vigilarum, laboris patiers,

Suis unice profpiciens, immemor fui ;

Hollis acer, viftor manfuctus.

Fortunam virtute. virium iunpiam peritia et celeritate compenfavit. Ix niness colonix larum et confri in et manu per quadriennium fuftinuit,

Taudem ingenicm exercituin duce flrenuo et audaci

Clafernque omui bellorun moli gravem, Muleiflici prudentia diu ludificatus,

$\mathrm{Vi}$ pertractus ad dimicandum

In prima acie, in primo conflitu vulncratus,

Religione, quam femper coluerat innitens,

Magno fuorum dcfiderio, ncc fine hoftium maerore extinctus eff

Die XIV Scptembr, A. D. MDCCLIX. xtat is XVIII.

Mortales optimi dacis exuvias in excavata humo,

2uam globus bellicus decidens diffilienfque defoderts,

Galli lugentes depofuerune,

Et generola holt:um fidei commcndarent. 


\section{TRAVSLATION.}

HERE LIETH,

In either bemifphere to live forever,

LEWIS JOSEPH DE MONTCALM GOZON,

Marquis of St. Veran, Baron of Gubriac,

Commendatnry ot the Order of St. Lewis,

Licutenane Gcneral of the French Army,

Not lefs an excellent citizen than foldier;

Who knew no defire but that of truc glory:

Iappy in a natural genius improved by literature; . Having gone throuch the leveral theps of military honors;

With ininterrupted luftre,

Skilled in all the arts of War,

The juneture of times, and the erifss of dangers,

In Italy, in Rohemia, in Germany,

An iudefatigable Gencral,

He fo difcharged his imporiant trufts

That he feened always equal to ftill greater,

At length grown bright with perils,

Sent to fecurc the Province of Canada,

Witl a handful of men

He more than once repulfed the enemy's forces;

And made him! elf malter of their Forts

Replete with Troops and Ammunition.

inured to cold, hunger, watchings and labors,

Unmindful of bimfelf,

He had no fentation but for his foldiers,

An cneiny with the fiercelt impetuofity;

A victor with the tenderct humanity,

Adverfe fortune he compenfated with valor,

The want of Itrength with $\mathrm{kill}$ and aetivity;

And, with his counfel and lupport,

For four years protraeted the impending fate of the colony.

Having with various artifices

Eong baffled a great army,

Headed by an cxpert and intrcpid commander,

And a Flect furnithed with all warlike thores,

Compelied at length to an erigagement,

IIe fell, in the frit rank, in the list onfet,

Warm with thofe hopes of Religion which he had always cheriftied,

To the inexprelibie lufs of his own army,

And not without the regret of the enemy's,

XIV. Scptember, A D MDCCLIX. of his agc XLVIII.

His weepiren countrymen

Depofited the remains of their excellont General In a Grave

Which a falien Bumb in burlting had excavated for him, Recomnending then to the genercus faith of their enemics. Fill's Life, Vol. II. p. $32 i$.

END OE 'THE FIRST VOLÜME' 


\section{INDEX.}

ooos

A.

Abercrombie general, takes command of the Englifh tronps, 378. Attempts io take liconderog?, and is repulfed with great Mughter, $40_{4}-42$. Remarks on his mea'uris. $412,4 ! 3$

Sidario, his piricy and ineafures, 282,283 .

Agriculture, difficurtes attending it in the colonics, $465-468$.

Aix la Chapelle, peace of. 38 .

Algonquins, their countr, 564 .

Ampergt general, lakes Loub urg, 404. Proceeds with his army, to Albiz:

riy, 417. l'akes nofieltion of ricondernga and Crown Point, 425. Attempis to proceed in $\mathrm{C}_{2}$ nada, 434. Prepares for the next campaign, 435 .

Plan for the reduction of Canada, 443. Arrives at Orwego, 444. Proceesis clown the river St. Cawrence, and lands on the inland of Montreal, $4+4.445$. Effects the conqueft of Canada, $45^{\circ}$.

Animuls, Amcrican and European compared, $13^{\circ}$.

B.

Barre M. aims to deltroy the five nations, 273. His army reduced to grcat diffrels, 274. Makes a fpeech to and treaty with the Indians, 27. Biar, account of, 100 .

Eicaver, riatural hiltory of, 11 a-128.

Bee, butnhle and honey bce indigenous to the country, 256 .

Buds, seneral account of, 134. Of paffage, 135. Singing, 143. Wates fowl. 1 4.t.

Bradduck general, appointed commandẹr of the troops in the Englith colo. me's, 349. Defeated and Main at Monongehala, 350--.352.

Brudircet colonel, defears the Indians at Odonclago river, 373. Takes C.didaquil , or fort Frontenac, $413-415$.

Burnet governor, builds a fort at Olwego, 328.

C.

Callieres $M$. his plan to lubdue the province of New York, and the Indians ot the five nations, 289,290 . Makes a treaty of peace with the five natiins, 303

Canuda, dilcusvered and explored by Cartier, 252. Explored and feuled by Champlain, $258-260$. Reduced by the Englifi. 261. Reftored to France, 262. Reduced to great diftefs, 266. 285. Fit it a!temot of the Engith coloniés to reduce it, 295-299. Second attempt. 308-313. Finird attempt, $318-3_{2} 4$. Surrendeted to the Britith crowu and governinent, $45^{\circ}$. Coufirmed to the Britih governmeut by the treaty of Paris: Feb. 10, 1763451.

Canfeau thiken and piundered by the French, 333 .

Cartier 7 imes, enters the mouth of Canada river, 252 . Gives it the name cf Si. Lawrence. proceeds as far as Hochelnga and calls it Montrca!. 252. Pioceedings at that place, $253-25 \%$.

Cat zuild. defcriprion o:, 105 .

Catamourt, account of, $10_{4}$.

Champlain lake. account of 50 . Difcovered and nartied, 260 .

Chumplain Samuel, fails up the river Si. Lawrence, 258 . Found the cityo

Quebec, 259 Explores the lakes Champlain and St. Sacrament, 260. Engagemeu with the Iroquoile, 260. Surrenders Quebec so the Engitis,

y०ג. I. P 3


26r. Refumes the government of the colony, 262. Death and charazter, 262.

Charlegiozun or Numb'r Furs, fort at, attacked by the French, and defended by Srevens. 458 .

Chine e culioms and manncrs, fimilar to thofe of the Indians of Peru, 230. Clerg), , late of in the Britith colonies, $456-458$.

Climale. cemperature of, $52-58$. Change of, $70-80$. In Europe, $473-$ 478

Colinies Engligh, their diftrefled Atate, 308. Great advantages from peace, $33^{2}$

Colors of Men, difiertation on, $493-503$.

Columibus, difcovers America, 254.

Conlcar, faves the French and Indian army, $26 \%$.

Councelles, invares the Mohawks, 267. Builds forts at Sorel, Chambly, and Cadaraqui. $26 \mathrm{~g}$.

Crown Point, a fort erected at by the French, 329. Advantagcs refulting to Canada Irom this meafure; 329 . Pafive behavior of the Englifh cola nies, 331 . Taken pofteffion of by general Amherft, 425 .

Cultivation, cfiects of, 75 .

D.

Deerfueld, deftroyed bj the French and Induans, 305 , Repels their attacks, $3^{2} 3$.

Denonille, M. governor of Canada, 275. Plan of operations, 276. Marches into the Indian country, 278. Defeated by the Senecas, 278 . Makes peace with the Indians, 281 .

Diefau baron, commands the French troops in Canada, 360 . Defeated and taken prifoner, 361 . Remarks on his condu\&, 366 .

Dengan governor of New York, oppofes the French governors and influence, and alfits the Indiaus, $273 \cdot 274 \cdot 276 \cdot 279 \cdot 280.288$.

Dutch colony, on Hudfoh's river, cuitivate peace and commerce with the Indians, 270. Surrendered to the Englith, 270 .

E.

Esporation, from the earth, 76 . From the trees, 89 ,

Edward fort, built by general Lyman, 359 .

Education, fiate of in the colonies, $\Delta \sigma_{3}$.

Ermine, deficrited, 1:1.

Efquimaux, iheir appearance and defcent, 233.

Expcditions for the reduction of Canada, firtt, 295-299. Second, $308-$ 313. Third, 318-324. Fourch, $420-424.443 \cdot 45 \bullet$.

\section{F.}

Fifh, account of, $1455^{\circ}$ Migration, 147 . Immcnle numbers, 349.

Farefs. immenfe s:

Fo/fl fhells, noted, ${ }_{5} \mathrm{O}^{\circ}$

Fox, account of, $\mathrm{roz}_{3}$.

Frogs, found in the earth at Windfor, Caftleton, and Onion river, $1,5=$ 153. At Burlington, $479-482$.

Fontenac count, fends an arniy ayainf Nicw Hampthire, and another agairn New York, 291. Dciends Quebcc, 297, 298. Expidition againt the Mobawks, 300 .

G.

Carranguli, fpeec! to De Earre, 275. ro3. 
infeng, in great plenty, 85 . Goofe zuild, account of, 135.

IS.

Hare, defcribed, 110.

Ilaviland colonel, procecds from Crown Point to Canada, and arrives at the river St. Lawrence oppofite to Montreal, 449.

Heat, of the atmofphere, 58 . Of the earth, 73 . Of the trecs, 94 .

Fijerical writers, nnted, 460, 466 .

Hocheioga, vifited by Cartier, 252. Called Mnntreal, 253. State of the Indians, and proceedings of Cartier at that village, $353-256$.

Hoofic. Fort at, taken by the French, $33^{6}$.

Holititics, between the Englifn colonies and the five nations, 272. Treaty oi perce and conmerce, $\_72$.

Hincue Lord, flain at Ticonderoura, 406. Monumental infcription, 505.

HInnter $\mathrm{Mr}$. governor of New York, his meafures of policy, $3 \mathrm{I}_{3}$.

Hutons, their country, 264 .

I.

Indians, the original inhabitants, 60 . Thcir appearance and countcrance, :63. Employmeris ard inechuds of procuriug fubliftence, 162. State of Iociety, 164 . Nature, form, ftrength, finefs, and eftect of their civit Government, $16.5-170$. Syltem of war, 170. Manuer in v'lich it was carried on, 17:. Treatment of prifoncrs, 173-177. Their fyftcin of war fuited to their ftate of fociety, 177. Indian education, 179. Cufcoms and manners ; gravity of appearance, 180 . Treatment it women, 58. Drefs, 183. Ialene!s, 184. Dirtinels, 184. Gaming, 185. Songs, 185: Dancing, 186. Beard, 188 Drunkennels, 190. Crucl-. iy, 19 \%. Healih, activicy, and bodily vigor, 195. Firmers and fortilude of mina, 197. Political talents and virtues, 199. Pruduce, s.00. Kionucrec, 201. Hofpitalicv, 203. Honetty, 205. Morality, 26.5. Incelicctual improvenents, 206 . Infcriptions, $2 \%$. Ideas of the beity' se 8. Of the innortality of the foul, 209. Virtues, 210, Ausimments in the acts, 21 1 . Population, the thate ot, 215 . Caules of its deficiency, $2: 5-222$. Aver fe to all improvements, 222. Origio $225-236$. Antiquity, efimated by their cxtent, 237; by their langtiages, 239; by their arts, 241. Progrels of fociety, 242 . Its afpect in Mexico, 243 ; sis Peru, 2:5. Tendency to diffolution, 240 . Kravage the eafteru pro. vinces: 303 .

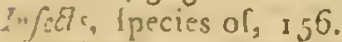

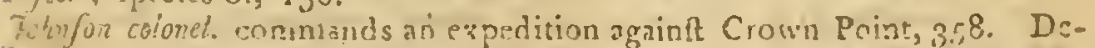
fuats the French trops under the baron Dickkau, $363-306$. R=ruarks on his condun, 367 . Builds fort Willian Henry, 368 . Rewar. ded and promoted by the Rritifh goverument, 390. Deteas the French and captures the fort at Niagara, $435-437$. Mbilities and addref's in managing : he Inóiani, $437,436$.

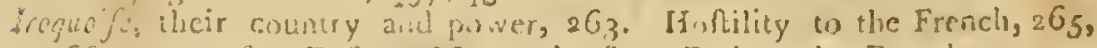
266. 275.378 . Bzthoy ifoutreal, 28 . Redice the Freach is great

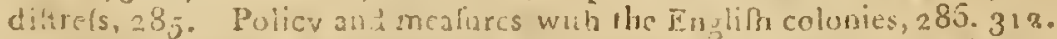
Thair fentiments on the expedition agauist $C$ nada, 299 . Five of their chicfs make a royage to England, 3I5. Make a fpeech to Queen sume, 316, 317. Unfavo:able fentiments of the Englith power and policy, 62.3. Foined by a fixth nation, 327 . Their obiervatiens on the conduc? of the kar!ih, $34^{5} 5$. 
I.

Law, courts of in the Britin culonies, $45^{8}, 459$.

Life regetatle, powers of in America, 97. Animal, powers of, 159 .

Lcudon lord, takes the command of the Englifh troops in the colonies, 371 . Ancedotes of. 379. Embarks on an expedition againft Louifbourg, 381 .

Returins to $\mathrm{New}$ Yoik, and erigages in a concelt with the province of Maffachufetts, 400,401 . Returns to England, 403 .

M.

Mognetic obfervations, an account of, 474 .

Malayans, extent of their navigation and lettlements, 232.

1:2n, not an animal of climate, 236 .

Martin, def́cribed, 109 .

Medical pant of frience, fate of in the Britith colonies, $459,460$.

Memphrcritagog like, account oi, 52 .

Mink, defcribed, I 22 .

Mohau'ks, attacked by the Freach, 267.301. Roan and eat the bodies of their enemies, 302 .

Monckion coloriel, commands an cxpedition in Nova Scotia, $852-354$.

Montcalin, takes Orvicgo, 375. Violates the articles of caplutalum, 376. Meafures with the Indians, 382 . Takes fort William Henry, $3 s_{5}-391$. Barbarous violation of the capitulation and maflacie of lise garrifon, 39:-398. Reflettions on Monicalm's conduct, 393-400. Defeats Abercrombie at T'iconderoga, 412. - Defealed by Wolfé, and dies ạ Qucbec, 423 Monumental inlcription. 506 .

Montreal, ramed by Cartier," 253 Settled by the French, 260. Deftroy. "efl by the Indians; 284 . Suriendered to general Amherlt, $45^{\circ}$.

Moofe, recount of, 99 .

Mountains, their direction, 26. Altitude, 27. Caverns, eg. Origin of - Spritugs anid rivers, "3́t.

Nurray general, fuffers much with his army ar Quebec, 445. Defeated by the French, 446. Reileved by the Bruifh Heet, 447. Proceeds up the river St. Lawrence, and lands on the inand of Montrcal, $447-148$. Wufkral, deferibed, 122.

N.

Niggara, fortified by the French, 269 . Taken by general Johnfon, $435^{\circ}$ Nicholfon, commands an almy againft Canada, $3 \circ 9$. Puts an end to the campaign, 911. Reduces Port Royal, 318. Uiges another expedition againf Canada, 318. Commands the culony troops, 320, Difibande his army, $32 z$.

O.

Ofuego fort, built by governor Burnet, 328. Foridsed by general Shirleyg

357. Taken by Monicalm, 375 .

Gilcr, account of, 1 is.

P.

Barter colonel, defeated by the French and Indians: 383 .

Phips William, commanus a fiect and army agrinlt Quebce, 2970

Pickerel, defcribed, $11^{8 .}$

Pigeons, immenie numbers, $336-133$.

fill Ifilliam, appointed fecretary of ilate to conduR the affairs of the Bri-

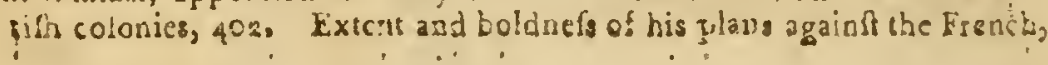


$418-420$. Judgment and wifdom in the appointment of generals, 138 . Policy and views of the court of France, 327.343 .

Politicol opinions in the colonies, 468,469 .

Population, fonall among the Indians, 215. Caules of its deficiency, $215-$ $22 \%$. In the colonies: 464 .

Porcupine, account of, 107 .

Priefs or miftionaries, their attempts and influence amongthe Indians, 278 . Puinam major, difcover the defigns of the euemy againft fort Willang 'Henry, $284,285$.

Q.

Quadrupeds, account of, 98 . The enumeration imperfect, 123. Origin. 125. Migration, 127. Species, 128. Mágnitude, 129. Temper and dilpofition, 131. Multiplying power, 132 .

Quebec, founded by Champlain, 259. Taken by the Englith, 261. Reftored to the French, 262. Altacked by the Englinh, 298. Taken by Wolfe, 423 .

Du Quefre fort, built by the French, 340. Abandoned by the Fitench and taken by the Englioh, $4^{17}$.

Rabbit, defcribed, 110 .

R.

Kiacoon, account of, 106.

Rain, quantity of, 62 .

Fivers, account of, 39. Channels, 44 . Form intervales, 44. EffeEts on the rocks, 47.

Rockingham, Indian infcriptions at, 207.

Rogers major, deftroys the Indian village at St. Francois, $128-4336$

Ry/wick, peace of, 308 .

S.

Salmon ' alls, fort at deftroyed by the French, 29 .

Salmon Trout, account of, 148 .

Scheneftady, deftroyed by the French and Indians, 292, 293.

Schugler major, exerions at Albany and Scheneetady, 293. Succels againfr. the French fetclemerits on the river Sorel, 299. Afrills the Mohawks。 301. Gives information of the enemy's defigns againft Deerfield, 304: Influence with the Indians, 325, 'Makes a voyage to Englard with five Indian chiefs, $3^{1} .5$. Procures the Indizns to affift in an expeditiou a- . gainft Canada, 320 .

Srience, ttate of in the colonies, 461,462 .

Serpents, [pecies, 254 . Fafcinating power, 255. Differtation on, 483493.

Shigley, Mr. plans an expedition againnt Cape Breton, 333. Againft Quebec, 335. Againft Crown 'Point, 336. Commithoner at Parts, 339. Exertions in favor of the Englifh colonies, 348,349 . Commander in chief of the Englith troops in North America, 354. Proced: ings at Ofwego, 3.55-358. Sertles the plan of operatious for the next rampaign, $36 \mathrm{~g}$. Superceded in the command, and retircs from the fcro vice, 372 .

Skunk, account of, 108 .

Snow, obfervalions and experiments on, $64-67$. Decreafe of, 77 .

Snow bird, deícribed, 135 :

surings ard rivers, their orituis and formation, $31-3\}$. 
Squirrels account of, 112.

Stancuix fort, erected at the carrying place at Oneydz, 412 .

Stevens captain, defends the fort'at Number 'Four, 337.

Scuallows, their different kinds, 38 . Place of refidence in winter, $140-1$

143. Obferved at Danby, 140. At Middlebury, 1 1 $^{\circ}$. At Bridpurt,

143. At Hubbardion, 142,

T.

Tatars, refemble the American Indians in their features, 227 . Ia their cuftoms, $2.27-230$.

Trees, their kinds, 81. Magnitude, 87. Number. 88. Age, 89. Evapo. ration, 90. Emilion of air, 92. Heat, 93. Effects, 96.

Trois $R$ vicris, fettled by the French, 265.

Ticonderoga, fort at, built by the French, 350 . Atracked by Abercrombie, 40.1. Evacuated by the Frencli, and taken polfellior of by Amherlt, 425.

$-U$.

Union of the Englith colonies, plan of, propofed at Abany, $344-348 \ldots$

Utrecht, peace of, 325 . Effet on the Indians, $3 \geq 5$.

$\mathrm{V}$.

Vaudrieul $M$. fends an army againt Deerfield, 304 . Mesfures for rhe defence of Canada, 320-322. Takes fort Hulac. 336. 'Gquernor general of Canada, 363. Dittrels and exertions in delence of Canada, 499 $\cdots 412$. Surreriders the whole country to general Amberlt, $150^{\circ}$ Vegetables, efculent, 83. Medicinal, 84.

lermoni, furuation, a1. Boundary lines, 21.1 Quantity of laud, 24 . Soil, $2 j$. Face of the country; \&5.

W.

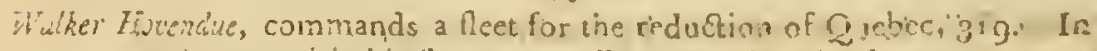
extreme danger with his fleci, $3<2$. RHurns 11 tugland, 322.

Wis, the firt betwecn the Englith and Freich colomins, 28 . Origin of the colonial wars. $152 \cdots 454$. Moral effects, 454.455 . Liffens on taie hiterary and fciensitic character and purfuits of 416 61) wises, 155 .

irafington Gooroe, cominifioned by the governor of Virginia; 341. Defeats $M$. de Jum mitic, 342. Deleated by De Villier, 34 a.

Weafel, defcibcd, 120

Weather, account ol, $6 \%$..69. Change of, 79 .

Wef-river, Indian inímptions at, 207 .

ivilliums 7 old ancculotes of, 306 . .

inina's, their diretion, $59 \cdots \mathrm{E}_{\mathrm{I}}$.

Winflow coloncl, engaged in an expedition in Nova Scotia, 353. Com. mancis an army at fort 1Villiam Heury, 376.

Winihrop foln, commands an army againlt Cauada, 296.

Tïnodchuch, account wf, 108 .

Wulf, account of, 101 .

Ifife gencral, bravery at Louito vire, 424. Dath and conquent of the

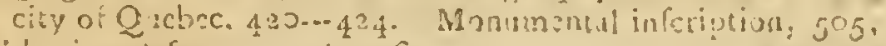

Fusluerine, defrription o:, 166 . 
II a patt of the imprefiron, the following errors were not cortected.

\begin{tabular}{|c|c|c|c|c|}
\hline Page & line & & for & read \\
\hline $20 I$ & 13 & 1 & mildnefs & wildoefs. \\
\hline $\begin{array}{l}337 \\
423\end{array}$ & 23 & & Cendon & Clarendon. \\
\hline $\begin{array}{l}422 \\
427\end{array}$ & 7 & & Sillary & Sillery. \\
\hline 427 & $\begin{array}{r}4 \\
15\end{array}$ & & $\begin{array}{l}\text { Burlemagne } \\
\text { Burlemagne }\end{array}$ & $\begin{array}{l}\text { Burlemaque. } \\
\text { Burlemague }\end{array}$ \\
\hline 433 & $3^{\circ}$ & & radien & radezu. \\
\hline $43^{\circ}$ & 27 & & Venangs & Venango. \\
\hline $\begin{array}{l}430 \\
891\end{array}$ & $\underset{2}{9}$ & & Farguhar & Farquhar. \\
\hline & & & & \\
\hline
\end{tabular}





s. 

IfFIDOX IIIBRARY

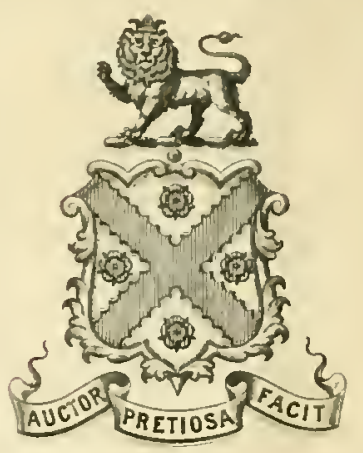

Batrefoft Collection.

Putrolased it IS93. 


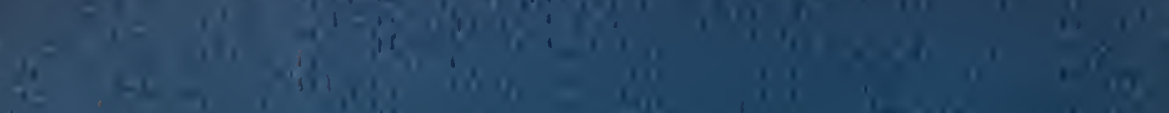

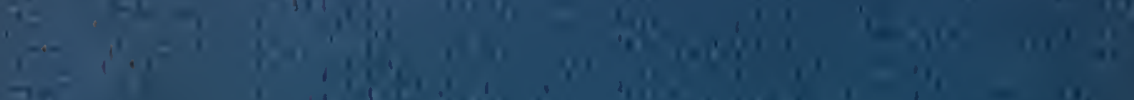

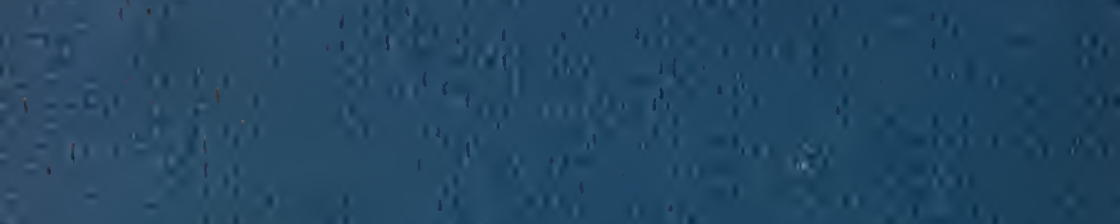

$-i$ $x^{\prime}$

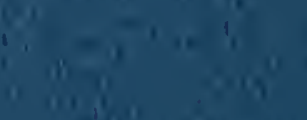

2,198

$\operatorname{lin}^{2}, x^{\prime}$

1410

in

10

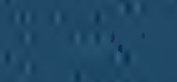

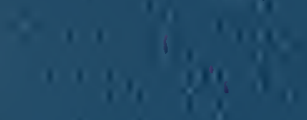

11

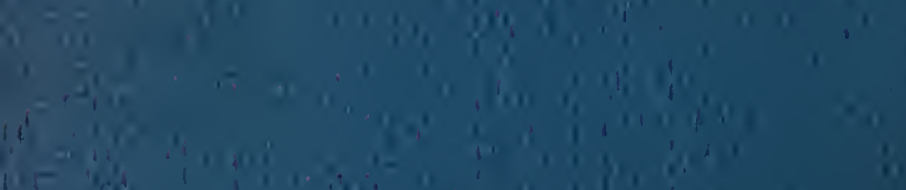

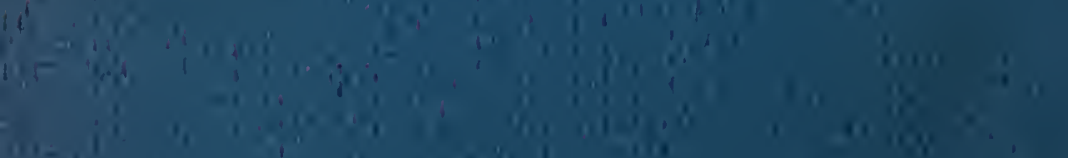

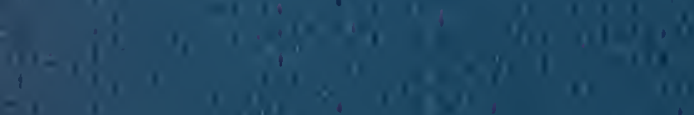

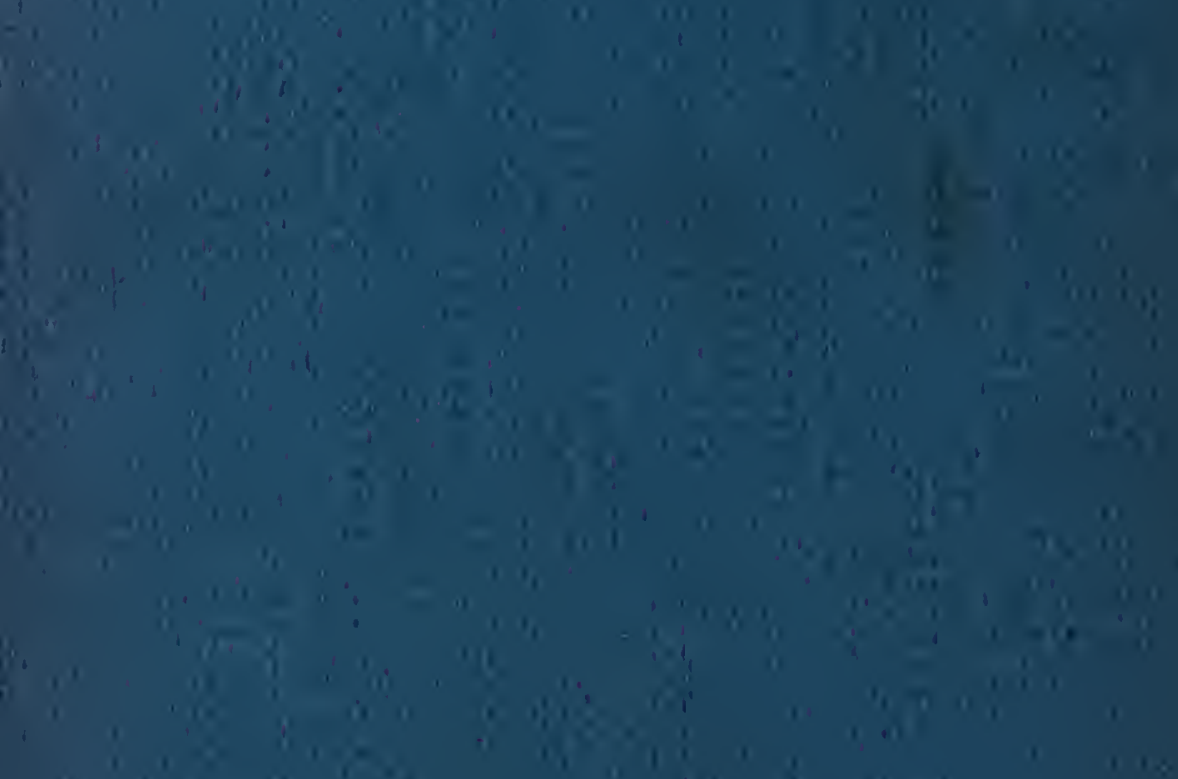

4
4
4
4
4
4

1.

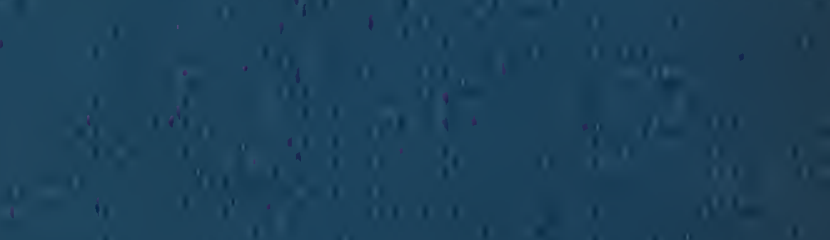

